Florida International University FIU Digital Commons

$1-29-2002$

\title{
Environmental quality monitoring at five golf courses in Miami-Dade County
}

Lorna Bucknor

DOI: $10.25148 /$ etd.FI14051870

Follow this and additional works at: https:// digitalcommons.fiu.edu/etd

Part of the Civil and Environmental Engineering Commons, and the Environmental Sciences Commons

\section{Recommended Citation}

Bucknor, Lorna, "Environmental quality monitoring at five golf courses in Miami-Dade County" (2002). FIU Electronic Theses and Dissertations. 2328.

https://digitalcommons.fiu.edu/etd/2328 


\section{FLORIDA INTERNATIONAL UNIVERSITY}

Miami, Florida

\section{ENVIRONMENTAL QUALITY MONITORING AT FIVE GOLF COURSES IN MIAMI-DADE COUNTY}

A thesis submitted in partial fulfillment of the requirement for the degree of

MASTER OF SCIENCE

in

ENVIRONMENTAL AND URBAN SYSTEMS

by

Lorna Bucknor

2002 
To: Dean Vish Prasad

College of Engineering

This thesis, written by Lorna Bucknor, and entitled Environmental Quality Monitoring at Five Golf Courses in Miami-Dade County, having been approved in respect to style and intellectual content, is referred to you for judgment.

We have read this thesis and recommend that it be approved.

Shonali Laha

Carl Phaffenberger

Berrin Tansel, Major Professor

Date of Defense: January 29, 2002

The thesis of Lorna Bucknor is approved.

Dean Vish Prasad College of Engineering

Dean Douglas Wartzok University Graduate School

Florida International University, 2002 


\section{DEDICATION}

I dedicate this thesis to my family. To my parents for providing at great personal sacrifice the foundation of a good education. To my husband, whose love is the wind beneath my wings. To my sister, and my two dearest friends for their support, motivation and for always, always, 'having my back' and finally, to my twin daughters, Tara and Tiffany, my life's passion. 


\section{ACKNOWLEDGMENTS}

I wish to thank the Miami-Dade County Department of Environmental Resources Management (DERM) and the Florida Department of Agriculture and Consumer Services (FDACS) for sponsoring the study and for allowing me to use the material for my thesis.

Special thanks to the staff of DERM's former Planning and Evaluation Section especially to Julie Baker, for believing in me, supporting me, and facilitating the resources necessary to conduct this research. Thanks especially for her assistance with the graphics herein presented. Thanks to Beth Baughman, not only for her invaluable assistance with data validation, quality assurance and editing, but also for her friendship. To Jorge Mederos for the grueling hours spent assisting me with fieldwork. Special thanks also to Wilbur Mayorga, for his critical editorial contribution and for his confidence in my abilities, his support and direction not only in this endeavor but also in so many others.

Finally thanks to the members of my committee but especially to Dr. Berrin Tansel, my major professor for her support, understanding, patience, and guidance not only for this thesis but also throughout my coursework. 


\author{
ABSTRACT OF THE THESIS \\ ENVIRONMENTAL QUALITY MONITORING AT FIVE GOLF COURSES IN \\ MIAMI-DADE COUNTY \\ by \\ Lorna Bucknor \\ Florida International University, 2002 \\ Miami, Florida \\ Professor Berrin Tansel, Major Professor
}

Five golf courses in Miami-Dade County, Florida participated in a one year monitoring study to investigate the environmental impact of agrichemical turf management activities.

Groundwater, soil, surface water, and sediments were sampled quarterly at the golf courses in 1997. Ground and surface water were sampled for 51 pesticide residues (including arsenic), nitrates, and phosphates. Soil and sediments were sampled for arsenic.

Arsenic was the main contaminant of interest. Seventy-five percent of soil samples exceeded the Florida residential soil cleanup target level (CTL) while thirty-two percent of shallow groundwater samples exceeded the maximum contaminant level (MCL). Five other pesticide residues were detected in groundwater, but only one exceeded the MCL. Pesticide residues were also detected in surface water. Nitrates were found in ground and surface water; twenty-one percent of groundwater samples exceeded the federal health advisory level. 


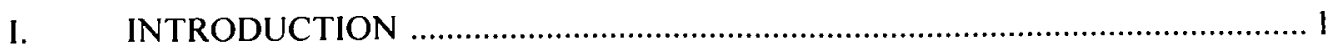

II. PREVIOUS STUDIES...............................................

III. METHODOLOGY

Description of Study Area ........................................................................ 5

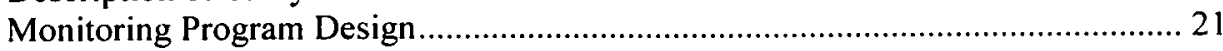

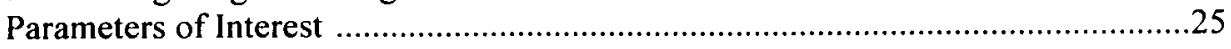

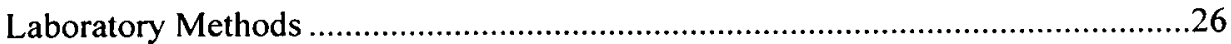

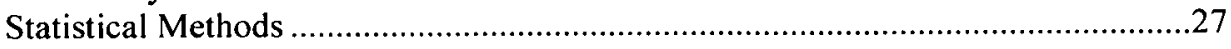

IV. RESULTS AND DISCUSSION

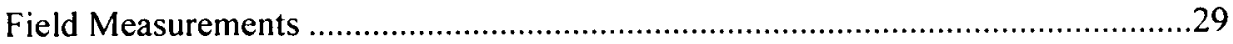

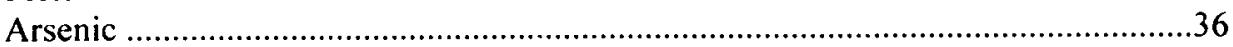

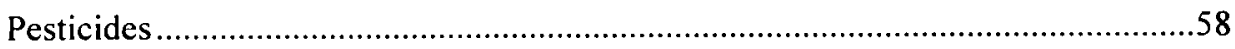

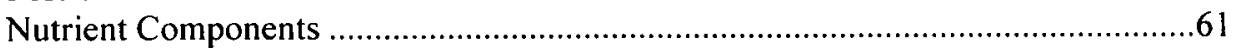

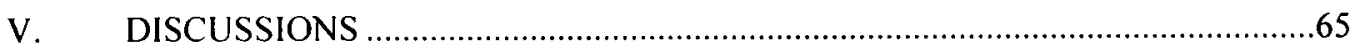

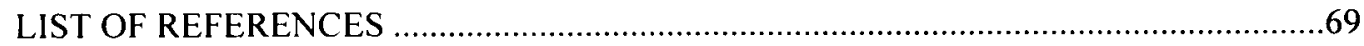

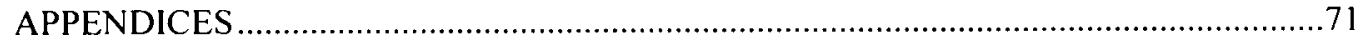




\section{LIST OF TABLES}

TABLE

1. Distribution of Monitoring Wells by Golf Course Area 22

2. Properties of Targeted Pesticides 25

3. Soil Samples Exceeding Criteria $\quad 37$

4. Summary Statistic for Soil Arsenic Concentration 38

5. Summary Statistic for Arsenic Concentration in Shallow Groundwater 40

6. Summary Statistic for Arsenic Concentration in Deep Groundwater 40

7a. Summary Statistic for Arsenic Concentration at All Mix/Load Sites 42

7b. Summary Statistic for Arsenic at Mix/Load Sites at Briar Bay \& Greynolds Park 42

8. Summary Statistics for Arsenic Concentration at Fairway Sites 45

9. Summary Statistics for Arsenic Concentration at Green Sites 48

10. Summary Statistics for Arsenic Concentration at Tee Sites 51

11. Arsenic Concentration in Fertilizer Formulations 56

12. Pesticides Detected in Ground Water 59

13. Pesticides Detected in Surface Water 60

14. Summary Statistics for Nitrates in Groundwater 62

15. Nutrients Level in Golf Course Ponds 64 


\section{LIST OF FIGURES}

FIGURE

PAGE

1. Map of Florida

2. General Groundwater Flow Direction 7

3. Generalized cross-section of the Biscayne Aquifer Underlying $\begin{array}{ll}\text { Miami-Dade County } & 8\end{array}$

4. Map of Palmetto Golf Course 16

5. Map of Briar Bay Golf Course 17

6. Map of Key Biscayne Golf Course 18

7. Map of Greynolds Park Golf Course 19

8. Map of Golf Club of Miami 20

9a-9e. pH, DO, Redox, Salinity and Specific Conductivity from Participating Golf Courses $\quad 32$

10 a-d. Arsenic Concentration at Mix Load Sites 43

11 a-d. Arsenic Concentration at Fairway Sites 46

12 a-d. Arsenic Concentration at Green Sites 49

13 a-b. Arsenic Concentration in Soils at Tee Sites 51

$13 \mathrm{c}$-d. Arsenic Concentration in Groundwater at Tee Sites 52

14 a-b. Arsenic Concentration in Surface Water and Sediments 55

15. Arsenic Species Distribution in Groundwater 57

16. Nitrate Concentration in Groundwater 63 


\section{LIST OF ABREVIATIONS}

\begin{tabular}{|c|c|}
\hline BDL & Below Detection Limit \\
\hline bls & below land surface \\
\hline DERM & $\begin{array}{l}\text { Miami-Dade County Department of Environmental Resources } \\
\text { Management }\end{array}$ \\
\hline FDOH & Florida Department of Health \\
\hline ENP & Everglades National Park \\
\hline EPA & Environmental Protection Agency \\
\hline FDACS & Florida Department of Agriculture and Consumer Services \\
\hline FDEP & Florida Department of Environmental Protection \\
\hline HAL & Health Advisory Level \\
\hline LC50 & Lethal Concentration $50 \%$ \\
\hline MCL & Maximum Contaminant Level \\
\hline MDL & Method Detection Limit \\
\hline MSMA & Monosoduim Methanearsonate \\
\hline $\mathrm{mg} / \mathrm{kg}$ & milligrams per kilogram \\
\hline PEL & Probable Effect Level \\
\hline ppb & parts per billion \\
\hline ppm & parts per million \\
\hline PQL & Practical Quantitation Limit \\
\hline $\mathrm{ug} / \mathrm{l}$ & micrograms per liter \\
\hline $\mathrm{T}_{1 / 2}$ & Half Life \\
\hline TEL & Threshold Effect Level \\
\hline USGA & United States Golf Association \\
\hline CTL & Cleanup Target Level \\
\hline
\end{tabular}


SAMPLE IDENTIFICATION NOMENCLATURE

BBML. Briar Bay Golf Course Mix/load Site

BBF2. Briar Bay Golf Course Fairway \#2

BBF4. Briar Bay Golf Course Fairway \#4

BBL. Briar Bay Golf Course Pond

GCML. Golf Club of Miami Mix/Load Site

GCG13. Golf Club of Miami Green \#13

GCT10. Golf Club of Miami Tee \#10

GCL. Golf Club of Miami Pond

GPML. Greynolds Park Golf Course Mix/Load Site

GPG4. Greynolds Park Golf Course Green \#4

GPT8. Greynolds Park Golf Course Tee \#8

KBML. Key Biscayne Golf Course Mix/Load Site

KBF14. Key Biscayne Golf Course Fairway \# 18

KBT18. Key Biscayne Golf Course Tee \#18

KBL. Key Biscayne Golf Course Pond

PMML. Palmetto Golf Course Mix/Load Site

PMF18. Palmetto Golf Course Fairway \#18

PMG7. Palmetto Golf Course Green \#7

PML. Palmetto Golf Course Pond 


\section{INTRODUCTION}

The United States Golf Association estimated that approximately 500 million rounds of golf are played in the United States annually and that golfing represents an $\$ 18$ billion/year industry. The popularity of golfing has increased steadily over the past decade and between 1985 and 1990 the number of golfers increased from 17.5 to 25 million, this number was projected to increase to over 30 million by the year 2000 (Hong and Smith, 1996). To meet the increasing demand for the game the National Golf Foundation estimates that between 1990 and 1994 an average of 255 new golf courses were constructed each year.

Florida is arguably the golf course capital of the United States, home to approximately 1,000 courses occupying a total of 10,600 acres. The National Golf Foundation indicated that approximately 45,000 rounds of golf per year are played in Florida making it second only to California in terms of rounds played (National Golf Foundation, 1991). Miami-Dade County has a fair share of the Florida golf market with 35 golf courses occupying approximately 4,835 acres or 1.6 percent of the net land acreage (Miami-Dade County Department of Planning Development and Regulation, 1996)

The increasing popularity of the game has attracted public scrutiny and criticism regarding the potential environmental consequences of golf course construction and management. There is concern that agrichemical usage at golf courses can cause environmental contamination. The concern is very strongly echoed in areas like Florida and particularly South Florida where the sole source of drinking water is a shallow, surficial aquifer located three to ten feet below land surface (bls) in most urban areas. 
Several recent studies have attempted to elucidate some of the actual and potential environmental impact of the golfing industry. This study, funded by the Department of Environmental Resources Management (DERM) and the Florida Department of Agriculture and Consumer Services (FDACS) is one of several conducted on the South Florida environment.

The objective of the study was to determine the degree and extent to which groundwater, surface water, soils and sediment quality at golf courses in Miami-Dade County are impacted by agrichemicals used in turf management. In addition, the study sought to determine if the level of impact is consistent with management intensity (defined as quantities of chemicals applied) for different golf course areas (greens, tees, fairways and mix/load). 


\section{PREVIOUS STUDIES}

The occurrence of pesticide residues and nutrients in groundwater has been extensively studied. Over three hundred studies of pesticide occurrence in waters and soils have been carried out over the past thirty years. Most studies have either focused on agrichemicals used in traditional agriculture or have not attempted to associate pesticide occurrence with specific non-point sources. Very few studies have been done in non-agricultural areas associated with high agrichemical usage like golf courses and urban areas, despite application rates that often exceed those for most crops (USGS fact sheet, 1995).

The 1990 study by Cohen and colleagues is perhaps one of the most comprehensive thesis on the subject of pesticides in ground water at golf courses (Cohen et al., 1990). The studied focused on four golf courses on Cape Cod, Massachusetts, and involved investigation of seventeen pesticides and related chemicals. The most frequently detected chemical was dichlorobenzoic acid, the source of which was unknown. A total of eight pesticide residues were detected in groundwater with the most frequent detections associated with greens and tees. Only chlorodane was detected at concentrations exceeding the health advisory level (HAL). Nitrate-nitrogen was detected but at concentrations below the guidance concentration of ten (10) parts per million (ppm). Only chlorodane and heptachlor epoxide was detected in soils from the study area.

In another study conducted off the coast of Maui (Hawaii) marine sediments associated with golf course runoff were examined for pesticides (Miles et al., 1992). Nineteen sediment samples were analyzed for metribuzin (herbicide) and chlorpyrifos (insecticide). Chlorpyrifos was detected in one sediment sample. Wan and his colleagues examined ten samples obtained from golf course waters (ponds or standing water) for thirty-three pesticides (Wan et al.,1996). Two pesticide residues were detected. 
In examining the potential movement of the herbicide dithiopyr from simulated golf course greens, Hong and Smith found that only 0.6 percent of the applied herbicide was found in the leachate collected in the field lysimeters. Less than 2 percent was transported from the treated plots in runoff water (Hong and Smith, 1996). By contrast up to 11.5 percent of the applied insecticide chlorpyrifos was recovered in leachate from soil columns in a study to examine the movement of pesticides under different irrigation regimes (Starrett et al., 1994).

A two year study investigation by the United States Geological Survey (USGS) examined nine golf courses in Florida. The study looked at forty-one pesticide residues in groundwater, surface water, irrigation water and effluent water (Swancar, 1996). Pesticide residues were detected in groundwater at seven of the nine golf courses studied. Three pesticide residues, arsenic, acephate and bentazon occurred at concentrations above their maximum contamination level (MCL) or guidance concentration. Pesticides were also detected in pond water.

The United States Golf Association (USGA) has sponsored research to determine the impact to ground and surface water of several pesticides and fertilizer used at golf courses. These studies indicate that the fate of pesticides and fertilizers applied at golf courses is influenced by a myriad of factors including but not limited to turfgrass variety, soil type, irrigation regime, interval between treatment and significant rainfall event, and pesticide property (USGA, 1995).

Personal communication with personnel from the Florida Department of Environmental Protection (FDEP) indicate that arsenic has been found in groundwater and soils at golf courses, in South Florida, at concentrations in excess of the maximum contamination level (MCL) and soil cleanup target level (CTL) respectively. In addition, data collected at golf courses in MiamiDade County during routine permitting activities by personnel from DERM indicate soil and groundwater contamination by arsenic and nitrates (DERM records). 


\section{METHODOLOGY}

\section{DESCRIPTION OF STUDY AREA}

\section{General Description}

Miami-Dade County, established in 1838 , is located near the southeastern tip of the Florida peninsula. The estimated 2000 square miles that comprises Miami-Dade County is bordered on the north by Broward County, on the south by the Florida Keys (Monroe County), by the Biscayne National Park and the Atlantic Ocean on the east and Collier and Monroe County on the west (Figure 1).

Figure 1: Map of Florida

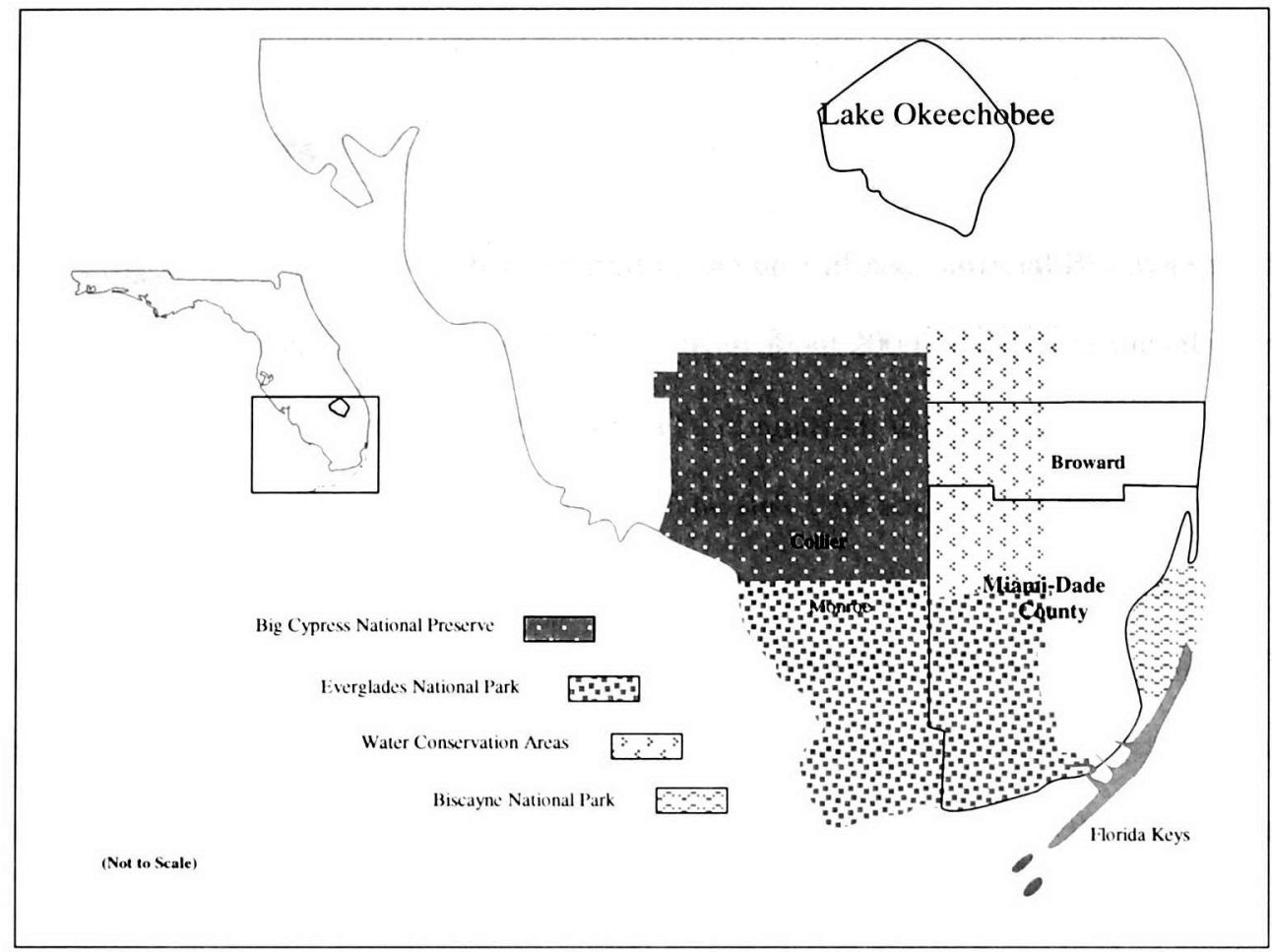


Development in Miami-Dade County is restricted to the eastern portion of the county since the western portion, is designated as part of the Everglades National Park (ENP). Prior to development, the area consisted of vast wetlands extending eastwards to within five miles of the coastline and a coastal fringe consisting of sandy flatlands, coastal marshes and mangrove swamps (Fish and Stewart, 1991). To allow for development, a network of canals was dug during the 1920's to drain swampy areas and provide flood protection for the resulting urban and agricultural areas.

The area is characterized by a subtropical climate with characteristic wet, warm, humid summers and dry, mild winters. Average daytime temperatures range from 82 degrees during summer to 68 degrees in winter with an average annual precipitation of approximately 57.6 inches. Average relative humidity is about 74 percent (Noble et al., 1996).

\section{Hydrologic Setting}

The hydrogeology of the area is characterized by the unconfined, surficial Biscayne aquifer. The aquifer is wedge-shaped and varies in thickness from about 200 feet below sea level near the coast narrowing progressively to become a thin layer approximately 20 feet thick on the western border of the county (Radell and Katz, 1991). The Biscayne aquifer was designated a sole source aquifer by the United States Environmental Protection Agency (USEPA) in 1979 since it is the only source of potable water for most of southeast Florida. The aquifer consists of highly permeable interbedded limestone and sandstone formed during the Miocene through Pleistocene eras and has the distinction of being one of the most permeable aquifers in the world (Parker et al., 1955). Below the Biscayne aquifer is a layer of dense and impermeable deposits, the Floridan aquiclude. A deeper aquifer system, the Floridan aquifer, occurs beneath the impermeable aquiclude, at about 1000 feet below sea level (Fish and Stewart, 1991). Regional groundwater 
flow for Miami-Dade County (Figure 2) is southwesterly towards Everglades National Park and Florida Bay in the undeveloped western portions of the county. In the developed eastern portion of the county ground water flow is in a general east-southeasterly direction, unless subjected to anthropogenic influences, with ultimate discharge into Biscayne Bay (Fish and Stewart 1991).

Figure 2: General ground water flow direction for Miami-Dade County (Fish and Stewart, 1991)

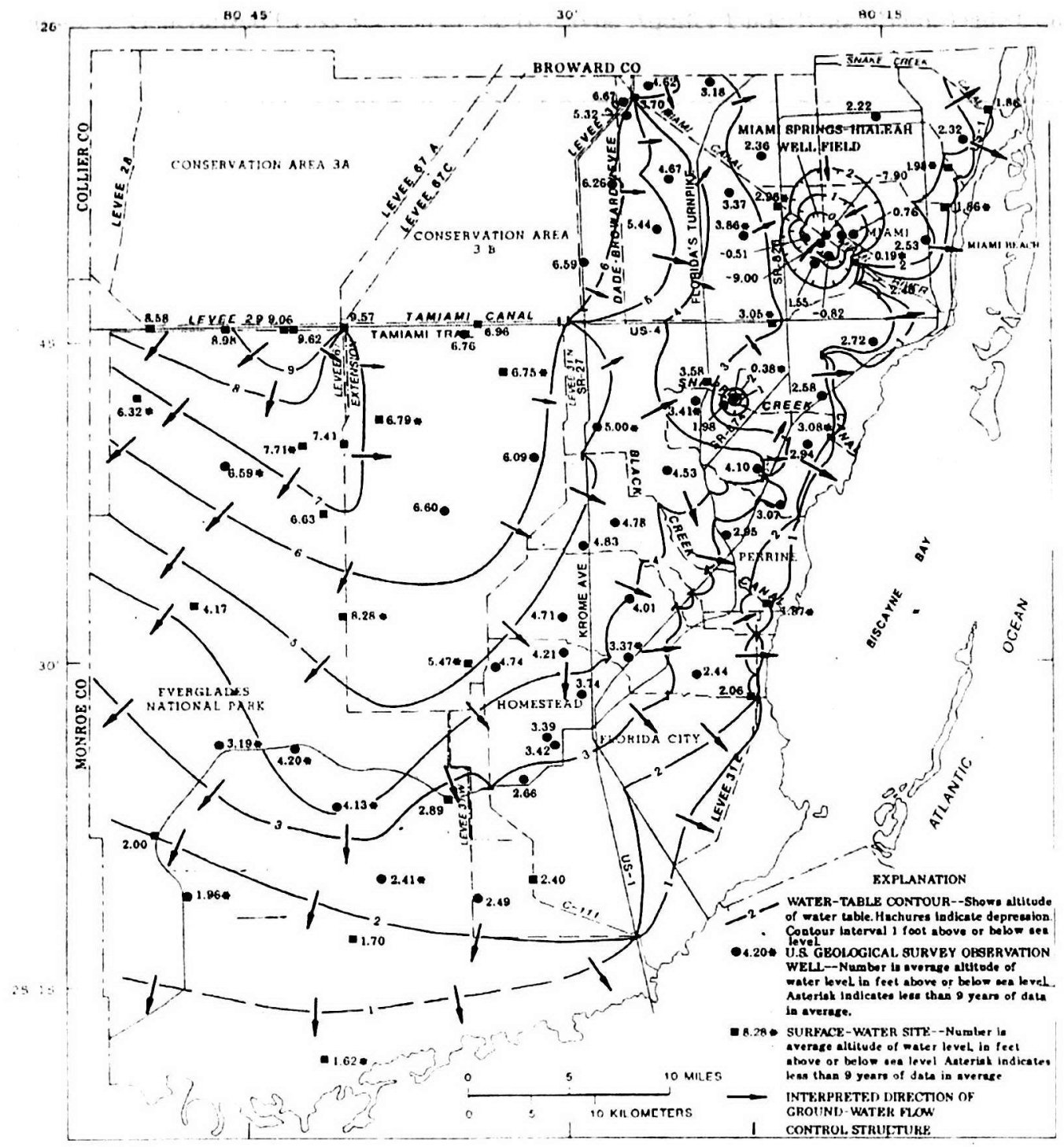


Figure 3 indicates a general cross section of Miami-Dade County showing the Biscayne Aquifer The two main sources of recharge for the Biscayne aquifer are precipitation and infiltration of surface water from canals and the conservation areas (Fish and Stewart, 1991). Recharge from precipitation is the dominant mechanism during the wet season (Radell and Katz, 1991) averaging 37 to 38 inch annually. During the dry season infiltration from canals and conservation areas is the dominant recharge mechanism.

Figure 3: Generalized Cross Section of the Biscayne Aquifer Underlying Miami-Dade County

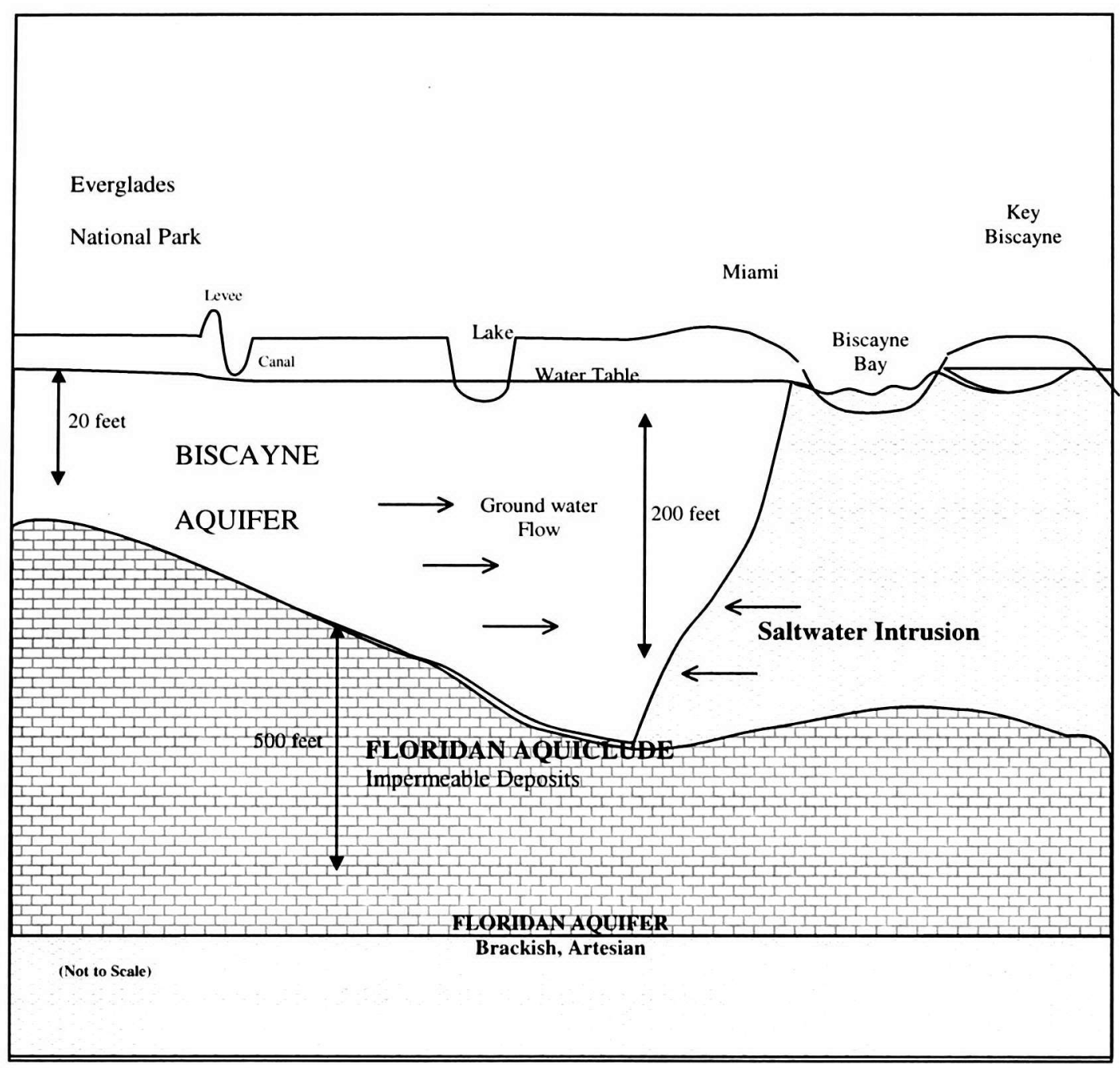




\section{MONITORING PROGRAM DESIGN}

The monitoring program was designed to establish soil and groundwater monitoring sites at agrichemical mix/load areas (designated areas where fertilizers and pesticides are prepared and loaded into application equipment) and adjacent to play areas (tees, greens and fairways). In addition, golf course ponds were used for water and sediment sampling.

\section{Groundwater}

In February 1997, six monitoring wells were installed at each of the selected golf courses. The wells were installed as three clusters consisting of two wells each. Each well cluster consisted of a shallow well (7-12 feet deep) with five feet of screening set such that two feet of screening extended above the water table and a deeper well (23-28 feet) with two feet of screening 20 feet below the water table. All wells were constructed using 2 inch diameter 40 schedule PVC. Wells were installed using the hollow stem auger method with the deeper wells being installed first to prevent the possibility of moving contaminants from shallow to deeper zones. Auger bits and drilling equipment were steamed cleaned between wells to prevent cross contamination. During the drilling operation all equipments were placed on plastic sheeting to prevent contact with potentially contaminated turf grass. Monitoring wells were developed using the over pumping method.

The study design dictated that, at each of the golf courses, one well cluster was placed within or adjacent to the mix/load area. However, at the Golf Club of Miami and the Key Biscayne Golf Course, the presence of underground or overhead utility conduits precluded the installation of wells in the immediate vicinity of the mix/load area. The mix/load wells at these two courses were installed at a distance of 200 and $82 \mathrm{ft}$ away respectively. 
The other two clusters were placed adjacent to two of the three main types of play areas, greens, tees and fairways (Figures 4-8). Monitoring wells were sited to avoid low areas that receive runoff during normal rainfall events. The actual distribution of monitoring well sites at each golf course is indicated in Table 1.

In addition, three pre-existing monitoring wells located in residential areas in proximity to three golf courses were selected for sampling to provide information on current background concentrations of the analytes of interest to the study. The background wells were selected from an Ambient Water Quality Monitoring (AWQM) countywide network of monitoring wells. The AWQM network is comprised of wells installed by the United States Geological Survey (USGS), the Florida Department of Environmental Protection (FDEP), or DERM. DERM staff routinely monitors these wells to provide ambient water quality information. The only criterion for background well selection was that the selected well was the closest available AWQM well to a participating golf course.

The data from the three selected background wells were combined with historical data from the AWQM network to provide background information for analysis and discussion.

Table 1: Distribution of Monitoring Well Sites by Type of Golf Course Area

\begin{tabular}{|l|l|l|l|l|l|}
\hline & Briar Bay & Golf Club & Greynolds & $\begin{array}{l}\text { Key } \\
\text { Biscayne }\end{array}$ & Palmetto \\
\hline Mix/load & $\mathrm{X}$ & $\mathrm{X}$ & $\mathrm{X}$ & $\mathrm{X}$ & $\mathrm{X}$ \\
\hline Fairway & $\mathrm{X} \mathrm{X}$ & & & $\mathrm{X}$ & $\mathrm{X}$ \\
\hline Green & & $\mathrm{X}$ & $\mathrm{X}$ & & $\mathrm{X}$ \\
\hline Tee & & $\mathrm{X}$ & $\mathrm{X}$ & $\mathrm{X}$ & \\
\hline
\end{tabular}


Although there might be differences in sampling methodology, well design and construction between the background wells and the golf course wells, the data should be comparable since the data from shallow and deep golf course wells were compared to wells of similar depth to ensure that the same layer of the aquifer was being evaluated.

The 30 golf course monitoring wells along with the three background wells were sampled four times during 1997 (February, May, August and November). In addition, the wells were sampled during March 1999, as a follow up to the study.

During each sampling event, a Hydrolab $\circledast$ H2O Multiprobe with Hydrolab $\circledast$ Surveyor 3 Display Logger was used to measure field parameters; temperature, $\mathrm{pH}$, specific conductivity, redox potential, dissolved oxygen and salinity.

All field activities were performed in accordance with an approved project-specific quality assurance plan. A total of five well volumes of water were purged from each well prior to sampling. Wells were purged using a gasoline powered centrifugal pump with a one-inch diameter PVC hose assembly on the intake and outlet sides. The intake end of the PVC pipe was fitted with a 2 feet Teflon ${ }^{T M}$ tube equipped with a foot valve to prevent backflow into the well. In the event that it was not possible to purge with a centrifugal pump a Teflon bailer was used.

Groundwater samples were obtained using a peristaltic pump and Teflon ${ }^{\mathrm{TM}}$ tubing. Samples were collected in sequence: pesticides, nutrients then metals. For pesticide sampling a Teflon ${ }^{\mathrm{TM}}$ trap was fitted between the intake and pump head and the samples were obtained from the trap. Precleaned equipment was used for each well. The samples were placed in appropriate sampling containers, placed on ice and transported to the laboratory. 


\section{Soil}

Both soil core samples and surficial soil samples were collected during the study. During monitoring well installation (February 1997), a stainless steel split spoon was used to obtain soil samples at two-foot intervals down to the soil/groundwater interface. A total of 43 soil core samples were collected from the deeper monitoring well sites and analyzed to evaluate vertical distribution of the parameters of interest in the vadose zone.

During the May, August and November sampling events, surficial $(0-1 \mathrm{ft})$ soil samples were obtained from targeted play areas. The soil samples were collected as 15 sub-samples obtained approximately ten feet apart around the perimeter of the targeted area (green, tee, fairway or mix/load area). Samples were collected using a stainless steel, one-inch diameter soil probe. The sub-samples were composited using a stainless steel mixing tray and spoon.

\section{Surface Water and Sediments}

With the exception of Greynolds Golf Course, all the courses participating in the study had ponds. At each golf course one pond was selected for sampling. The main criterion for pond selection was location relative to a groundwater- monitored area. The selected pond was located such that it would receive surficial storm-water runoff from an area being monitored for groundwater quality. The ponds were located within 100 to 160 feet from a monitoring well and were sampled during May, August and November 1997. Surface water samples were collected from the center of the selected pond at a depth of approximately 3 feet below water surface using a Niskin $^{\mathrm{TM}}$ sampler. The sampling point was accessed by boat. Sediment samples were collected as a grab sample using a stainless steel Ponar ${ }^{\mathrm{TM}}$ Grab Sampler. Samples were obtained in the general vicinity of the surface water sampling area. 


\section{Study Site Selection}

Five golf courses, owned by the Miami-Dade Park and Recreation Department; Palmetto Golf Course, Briar Bay Golf Course, Key Biscayne Golf Course, Greynolds Park Golf Course, and Golf Club of Miami were selected participate in the study.

Ideally, to facilitate statistically sound extrapolations and generalizations, golf courses should have been randomly selected from among the active golf courses in Miami-Dade County. However, the limitations of the study precluded the use of randomly selected courses. Instead, golf course selection was based exclusively on logistic and accessibility considerations.

Notwithstanding the lack of randomness in course selection, the five golf courses are representative of golf courses in Miami-Dade County in terms of size, age, and design. Average acreage for the participating golf courses was 130 acres for eighteen hole courses and 45 acres for nine hole courses, this compares to a countywide average of 133 and 48 acres for eighteen and nine hole courses, respectively Average age for golf courses countywide is 36 years similar to the 35 years average for the golf courses studied (DERM Agricultural Waste Permitting files, 1996-1998 inspection reports).

Although environmental setting with respect to soil type, geology and physiological features were not factors that influenced golf course selection, the selected courses exhibited diversity with respect to these parameters. Soils encountered in the study ranged from urban fill to fine sands overlying bedrock that varies from porous oolitic limestone to hard, fossilized formations. Groundwater was encountered at three to eight feet below land surface and exhibited salinity ranges from saline to freshwater. 
The study design recognized that the selected courses were probably not representative of golf courses in Miami-Dade County in terms of pesticide usage. Due to differences in management practices, public golf courses typically use less pesticide and fertilizer than privately owned courses. Information from a pesticide use survey, at eight golf courses in Miami-Dade County (DERM Agricultural Waste Permitting files, 1996-1998 inspection reports) indicated an average of 104 gallons and 1630 pounds of pesticides (product weight) used annually at public golf courses surveyed compared with 204 gallons and 3656 pounds at private golf courses. Pesticide inventories obtained from public and private golf courses between 1994 and 1996 (DERM Agricultural Waste Permitting files, 1996-1998 inspection reports), indicated that, notwithstanding the differences in quantities of products used, the active ingredients used do not differ significantly between public versus private golf courses countywide. In addition, application rates are assumed to be the same per active ingredient.

\section{Specific Site Descriptions}

\section{Palmetto Golf Course}

The Palmetto Golf Course was established in the early 1960's and occupies approximately 120 acres in southwest Miami-Dade County. South Dixie Highway and Coral Reef Drive border the golf course on the east and north sides respectively while residential development occur on the west and south sides (Figure 4). Aerial photographs from the 1950's indicate that the area was farmed prior to being developed as a golf course.

The Soil Survey of Miami-Dade County (Noble et al., 1996) describes soils in this area as Udorthents consisting mainly of fill material over hard limestone substratum. These soils are usually associated with urban built-up areas and are considered well suited for golf courses. Lithology logs obtained during the installation of monitoring well for the study indicate that the 
area consists of a layer of silt to clayey sands down to approximately 5 feet. Miami Oolite limestone subtends the sands and extends to approximately 24 feet. A layer of soft, pale yelloworange lime mud occurs between 24 and 30 feet, the maximum depth drilled.

The golf course is located on the edge of the Atlantic Coastal Ridge and, as such, the land surface elevations here are the highest encountered during the study. This is especially true along the eastern perimeter of the course. Elevations ranged from 12 to 13 feet above sea level on the east side of the golf course to approximately 8 feet on the north and southwest sides (Dade County Public Works Department, 1955).

The C-100 canal, which forms a part of the county-wide drainage canal network, traverses the property in an approximate northwest to southeast direction. Measurements obtained during the study indicate that groundwater occurs between 2.7 and 5.5 feet above sea level with the deeper groundwater occurring to the east. Groundwater is assumed to follow regional flow direction except in the vicinity of the C-100 canal where it seems logical to expect that groundwater is influenced by the canal.

The golf course is irrigated by groundwater extracted from the underlying Biscayne aquifer. Two wells located on the northwest side of the golf course supply water for irrigation. The wells are located within 500 feet of the C-100 canal.

\section{Briar Bay Golf Course}

Briar Bay Golf Course (Figure 5), established in 1974 is a nine-hole facility that occupies approximately 30 acres. It is located approximately one half mile west of the US I(South Dixie Highway) in southwest Miami- Dade County. The C-100C canal runs parallel to the golf course on the west and south sides at a distance of approximately a quarter of a mile. 
Prior to 1971 the area supported very dense pineland vegetation. The forest was cleared between 1971 and 1972 to allow for diversion of the C-100C canal that had historically ran along the current eastern boundary of the golf course. Between February and December of 1972 and the $\mathrm{C} 100 \mathrm{C}$ canal was diverted from its historical location along the current eastern boundary of the golf course to its current location approximately 300 feet west of the golf course. Construction on the golf course began in 1973 .

Soils in this area are Biscayne marl drained, and consist of 5-12 percent clay and 1-2 percent organic matter (Noble et al., 1996). These soils are very shallow and poorly drained with moderate permeability. With regular applications of fertilizer these soils are considered suitable for the growth of Bermuda grass, the preferred grass for golf course playing surfaces in the southeast United States.

Lithology information obtained during monitoring well installation for this study revealed that the upper four feet consisted of limestone fragments which appeared to be fill material overlying Miami Oolite, which occurs down to twenty three feet. At approximately twenty-three feet a harder formation of Key Largo limestone was encountered. Land surface elevation is between 8 and 10 feet above sea level (Dade County Public Works Department, 1955).

The golf course is irrigated using groundwater supplied by a single irrigation well that produces from the Biscayne aquifer. Depth to groundwater encountered during the study ranged from 2.7 to 4.2 feet above sea level. Groundwater measurements obtained during the study indicated that localized groundwater flow is in a northerly direction. 


\section{Key Biscayne Golf Course}

The Key Biscayne Golf Course (recently renamed Crandon Golf Course) was established in 1972. This 18-hole course occupies approximately 125 acres on the island of Key Biscayne located off the southeast coast of Miami-Dade County. Biscayne Bay borders it on the west, Crandon Boulevard on the east, an area of undeveloped land to the north and the Lipton Tennis Center to the south (Figure 6).

Prior to the establishment of the golf course, the southern one-third of the property was used as a municipal dump for the island of Key Biscayne. The remainder of the property was undeveloped wetlands. The dump was closed during the 1970's (DERM Waste Regulation Section, Crandon Dump files).

Soils in this area are of the St Augustine Series (Noble et al., 1996). St Augustine sands are somewhat poorly drained with less than 2 percent slope and 2-20 percent permeability. Soils of this type typically contain of 1-3 percent organic matter.

Information obtained from lithology logs during well drilling for this project revealed a very distinct, fibrous, dusky brown, peat layer approximately 1 foot deep. This layer occurred at depth of approximately 6 feet below land surface (bls). This layer had a very swampy odor and is probably derived from mangrove debris. A layer of limestone fragments and sand overlie the peat. Subtending the peat to a depth of about 22 feet is a layer of dark brown soupy sand. A limestone formation is beneath the sand layer.

The groundwater beneath the golf course is subject to tidal influences especially to the west where the play areas are sometimes located within 30 feet of the Biscayne Bay. The chemistry of the groundwater reflects a tidal influence with specific conductivity reading as high as 15900 uhs $/ \mathrm{cm}$, along the western fringe. A conductivity gradient observed between shallow and deeper 
wells, especially along the west side of the course, suggests that a lens of brackish to fresh water overlays the more tidally influenced saline waters.

The land surface lies at approximately 5 feet above sea level and groundwater occurs between 1 and 3 feet above sea level. The prevailing direction of groundwater flow is north towards Biscayne Bay. The golf course uses utility water for irrigation since the salinity of the groundwater precludes its use.

\section{Greynolds Park Golf Course}

This golf course was established in the 1950's as a part of the Greynolds Park recreation and preservation area in northeast Miami-Dade County. The nine-hole golf course occupies 50 acres on the southwest side of the park and is surrounded by residential development on the north, west and south sides (Figure 7). The park itself lies just north of the Oleta River State Recreation area and consists of wetlands and oak mixed with slash pine vegetation. The Oleta River forms the eastern boundary of the Park.

Soils in this area are Miami-Dade fine sand and are described as moderately deep and well drained with very high permeability $(<20 \mathrm{inch} / \mathrm{hr})$. These soils typically consist of $0-5$ percent clay and 0-5 percent organic matter. They are considered suited for the growth of Bermuda grass when properly managed.

Since the site sits on the Atlantic Coastal Ridge, it is one of the highest points in Miami-Dade County. Elevations on site range from 9 to 10 feet above sea level (Dade County Public Works Department, 1955).

Lithology information obtained from the site indicates two feet of organic material overlying very pale orange limestone down to at least thirty feet on the north side of the course. In the more 
southern areas of the course, four to six feet of light gray to orange sand overlay the limestone bedrock. The limestone formation is believed to be Miami Oolite.

The golf course is irrigated with groundwater accessed using three irrigation wells on site. Water level measurements obtained during the study reveal groundwater occurs between one and two feet above sea level, with an easterly flow towards the Oleta River.

\section{Golf Club of Miami}

Established in 1962, this 160 acres course located in northwest Miami-Dade County is bordered on the south by Miami Gardens Drive and on all other sides by residential developments. The course actually meanders around several residential developments. The course is located within 350 feet of the Peter Pike Canal on the north and west sides (Figure 8)

Soils in this area are broadly described as Udorthents, consisting of fill material over hard limestone substrata. These soils, which are moderate to well drained and are typically located in built up areas and are considered well suited for golf courses (Noble et al., 1996). Lithology information obtained during monitoring well installation indicates that the area consists of a soft, very pale orange, sub rounded sand to $20-23$ feet. The sand layer overlies a hard, fossilized limestone substratum thought to be the Fort Thompson Formation. Land surface elevations range from 4-6 feet above sea level (Dade County Public Works Department, 1955).

The golf course is irrigated using groundwater as well as water from the ponds on the golf course. There are four irrigation wells. The ponds at the golf course receive storm-water runoff from the adjacent residential developments via a series of storm sewers pipes. The pond discharge to the adjacent Peter Pike Canal as necessary when the golf course becomes inundated. 
Figure 4: Site diagram of Palmetto Golf Course

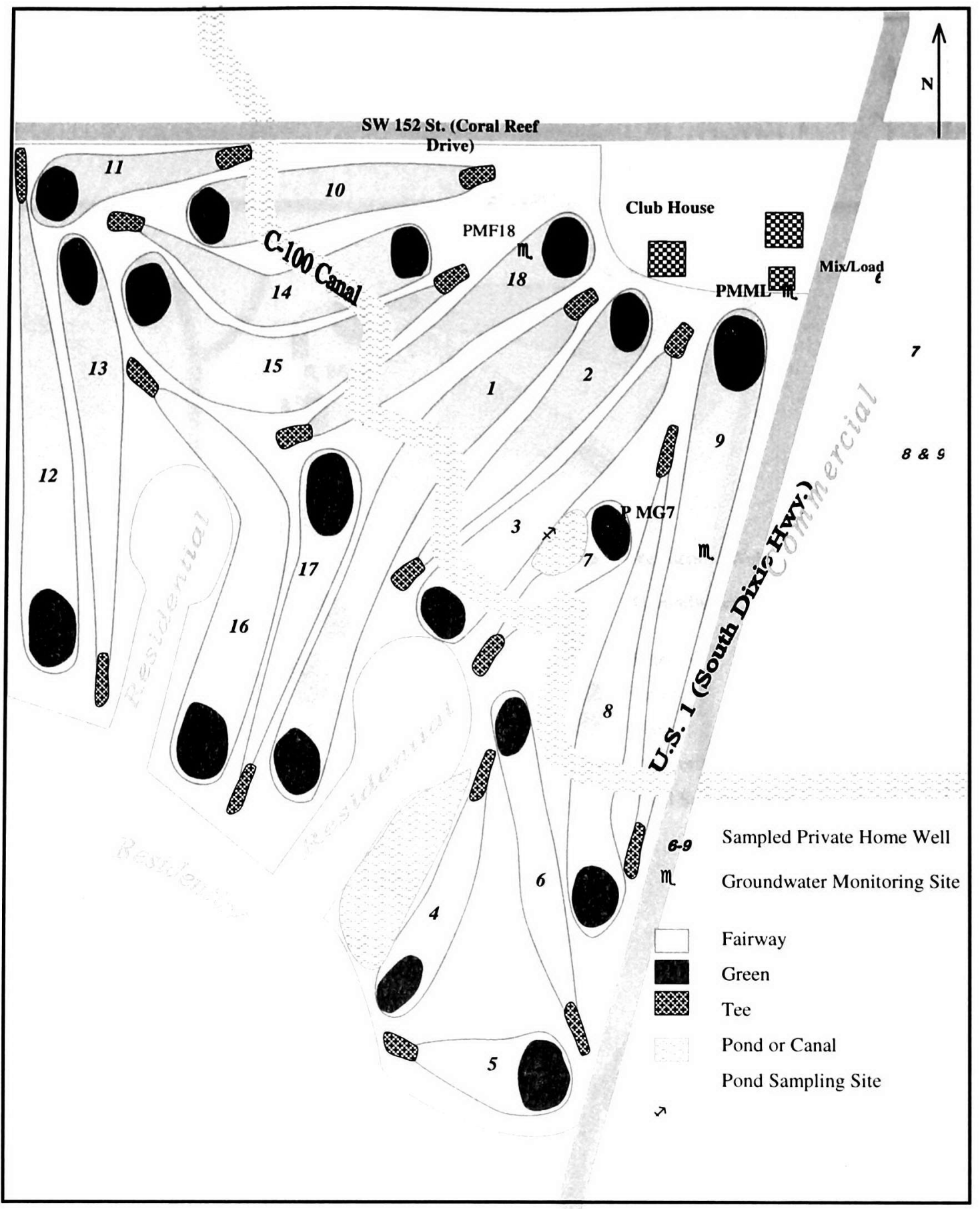


Figure 5: Site diagram of Briar Bay Golf Course

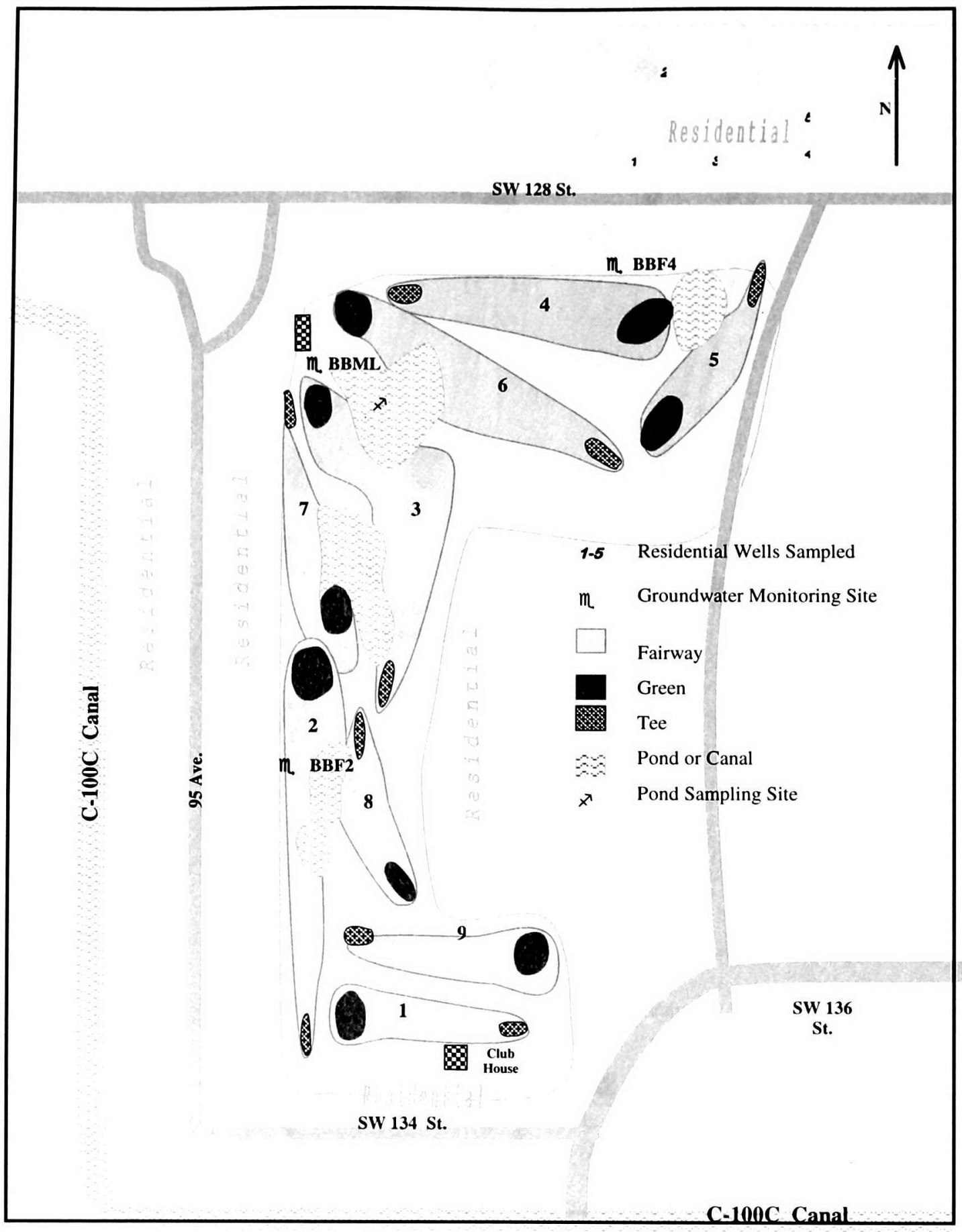


Figure 6: Site diagram of Key Biscayne Golf Course

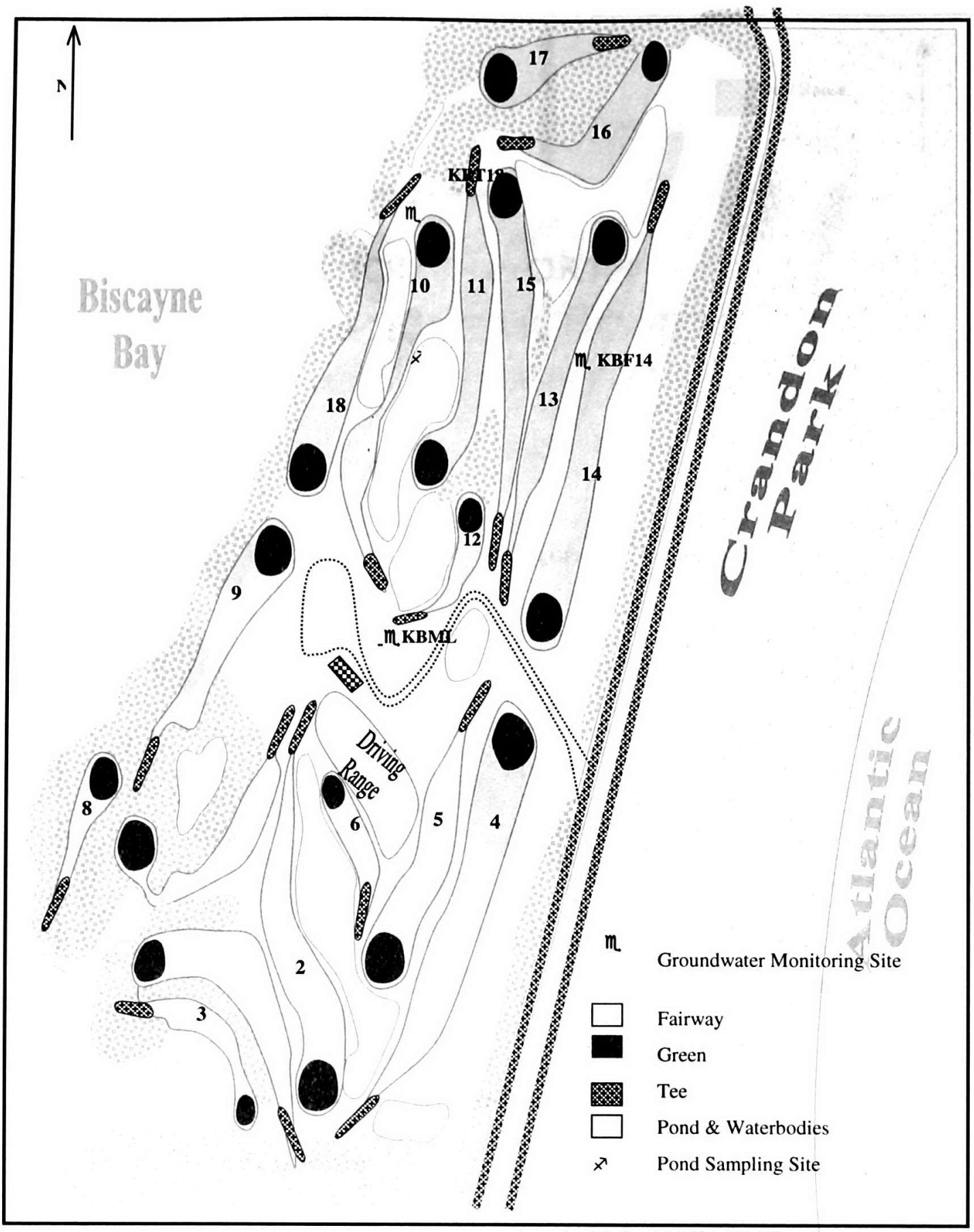


Figure 7: Site diagram of Greynolds Golf Course

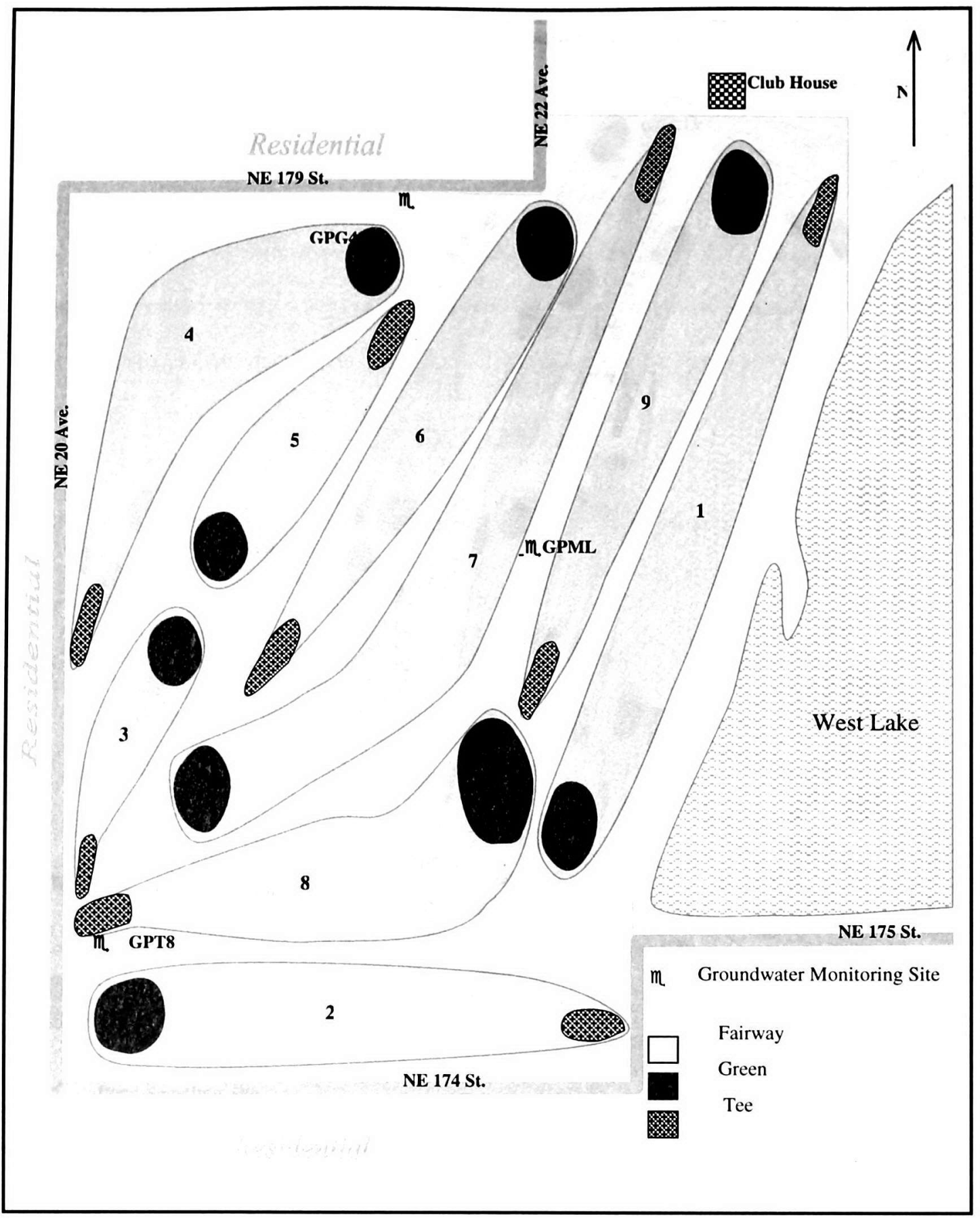


Figure 8: Site diagram of Golf Club of Miami

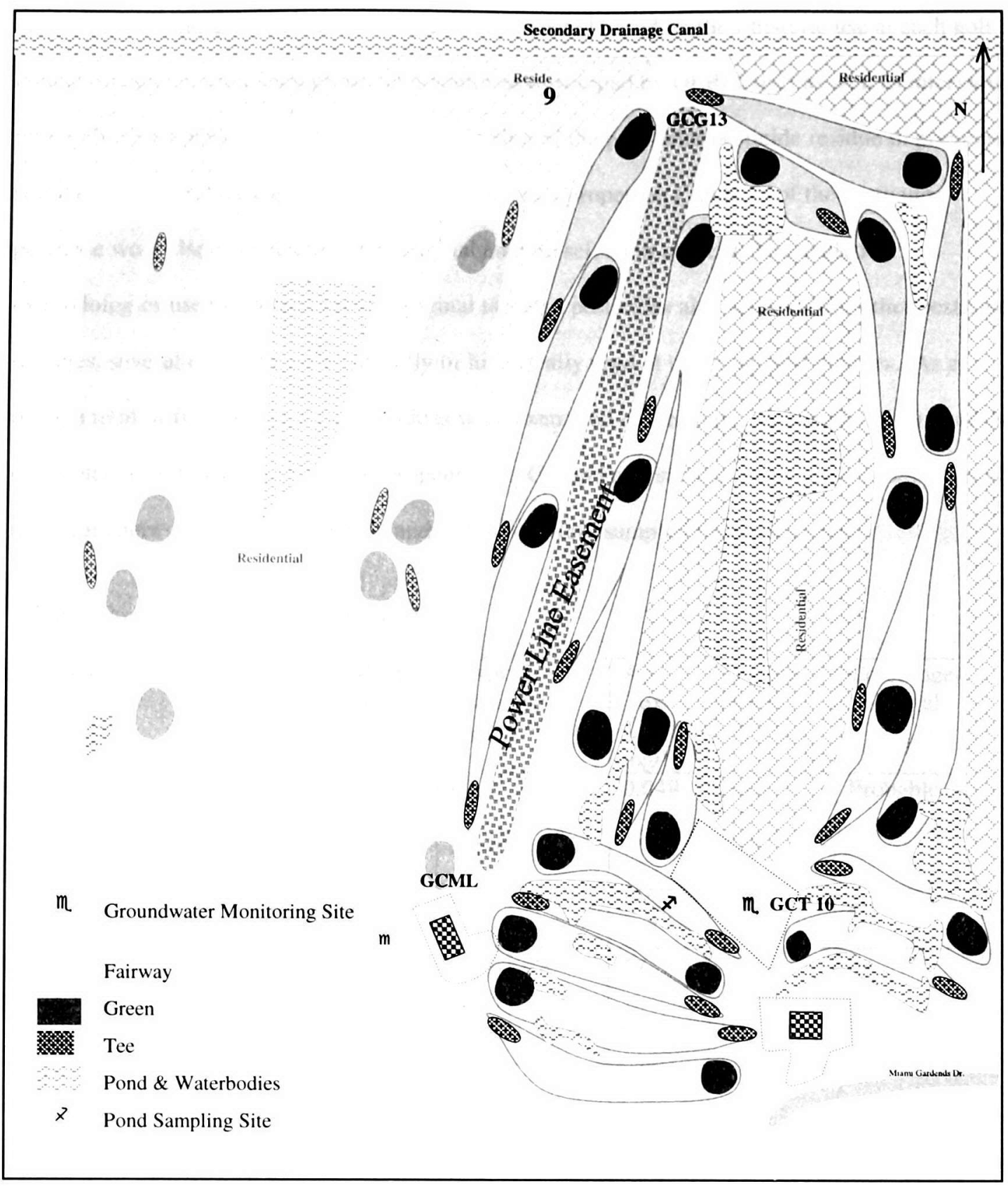




\section{PARAMETERS OF INTEREST}

Initially, five pesticides were targeted for groundwater study: prodiamine, fenamifos, metribuzin, chlorothalonil and arsenic. The pesticides were selected based on their historic use at each golf course (documentation from pesticide inventories developed by DERM staff as well as interviews with golf course personnel), documented detection of the particular pesticide residue in previous studies, and laboratory capability. Physical/chemical properties (Table 2) of the particular pesticide were also considered in the original analyte selection process. The analytical methodologies used to screen for the original targeted pesticides also screened for other pesticide residues, several of which were currently or historically used at the study golf courses. As a result a total of fifty-one pesticide residues were examined in the study. A complete listing of the parameters of interest is provided in Appendix 1. Ground and surface water were sampled for all the parameters of interest while soils and sediments were sampled for metals only.

Table 2: Properties of Targeted Pesticides

\begin{tabular}{|l|l|l|l|l|l|l|}
\hline Pesticide & $\begin{array}{l}\text { Solubility } \\
\text { ppm } *\end{array}$ & $\begin{array}{l}\text { Halflife } \\
\text { Soils* } \\
\mathrm{T}_{1 / 2}\end{array}$ & $\begin{array}{l}\text { Pesticide } \\
\text { Movement } \\
\text { Rating } \lambda_{*}\end{array}$ & $\begin{array}{l}\text { Aq } \\
\text { Tox } \\
\text { LC50* } \\
\text { mg/l }\end{array}$ & $\begin{array}{l}\text { Ground } \\
\text { Water } \\
\text { CTL }\end{array}$ & $\begin{array}{l}\text { Carcinogen } \\
\text { Potential }\end{array}$ \\
\hline Chlorothalonil & 0.6 & 30 & Low & 0.049 & 3.18 & Probable \\
\hline Metribuzin & 1200 & 40 & High & 76 & 175 & D \\
\hline Fenamifos & 400 & 50 & High & 0.11 & 2 & D \\
\hline MSMA & $10^{6}$ & 180 & Very Low & na & $50^{* *}$ & na \\
\hline Prodiamine & 0.013 & 120 & Very Low & na & na & na \\
\hline
\end{tabular}

* Wauchope et al., 1992, ${ }^{\lambda}$ Derived from Groundwater Ubiquity Score (GUS)

• : Chapter 62-777, Florida Administrative Code,

D: Inadequate evidence of human or animal carcinogenicity, ${ }^{* *}$ : based on arsenic 


\section{LABORATORY METHODS}

The Florida Department of Environmental Protection (FDEP) laboratory in Tallahassee, Florida performed all pesticide analysis. Chlorinated pesticides in water were analyzed using a modified EPA Method 608 while organonitrogen-phosphrous pesticides in water were analyzed using a modified EPA Method 614. The FDEP laboratory was also responsible for groundwater and surface water arsenic analysis. Arsenic in water was analyzed using the Induced Coupled Plasma (ICP) Atomic Emission Spectrometric Method described as EPA Method 200.7. Laboratory quality control was in accordance with the quality control objectives outlined in the DEP Comprehensive Quality Assurance Plan (CompQAP) \# 879688G

The DERM laboratory analyzed soil and sediment samples for arsenic using EPA Method 7060. The groundwater nutrient samples obtained during the February sampling were analyzed by the DERM laboratory using EPA Method 353.2 for nitrates and EPA Method 365.1 for total phosphates. Laboratory quality control was in accordance with the quality control objectives outlined in CompQAP \#871238.

The Post Buckley Schuls and Jernigan (PBS\&J) Environmental Laboratory in Orlando, Florida, analyzed ground and surface water nutrient samples from the May, August and November sampling. EPA Methods 353.2 and 365.1 were used for analysis of nitrates and phosphates in water respectively. The analytical methodology followed was EPA Method 365.1. Laboratory quality control was in accordance with the quality control objectives outlined in CompQAP \#860044G

Arsenic mobility and toxicity are profoundly influenced by the arsenic species present. To obtain information on the actual species of arsenic present in soils and groundwater at the golf courses, selected samples were submitted for arsenic speciation analysis. Five groundwater and six soil 
samples from the August sampling event were speciated to determine the arsenite (As $3+$ ), arsenate (As 5+), and monomethylarsinic acid (MMAA) component of the samples. EPL Bio Analytical Laboratories located in Harris town, Illinois, performed the speciation analysis. Soil samples were extracted using ammonium hydroxide prior to analysis by GC/MS. Arsenic species in water samples were determined by GC/MS analysis of the thioglycolate derivatives.

\section{STATISTICAL METHODS}

Statistical analyses were performed using SPSS ${ }^{\mathrm{TM}}$ (Students Version 8.0 Software for Windows) and Sigma Stat ${ }^{\mathrm{TM}}$ (Version 2.0 for Window). Preliminary data analysis using the KolmogorovSmirnov test indicated that most of the groundwater and soil profile data sets were not normally distributed. The distribution could not be normalized using the popular transformation techniques. Based on the indication of non-normality in the data distribution, subsequent analyses were performed using non-parametric statistics.

Non-parametric statistical methods are independent of the shape of the sample distribution, use ranked data instead of raw data and are typically more conservative than parametric tests. For non-parametric testing the values in the data sets are ranked from lowest to highest with the lowest measurement assigned a value of one and the second lowest a value of two etc. (Zar, 1996). The assigned ranks are subsequently used in analysis.

The Spearmans Ranked Correlation was used to evaluate linear relationships between variables of interest. The Mann Whitney, Kruskal-Wallis, Dunn Pairwise Multiple Comparison Procedure, and the Tukey-Type Multiple Comparison tests were used to analyze the soil and groundwater data for statistically significant differences in analyte concentration between golf courses and among golf course play areas. The Mann-Whitney test is the non-parametric analog to the two- 
sample $t$ test and is used to test for differences between two populations. The Kruskal-Wallis test is the non-parametric alternate to the one-way ANOVA and is used to test for differences among three or more populations. The Kruskal-Wallis statistic can indicate when differences exist between comparison populations but is incapable of locating which populations differ. The Dunn -Pairwise or the Tukey-Type Multiple Comparison Procedure was used to isolate the group or groups that differ when a difference has been indicated by the Kruskal-Wallis analysis.

For comparisons between golf courses, the data points from each golf course were grouped together and each golf course treated as a sample population. To examine differences among golf course areas, data from each of the four areas (greens, tees, fairways, and mix/load) were combined to give four sample populations. 


\section{RESULTS}

\section{Field Measurements}

The box plots presented as Figure 9 summarizes the range of values obtained from the study site with regards to the physical parameters ( $\mathrm{pH}, \mathrm{DO}$, redox, salinity and specific conductivity) and compares these to concentrations from ambient groundwater for Miami-Dade County.

Except for the deep monitoring wells at Palmetto Golf Course, $\mathrm{pH}$ encountered at the study sites was within the range of expected background $\mathrm{pH}$ for Miami-Dade County. The $\mathrm{pH}$ encountered in the deep wells at Palmetto Golf Course was higher than at the other sites. The elevated $\mathrm{pH}$ in deep monitoring wells at Palmetto Golf Course may be attributable to the geology of the bedrock at the screened interval of the deep wells. Lithology information obtained during well installation indicated that a layer of soft lime mud occurs at approximately $24-30$ feet. The screened interval for these wells is $28-30$ feet.

Dissolved Oxygen (DO) in ambient groundwater is typically less than $1 \mathrm{mg} / \mathrm{l}$ with shallow groundwater being more oxygenated than deeper waters. Dissolved Oxygen readings encountered during the study was consistent with the background except for the shallow wells at Greynolds Park Golf Course. The DO reading for the shallow wells at Greynolds Park ranged from 0.3 to $3.1 \mathrm{mg} / \mathrm{l}$ with a median value of $1.98 \mathrm{mg} / \mathrm{l}$. The elevated DO readings at Greynolds Park Golf Course might results from the influence of the nearby Oleta River which runs parallel to the golf course along the eastern border.

Groundwater in the shallow Biscayne aquifer typically represents an oxidizing environment as indicated by the positive redox values obtained from the ambient program. Groundwater at the study sites represented both oxidizing and reducing environments. Redox values at Key Biscayne 
Golf Course were consistently negative indicating a reducing environment. Microbial activity associated with the peat layer encountered during well drilling could account for the anoxic environment at Key Biscayne.

Salinity values of less than one parts per thousand are usually indicative of fresh water. With the exception of groundwater below the Key Biscayne Golf Course, groundwater encountered during the study represented fresh water. Salinity values obtained from the deep wells at Key Biscayne Golf Course ranged from 0.7 to $6.1 \mathrm{ppt}$ with the highest values obtained from the tee wells. The high salinity at this site reflects the influence of saltwater intrusion. The salinity range for the shallow wells at Key Biscayne were significantly lower than for the deep wells and only slightly above background suggesting the presence of a layer of almost fresh water overlying the deeper brackish water.

Specific conductance was generally higher at golf courses that in ambient groundwater. Median specific conductance value from Key Biscayne Golf Course was over twice the median value found in ambient groundwater and almost twice the value encountered at any other golf course Specific conductance values greater than $1000 \mathrm{uS} / \mathrm{cm}$ is indicative of brackish water. The high specific conductance $(>10,000 \mathrm{uS} / \mathrm{cm}$ ) values from the deep tee wells at Key Biscayne describe moderately saline waters. 
Figure 9a-9e: pH, DO, Redox, Salinity and Specific Conductivity from five golf courses in Miami-Dade County

a) $\mathrm{pH}$

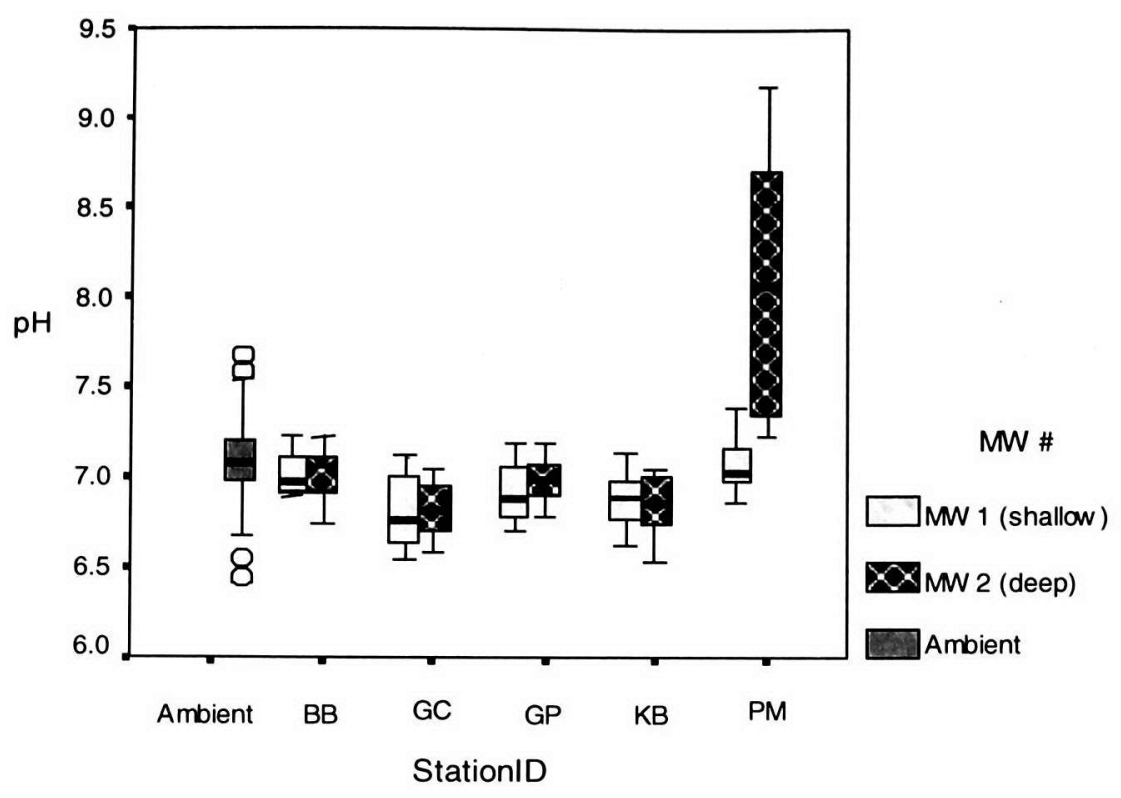

\begin{tabular}{|c|c|c|c|c|c|}
\hline \multirow{2}{*}{ Station ID } & \multirow{2}{*}{$\mathrm{N}$} & \multicolumn{4}{|c|}{$\mathrm{pH}$ values } \\
\cline { 3 - 6 } & & Min & Max & Mean & Median \\
\hline BB (MW1) & 12 & 6.89 & 7.23 & 7.02 & 6.97 \\
\hline BB (MW2) & 12 & 6.74 & 7.22 & 7.01 & 7.06 \\
\hline GC (MW1) & 10 & 6.54 & 7.12 & 6.79 & 6.77 \\
\hline GC (MW2) & 12 & 6.59 & 7.04 & 6.82 & 6.81 \\
\hline GP (MW1) & 12 & 6.69 & 7.18 & 6.92 & 6.88 \\
\hline GP (MW2) & 12 & 6.78 & 7.18 & 6.98 & 6.98 \\
\hline KB (MW1) & 12 & 6.62 & 7.13 & 6.89 & 6.89 \\
\hline KB (MW2) & 12 & 6.52 & 7.04 & 6.83 & 6.85 \\
\hline PM (MW1) & 12 & 6.85 & 7.39 & 7.06 & 7.02 \\
\hline PM (MW2) & 12 & 7.23 & 9.18 & 8.08 & 8.07 \\
\hline Background & 11 & 7.03 & 7.49 & 7.19 & 7.17 \\
\hline
\end{tabular}


b) Dissolved Oxygen

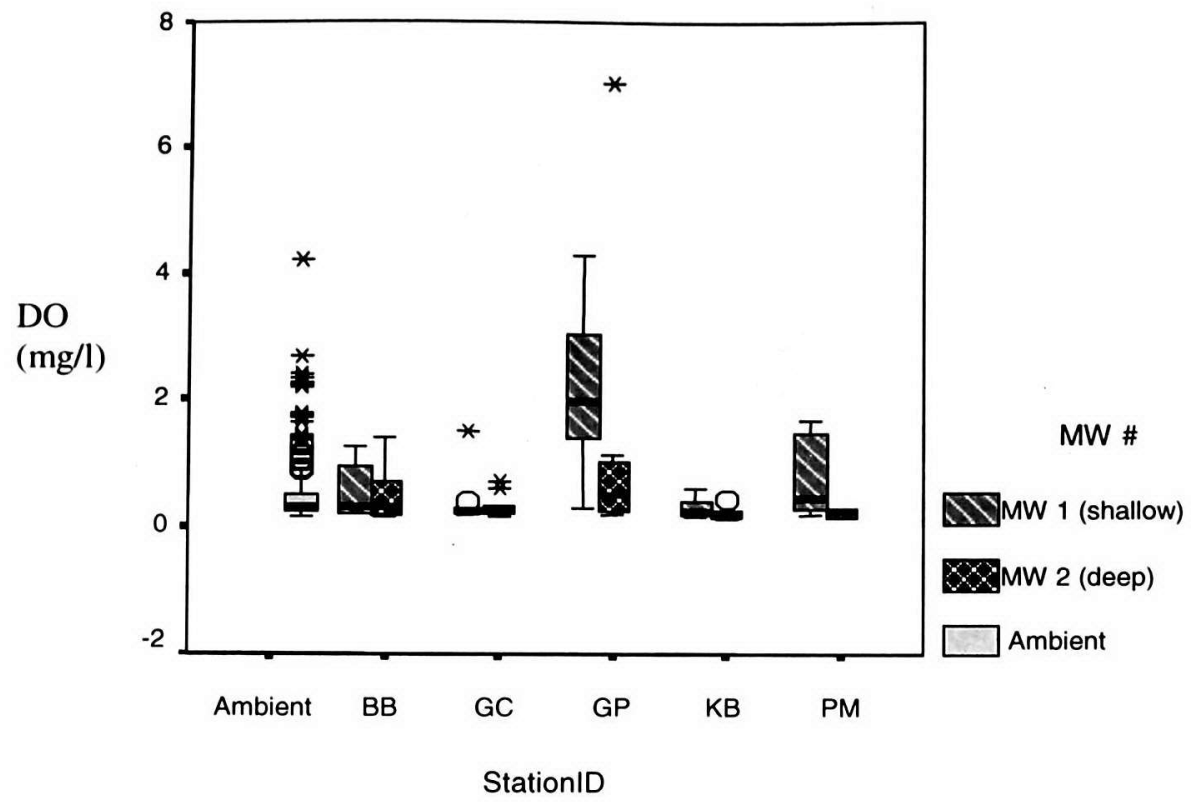

\begin{tabular}{|c|c|c|c|c|}
\hline & \multirow{2}{*}{ Station ID } & $\mathrm{N}$ & \multicolumn{3}{|c|}{ Dissolved Oxygen $(\mathrm{mg} / \mathrm{l})$} \\
\cline { 3 - 5 } & 12 & 0.21 & 1.25 & 1.09 \\
\hline BB (MW1) & 12 & 0.15 & 1.42 & 0.49 \\
\hline BB (MW2) & 9 & 0.20 & 1.50 & 0.4 \\
\hline GC (MW1) & 9 & 0.15 & 0.71 & 0.34 \\
\hline GC (MW2) & 9 & 0.30 & 1.33 & 1.31 \\
\hline GP (MW1) & 12 & 0.20 & 7.02 & 1.10 \\
\hline GP (MW2) & 12 & 0.16 & 0.62 & 0.29 \\
\hline KB (MW1) & 12 & 0.13 & 0.42 & 0.21 \\
\hline KB (MW2) & 12 & 0.20 & 1.67 & 0.83 \\
\hline PM (MW1) & 7 & 0.15 & 0.30 & 0.23 \\
\hline PM (MW2) & 6 & & & \\
\hline
\end{tabular}


c) Redox Potential

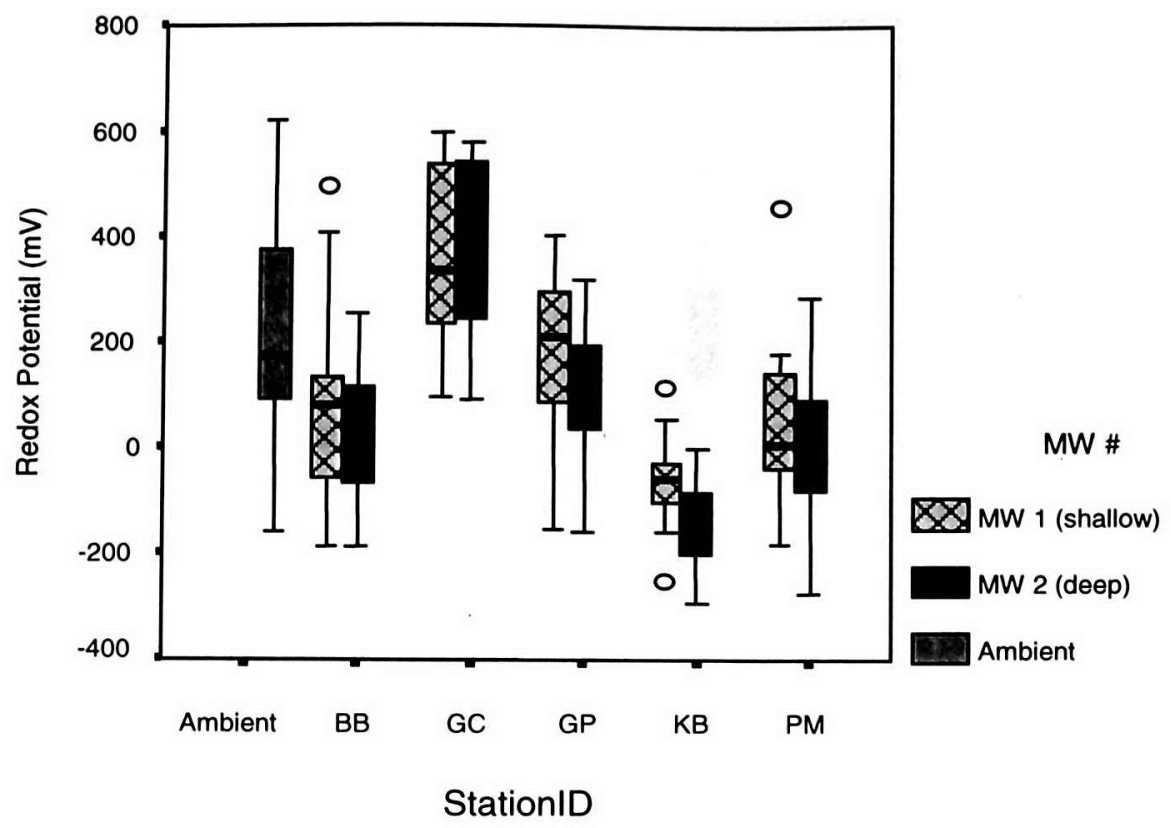

\begin{tabular}{|c|c|c|c|c|c|}
\hline \multirow{2}{*}{ Station ID } & $\mathrm{N}$ & \multicolumn{4}{|c|}{ Redox Potential (mV) } \\
\cline { 3 - 6 } BB (MW1) & 12 & -188 & 492 & 92.92 & 58.50 \\
\hline BB (MW2) & 12 & -185 & 253 & 33.00 & 61.00 \\
\hline GC (MW1) & 10 & 94 & 595 & 355.60 & 335.50 \\
\hline GC (MW2) & 10 & 92 & 578 & 397.50 & 473.00 \\
\hline GP (MW1) & 12 & -154 & 402 & 170.67 & 207.50 \\
\hline GP (MW2) & 12 & -161 & 317 & 95.42 & 103.00 \\
\hline KB (MW1) & 12 & -251 & 113 & -61.83 & -61.00 \\
\hline KB (MW2) & 12 & -293 & -1.5 & -138.29 & -108.00 \\
\hline PM (MW1) & 12 & -181 & 458 & 61.56 & 6.87 \\
\hline PM (MW2) & 12 & -275 & 286 & 16.67 & 69.00 \\
\hline Background & 11 & -159 & 134 & 22.09 & 47.00 \\
\hline
\end{tabular}


d) Salinity

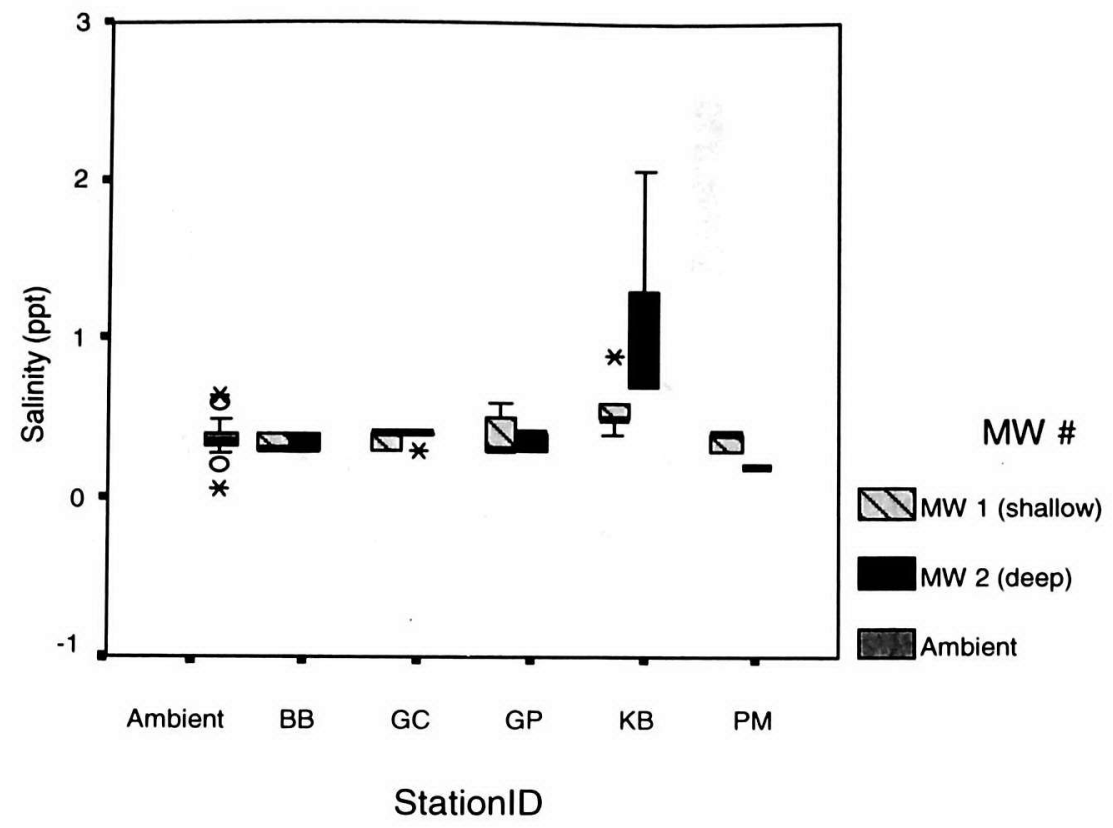

\begin{tabular}{|c|c|c|c|c|c|}
\hline \multirow[b]{2}{*}{ Station ID } & \multirow[b]{2}{*}{$\mathrm{N}$} & \multicolumn{4}{|c|}{ Salinity (ppt) } \\
\hline & & Min & Max & Mean & Median \\
\hline BB (MW1) & 9 & 0.3 & 0.4 & 0.34 & 0.3 \\
\hline BB (MW2) & 9 & 0.3 & 0.4 & 0.33 & 0.3 \\
\hline GC (MW1) & 7 & 0.3 & 0.4 & 0.36 & 0.4 \\
\hline GC (MW2) & 7 & 0.3 & 0.4 & 0.39 & 0.4 \\
\hline GP (MW1) & 9 & 0.3 & 0.6 & 0.40 & 0.3 \\
\hline GP (MW2) & 9 & 0.4 & 0.9 & 0.58 & 0.5 \\
\hline KB (MW 1) & 9 & 0.4 & 0.9 & 0.58 & 0.5 \\
\hline KB (MW2) & 9 & 0.7 & 6.1 & 1.63 & 1.1 \\
\hline PM (MW1) & 9 & 0.3 & 0.4 & 0.37 & 0.4 \\
\hline PM (MW2) & 9 & 0.2 & 0.2 & 0.20 & 0.2 \\
\hline Background & 8 & 0.2 & 0.3 & 0.25 & 0.25 \\
\hline
\end{tabular}


e) Specific Conductivity

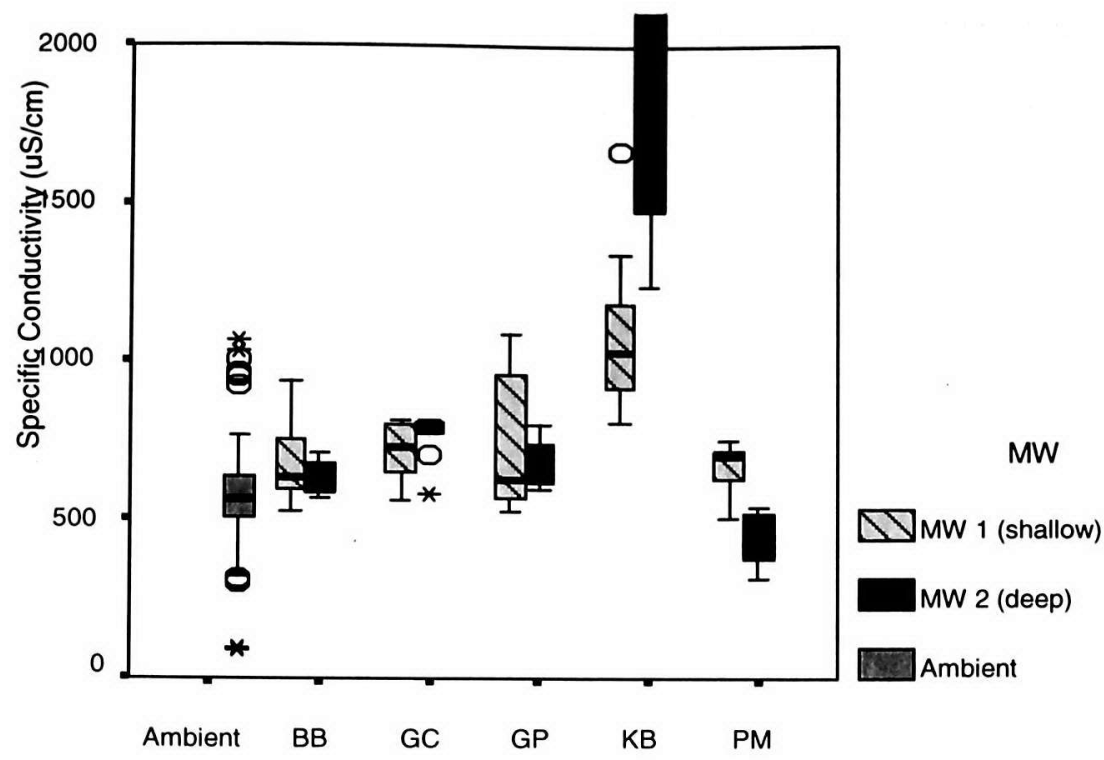

StationID

\begin{tabular}{|c|c|c|c|c|c|}
\hline \multirow{2}{*}{ Station ID } & N & \multicolumn{4}{|c|}{ Specific Conductivity (uS/cm) } \\
\cline { 3 - 6 } BB (MW1) & 12 & Min & Max & Mean & Median \\
\hline BB (MW2) & 12 & 569 & 713 & 624 & 591 \\
\hline GC (MW1) & 10 & 563 & 815 & 713 & 726 \\
\hline GC (MW2) & 10 & 577 & 810 & 762 & 784 \\
\hline GP (MW1) & 12 & 524 & 1086 & 732 & 624 \\
\hline GP (MW2) & 12 & 597 & 798 & 693 & 702 \\
\hline KB (MW1) & 12 & 808 & 1667 & 1089 & 1029 \\
\hline KB (MW2) & 12 & 1233 & 15904 & 4217 & 2241 \\
\hline PM (MW1) & 12 & 506 & 751 & 664 & 697 \\
\hline PM (MW2) & 12 & 314 & 541 & 447 & 471 \\
\hline Background & 11 & 314 & 618 & 470 & 500 \\
\hline
\end{tabular}




\section{Arsenic}

Unlike most pesticides, arsenic occurs naturally in many soils at low levels. In addition, arsenic may also be present in soils due to industrial contamination, past agricultural practices, and current application of arsenic containing fertilizer and soil amendments. In the context of this study, arsenic is routinely applied as MSMA at most golf courses. A total of 28 herbicide brands containing MSMA as the active ingredient are currently registered for use in the state of Florida.

\section{Arsenic in Soil}

Arsenic was ubiquitous in golf course soils. The data indicates that concentration of arsenic in the surficial soils at the golf courses is not reflective of naturally occurring background concentrations for Miami-Dade County which is estimated at $1.22 \mathrm{mg} / \mathrm{kg}$, [best estimate of mean] (DERM technical report, 2001 in draft). Arsenic concentration in all but one of the surficial soil samples collected for the study was above this background concentration. In addition, most of the soil samples collected during the study exceeded both the residential $(0.8 \mathrm{mg} / \mathrm{kg})$ and industrial $(3.7 \mathrm{mg} / \mathrm{kg}$ ) soil CTL. In the case of the surficial soils, $97 \%$ of samples exceeded the residential CTL and $90 \%$ exceeded the industrial. For the core samples obtained during monitoring well installation, the exceedences were $60 \%$ and $42 \%$ for the residential and industrial SCTL respectively (Table 3 ).

Highest arsenic concentrations were found in the first 2 feet of soil, and tended to decrease with depth. The number of soil samples exceeding the soil CTL indicated a strong negative linear correlation with depth (Spearman's correlation coefficient $\rho=-1.00, \alpha=0.01$ ). Arsenic was found at levels exceeding the residential and the industrial cleanup level down to the soil/water interface. Summary statistics for arsenic in soils is presented as Table 4. 
Table 3: Soil Samples Exceeding Soil CTL for Florida

\begin{tabular}{|c|c|c|c|c|c|c|c|}
\hline \multirow[b]{2}{*}{$\begin{array}{l}\text { Totals for Surficial Soil } \\
\text { Samples } 0-1 \mathrm{ft} \text {.: }\end{array}$} & \multirow{2}{*}{\begin{tabular}{|l} 
Total \\
Samples \\
30 \\
\end{tabular}} & \multicolumn{2}{|c|}{$\begin{array}{l}\text { \# samples } \\
\text { exceeding } \\
\text { residential CTL } \\
(0.8 \mathrm{mg} / \mathrm{kg})^{\dagger}\end{array}$} & \multicolumn{2}{|c|}{$\begin{array}{l}\text { \# of samples } \\
\text { exceeding } \\
\text { industrial CTL } \\
(3.7 \mathrm{mg} / \mathrm{kg})^{+}\end{array}$} & \multicolumn{2}{|c|}{$\begin{array}{l}\text { \# of samples } \\
\text { exceeding } \\
\text { leachability } \\
\text { criteria } \\
(29 \mathrm{mg} / \mathrm{kg})^{+}\end{array}$} \\
\hline & & 29 & $97 \%$ & 27 & $90 \%$ & 7 & $23 \%$ \\
\hline Soil Interval $0-2 \mathrm{ft}$. & 15 & 10 & & 8 & & 1 & \\
\hline “" $\quad 2-4 \mathrm{ft}$. & 15 & 8 & & 5 & & 0 & \\
\hline $4-6 \mathrm{ft}^{*}$ & 9 & 5 & & 4 & & 0 & \\
\hline $6-8 \mathrm{ft}$. & 3 & 2 & & 1 & & 0 & \\
\hline “ $8-10 \mathrm{ft} . * *$ & 1 & 1 & & 0 & & 0 & \\
\hline Totals for Core Samples: & 43 & 26 & $60 \%$ & 18 & $42 \%$ & 1 & $2 \%$ \\
\hline Total Percent Exceedences: & & $75 \%$ & & $62 \%$ & & $11 \%$ & \\
\hline
\end{tabular}

${ }^{\dagger}$ FDEP Soil Cleanup Target Level (Chapter 62-777, Florida Administrative Code)

* Mean groundwater table interval

** Maximum water table depth

Analysis of arsenic concentration in the soil profile using the Kruskal-Wallis test indicated no significant differences between golf courses either for the entire soil profile or for discreet depth intervals. Multiple comparison analysis of surficial soil arsenic concentration between golf courses (Tukey-Type test) indicated significant differences when data from Greynolds Park Golf Course was compared with Key Biscayne Golf Course as well as with Golf Club of Miami. The other population comparisons indicated no significant differences. 
Table 4: Summary Statistics for Soil Arsenic Concentration (mg/kg)

\begin{tabular}{|c|c|c|c|c|c|c|c|}
\hline & \multirow[t]{2}{*}{$\mathbf{N}$} & \multirow[t]{2}{*}{ Median } & \multirow[t]{2}{*}{ Range } & \multirow[t]{2}{*}{ Minimum } & \multirow[t]{2}{*}{ Maximum } & \multicolumn{2}{|c|}{ Percentiles } \\
\hline & & & & & & $25^{\text {th }}$ & $75^{\text {th }}$ \\
\hline Soil Profile* & 43 & 1.19 & 17.09 & 0.1 & 17.19 & 0.49 & 5.27 \\
\hline \begin{tabular}{|l|} 
Surficial \\
Soils
\end{tabular} & 31 & 15.10 & 54.00 & 0.80 & 54.80 & 9.90 & 28.80 \\
\hline All Soils* & 74 & 5.6 & 54.70 & 0.1 & 54.80 & 0.87 & 14.28 \\
\hline
\end{tabular}

* One data point with a value over 9 times the interquartile range was excluded from the analysis

Arsenic in Groundwater

Shallow wells ( $7-12$ feet)

Arsenic was detected in 14 of the 15 shallow groundwater wells with a median concentration being $27.5 \mathrm{ug} / \mathrm{l}$. Thirty-two percent of shallow ground water samples exceeded the Florida groundwater CTL (50 ug/l) for arsenic in groundwater (Chapter 62-777, Florida Administrative Code). This is consistent with the data from golf courses in other parts of Florida where twentynine percent of groundwater samples from nine golf courses in North and Central Florida exceeded the CTL for arsenic (Swancar, 1996). The data was compared to a proposed MCL of $10 \mathrm{ug} / \mathrm{l}$ based on federal initiatives currently under consideration. Seventy-six percent of the shallow groundwater samples would exceed the proposed MCL of $10 \mathrm{ug} / \mathrm{l}$ (Table 5).

Analysis of the groundwater data from the shallow wells indicated that there were no statistically significant differences in shallow groundwater arsenic concentration across the five golf courses. However, when the data from shallow wells were compared with background arsenic data a significant difference was indicated. The implication is that arsenic concentration in the shallow wells at golf courses are not reflective of background conditions however, they appear to be 
reflective of concentrations that might be typically be encountered at golf courses. There is a strong positive correlation between arsenic concentration at the soil/water interface and arsenic in shallow groundwater (Spearman's correlation coefficient $\rho=0.708, \alpha=0.01$ ). However, a comparative analysis of the data from soil samples obtained during monitoring well installation versus groundwater data obtained from the shallow wells during the first quarter sampling event indicates that arsenic concentration in groundwater is not correlated with arsenic concentration in shallow substrate (0-2ft) soils (Spearman's correlation coefficient $\rho=0.304, \alpha=0.01$ ).

Overall median arsenic concentration in shallow well decreased to $20.4 \mathrm{ug} / \mathrm{l}$ (from $27.5 \mathrm{ug} / \mathrm{l}$ ) with the addition of data from a follow up sampling event in April 1999. However, there was no consistent indication of a tendency to a reduction in groundwater arsenic concentrations since the concentrations in some wells increased while some wells showed a decline.

Deep Wells (21-28 feet)

There were no exceedences of the current arsenic MCL in groundwater from the deep wells however; approximately $18 \%$ of the samples would exceed the $10 \mathrm{ug} / \mathrm{l} \mathrm{MCL}$ being proposed based on current federal initiatives (Table 6). As in the case of the shallow wells, groundwater arsenic concentration in the deep wells exhibited no significant differences (Kruskal Wallis test) when compared across golf courses. In addition, arsenic concentrations in deep (21-28 ft) groundwater at golf courses were not significantly different (Kruskal Wallis test) from background arsenic concentrations from wells of similar depth in the AWQM network. Data from the March 1999 sampling event indicated no significant change in arsenic concentration in groundwater from deep wells. 
Table 5: Summary Statistics for Shallow Groundwater Arsenic Concentration

\begin{tabular}{|c|c|c|c|c|c|c|}
\hline \multirow[t]{2}{*}{ Golf Course } & \multirow{2}{*}{$\begin{array}{l}\# \\
\text { Samples } \\
(\mathrm{n})\end{array}$} & \multicolumn{3}{|c|}{ Arsenic Concentration (ug/l) } & \multicolumn{2}{|c|}{ (\#) and $\%$ of samples exceeding } \\
\hline & & Min & $\operatorname{Max}$ & Median & $\mathrm{MCL}$ (50ug/l) & $\begin{array}{l}\text { Proposed } \\
\text { MCL } \\
\text { (10ug/l) }\end{array}$ \\
\hline Briar Bay & 12 & 1.00 & 815 & 2.5 & (5) $41.7 \%$ & (5) $41.7 \%$ \\
\hline Palmetto & 12 & 1.00 & 10.5 & 56.0 & (1) $8.3 \%$ & (6) $50.0 \%$ \\
\hline Key Biscayne & 12 & 14.00 & 392.00 & 14.00 & (4) $33.3 \%$ & (12) $100 \%$ \\
\hline $\begin{array}{l}\text { Golf Club of } \\
\text { Miami }\end{array}$ & 12 & 12.00 & 123.00 & 30.00 & (4) $33.3 \%$ & (12) $100 \%$ \\
\hline Greynolds Park & 12 & 10.00 & 243.00 & 30.00 & (5) $41.7 \%$ & (11) $91.7 \%$ \\
\hline Total & 60 & 1.00 & 815.00 & 27.50 & (19) $31.7 \%$ & (44) $76.6 \%$ \\
\hline Background* & 10 & 1.00 & 5.00 & 1.00 & (0) $0 \%$ & (0) $0 \%$ \\
\hline $\begin{array}{l}\text { Historical } \\
\text { Background** }\end{array}$ & 22 & 1.00 & 13.9 & 2.00 & $(0) 0 \%$ & (1) $4.5 \%$ \\
\hline
\end{tabular}

* Data from background wells sampled concurrently with golf course wells

** Historical data from the AWQM network

Table 6: Summary Statistics for Deep (21-28 ft) Groundwater Arsenic Concentration

\begin{tabular}{|l|l|l|l|l|l|}
\hline \multirow{2}{*}{ Type of Site } & \multirow{2}{*}{$\begin{array}{l}\text { \# Samples } \\
(\mathrm{n})\end{array}$} & \multicolumn{3}{|l|}{ Arsenic Concentration (ug/l) } & $\begin{array}{l}\text { \% of samples that } \\
\text { would exceed an } \\
\text { MCL of 10 ug/1* }\end{array}$ \\
\cline { 3 - 6 } & & Min & Max & Median & $33.3 \%$ \\
\hline Briar Bay & 12 & 1.00 & 44.00 & 1.00 & $0 \%$ \\
\hline Palmetto & 12 & 1.00 & 6.00 & 1.00 & $16.7 \%$ \\
\hline Key Biscayne & 12 & 1.00 & 11.30 & 1.00 & $0 \%$ \\
\hline Golf Club & 12 & 1.00 & 4.00 & 1.00 & $25 \%$ \\
\hline Greynolds Park & 12 & 1.00 & 19.00 & 3.00 & $18 \%$ \\
\hline Total & 60 & 1.00 & 44.00 & 1.00 & \\
\hline
\end{tabular}


Arsenic Levels at Different Golf Course Areas

\section{Mix/Load Sites}

Monitoring sites were located at or in the vicinity of the agrichemical mixing and loading areas of all the participating golf courses. Data from mix load sites is analyzed with the caveat that accessibility constraints at Golf Club of Miami and Key Biscayne Golf Course resulted in the wells being sited at less than optimal distances ( $200 \mathrm{ft}$ and $82 \mathrm{ft}$ respectively) from the mix load sites. At Palmetto Golf Course wells were place adjacent to a new mix/load center. Based on the foregoing, the data from the mix/load sites at Briar Bay and Greynolds Park Golf Course are considered to be most representative of historical impact and traditional mix/load sites. Data from all mix/load sites are presented in Table $7 \mathrm{a}$ and Figure 10a-d however only data from Briar Bay and Greynolds Park Golf course (Table 7b) are used in the discussions.

All soil samples from Briar Bay and Greynolds Park golf courses exceeded the soil residential CTL. The soil sample collected from the 0-2 $\mathrm{ft}$ interval of the mix/load site at the Briar Bay Golf Course (during monitoring well installation) had an arsenic concentration of $120.65 \mathrm{mg} / \mathrm{kg}$ which was over nine times the interquartile range for soil samples obtained during the study. While this data point was considered environmentally valid it was considered a statistical outlier and was not included in data analysis. There were not enough data points to facilitate a statistical analysis of arsenic concentration in soils at $\mathrm{mix} / \mathrm{load}$ sites.

The shallow ground water samples from the mix/load sites at Briar Bay and Greynolds Park consistently exceeded the arsenic MCL with the median concentrations at $519 \mathrm{ug} / \mathrm{l}$ and $181 \mathrm{ug} / \mathrm{l}$ respectively. Arsenic was elevated above and significantly different from background in the samples from the deep wells at Briar Bay and Greynolds Park but the MCL was not exceeded. 
Table 7a: Summary Statistics for Samples Obtained from Mix/load Sites by Sample Matrix (all mix load sites)

\begin{tabular}{|l|l|l|l|l|l|l|l|}
\hline \multirow{2}{*}{$\begin{array}{l}\text { Sample } \\
\text { Type25 }\end{array}$} & \multirow{2}{*}{ Depth } & \multirow{2}{*}{$\mathrm{N}$} & \multicolumn{2}{|l|}{ Arsenic Concentration } & \multicolumn{2}{|c|}{ Percentile } \\
\cline { 4 - 8 } & & & Min & Max & Median & $25^{\text {th }}$ & $75^{\text {th }}$ \\
\hline \multirow{2}{*}{ Soil } & & & & & & & \\
\hline
\end{tabular}

* One data point with a value over 9 times the interquartile range was excluded from the analysis

Table 7b: Summary statistics for samples obtained from mix load site at Briar Bay and Greynolds Park Golf Course

\begin{tabular}{|c|c|c|c|c|c|c|c|c|}
\hline \multirow[t]{2}{*}{ Site } & \multirow[t]{2}{*}{$\begin{array}{l}\text { Sample } \\
\text { type }\end{array}$} & \multirow[t]{2}{*}{ Depth } & \multirow[t]{2}{*}{$n$} & \multicolumn{3}{|c|}{$\begin{array}{l}\text { Arsenic Concentration } \\
\text { soils }(\mathrm{mg} / \mathrm{kg}) \text { groundwater } \\
\text { (ug/l) }\end{array}$} & \multicolumn{2}{|c|}{ Percentile } \\
\hline & & & & Min & $\operatorname{Max}$ & Median & $25^{\text {th }}$ & $75^{\text {th }}$ \\
\hline \multirow{2}{*}{$\begin{array}{l}\text { Briar } \\
\text { Bay }\end{array}$} & \multirow[t]{2}{*}{ Soil } & Surficial & 2 & 8.3 & 9.6 & 8.95 & 8.63 & 9.28 \\
\hline & & Core* & 1 & \multicolumn{3}{|l|}{4.52} & \multicolumn{2}{|l|}{ na } \\
\hline \multirow{2}{*}{$\begin{array}{l}\text { Briar } \\
\text { Bay }\end{array}$} & \multirow{2}{*}{$\begin{array}{l}\text { Ground } \\
\text { water }\end{array}$} & Shallow & 4 & 455.00 & 815.00 & 519.00 & 470.75 & 741.25 \\
\hline & & Deep & 4 & 15.00 & 44.00 & 24.85 & 17.18 & 39.50 \\
\hline \multirow{2}{*}{$\begin{array}{l}\text { Greyn } \\
\text { olds } \\
\text { Park }\end{array}$} & \multirow[t]{2}{*}{ Soil } & Surficial & 1 & \multicolumn{3}{|c|}{5.6} & \multicolumn{2}{|l|}{ na } \\
\hline & & Core & 4 & 3.72 & 9.10 & 7.26 & 5.50 & 8.58 \\
\hline \multirow{2}{*}{$\begin{array}{l}\text { Greyn } \\
\text { olds } \\
\text { Park }\end{array}$} & \multirow{2}{*}{$\begin{array}{l}\text { Ground } \\
\text { water }\end{array}$} & Shallow & 4 & 128.00 & 243.00 & 181.00 & 129.75 & 239.00 \\
\hline & & Deep & 4 & 3.00 & 19.00 & 9.80 & 4.65 & 16.75 \\
\hline
\end{tabular}


Except for shallow groundwater from the mix/load sites at Key Biscayne data from the March 1999 sampling event were within the ranges of concentration experienced during 1997

Figure $10 \mathrm{a}-\mathrm{d}$ : Arsenic concentration in soil and groundwater from mix/load sites

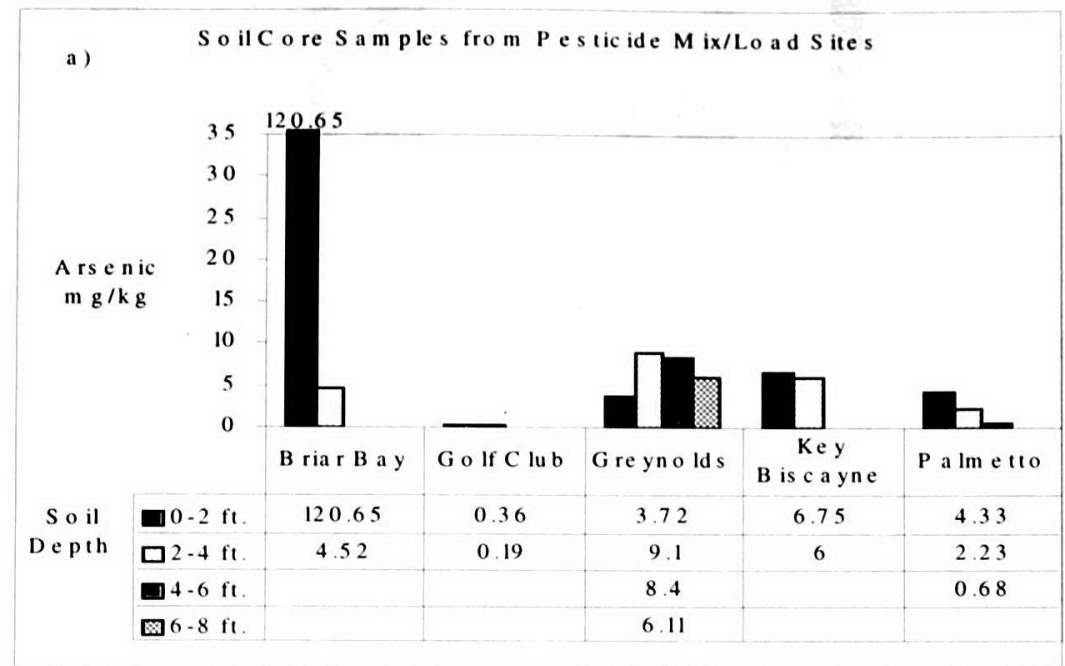

b) $S$ urficial $S$ oil $S$ am ples from $P$ estic ide $M$ ix/Lo ad $S$ ite $s$

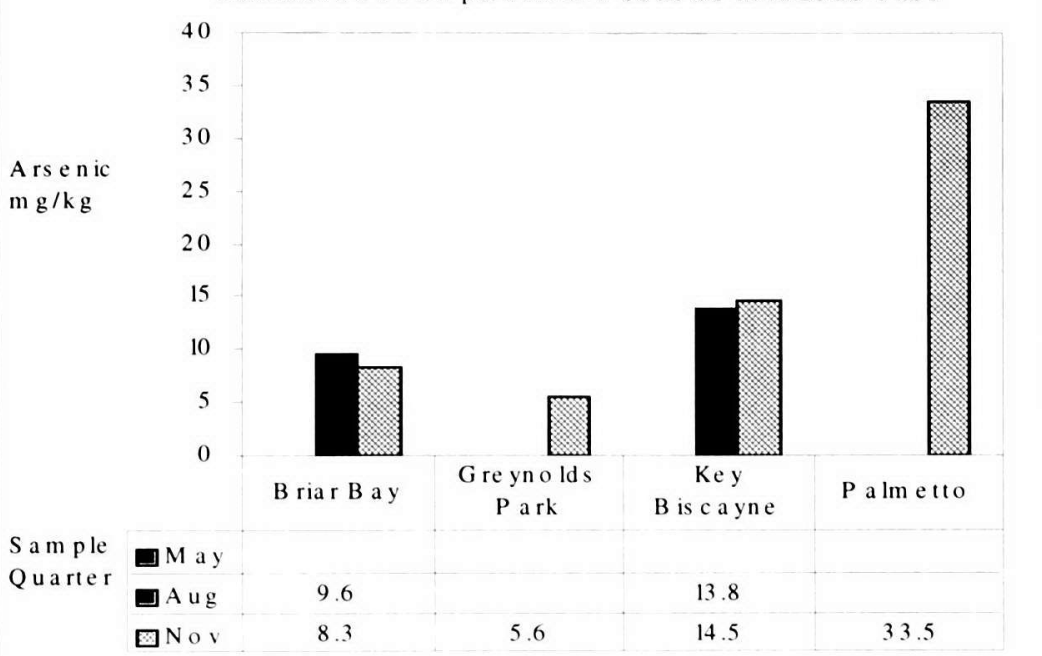




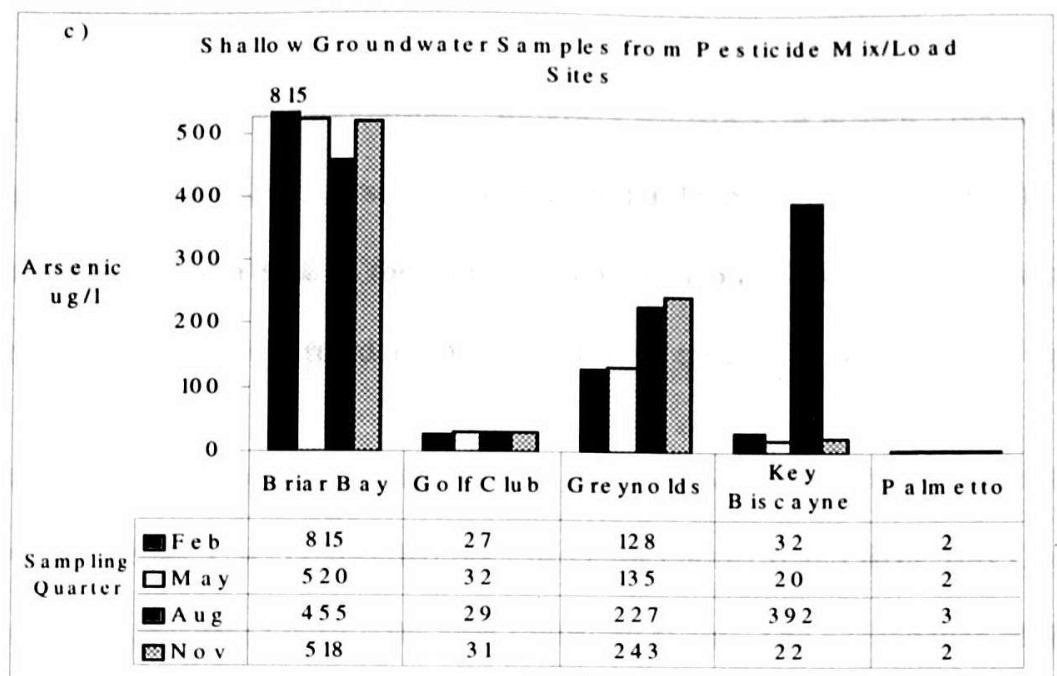

d) Deep Groundwater Samples from Pesticide Mix/Load Sites

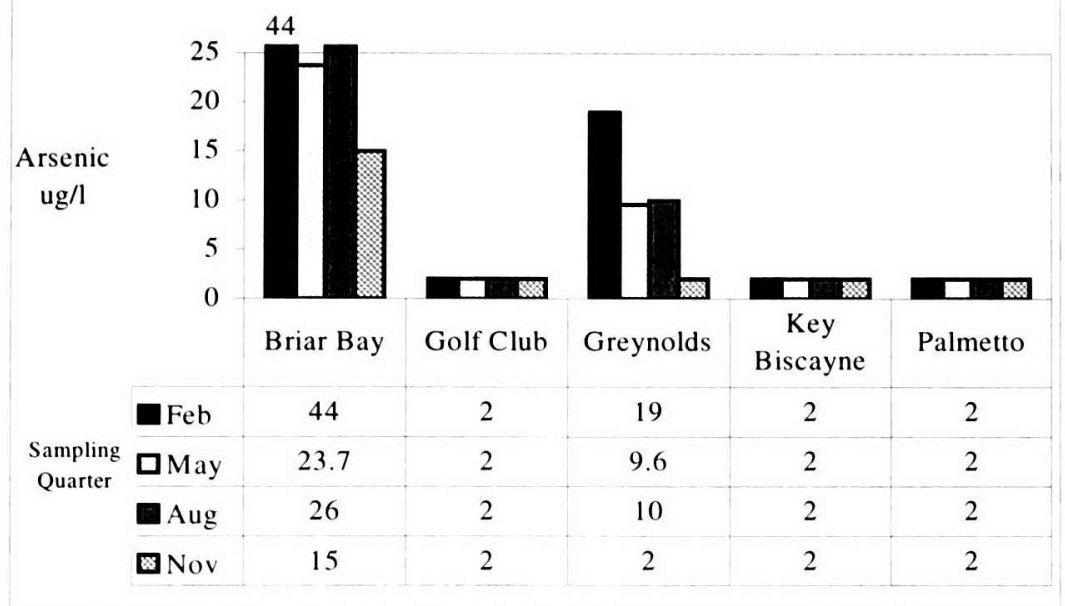




\section{Fairways}

Four fairway sites were monitored. Summary statistics for arsenic concentration at fairway sites are provided in Table 8 . Arsenic was detected at levels exceeding both the residential and industrial criteria in $36 \%$ of the soil core samples from fairway sites. Arsenic levels in surficial soils exceeded both the residential and industrial criteria in all samples (Figure $11 \mathrm{a}$ and $\mathrm{b}$ ).

Arsenic was elevated over background in the shallow groundwater at several fairway sites, however, the MCL was exceeded only twice; at Palmetto and Briar Bay Golf Courses. Both exceedences occurred during the first sampling event. The exceedence of the MCL at fairway \#4 at Briar Bay Golf Course during the first sampling event was inconsistent with the trace levels detected in the subsequent samples (Figure 11c). Arsenic was detected in trace amounts in $31 \%$ of the samples from deep wells (Figure 11d). Groundwater arsenic concentration at fairways during 1999 was generally within the range of concentrations experienced in 1997.

Table 9: Summary Statistics for Soils and Groundwater at Fairway Sites

\begin{tabular}{|l|l|l|l|l|l|l|l|}
\hline \multirow{2}{*}{$\begin{array}{l}\text { Sample } \\
\text { Type }\end{array}$} & \multirow{2}{*}{ Depth } & $\mathrm{n}$ & \multicolumn{5}{|c|}{ Arsenic Concentration } \\
\cline { 4 - 8 } & & & Minimum & Maximum & Median & $\begin{array}{l}25^{\text {th }} \\
\text { percentile }\end{array}$ & $\begin{array}{l}75^{\text {th }} \\
\text { percentile }\end{array}$ \\
\hline $\begin{array}{l}\text { Soil } \\
(\mathrm{mg} / \mathrm{kg})\end{array}$ & Surficial & 9 & 13.10 & 34.6 & 27.5 & 14.4 & 29.1 \\
\cline { 2 - 8 } & Core & 11 & 0.1 & 14.28 & 0.34 & 0.1 & 7.85 \\
\hline $\begin{array}{l}\text { Water } \\
(\mathrm{ug} / \mathrm{l})\end{array}$ & Shallow & 16 & 1.00 & 56.00 & 17.75 & 1.00 & 29.85 \\
\cline { 2 - 8 } & Deep & 16 & 1.00 & 6.00 & 1.00 & 1.00 & 3.00 \\
\hline
\end{tabular}


Figure 11 a-d: Arsenic concentration in soil and groundwater at fairway sites

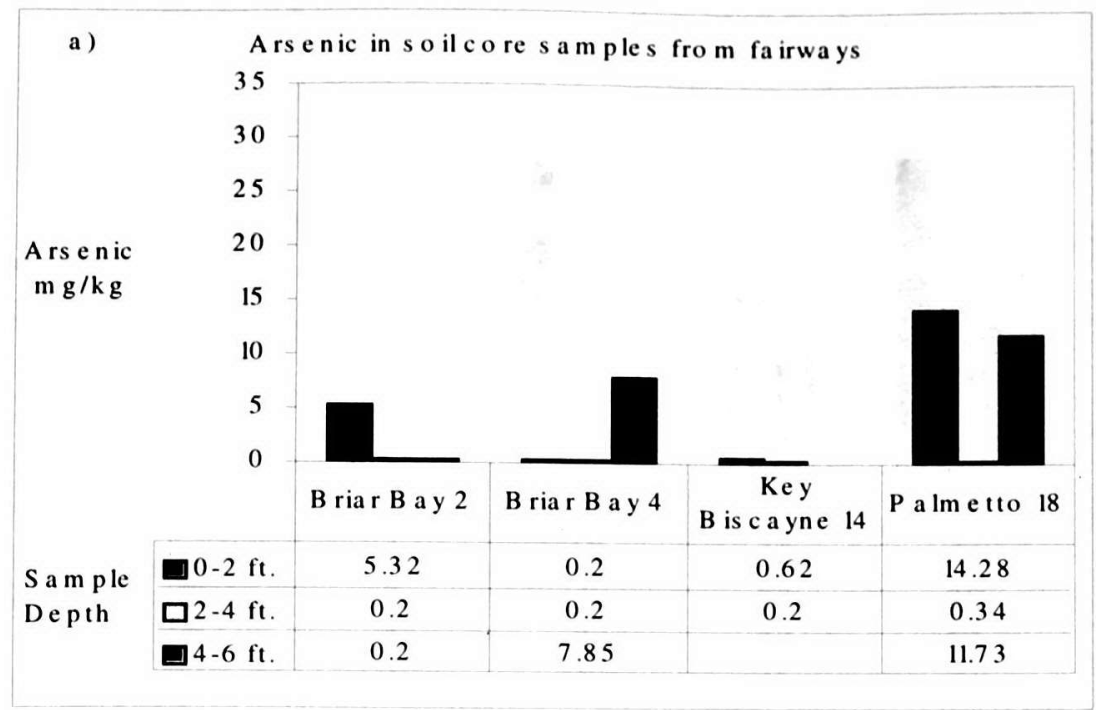

b) A rse $\mathrm{nic}$ in surfic ials o ils o $\mathrm{n}$ fa irways

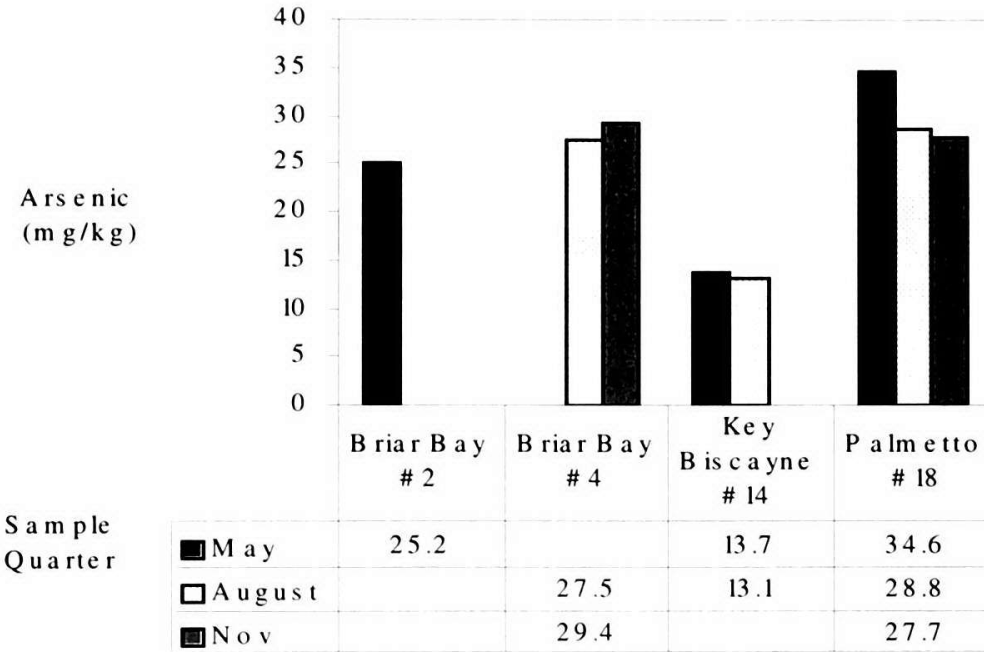




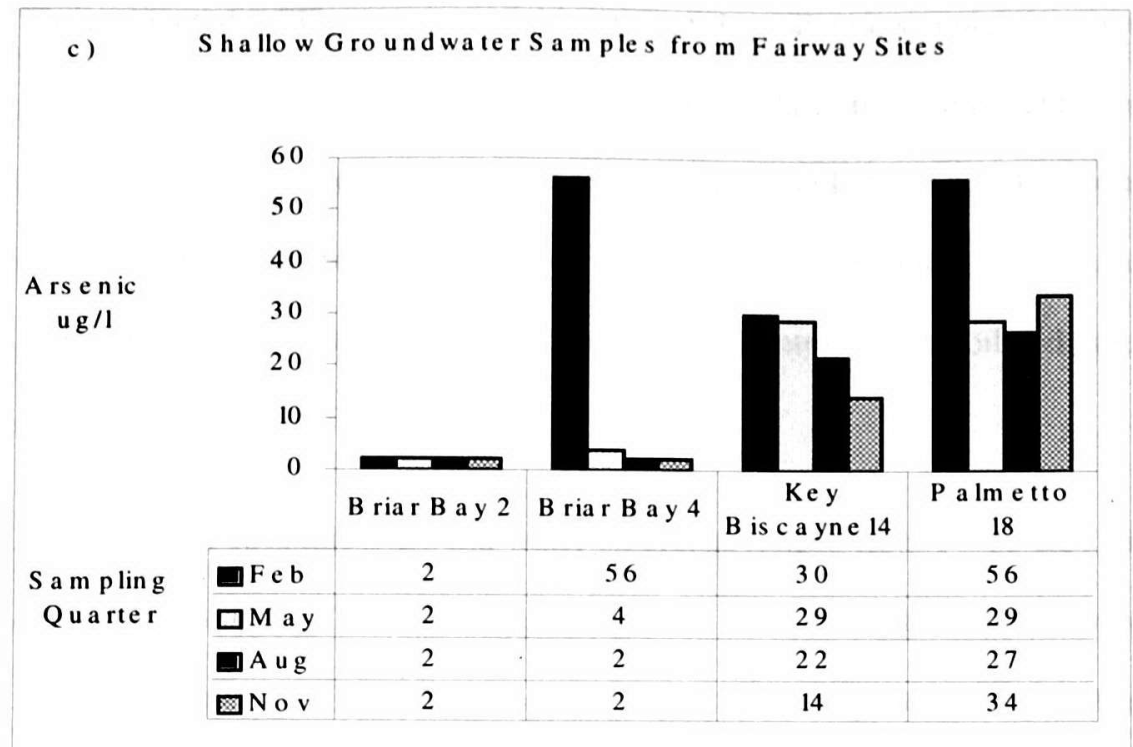

d)

Deep Groundwater Samples from Fairway Sites

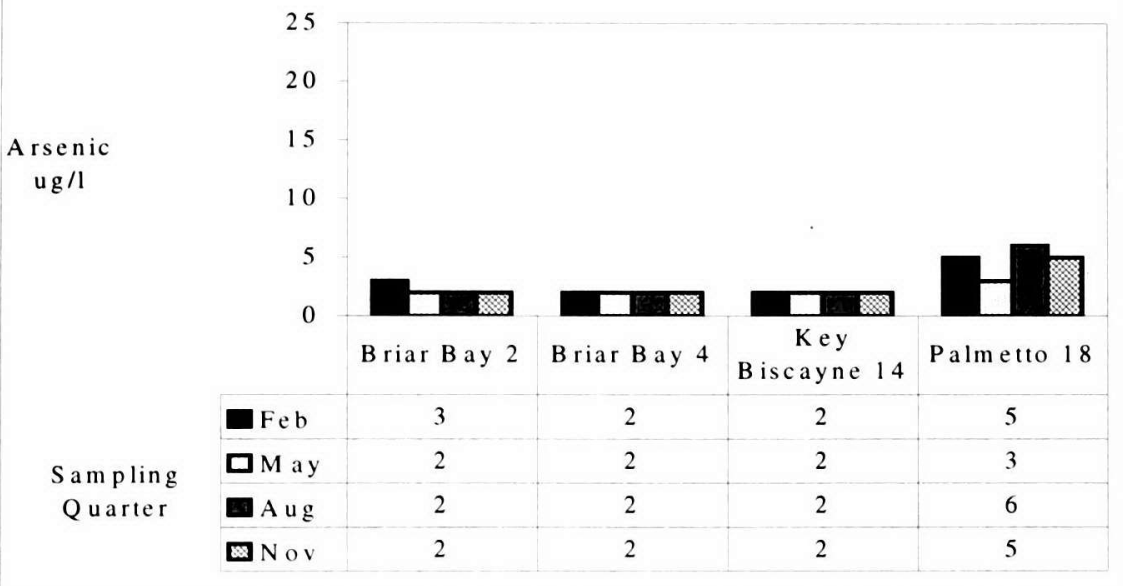




\section{Arsenic Levels at Green Sites}

The residential SCTL was exceeded in $66 \%$ of the soil core samples from green sites. Only one such sample exceeded the industrial level (Figure 12a.). In contrast all but one surficial, soil sample from greens exceeded the residential criteria and $50 \%$ exceeded the industrial criteria (Figure 12b.). The green at Greynolds Park Golf Course had the highest arsenic levels for surficial soils. Summary statistics for arsenic concentrations in soil and groundwater at green sites are provided in Table 9.

Arsenic levels in shallow ground water on greens ranged from $7-55 \mathrm{ug} / \mathrm{l}$ with a single exceedence of the MCL occurring at Greynolds Park during the third sampling episode (August). Arsenic was detected in trace amounts at some of the deep wells. (Figure 12c, d). Data obtained from green sites during the 1999 sampling event were consistent with the 1997 data except at Greynolds Park Golf Course. Arsenic concentration in shallow groundwater declined to BDL in 1999.

Table 9: Summary Statistics for Arsenic at Green Sites

\begin{tabular}{|c|c|c|c|c|c|c|c|}
\hline \multirow{2}{*}{$\begin{array}{l}\text { Sample } \\
\text { Type }\end{array}$} & \multirow[t]{2}{*}{ Depth } & \multirow[t]{2}{*}{$n$} & \multicolumn{3}{|c|}{ Arsenic Concentration } & \multirow[t]{2}{*}{$25^{\mathrm{th}}$ percentile } & \multirow{2}{*}{$\begin{array}{l}75^{\text {th }} \\
\text { percentile }\end{array}$} \\
\hline & & & Minimum & Maximum & Median & & \\
\hline \multirow{2}{*}{$\begin{array}{l}\text { Soil } \\
(\mathrm{mg} / \mathrm{kg})\end{array}$} & Surficial & 7 & 0.8 & 40.4 & 4.30 & 1.80 & 32.8 \\
\hline & Core & 9 & 0.1 & 6.0 & 1.11 & 0.49 & 2.38 \\
\hline \multirow{2}{*}{$\begin{array}{l}\text { Water } \\
(\mathrm{ug} / \mathrm{l})\end{array}$} & Shallow & 12 & 6.5 & 55.0 & 13.55 & 10.5 & 23.97 \\
\hline & Deep & 12 & 1.00 & 4.0 & 1.00 & 1.00 & 3.75 \\
\hline
\end{tabular}


Figure 12a-d: Arsenic in soil and groundwater at green sites

a)

Soil Core Samples from Greens Sites

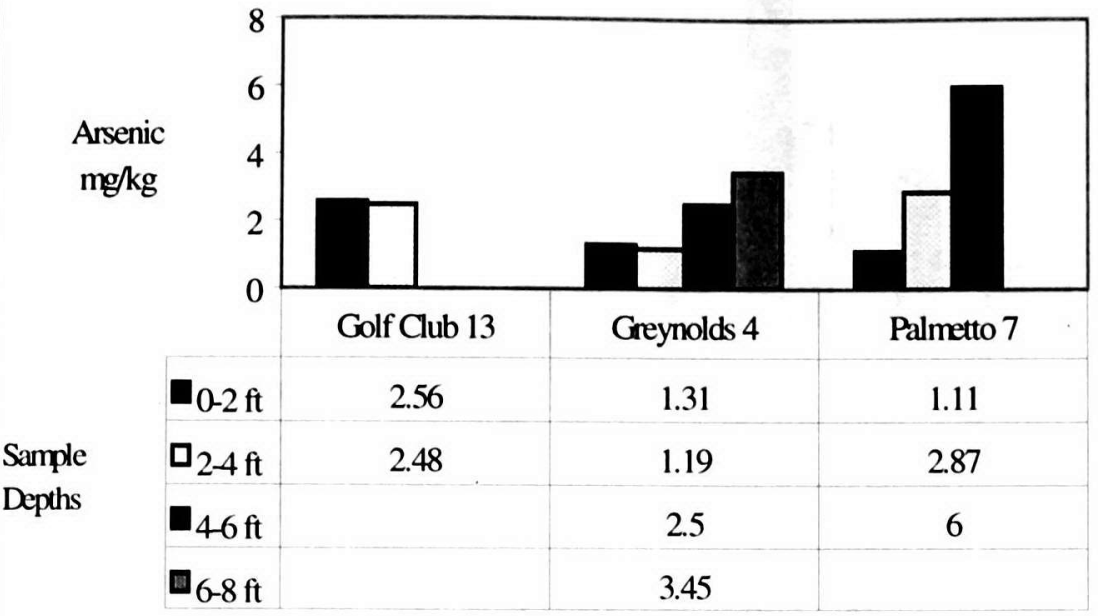

b)

Surficial Soil Samples from Green Sites

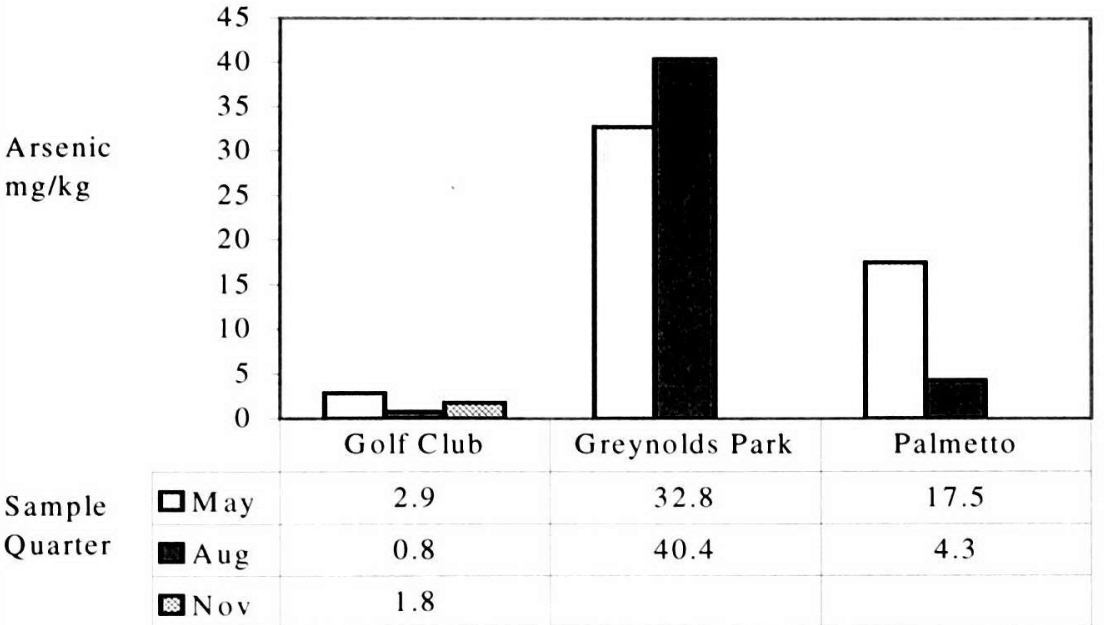


c)

$S$ hallow Groundwater $S$ a m ples from Green $S$ ites

A rs e $\mathrm{n}$ ic

u $\mathrm{g} / \mathrm{l}$

$S$ a $m p$ lin $g$

$Q$ uarter

\begin{tabular}{|l|c|c|c|}
\hline$\square$ F b & 17 & 12 & 25 \\
\hline$\square \mathrm{M}$ a y & 12 & 21 & 9 \\
\hline $\mathbf{A ~ u g}$ & 12 & 55 & 12 \\
\hline $\mathrm{Nov}$ & 15 & 32 & 7 \\
\hline
\end{tabular}

Deep Groundwater $S$ a m ples fro $m G$ reen $S$ ites

d)

A rsenic

$\mathrm{ug} / \mathrm{l}$

S a m pling

Quarter

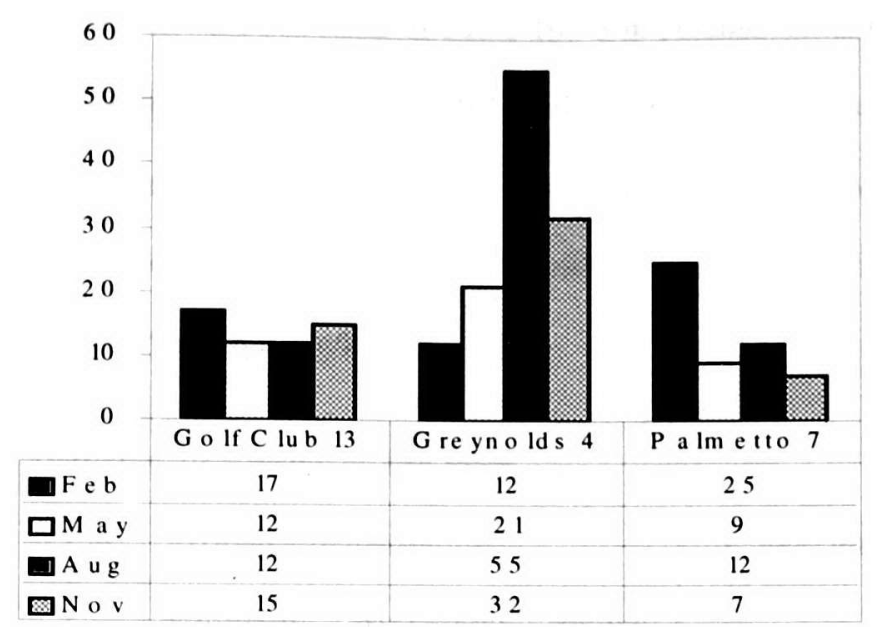

10

8

6

4

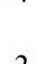

0
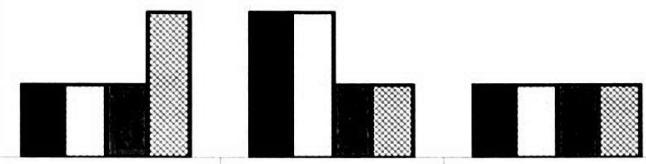

Go lf C lub 13
P a lm e t to 7 2

\begin{tabular}{|l|l|l|l|}
\hline Feb & 2 & 4 & 2 \\
\hline$\square$ a a & 2 & 4 & 2 \\
\hline$\square$ A u & 2 & 2 & 2 \\
\hline №v & 4 & 2 & 2
\end{tabular}


Arsenic Levels at Tee Sites

Three tee sites were monitored during the study, summary statistics for arsenic concentrations in soil and groundwater at tee sites are provided in Table 10. Soil arsenic levels from core samples ranged from BDL to $17.19 \mathrm{mg} / \mathrm{kg}$ with $38 \%$ and $30 \%$ of the samples exceeding the residential and industrial soil cleanup target levels, respectively (Figure 13a). Arsenic levels in the surficial soil samples at the tee sites consistently exceeded both residential and industrial criteria (Figure 13b). Values ranged from 9.9 to $54.8 \mathrm{mg} / \mathrm{kg}$.

Table 10: Summary Statistics for Arsenic at Tee Sites

\begin{tabular}{|c|c|c|c|c|c|c|c|}
\hline \multirow{2}{*}{$\begin{array}{l}\text { Sample } \\
\text { Type }\end{array}$} & \multirow[t]{2}{*}{ Depth } & \multirow[t]{2}{*}{$\mathrm{N}$} & \multicolumn{3}{|c|}{ Arsenic Concentration } & \multirow[t]{2}{*}{$25^{\text {th }}$ percentile } & \multirow{2}{*}{$\begin{array}{l}75^{\text {th }} \\
\text { percentile }\end{array}$} \\
\hline & & & Minimum & Maximum & Median & & \\
\hline \multirow{2}{*}{$\begin{array}{l}\text { Soil } \\
(\mathrm{mg} / \mathrm{kg})\end{array}$} & Surficial & 9 & 9.9 & 54.8 & 17.00 & 13.1 & 26.95 \\
\hline & Core & 10 & 0.1 & 17.19 & 1.69 & 0.36 & 4.32 \\
\hline \multirow{2}{*}{$\begin{array}{l}\text { Water } \\
(\mathrm{ug} / \mathrm{l})\end{array}$} & Shallow & 12 & 10.5 & 123.0 & 81.75 & 18.25 & 23.97 \\
\hline & Deep & 12 & 1.00 & 11.3 & 3.00 & 1.00 & 8.50 \\
\hline
\end{tabular}

Figure 13a and 13b: Arsenic concentration in soil core and surficial soil samples at tee sites

a )

Arsenic
$\mathrm{mg} / \mathrm{kg}$

So il Core $S$ a $m$ ples fro $m$ Tee $S$ ites

Depth
$0-2 \mathrm{ft}$.
$\square 2-4 \mathrm{ft}$.
$\square 4-6 \mathrm{ft}$.

$0-2 \mathrm{ft}$.
$\square 2-4 \mathrm{ft}$.
$\square 4-6 \mathrm{ft}$.

\begin{tabular}{l|l}
$\square 0-2 \mathrm{ft}$. & 5.22 \\
$\square 2-4 \mathrm{ft}$. & 3.8 \\
$\square 4-6 \mathrm{ft}$. &
\end{tabular}

\begin{tabular}{l|l}
$\square 0-2 \mathrm{ft}$. & 5.22 \\
$\square 2-4 \mathrm{ft}$. & 3.8 \\
$\square 4-6 \mathrm{ft}$. &
\end{tabular}

国 6 -8

5

5

20

5

0
G o If C lu b 10

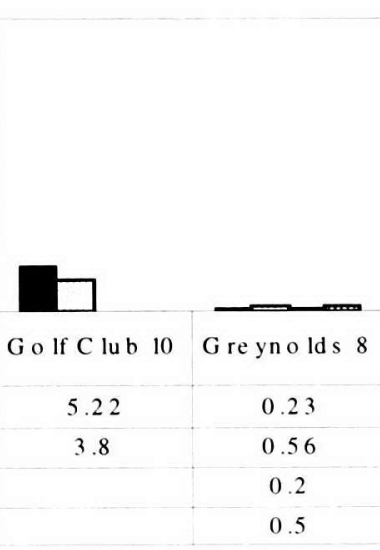

0.5

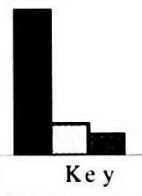

$B$ is c a yne 18

17.19

3.9

2.38 
b)

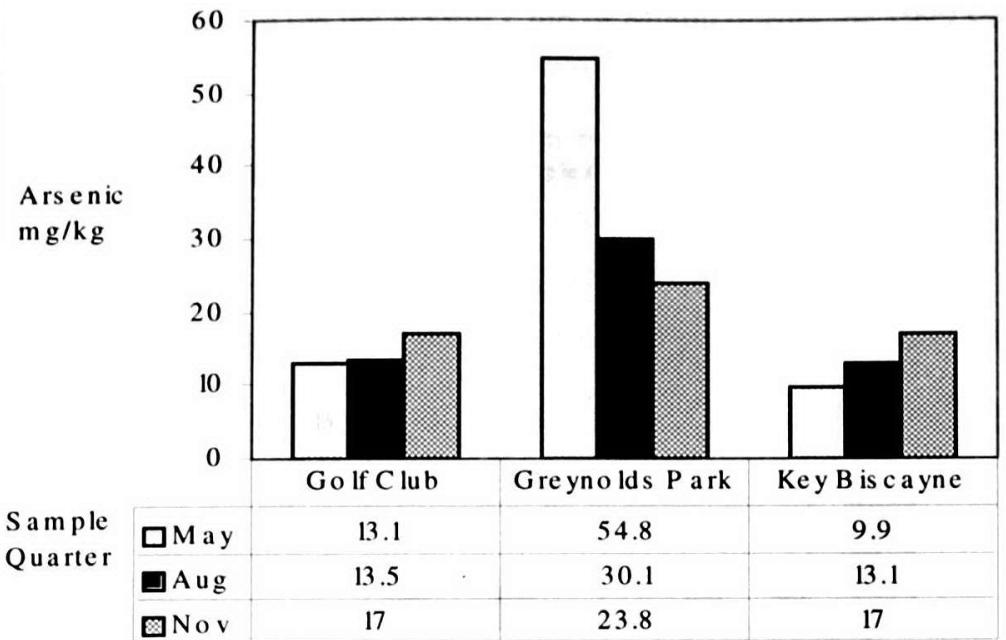

Shallow ground water samples at Golf Club of Miami consistently exceeded the ground water standard and at Key Biscayne all but one sample (February) exceeded the standard (Figure 13c and $13 \mathrm{~d})$.

Figure 13c and 13d: Arsenic in groundwater (shallow and deep) at tee sites

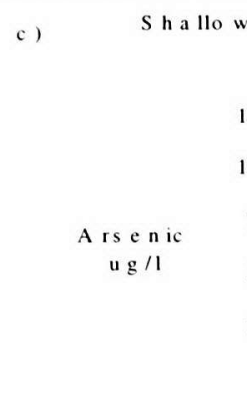

$S$ a $m$ pling

$Q$ u a rte $r$

\begin{tabular}{l|c}
$\square \mathrm{Feb}$ & 83 \\
\hline $\mathrm{M} \mathrm{ay}$ & 86 \\
$\square \mathrm{Aug}$ & $12 \mathrm{I}$ \\
$\square \mathrm{Nov}$ & 123
\end{tabular}
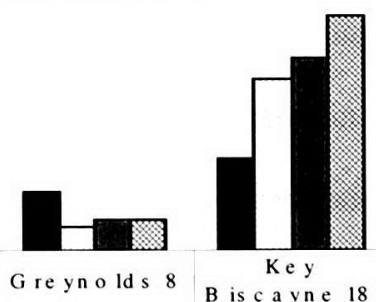

\begin{tabular}{|c|c|}
\hline 28 & 44 \\
\hline 11 & 81 \\
\hline 14 & 92 \\
\hline 15 & 112 \\
\hline
\end{tabular}


Arsenic was elevated above background for deep groundwater at Key Biscayne Golf Course tee site. Arsenic concentration was elevated above the 1997 levels in the shallow groundwater sample obtained from the tee at Golf Club of Miami during the 1999 sampling event.

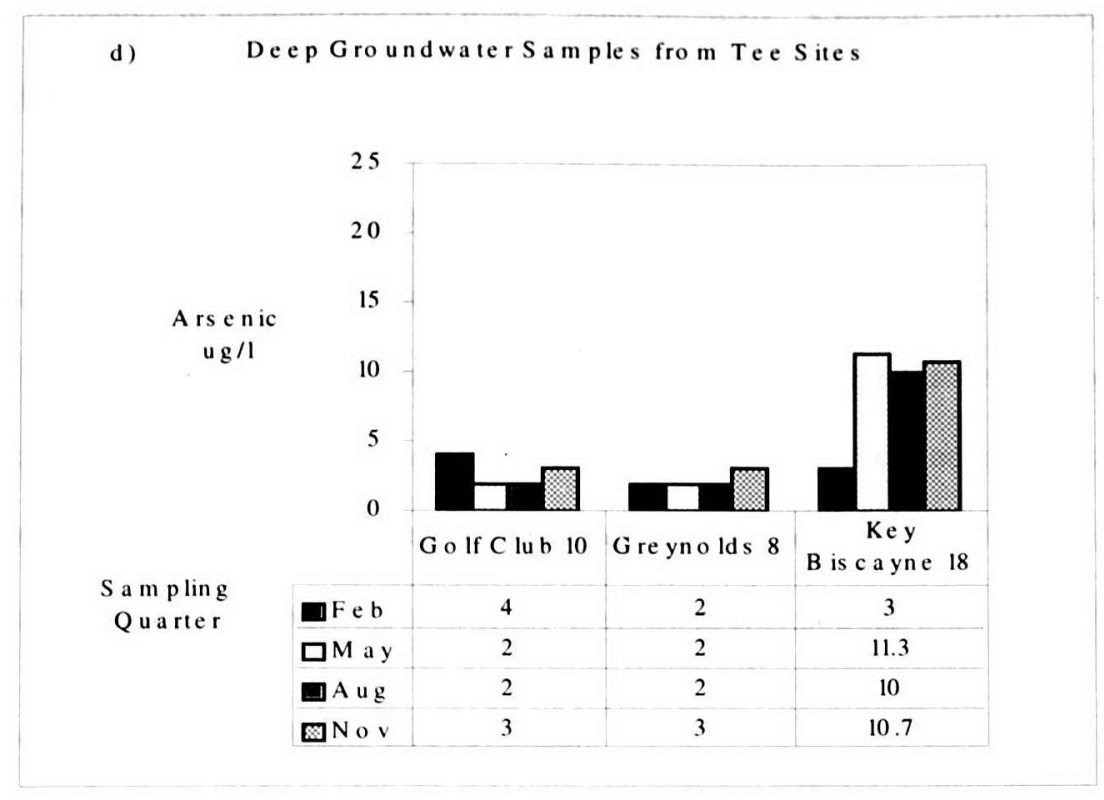

Arsenic concentration at mix/load sites and play areas

The occurrence of agrichemicals in soils and groundwater at mix load sites at golf courses is considered to be generally attributable to spills and inadequate mixing and loading practices while occurrence in the environment at play areas is assumed to be the result of legal applications. Based on the above, the loading rates of agrichemical contaminants to the environment in these two areas are expected to differ resulting in differences in contaminant levels. The data was analyzed to determine if arsenic concentration in soils and groundwater at mix/load areas was significantly different from concentrations encountered at the play areas. The data was also analyzed to determine if arsenic distribution across the play areas is consistent with 
management intensity since greens and tees are typically more intensely maintained and hence subject to more frequent agrichemical applications than fairways.

The distribution of soil arsenic concentration did not indicate a pattern based on assumed differences in loading rate and management intensity. Kruskal-Wallis analysis indicated no significant differences between the populations.

With respect to shallow groundwater, Mann-Whitney analysis indicated that the population from mix/load sites was significantly difference from tees, greens and fairways. When the data from the three play areas was compared, using the Dunn test, tee sites were found to be significantly different from greens and fairways. Greens and fairways were not significantly different. The statistical implication is that there are three separate populations with respect to groundwater arsenic concentration, mix/load sites, tees, and greens and fairways combined.

Arsenic in Surface Water and Sediments

Concentrations of arsenic in surface water samples ranged from BDL ( $2 \mathrm{ug} / \mathrm{l})$ to $34.2 \mathrm{ug} / \mathrm{l}$ with a median concentration of $19.75 \mathrm{ug} / \mathrm{l}$. There was no exceedence of the FDEP surface water CTL of $50 \mathrm{ug} / \mathrm{l}$.

The levels of arsenic in the sediment samples ranged from $0.15 \mathrm{mg} / \mathrm{kg}$ to $33.3 \mathrm{mg} / \mathrm{kg}$ with a median concentration of $2.6 \mathrm{mg} / \mathrm{kg}$. In the absence of sediment quality criteria for freshwater, the arsenic concentrations in sediments were compared to the Sediment Quality Assessment Guideline (SQAG's) developed for Florida's Coastal Waters (MacDonald 1994). Three samples exceeded the Threshold Effects Level (TEL) of $7.2 \mathrm{mg} / \mathrm{kg}$ that indicates the contaminant concentration below which adverse biological effects are not expected (MacDonald 1994). 
Figure 14: Arsenic concentration in surface water and sediment samples in ponds at four golf courses in Miami-Dade County
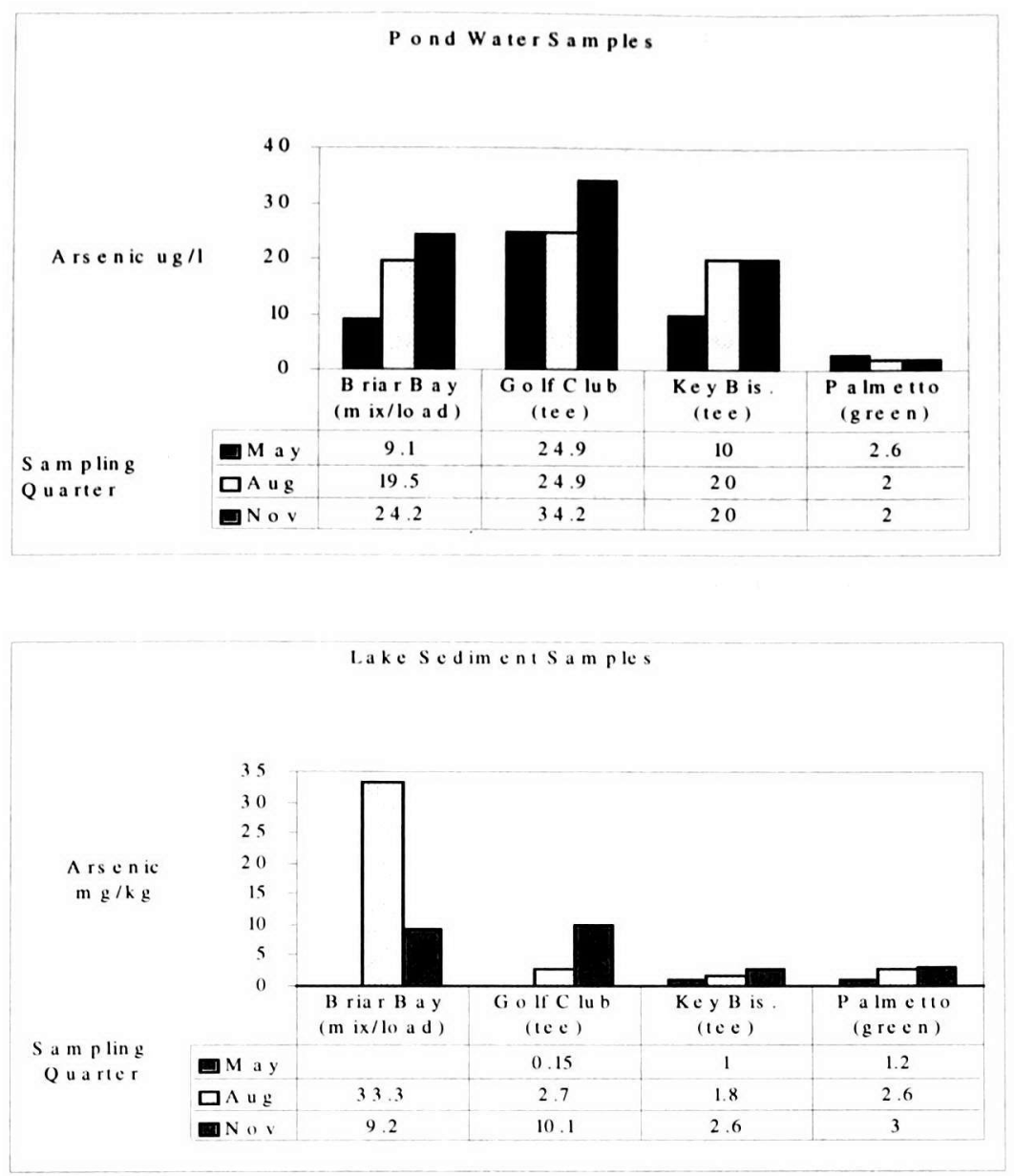

Private Home Well Sampling

In January 1998, based on the detection of arsenic in the shallow ground water at the golf courses in the study, the Florida Department of Health (FDOH), was requested to sampled private home wells within close proximity of any of the golf courses in the study. Nine home wells within a quarter mile radius of the Palmetto and Briar Bay Golf Courses were sampled for arsenic. Arsenic was detected at concentrations ranging from 0.14 to $0.59 \mathrm{ug} / \mathrm{l}$. 
Arsenic in Fertilizers

Fourteen fertilizer samples were collected from the five participating golf courses and analyzed

for arsenic as an inadvertent contaminant (Table 11).

Table 11: Arsenic concentration in fertilizer formulations

\begin{tabular}{|c|c|c|}
\hline Sampling Location & Nitrogen Source & Arsenic (mg/kg) \\
\hline \multirow[t]{4}{*}{ Golf Club of Miami } & $\begin{array}{l}\text { Ammoniated phosphate, polymer coated urea, sulfate } \\
\text { of ammonia, muriate of potash, potassium nitrate, } \\
\text { sulfate of potash. }\end{array}$ & 2 \\
\hline & $\begin{array}{l}\text { Activated sludge, polymer coated urea, ammoniated } \\
\text { phosphate, sulfate of potash, sulfate of potash- } \\
\text { magnesia, sulfur coated urea }\end{array}$ & 1 \\
\hline & $\begin{array}{l}\text { Sulfate of potash, copper oxide, iron oxide, manganese } \\
\text { sulfate, manganese oxide, zinc oxide, sodium borate, } \\
\text { iron sulfate }\end{array}$ & 4.3 \\
\hline & $\begin{array}{l}\text { Ammoniated phosphate, polymer coated urea, } \\
\text { potassium nitrate, sulfate of ammonia, sulfate of } \\
\text { potash, muriate of potash. }\end{array}$ & 2 \\
\hline \multirow[t]{3}{*}{$\begin{array}{l}\text { Greynolds Park } \\
\text { Golf Course }\end{array}$} & $\begin{array}{l}\text { Sulfate of ammonia, di-ammonium phosphate, sulfate } \\
\text { of potash, sulfate of potash-magnesia, sulfur coated } \\
\text { urea, manganese oxide, iron oxide. }\end{array}$ & 6.9 \\
\hline & $\begin{array}{l}\text { Sewage sludge, packaged for retail use as a soil } \\
\text { amendment }\end{array}$ & 6.8 \\
\hline & $\begin{array}{l}\text { Sulfate of ammonia, activated sludge, sulfate of } \\
\text { potash, magnesium sulfate }\end{array}$ & 2.7 \\
\hline \multirow[t]{4}{*}{$\begin{array}{l}\text { Palmetto \& Briar } \\
\text { Bay Golf Courses }\end{array}$} & $\begin{array}{l}\text { Sewage sludge, sulfur coated urea, triple super } \\
\text { phosphate, sulfate of potash, sulfate of potash- } \\
\text { magnesia. }\end{array}$ & 2 \\
\hline & Sulfate of ammonia & 0.8 \\
\hline & $\begin{array}{l}\text { Poly coated urea, coated urea, monoammonium } \\
\text { phosphate, sulfate of potash, iron oxide, iron sulfate, } \\
\text { manganese oxide, manganese oxide. }\end{array}$ & 2 \\
\hline & Sulfur coated urea & BDL \\
\hline \multirow[t]{3}{*}{$\begin{array}{l}\text { Key Biscayne Golf } \\
\text { Club }\end{array}$} & $\begin{array}{l}\text { Poly coated sulfur coated urea, monoammonium } \\
\text { phosphate, sulfate of potash, iron oxide, iron sulfate } \\
\text { oxide, manganese sulfate. }\end{array}$ & 15 \\
\hline & Sulfur coated urea & BDL \\
\hline & Sulfate of ammonia & BDL \\
\hline
\end{tabular}


Arsenic Speciation

\section{Groundwater}

Speciation analysis of five groundwater arsenic samples indicated that arsenic was present as inorganic arsenic, with the (As ${ }^{5+}$ ) species the predominant ion. The organic species (MMAA), present in the herbicide (MSMA) typically used at golf courses, was not detected. Trace amounts of arsenite $\left(\mathrm{As}^{3+}\right)$ was detected in one sample (Figure 15). The absence of arsenites and MMAA is consistent with the fact that in well oxidized environments, $\mathrm{As}^{5+}$ is the equilibrium species.

Figure 15: Arsenic species distribution in groundwater

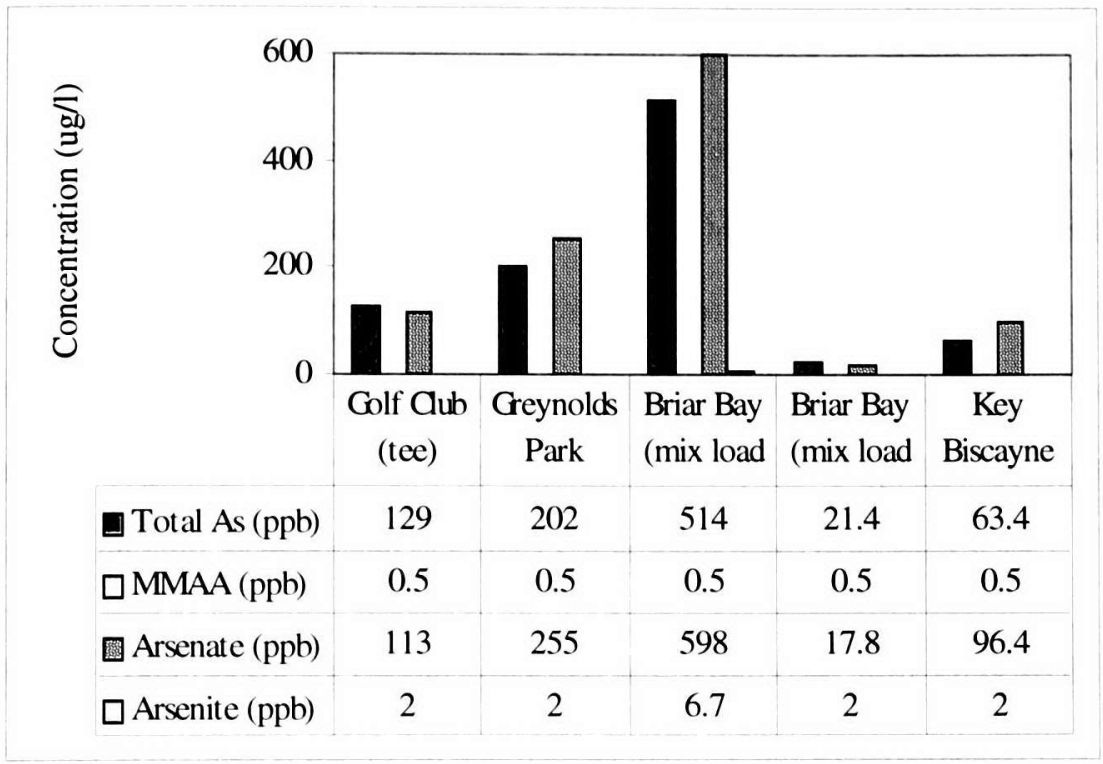

Soils

Six soil samples, also obtained during August 1997 were also submitted for arsenic speciation analysis. All the recovered arsenic was in the form of inorganic arsenates. The absence of the arsenite species is inconclusive, since one limitation of the analytical methodology is the possibility that any arsenite present could be oxidized to arsenate during the extraction process. 


\section{Pesticides}

\section{Ground water}

Concentrations of pesticides in groundwater were generally low and were undetected in over $95 \%$ of the samples. Pesticides were detected above practical quantitation limit (PQL) in ten samples from shallow monitoring wells and in one sample from a background well in a residential neighborhood. A total of six pesticide residues were detected (Table 12).

Chlorothalonil was detected once at the mix/load site at Briar Bay Golf Course. Chlorothalonil is a contact fungicide for the control of a board spectrum of fungi. A 1996 pesticide use survey (mail out survey administered by author) indicated that between 2.5 and 25 gals (active ingredient) per year are used at golf courses in Miami-Dade County. A total of four different pesticide residues were detected in groundwater at Golf Club of Miami. Metribuzin, one of the most preferred herbicide used at golf courses in Miami-Dade County, was detected three times. Metribuzin is used alone or more typically in combination with MSMA for the control of goosegrass (personal communication). Oxadiazon, is a pre-emergent herbicide used in crabgrass and goosegrass control was detected once. This product is applied twice per year at the Golf Club of Miami with an estimated 0.5 tons (active ingredient) used each year.

The two other pesticide residues detected in ground water were chlorpyrifos-methyl and dieldrin. Neither is registered for use in turf management. Chlorpyrifos-methyl is registered as an insecticide for use on stored grain. Dieldrin is no longer registered for use in the United States. All registered uses were cancelled in 1987. However, dieldrin is very persistent in the environment ( $\mathrm{T}_{1 / 2}>1000$ days) and as such its presence at the Golf Club of Miami may be a remnant of historical usage. Dieldrin was the only pesticide detected at concentrations above the Florida ground water CTL. 
Table 12: Pesticides detected in ground water

\begin{tabular}{|l|l|l|l|l|l|l|}
\hline $\begin{array}{l}\text { Station } \\
\text { ID }\end{array}$ & Well & $\begin{array}{l}\text { Sampling } \\
\text { Quarter }\end{array}$ & $\begin{array}{l}\text { Conc } \\
(\mathrm{ug} / \mathrm{l})\end{array}$ & $\begin{array}{l}\text { Pesticide } \\
\text { Residue }\end{array}$ & Criteria *(ug/l) & $\begin{array}{l}\text { Criteria } \\
\text { Exceeded? }\end{array}$ \\
\hline BBML & Shallow 4 th & 0.25 & Chlorothalonil & 3.18 & No \\
\hline GCML & Shallow & 2nd & 1.6 & Metribuzin & 175 & No \\
\hline GCML & Shallow & 4th & 0.95 & $\begin{array}{l}\text { Chlorpyrifos } \\
\text { Methyl }\end{array}$ & 70 & No \\
\hline GCG13 & Shallow & 4 th & 9.7 & Metribuzin & 175 & No \\
\hline GCT10 & Shallow & 1st & 0.14 & Oxadiazon & 35 & No \\
\hline GCT10 & Shallow & 1st & 0.49 & Dieldrin & 0.1 & Yes \\
\hline GCT10 & Shallow & 2nd & 0.12 & Dieldrin & 0.1 & Yes \\
\hline GCT10 & Shallow & 4th & 0.056 & Dieldrin & 0.1 & No \\
\hline GCT10 & Shallow & 4th & 1.3 & Metribuzin & 175 & No \\
\hline GW 50 & $\begin{array}{l}\text { Back } \\
\text { ground }\end{array}$ & & 0.48 & Atrazine & 3 & No \\
\hline
\end{tabular}

* FDEP: MCL, CTL or Guidance Concentration (Chapter 62-777, Florida Administrative Code)

Atrazine was detected in one of the ambient background well, GW50, located in a residential area approximately one mile to the SE of Golf Club of Miami. Atrazine is registered for use on residential lawns and is the most commonly detected pesticide in shallow groundwater in urban areas nationally (Barbash et al., 1999). Pesticides were detected most frequently at the Golf Club of Miami. Eighty-one percent of the pesticides detected in groundwater during the study were detected at the Golf Club of Miami. This can be partially explained by the fact that this was the 
only golf course consistently sampled for chlorinated pesticides. Four of the ten pesticide detections in ground water $(40 \%)$ at the study courses was dieldrin, a chlorinated pesticide.

\section{Surface Water}

Trace amounts of four pesticide residues, fonofos, atrazine, oxadiazon, and ethoprop were detected in surface water from golf course ponds (Table 13). Fonofos (1.2 ug/l) and ethoprop $(0.66 \mathrm{ug} / \mathrm{l})$ exceeded the surface water cleanup target level (62-777 Florida Administrative Code).

Table 13: Pesticides Detected in the Surface Water

\begin{tabular}{|l|l|l|l|l|l|}
\hline $\begin{array}{l}\text { Near } \\
\text { GW site }\end{array}$ & $\begin{array}{l}\text { Station } \\
\text { ID }\end{array}$ & $\begin{array}{l}\text { Sampling } \\
\text { Quarter }\end{array}$ & $\begin{array}{l}\text { Concentration } \\
\mathrm{ug} / \mathrm{l}\end{array}$ & $\begin{array}{l}\text { Pesticide } \\
\text { Residue }\end{array}$ & $\begin{array}{l}\text { Surface water } \\
\text { cleanup target } \\
\text { level (ug/l) }\end{array}$ \\
\hline Mix/load & BBL & Third & 1.2 & Fonofos & 0.095 \\
\hline Tee 10 & GCL & Second & 1.5 & Atrazine & 1.8 \\
\hline Tee 10 & GCL & Third & 1.8 & Oxadiazon & 44 \\
\hline Tee 10 & GCL & Fourth & 2.3 & Oxadiazon & 44 \\
\hline Tee 10 & GCL & Fourth & 0.47 & Atrazine & 1.8 \\
\hline Green 7 & PML & Third & 0.66 & Ethoprop & 0.315 \\
\hline
\end{tabular}

Sixty seven percent of pesticide detections in surface water occurred at the Golf Club of Miami. Atrazine and oxadiazon were detected twice. The Golf Club of Miami uses approximately 4-6 tons (mixed product weight) of an atrazine/fertilizer mix per year and approximately 25 tons (mixed product weight) of oxadiazon. Oxadiazon was the only pesticide detected in both ground and surface water at golf courses both detections occurred at the Golf Club of Miami.

Fonofos and ethoprop were detected at the Briar Bay and Palmetto Golf Courses, respectively. Pesticide inventory records from these golf courses (personal communication) indicate that 
fonofos was last used at the Briar Bay Golf Course in 1996 and there is no record of ethoprop use at the Palmetto Golf Course in the two years prior to the study.

\section{Nutrient Components}

Nitrates in ground water

Eleven shallow groundwater samples exceeded the MCL for nitrates. All of these exceedences were from mix/load sites and occurred at least once at each golf course. Overall highest nitrate concentration in shallow groundwater was encountered at the mix/load site at Greynolds Park Golf Course (Figure 10). Median nitrate concentration in shallow wells calculated as $1.15 \mathrm{mg} / \mathrm{l}$ was above an ambient background of $0.02 \mathrm{mg} / \mathrm{l}$ obtained from the AWQM network $(\mathrm{n}=235)$. None of the deep well samples exceeded the MCL. Summary statistics for nitrates in groundwater are presented in Table 14.

The presence of high levels of nitrates in shallow ground water at mix/load sites may be due in part to the fact that except for the Palmetto Golf Course, the mix/load area is also used for washing equipment including fertilizer spreaders and as such fertilizer residues remaining in the spreader after application is washed off and can potentially leach into the underlying groundwater.

Statistical multiple comparison analysis (Dunn test) of nitrates in shallow groundwater from the different golf course areas indicated that a significant difference exist between mix/load sites and greens and fairways but there was no significant difference between mix/load and tee site. With respect to play areas, tee sites were different from greens and fairways. This is consistent with fertilization requirements, tees typically require more fertilizer than greens then fairways (Balough and Walker, 1992). 
Phosphates in ground water

Concentrations of total phosphates $\left(\mathrm{TPO}_{4}\right)$ in groundwater ranged from BDL $(0.02 \mathrm{mg} / \mathrm{l})$ to 1.069 $\mathrm{mg} / \mathrm{l}$. The median phosphate concentration for shallow wells was $0.16 \mathrm{mg} / \mathrm{l}$ as compared to 0.06 $\mathrm{mg} / \mathrm{l}$ in the deep wells. Phosphate levels in ground water at the study sites were elevated over median background concentrations. Historical data from the AWQMN $(n=458)$ indicate background concentrations of phosphate in groundwater at $0.029 \mathrm{mg} / \mathrm{l}$.

Table 14: Summary statistics for nitrates in groundwater (all concentrations in $\mathrm{mg} / \mathrm{l}$ )

\begin{tabular}{|l|l|l|l|l|l|l|l|l|}
\hline $\begin{array}{l}\text { Type } \\
\text { of Site }\end{array}$ & $\begin{array}{l}\text { Well } \\
\#^{*}\end{array}$ & $\mathrm{n}$ & Min & Max & Median & $\begin{array}{l}25^{\text {th }} \\
\text { percentile }\end{array}$ & $\begin{array}{l}75^{\text {th }} \\
\text { percentile }\end{array}$ & $\begin{array}{l}\text { \# samples } \\
\text { above MCL }\end{array}$ \\
\hline Fairway & 1 & 15 & 0.01 & 8.28 & 0.26 & 0.02 & 0.49 & None \\
\hline & 2 & 15 & 0.01 & 0.05 & 0.01 & 0.01 & 0.02 & None \\
\hline Green & 1 & 10 & 0.01 & 6.77 & 0.02 & 0.01 & 2.39 & None \\
\hline & 2 & 11 & 0.01 & 8.34 & 0.06 & 0.02 & 2.04 & None \\
\hline Tee & 1 & 10 & 0.10 & 9.24 & 1.70 & 0.49 & 8.01 & None \\
\hline Mix/Load & 1 & 17 & 0.01 & 49.5 & 11.30 & 4.80 & 24.60 & 11 \\
\hline & 2 & 16 & 0.01 & 6.38 & 0.03 & 0.01 & 0.34 & None \\
\hline All Sites & 1 & 52 & 0.01 & 49.5 & 1.15 & 0.03 & 8.27 & 11 \\
\hline & 2 & 52 & 0.01 & 8.34 & 0.03 & 0.01 & 1.28 & None \\
\hline
\end{tabular}


Figure 16: Nitrate concentration in groundwater at golf courses in Miami-Dade County
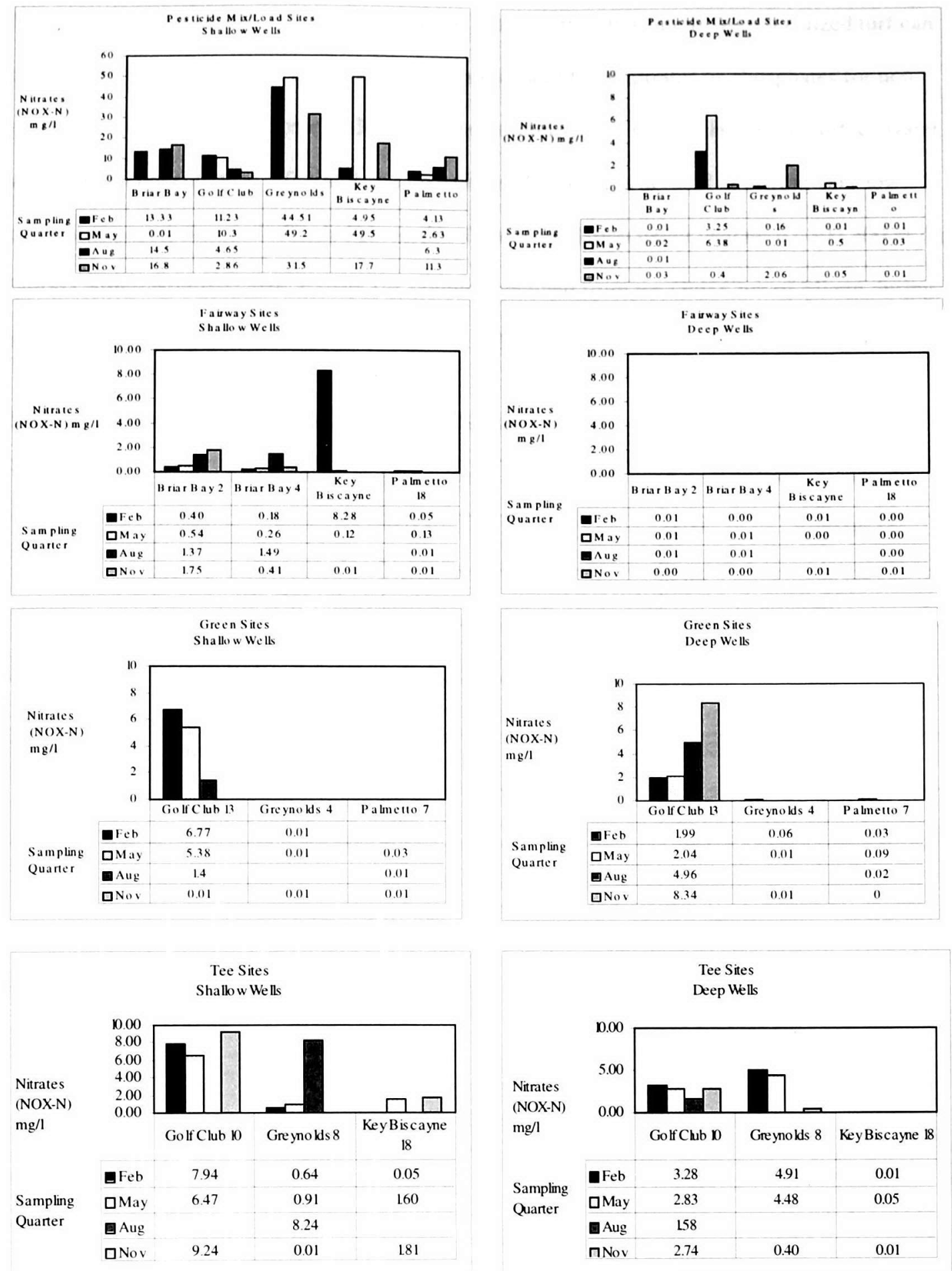
Nitrates and Phosphates in Ponds

Nutrients are a concern to the ecology of ponds since stormwater runoff from fertilized turf can cause eutrophication. There are no surface water standards for nitrates or phosphates for nonpotable surface waters (Chapter 62-302, Florida Administrative Code). However, surface water with nitrate concentration $<0.3 \mathrm{mg} / \mathrm{l}$ and phosphate $<0.04 \mathrm{mg} / \mathrm{l}$ is defined as having very low nutrient concentration and afforded protection from degredation under chapter 62-302.300 of the Florida Administrative Code. Except for samples obtained from the Golf Club of Miami during the fourth sampling quarter, surface water from golf course ponds is low in nutrients (Table 15).

Table 15: Nutrient Levels in Golf Course Ponds (data as mg/l)

\begin{tabular}{|l|l|l|l|l|l|}
\hline & Sampling Quarter & Briar Bay & Golf Club & Key Biscayne & Palmetto \\
\hline \multirow{4}{*}{ Nitrates } & Second & 0.07 & 0.17 & 0.07 & 0.06 \\
\cline { 2 - 6 } & Third & $<0.01$ & 0.08 & 0.02 & 0.08 \\
\cline { 2 - 6 } & Fourth & 0.03 & 0.52 & 0.03 & $<0.01$ \\
\hline \multirow{3}{*}{ Phosphates } & Second & 0.05 & 0.19 & 0.03 & 0.03 \\
\cline { 2 - 7 } & Third & 0.06 & 0.09 & $<0.02$ & $<0.02$ \\
\cline { 2 - 7 } & Fourth & 0.08 & 0.23 & $<0.02$ & $<0.02$ \\
\hline
\end{tabular}




\section{DISCUSSION}

\section{Summary}

\section{Arsenic}

Golf course soils are impacted by arsenic agrichemicals used in routine turf management activities. Soil samples collected during the study were elevated above natural background concentrations for arsenic. Seventy-five percent of all soil samples exceeded the residential soil cleanup target level for arsenic and 62 percent exceeded the industrial soil cleanup target level. Highest arsenic concentrations were found in surficial and subsurface soils and decreased with depth. The study documented exceedences of the residential and industrial soil cleanup target levels down to the soil/water interface. The implication is that environmental conditions encountered at the study sites are conducive to vertical migration of arsenic through the soil column.

Shallow ground water at the study golf courses is contaminated with arsenic. Highest arsenic concentrations in shallow groundwater were found at mix/load sites while tee sites had the highest percentage of exceedences of the groundwater MCL for arsenic. Based on arsenic concentration in shallow groundwater, golf courses represent three statistically different populations, mix/load sites, tees and greens/fairways. While arsenic contamination at greens fairways and tees is assumed to be the result of routine pesticide application, contamination at mix/load sites is in part attributable to spills and discharges that result from inadequate mix/loading practices.

Although arsenic appears to leach into shallower groundwater at the soil/groundwater interface there is very limited vertical migration through the water column. Deep ground water is relatively 
unimpacted by arsenic with concentrations being very similar to background arsenic concentration from the AWQM.

Thirty two percent of samples from shallow wells exceeded the current groundwater MCL of 50 ug/l, 76.6 percent would exceed a lowered MCL of $10 \mathrm{ug} / \mathrm{l}$. While there are no exceedences of the current MCL from the deep wells, 18 percent of the samples would exceed the MCL if lowered to 10ug/l.

Although the levels of arsenic in surface water from golf course ponds did not exceed the surface water standard, the concentrations encountered were typically at least an order of magnitude higher than levels found at surface water monitoring sites around Miami-Dade County. Although the sample size was very small and therefore limits the ability to draw conclusions, the implication is that golf course ponds appear to be impacted by runoff and /or drift from the application of arsenical agrichemicals used in routine turf management. There were not enough sediment samples to determine if sediments in golf course ponds were the 'sink' for arsenic.

The data from this study indicate that soil, shallow groundwater and to a lesser extent surface water from the study golf courses are impacted by arsenic. Arsenical agrichemicals used in routine turf management activities are implicated.

\section{Pesticides}

Generally, pesticides were detected in shallow groundwater and surface water in trace amounts. In some cases the source of these pesticides cannot be linked to golf course turf management activities. 


\section{Nutrients}

As with arsenic the most significant impact with respect to nitrates in groundwater appears to result from mix/loading and associated activities. However, ground water under the play areas on the courses also shows nitrate concentrations that are elevated above background. The distribution of nitrates in ground water from the play areas appears to be consistent with routine turf management practices. Arsenic concentration in groundwater decreases from tees to greens to fairways. This coincides with relative fertilization rates.

\section{Recommendations}

Based on the data, the following recommendations are offered:

1. The study documents, the impact of arsenic to soils and groundwater at the golf courses studied. Further assessment is required to determine the aerial extent of the contamination especially with respect to the potential for offsite migration.

2. Arsenical pesticides and to a lesser extent fertilizer/soil amendments have been identified as potential contributors to arsenic contamination in the golf course environment. Specific best management practices are needed to minimize the impact of arsenic to the environment.

3. The data indicates that the current agrichemicals mixing and handling practices significantly contribute to soil and groundwater contamination. As indicated by the data from Palmetto Golf course, improved mix/loading and storage facilities can minimize the impacts associated with agricultural mix/loading and handling activities.

4. In order to fully characterize the sources of arsenic in the golf course environment, other potential sources such as fill material should be investigated. 
5. Based on the distance of the potable wells from the golf courses, an effort should be made to locate and sample potable or irrigation wells closer to the golf courses in order to assess off site migration.

6. Data from the study should be compared with available data from other parts of the state to determine the actual magnitude of the problem and to identify potentially vulnerable areas. 


\section{LIST OF REFERENCES}

Balogh. J. C. and W. J. Walker. 1992. Golf Course Management and Construction: Environmental Issues. Lewis Publishers, MI. pp 1-37.

Barash. J.E., G.P. Thelon, D.W. Kolpin, and R.J. Gilliom. 1999. Distribution of Major Herbicides in Groundwater of the United States. US Geological Survey Water Resources Investigation Report 98-4245.

Cohen. S. Z., S. Nickerson, R. Maxey, A. Dupuy Jr., and J. A. Senita. 1990. A Groundwater Monitoring Study for Pesticides and Nitrates Associated with Golf Courses on Cape Cod. Ground Water Monitoring Review. Winter 1990, pp 160-173

Chapter 17-520, Florida Administrative Code.

Chapter 17-520.420(1), Florida Administrative Code. Minimum Criteria for Groundwater Quality

Chapter 62-302, Florida Administrative Code.

Chapter 62-302.530, Florida Administrative Code. Surface Water Quality Classification.

Chapter 62-777, Florida Administrative Code.

Chapter 62-777, Florida Administrative Code. Contaminant Cleanup Target Levels

DERM Agricultural Waste Permitting Files.

Department of Environmental Resources Management Agricultural Waste Permitting Files, Golf Course Maintenance Facility inspection reports 1996-1998.

Fish. J. E., and M. Stewart. 1991. Hydrogeology of the Surficial Aquifer System, Miami-Dade County, Florida. U.S. Geological Survey Water Resources Investigation Report 90-4108

Gibbons. R.D. 1994. Statistical Methods for Groundwater Analysis, John Wiley and Sons, Inc, pp 188-189

MacDonald, D.D. 1994. Approach to the Assessment of Sediment Quality in Florida Coastal Waters. Prepared for Florida Department of Environmental Protection, Office of Water Policy by MacDonald Environmental Sciences Ltd.

Miami-Dade Public Works Department. 1955. Topography Maps of Dade County

Miles, C. J., G. Leong, and S. Dollar. 1992. Pesticides in Marine Sediments Associated with Golf Course Runoff. Bulletin of Environmental Contamination and Toxicology. (1992) 49: 179-185.

National Golf Foundation. 1991. Golf Facilities in the United States. National Golf Foundation, Jupiter, Florida (cited in Balogh and Walker 1992) 
Noble, C. V., R. W. Drew and J. D. Slabaug. 1996. Soil Survey of Miami-Dade County Area, Florida. USDA, Natural Resources Conservation Service.

Parker, G. G., G. E. Ferguson and S. K. Love. 1955. Water Resources of Southeastern Florida. United States Department of Interior, Geological Survey Water Supply Paper 1255.

Radall, M. J., and B. G. Katz. 1991. Major Ions and Selected Trace Metals Chemistry of the Biscayne Aquifer, Southeast Florida. U.S. Geological Survey Water Resources Investigation Report 91-4009.

Randell, M.J., and B.G. Katz. 1991. Major Ions and Selected Trace Metals Chemistry of the Biscayne Aquifer, Southeast Florida. U.S. Geological Survey Water Resources Investigation Report 91-4009.

Swancar, A. 1996. Water Quality, Pesticide Occurrence and Effects of Irrigation with Reclaimed Water at Golf Courses in Florida. U.S. Geological Survey Water Rescurces Investigation Report $95-4250$.

Song H. and A.E. Smith. 1996. Potential Movement of Dithiopyr following Application to Golf Courses. Journal of Environmental Quality. Vol26, March-April 1997 pp 379-386.

Starrett, S.K., N.E. Christians and T.A. Austin. 1994. Movement of Pesticides under Two Irrigation Regimes Applied to Turfgrass. Journal of Environmental Quality, Vol., 25, May-June 1996 pp., 566-571.

USGS. United States Geological Survey. Pesticides in Groundwater: Current Understanding of Distribution and Major Influences. USGS Fact Sheet FS-244-95

USGA. United States Golf Association Green Section Record. Vol., 33, No.1, January/February 1995

Wan, H.H., M.K. Wong and C.Y. Mok. 1994. Pesticides in Golf Course Waters Associated with Golf Course Runoff. Bulletin of Environmental Contamination and Toxicology. (1996) 56: 205209.

Zar, J.H. Biostatistical Analysis. Department of Biological Sciences, Northern Illinois University. Prentice Hall $3^{\text {rd }}$ edition. 1996 
APPENDICES 
总

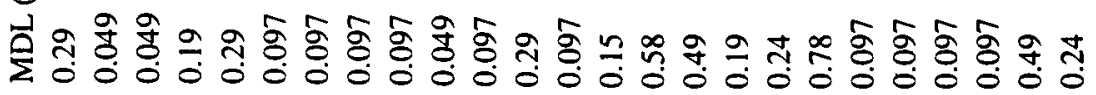

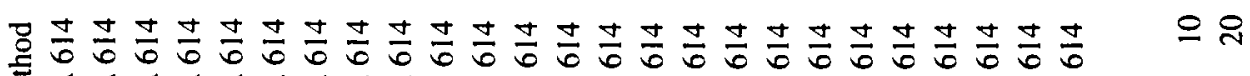

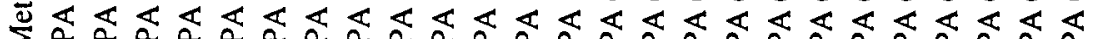

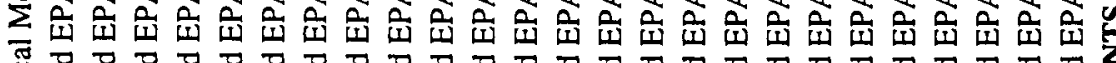

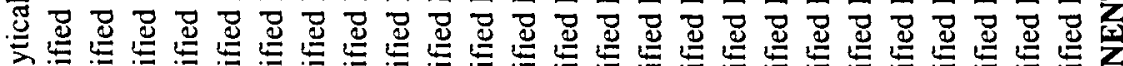

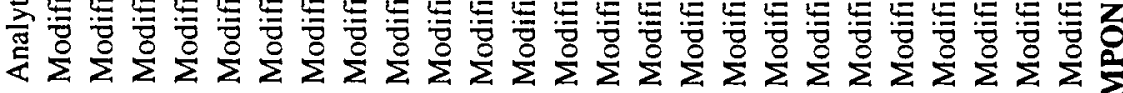

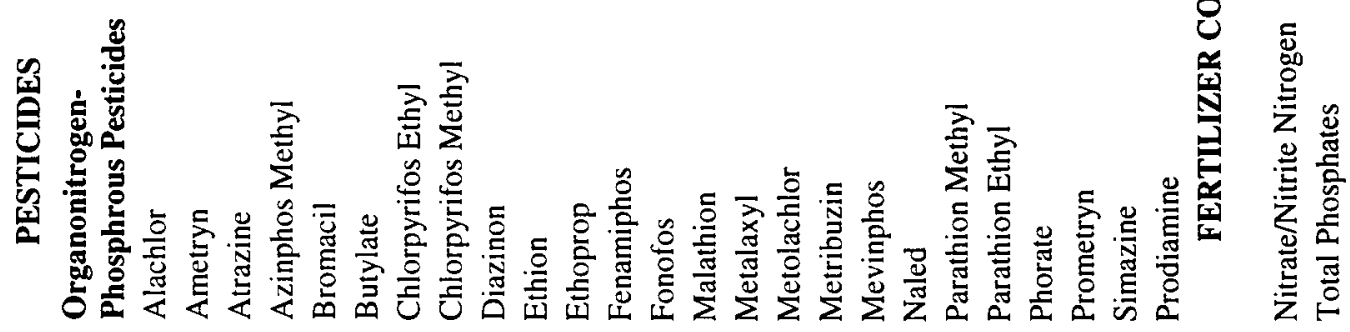

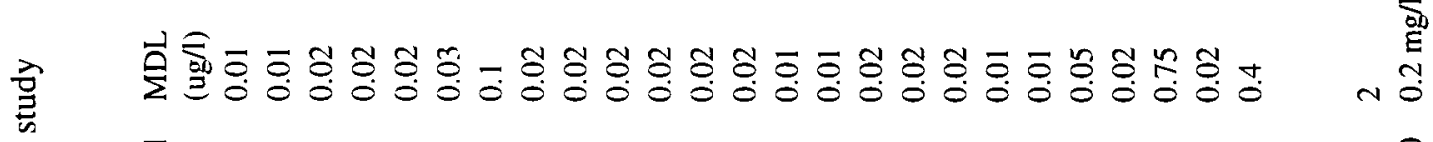

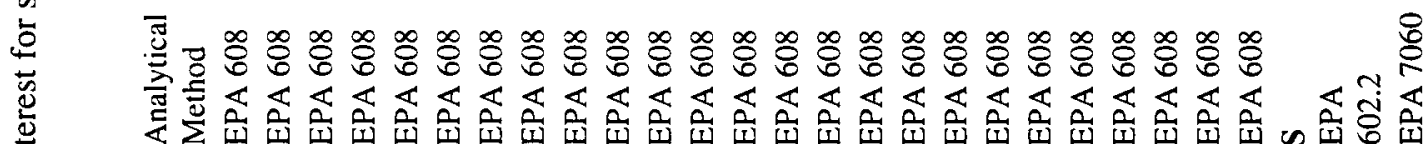

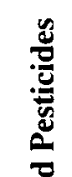

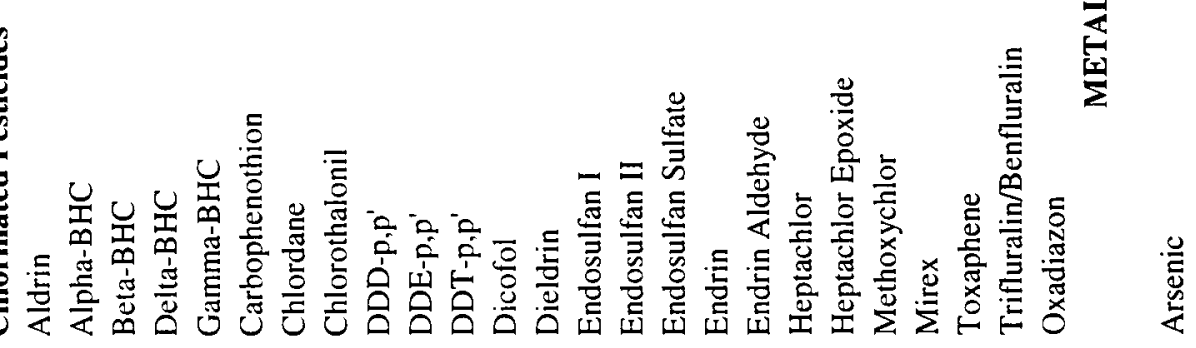




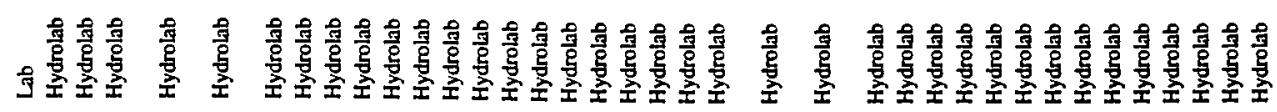

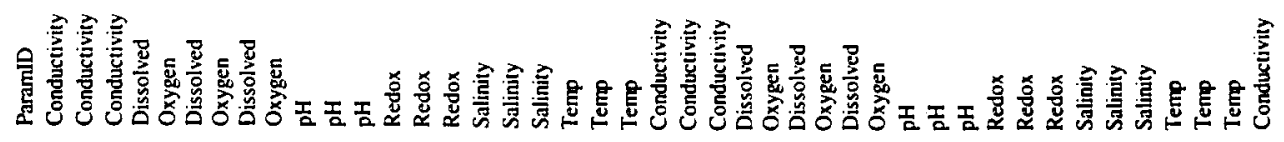

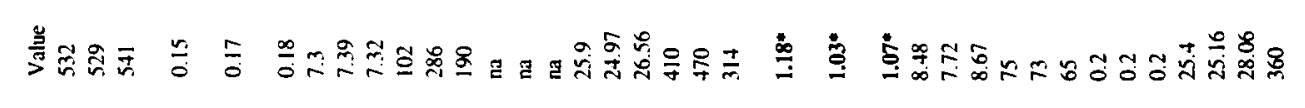

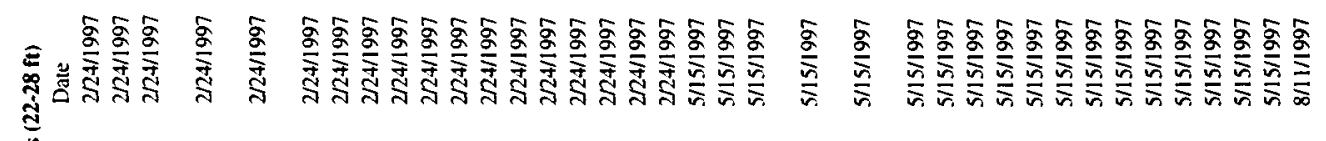

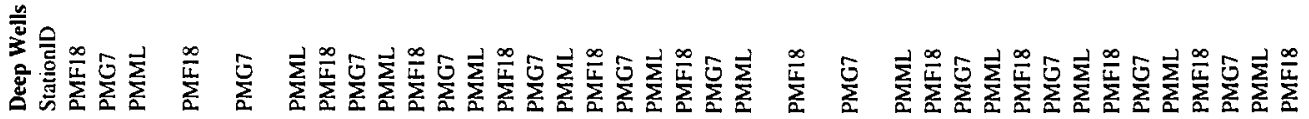

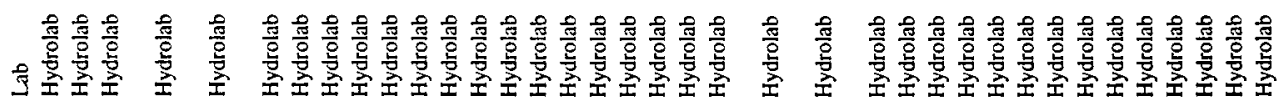

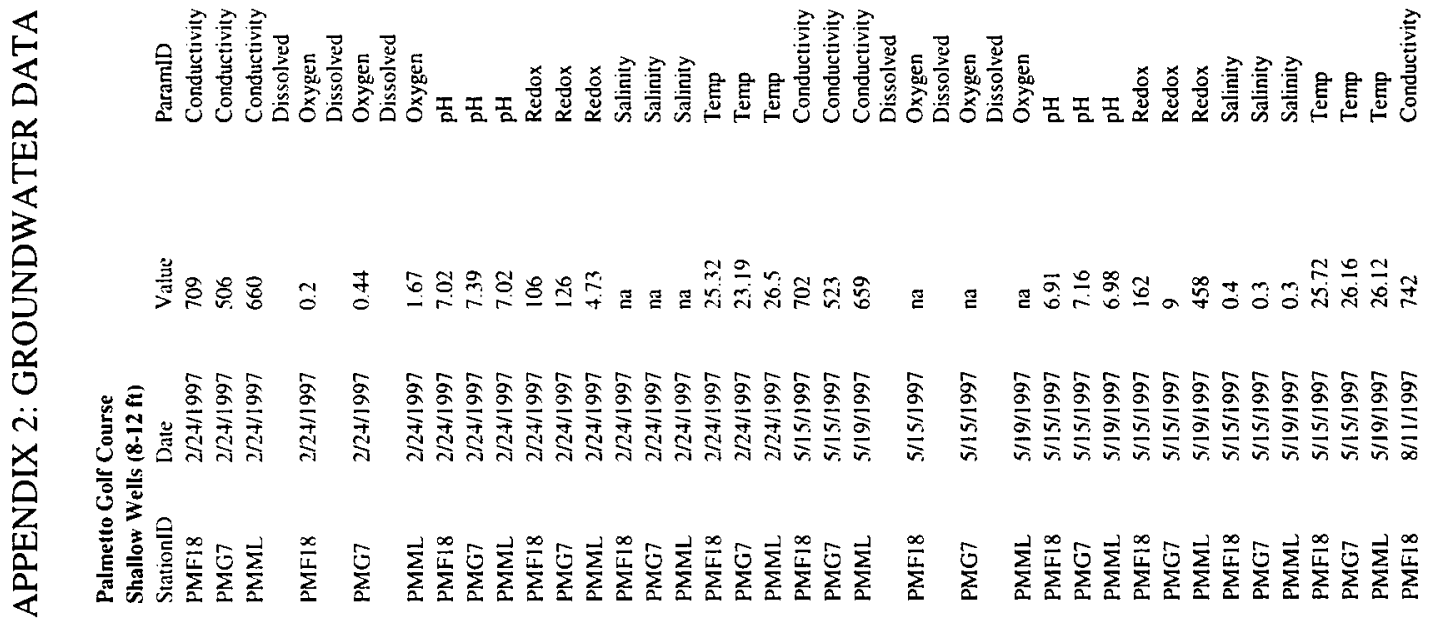




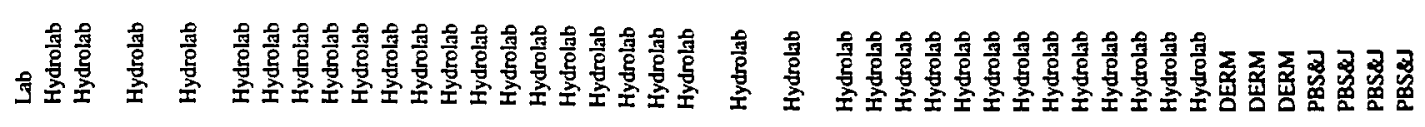

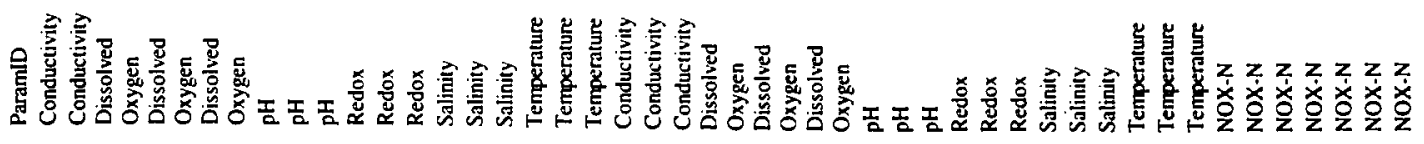

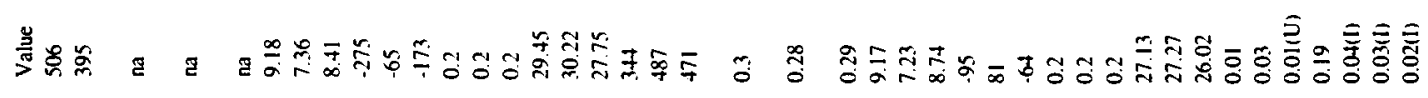

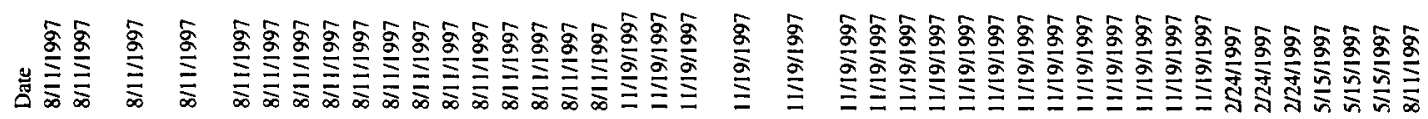

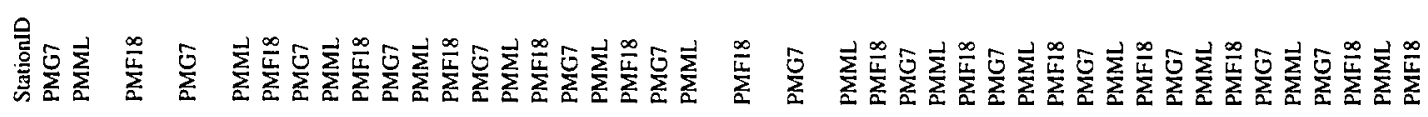

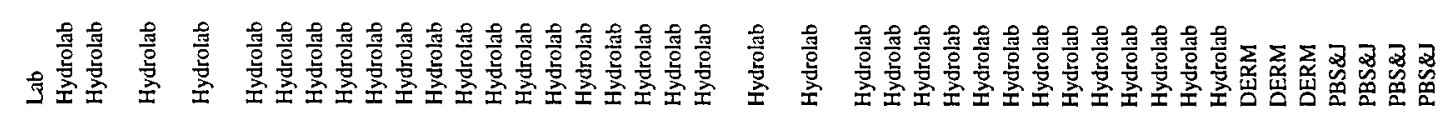

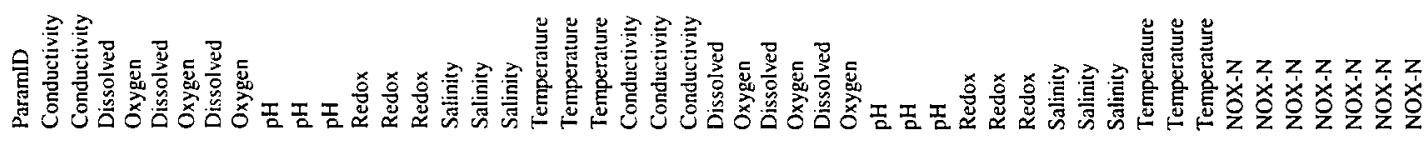

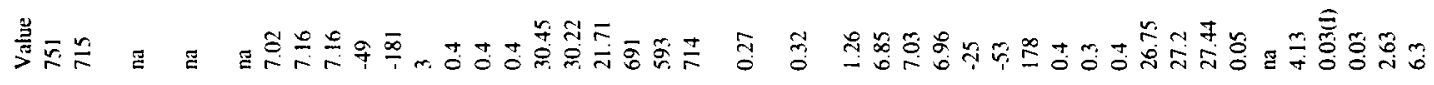

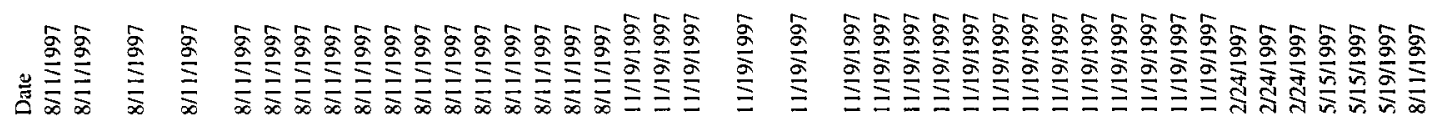

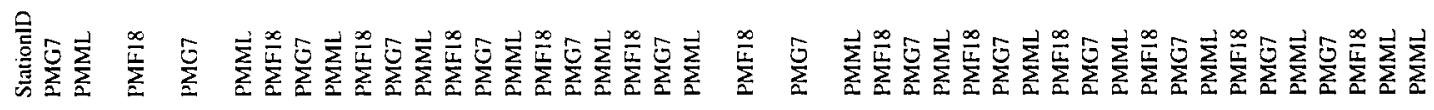




\section{ง}

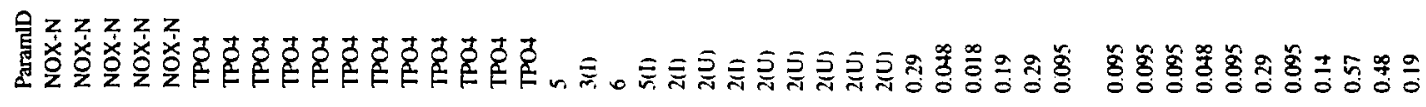

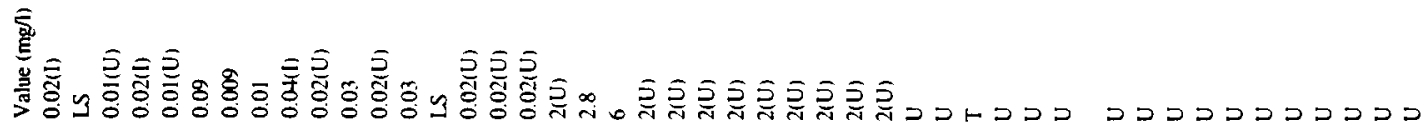

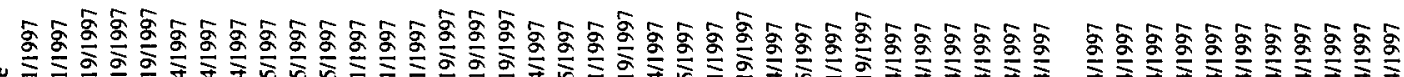

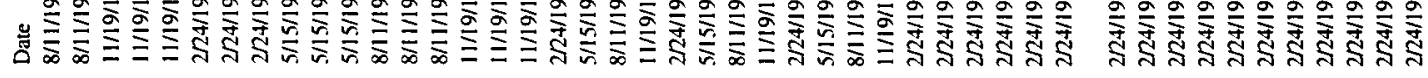

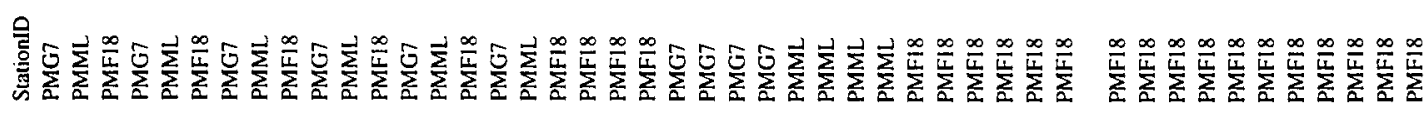

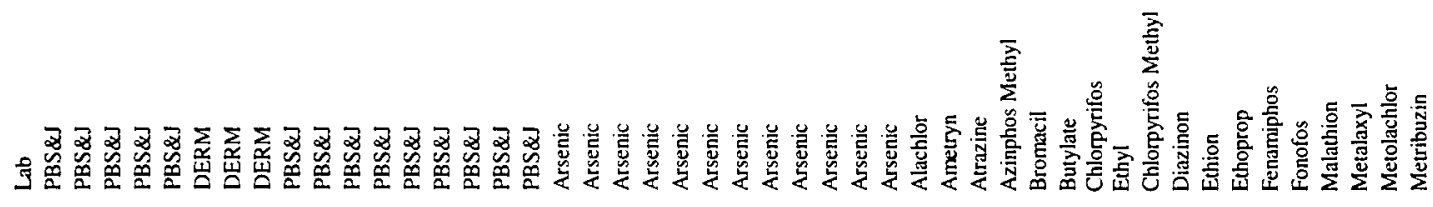

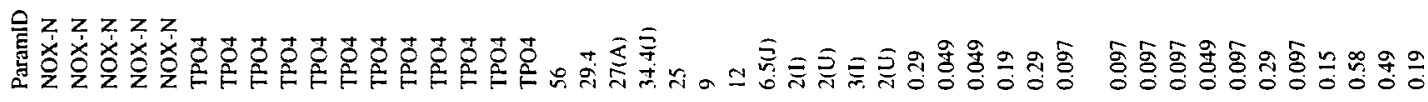

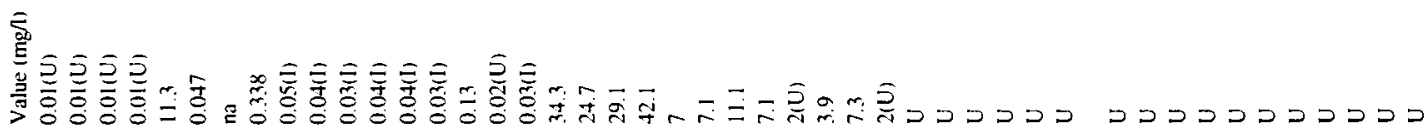

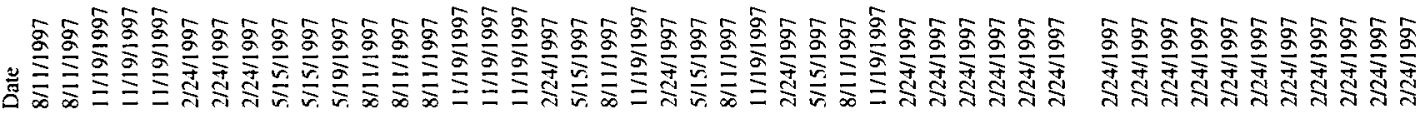

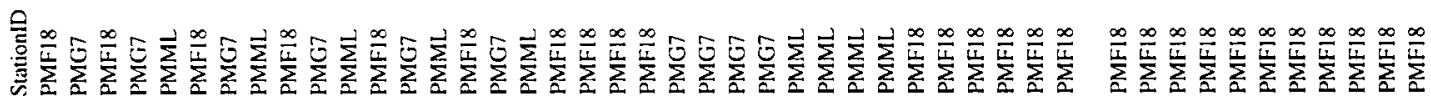




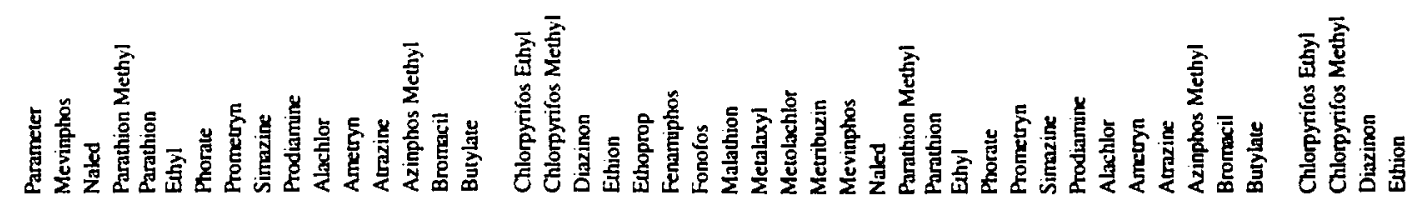

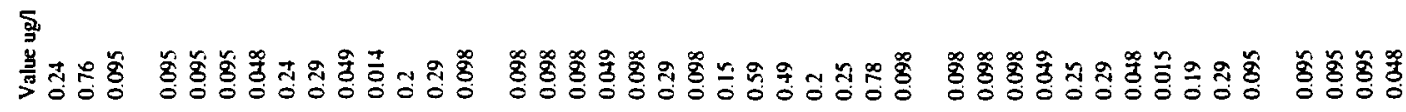

tos

|

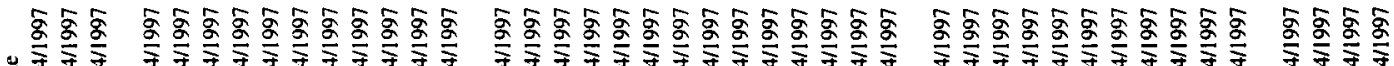

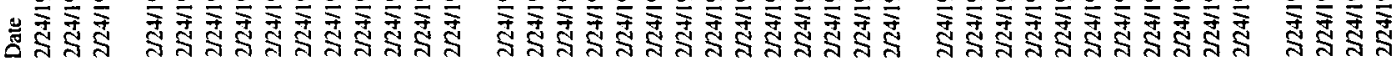

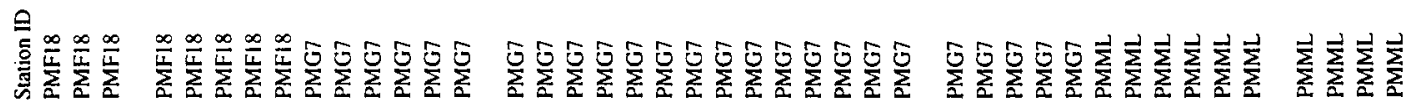

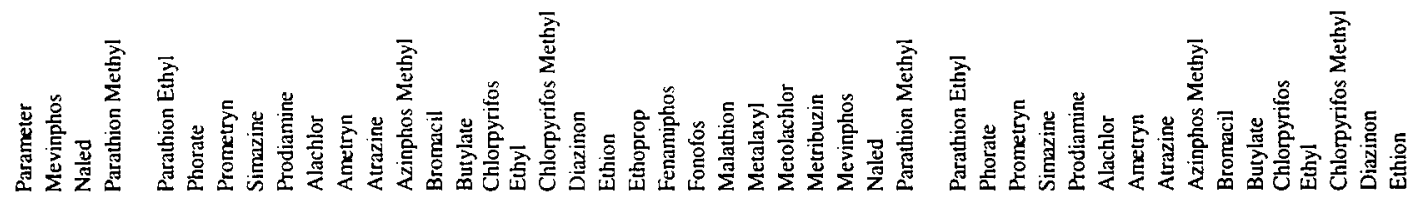

ธิ

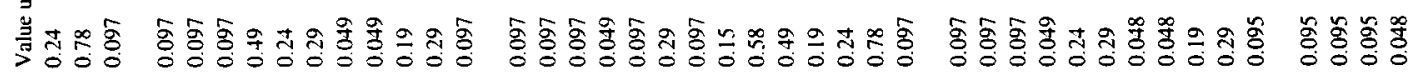

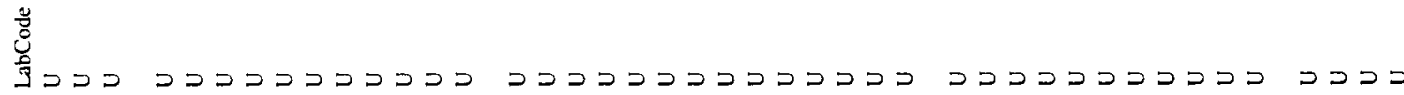

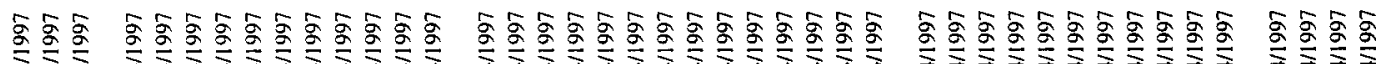

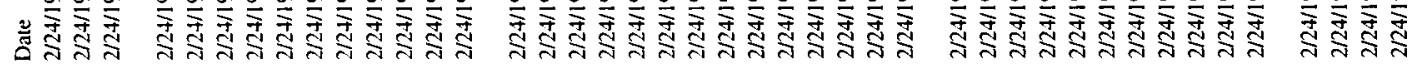

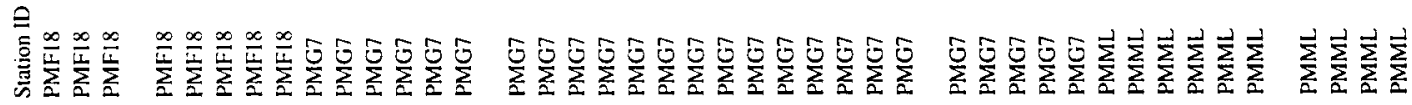




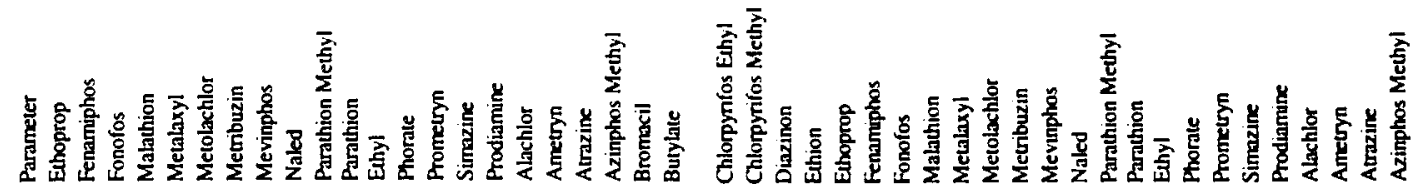

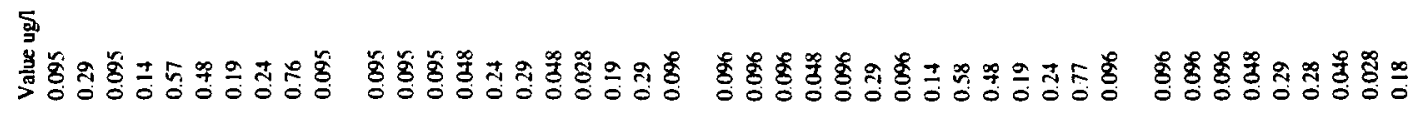

8.

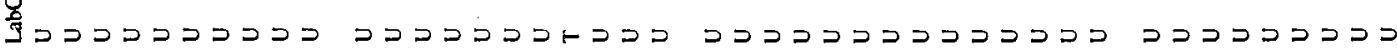

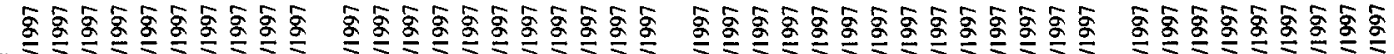

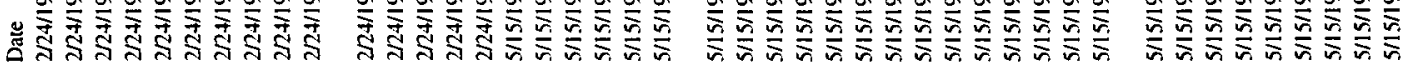

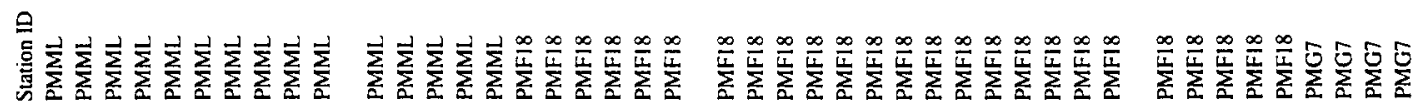

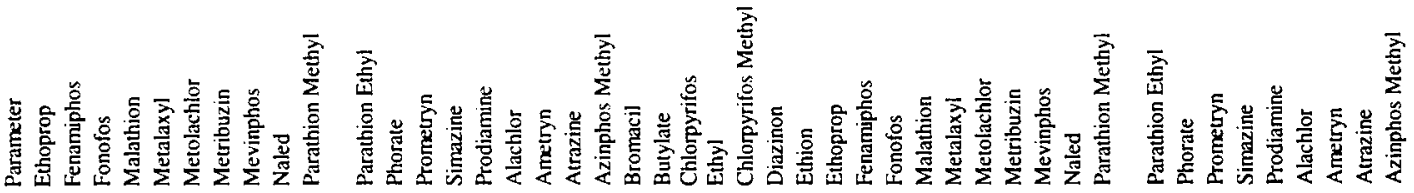

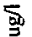

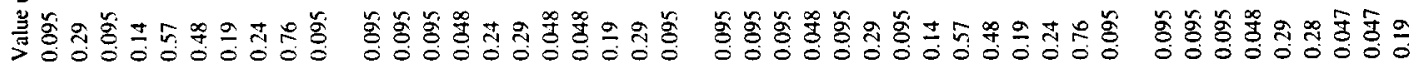

D

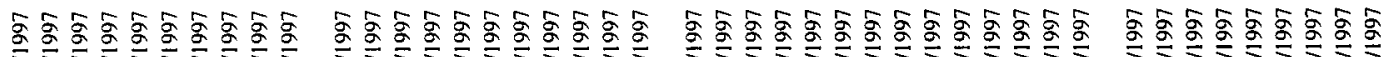

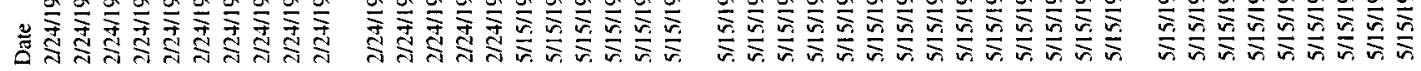

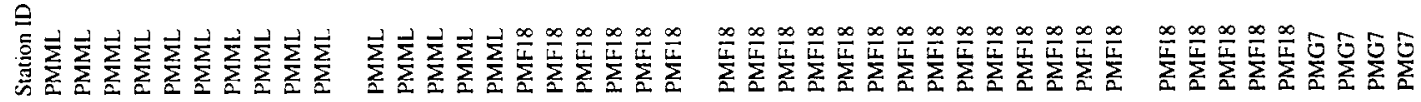


II IIMH)

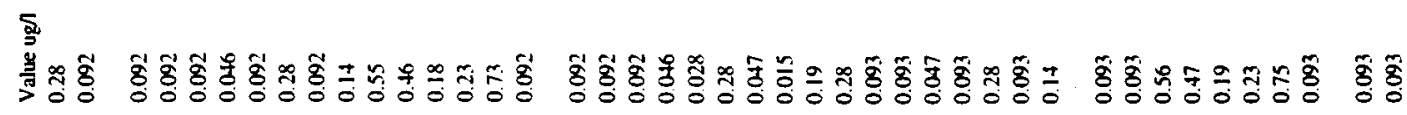

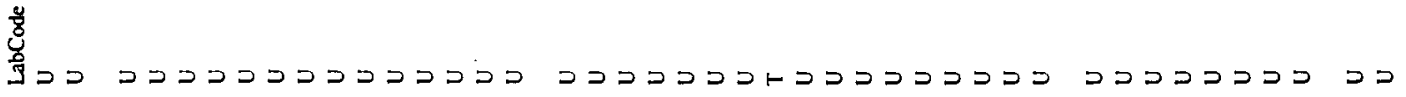

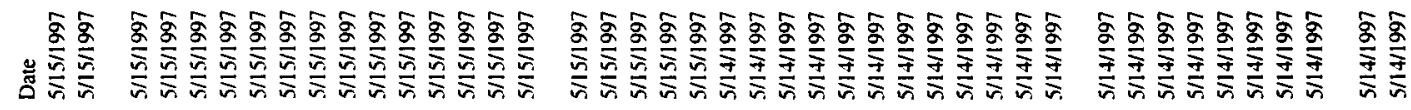

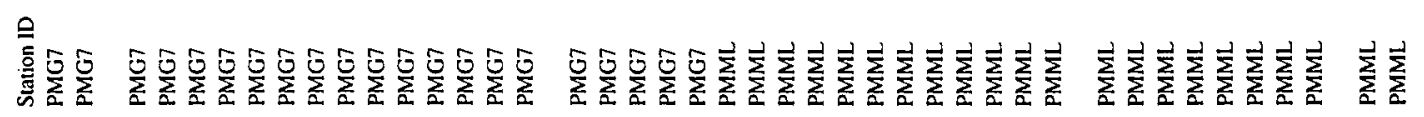

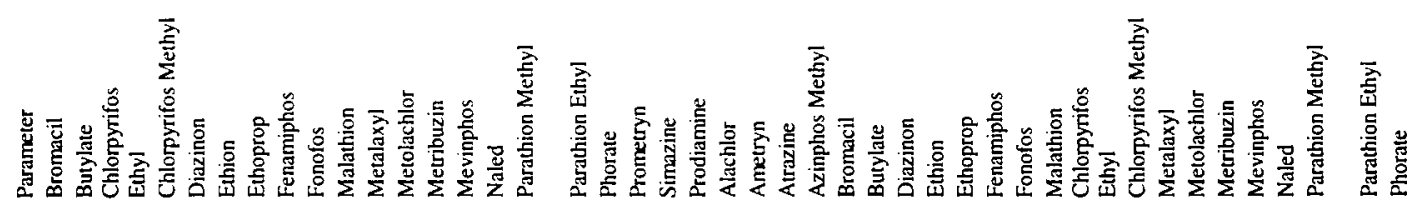

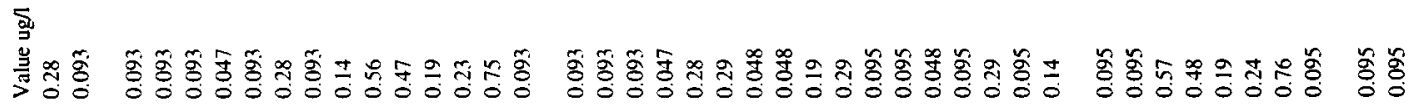

苟

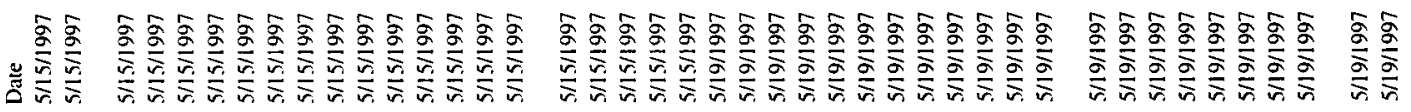

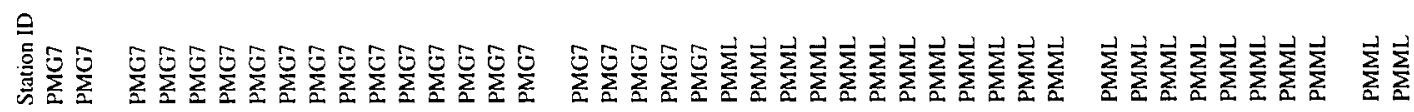


IMUIก

5

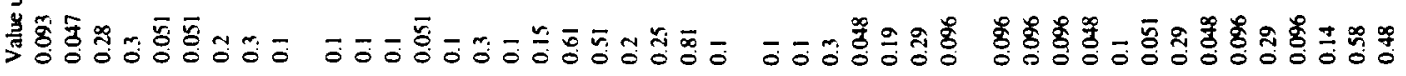

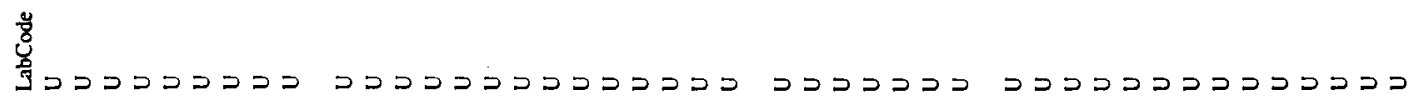

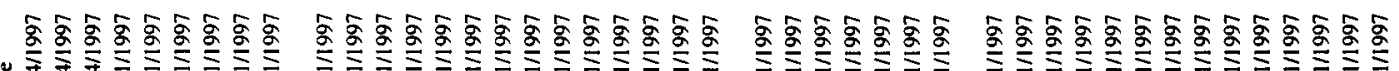

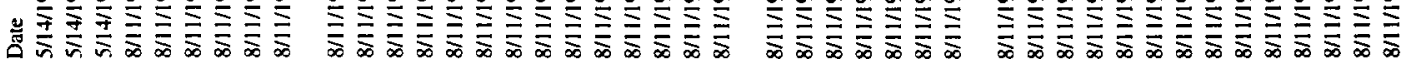

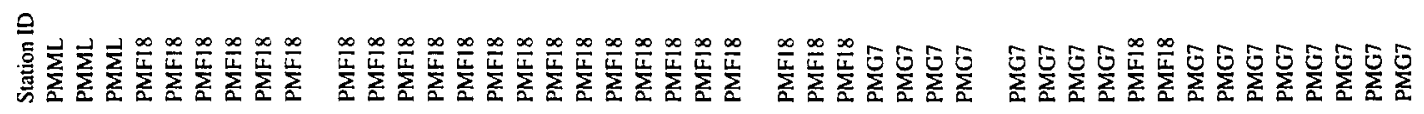

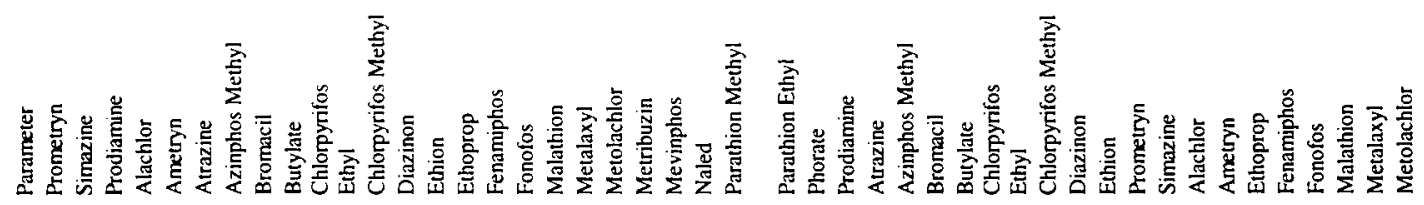

5

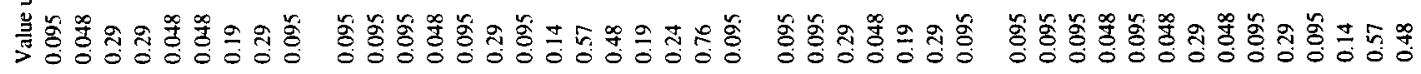

节

מכמנים

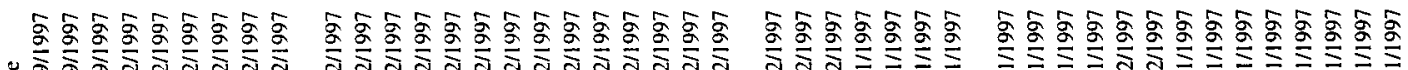

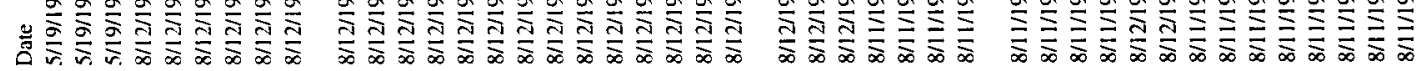

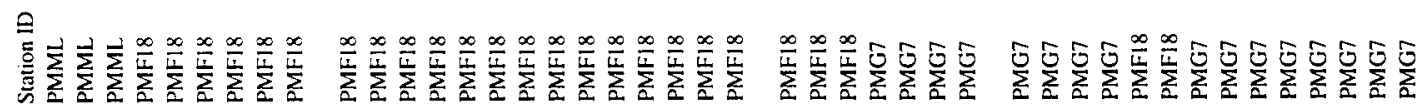




\section{MIIIIMU)}

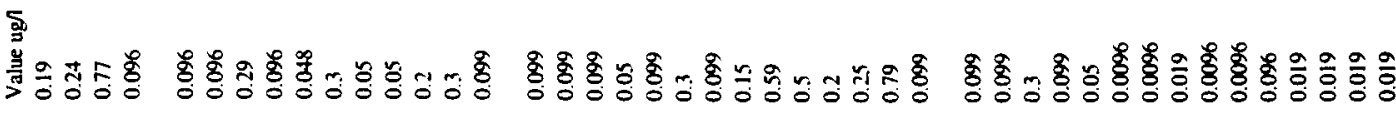

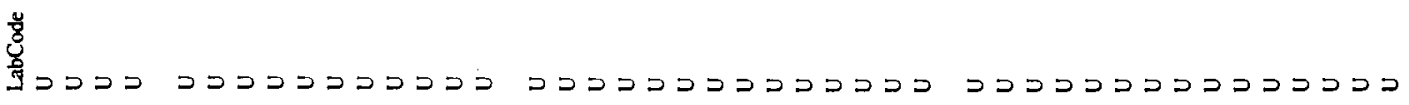

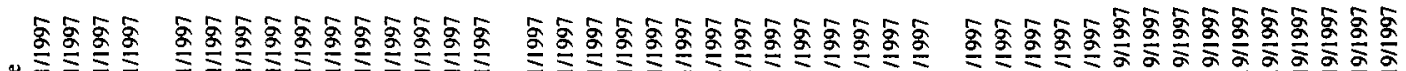

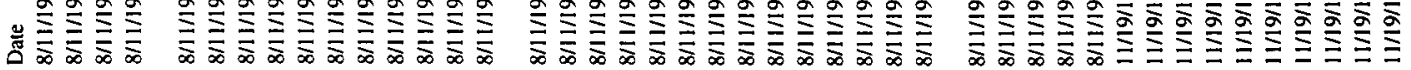

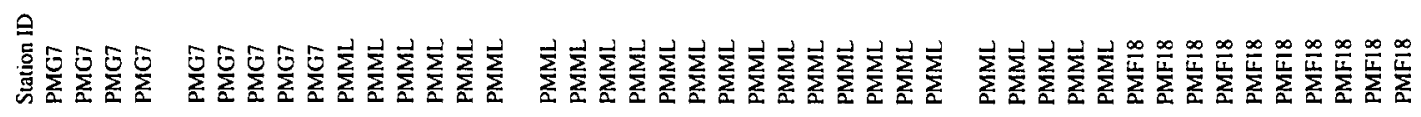

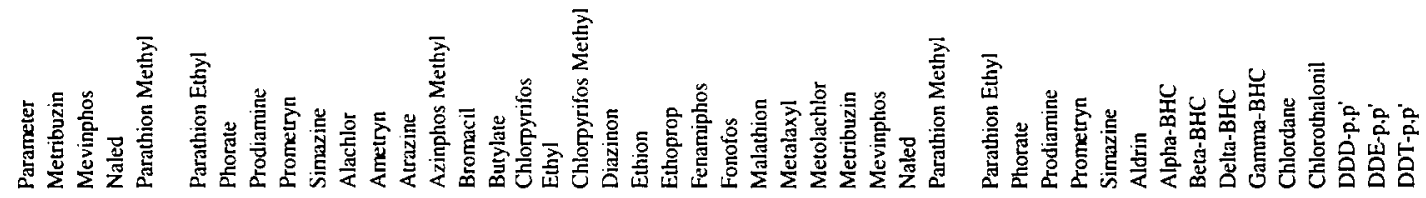

声

:

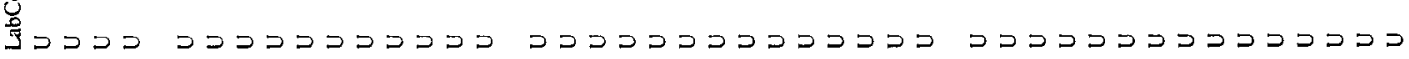

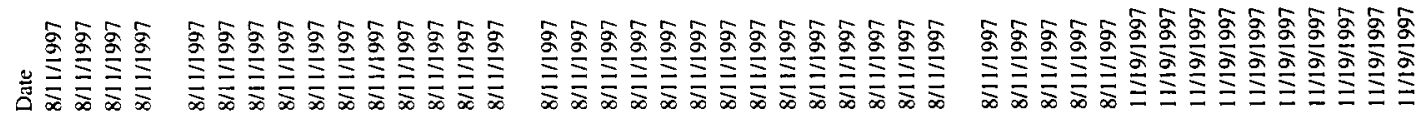

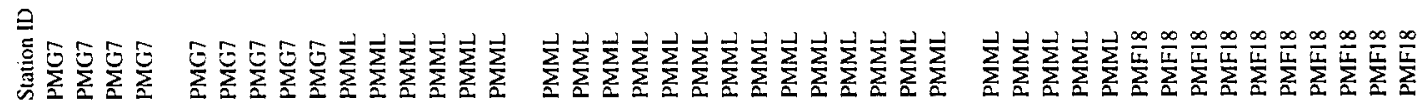


MIIIUIM

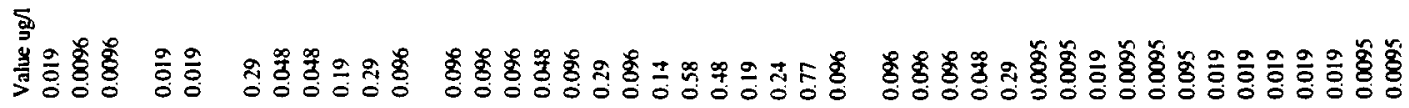

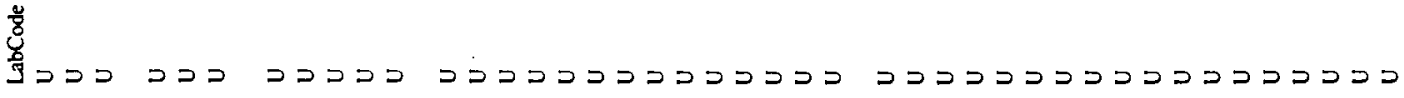

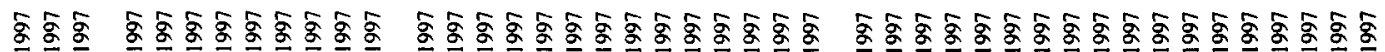

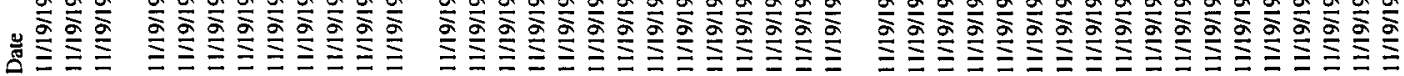

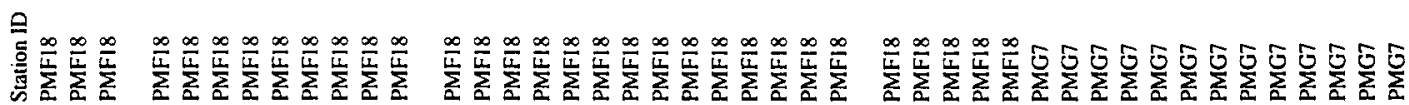

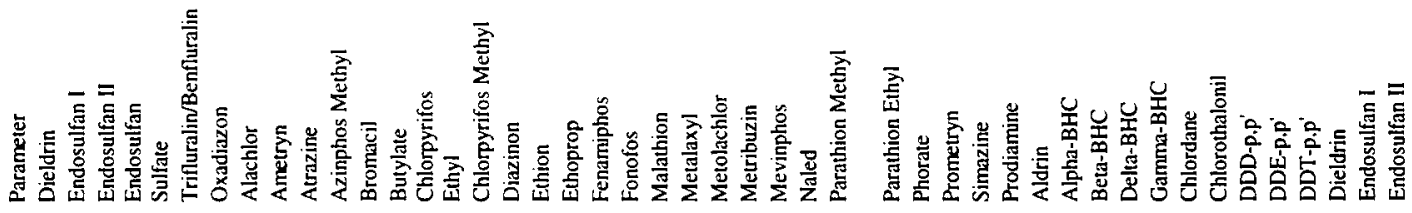

ร

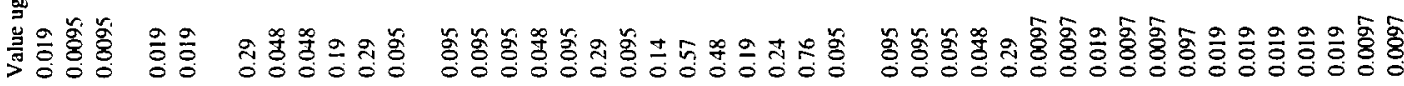

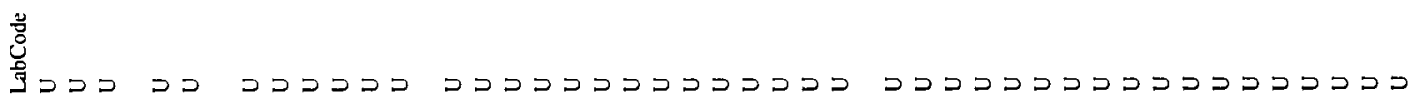

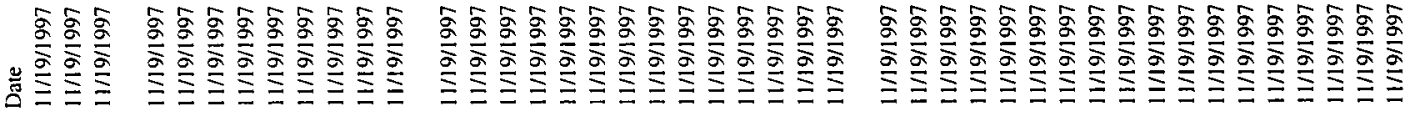

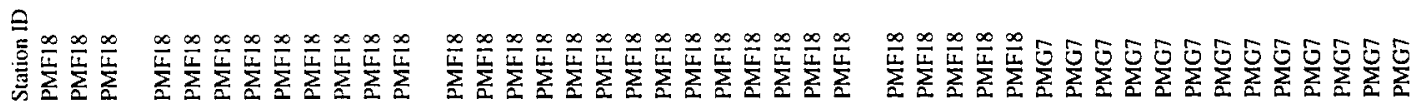




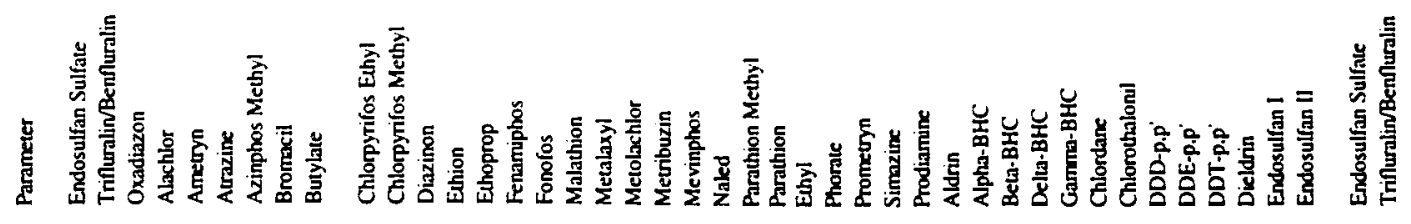

|

$\frac{1}{y}$

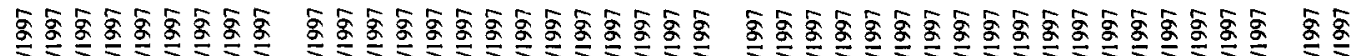

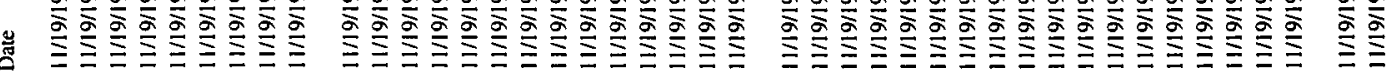

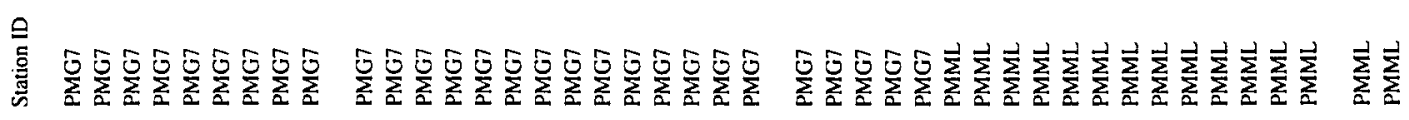

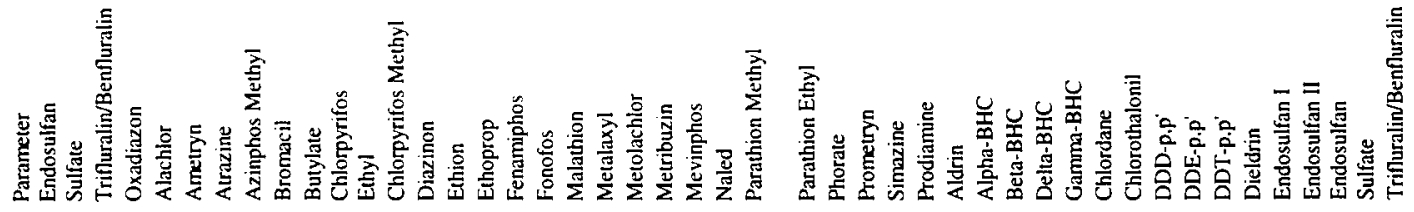

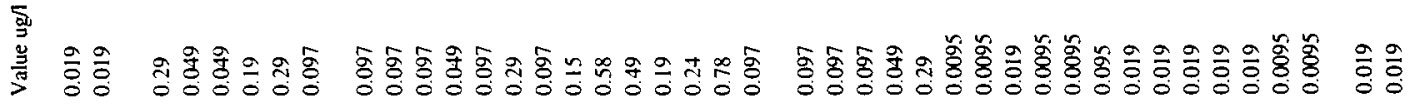

竞

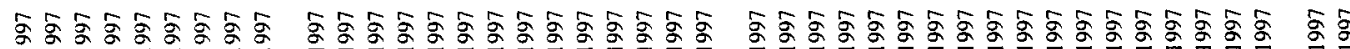

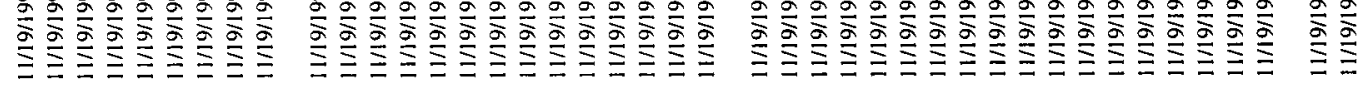

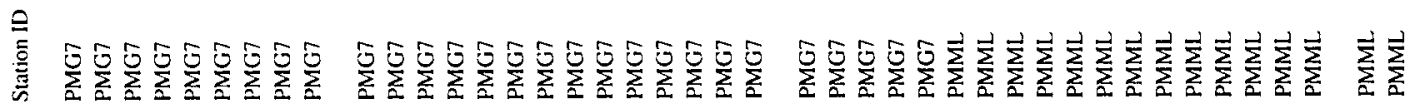




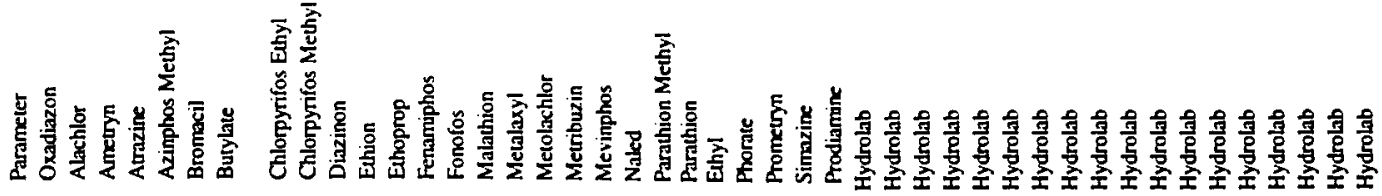

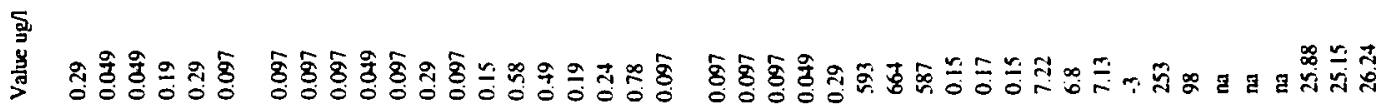
s.

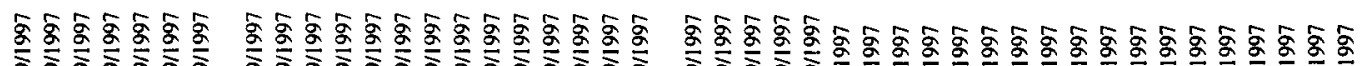

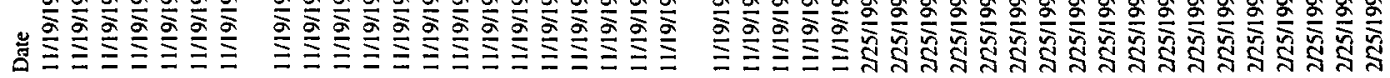

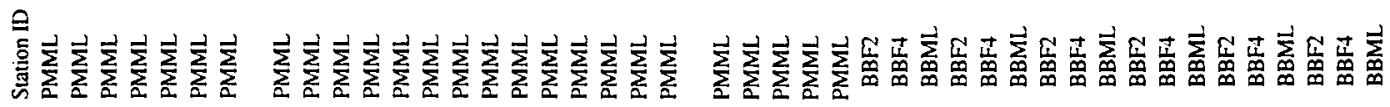

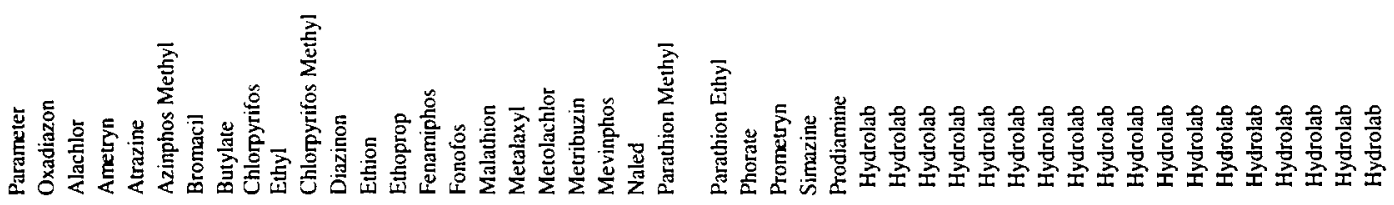

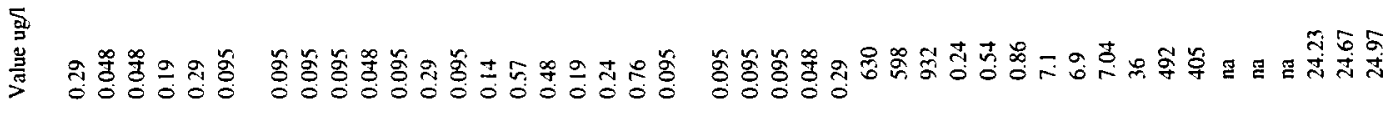

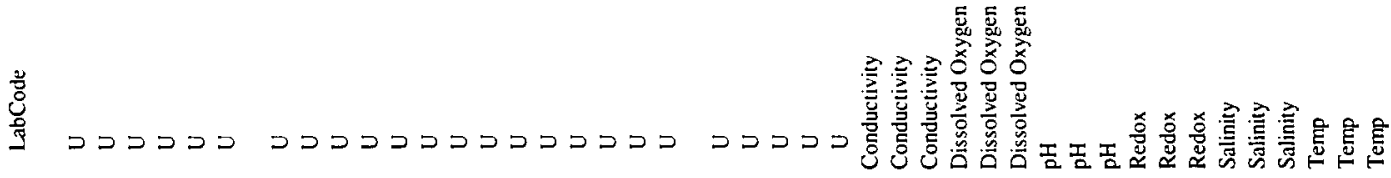

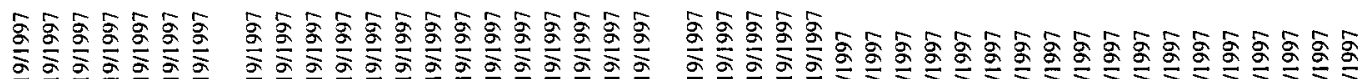

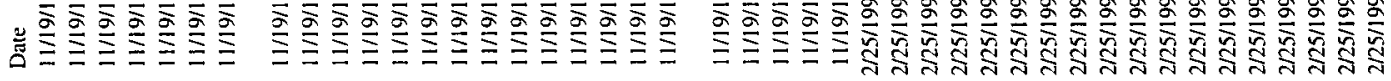

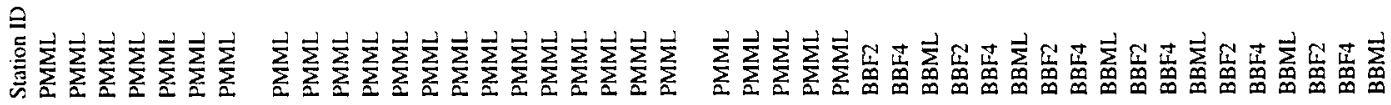




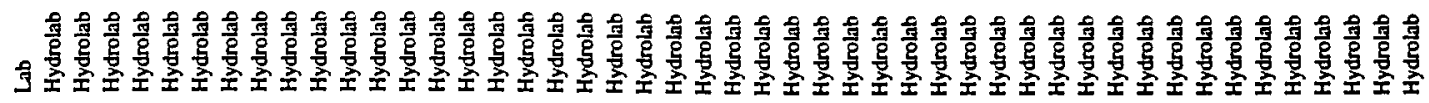

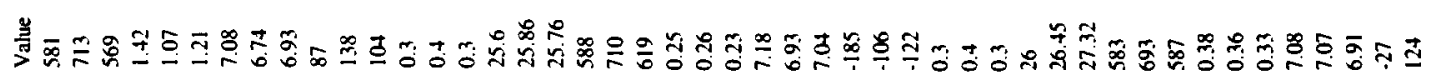

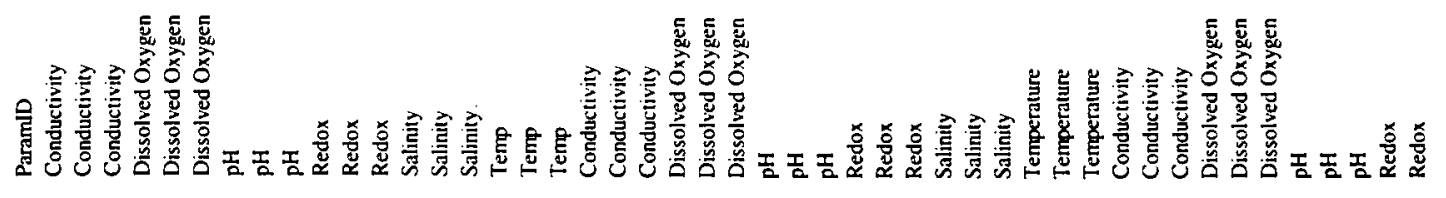

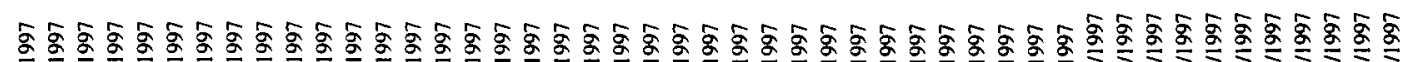

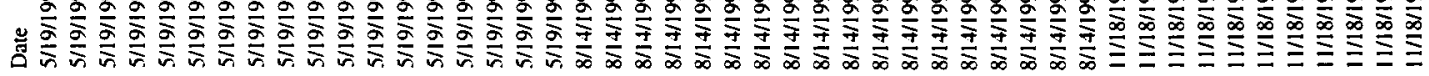

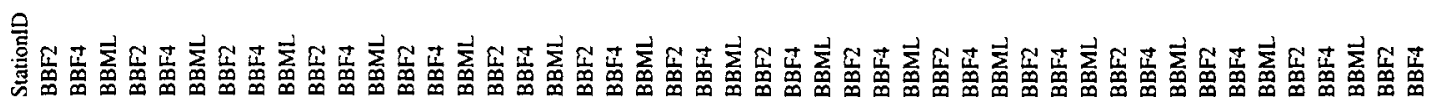

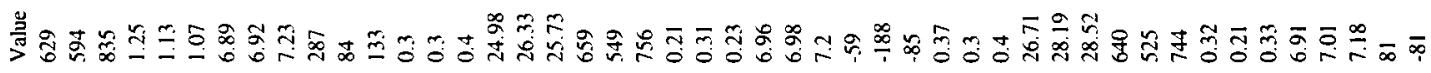

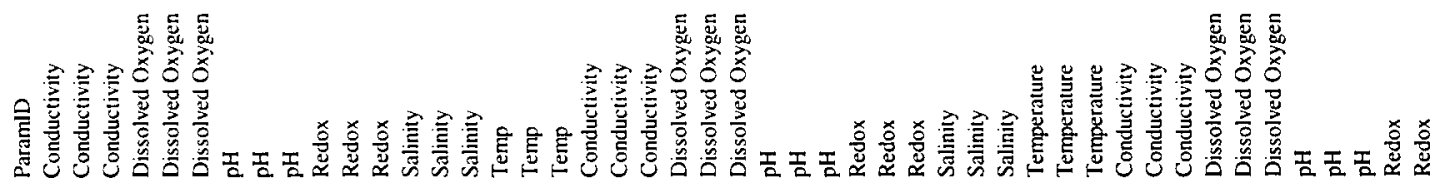

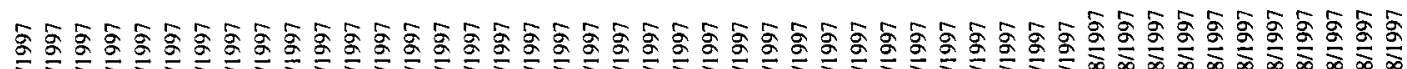

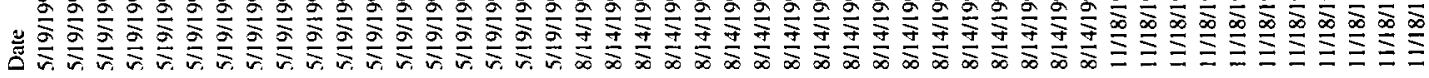

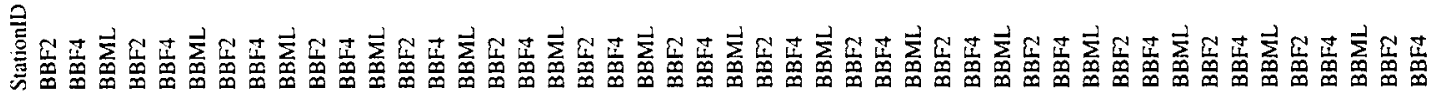




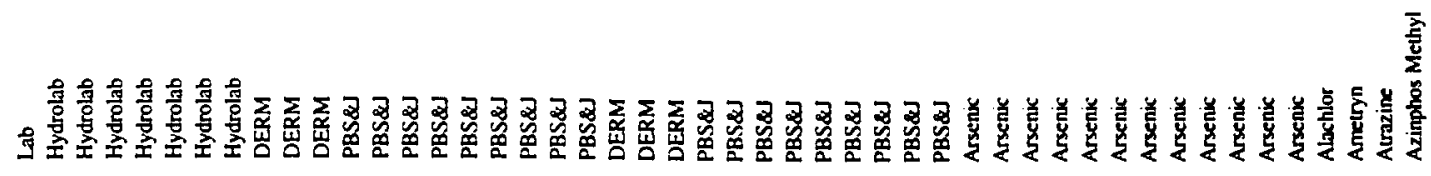

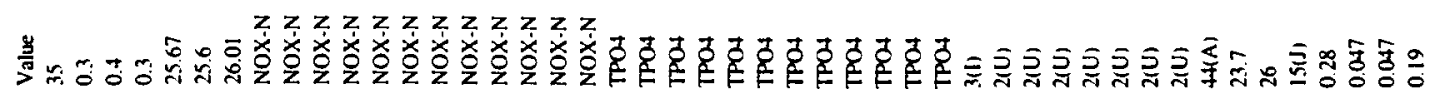

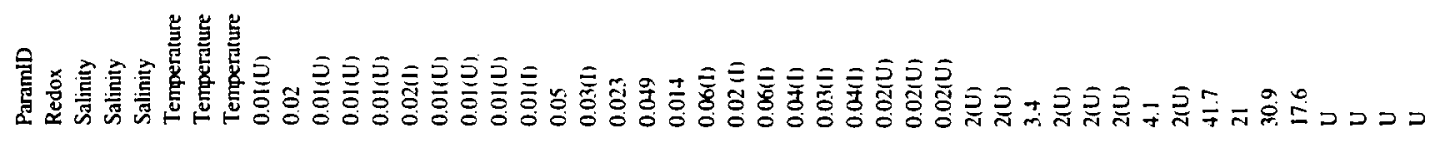

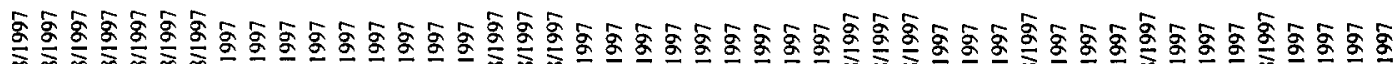

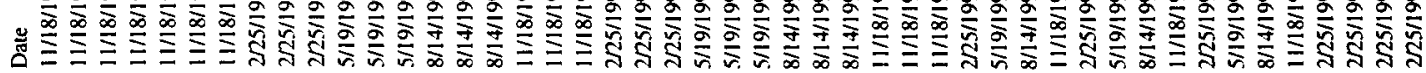

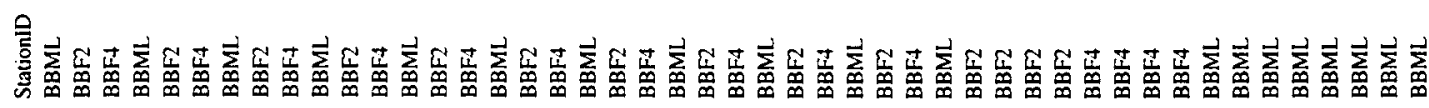

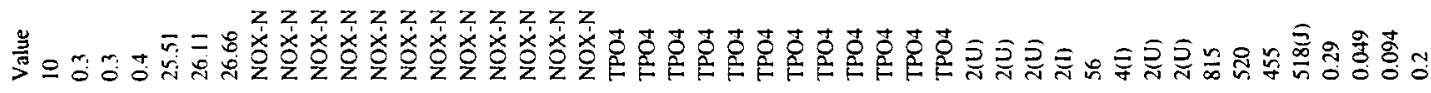

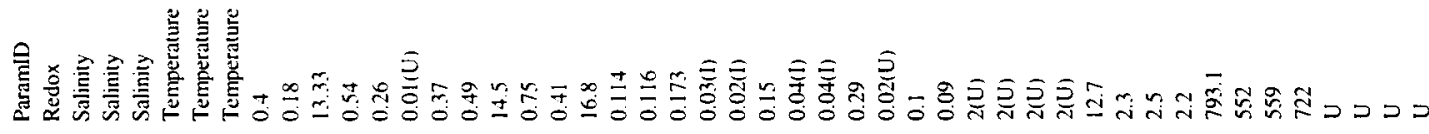

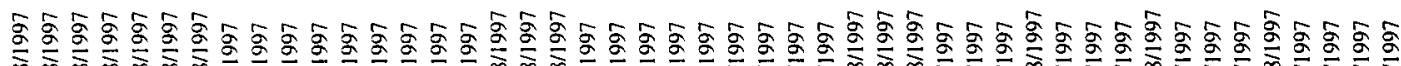

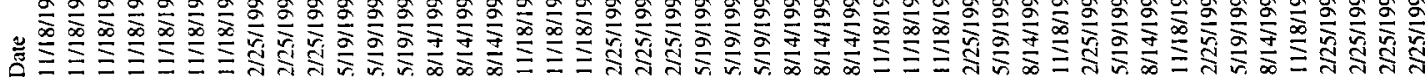

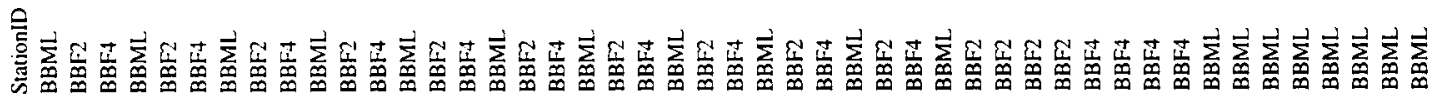




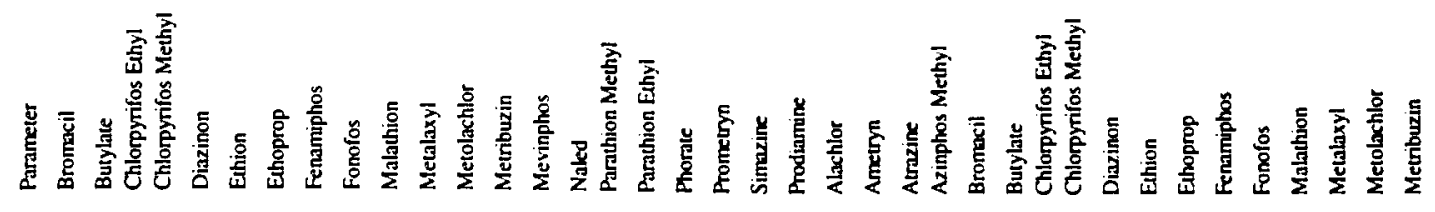

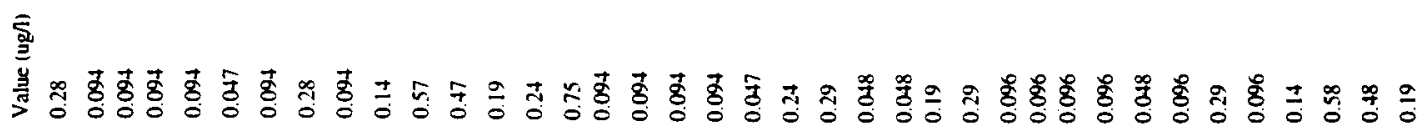

s. $\operatorname{din}$

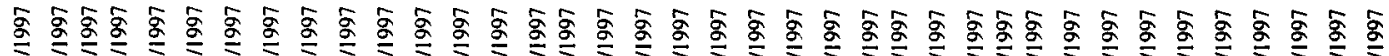

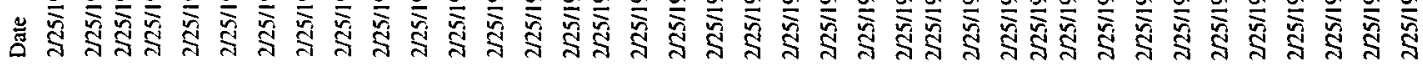

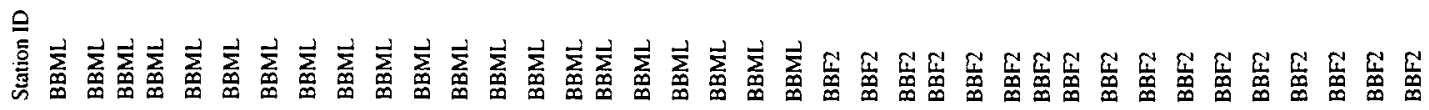

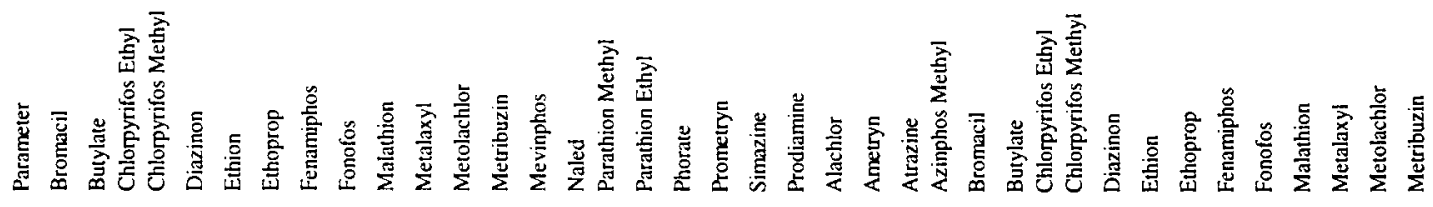
㢲

莺

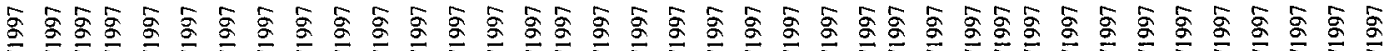

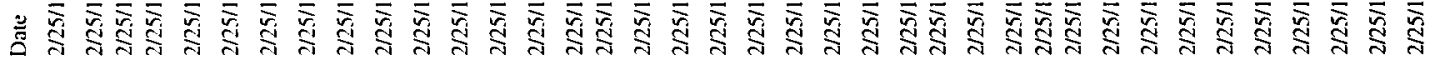

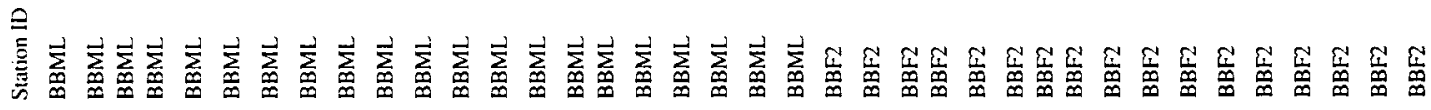




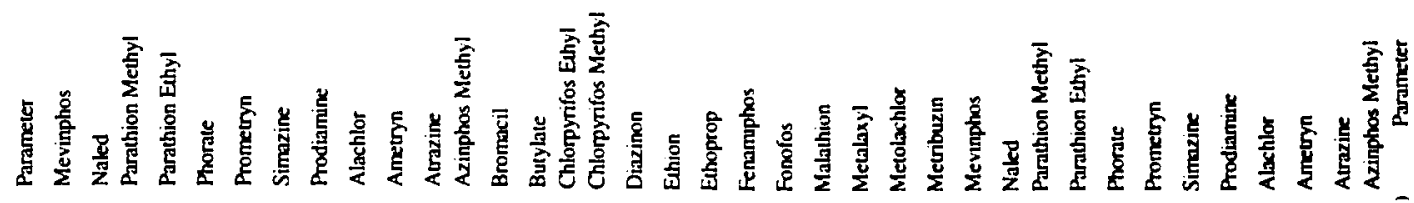

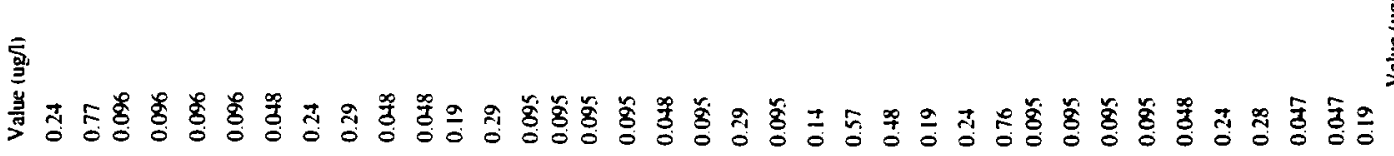

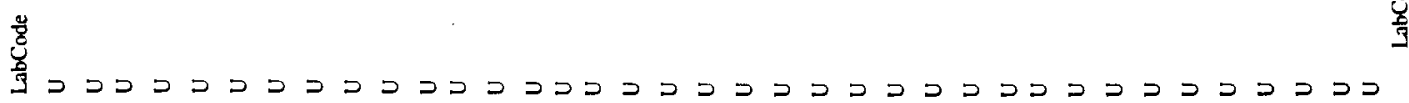

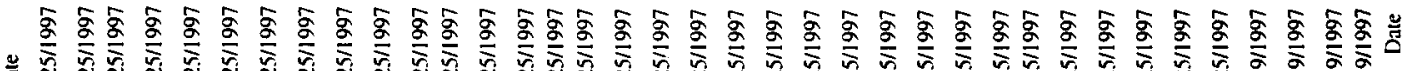

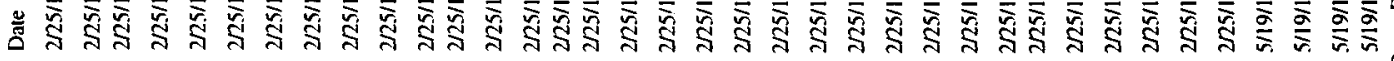

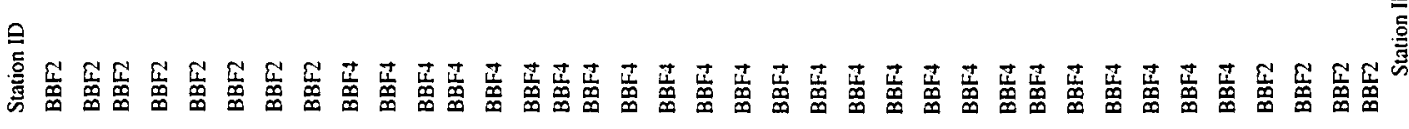

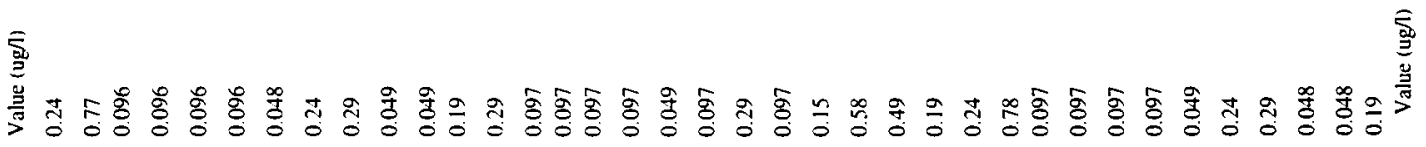

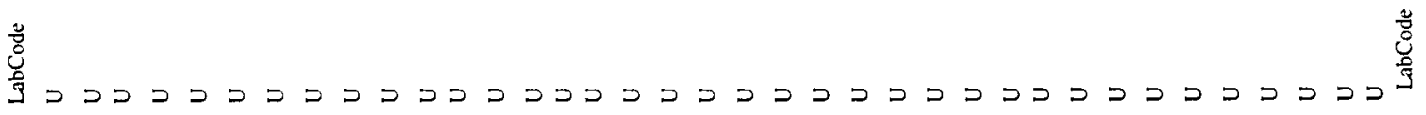

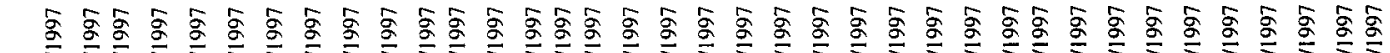

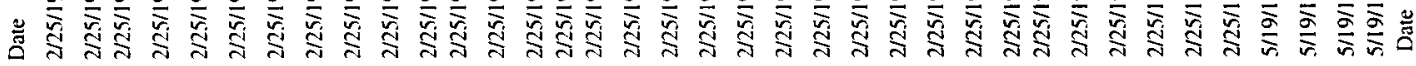

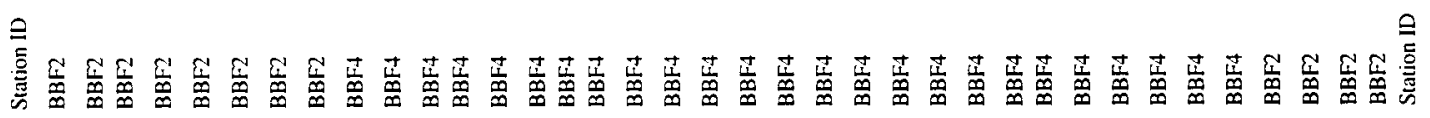




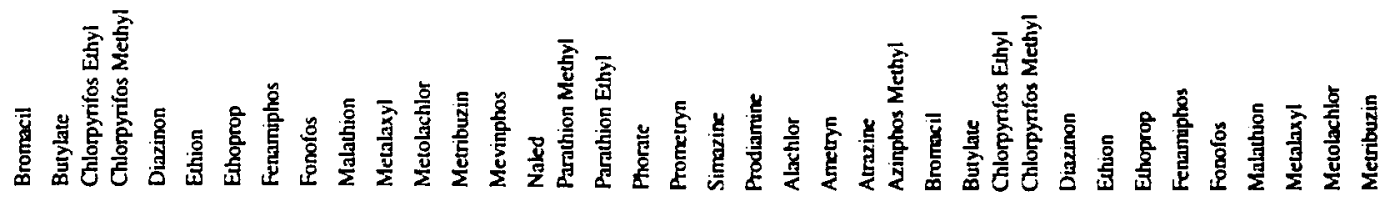

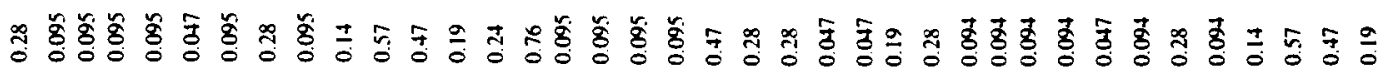

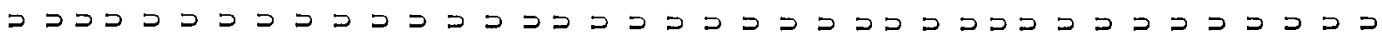

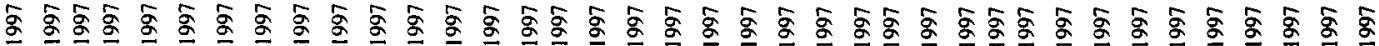

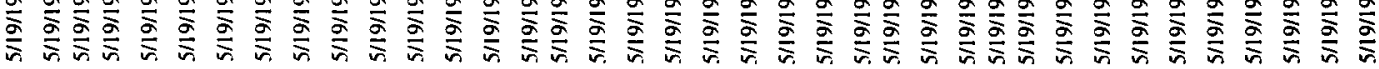

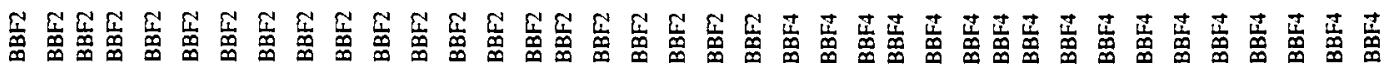

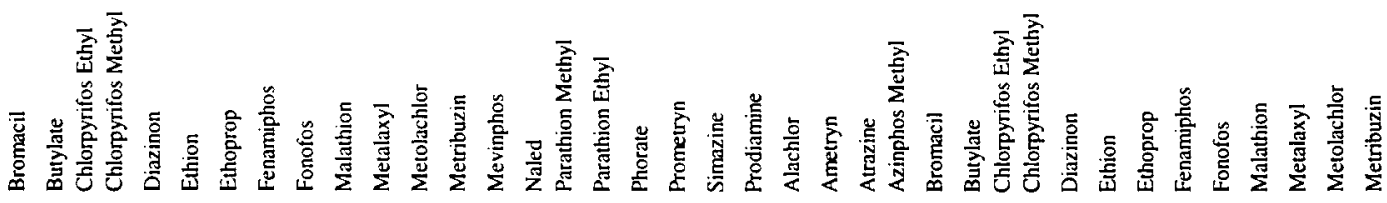

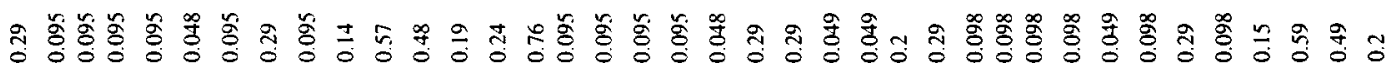

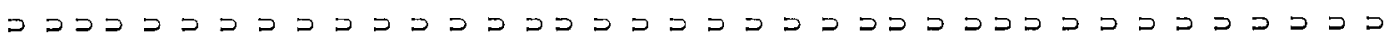

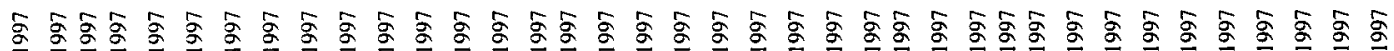

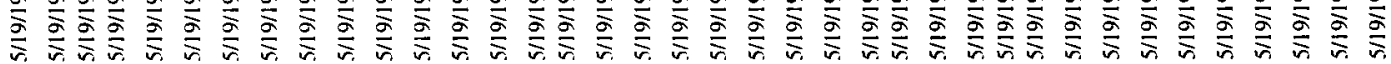

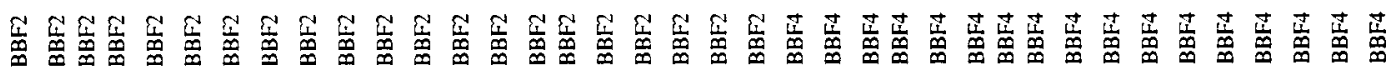




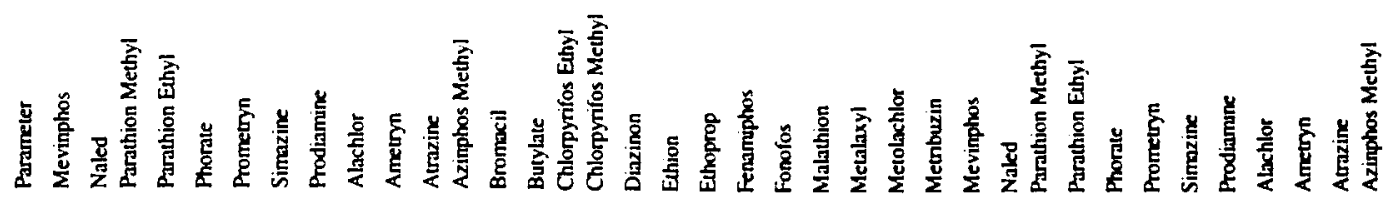

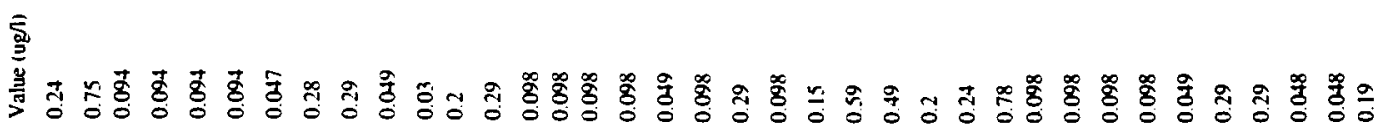

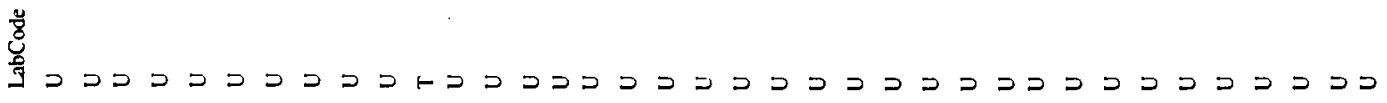

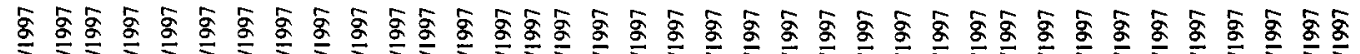

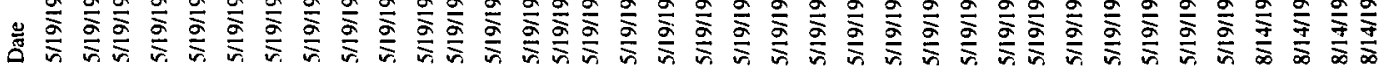

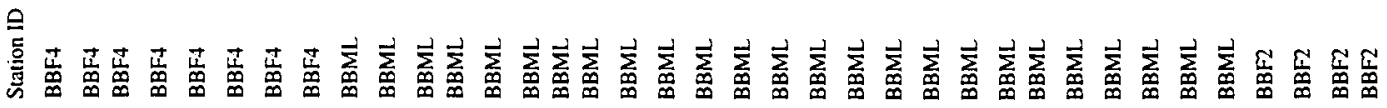

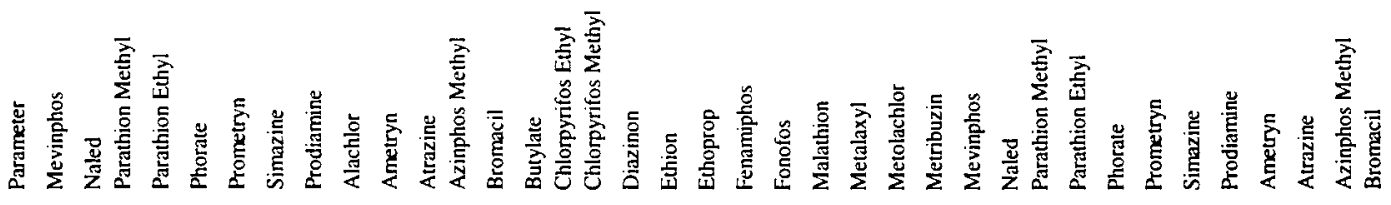
䆑

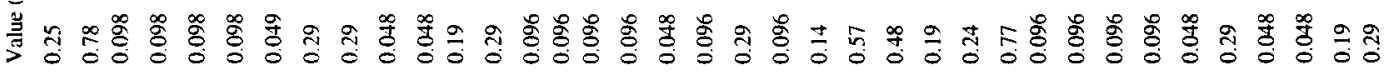

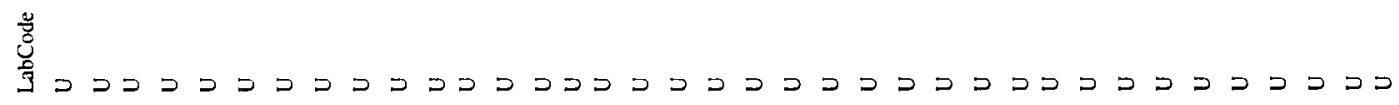
5

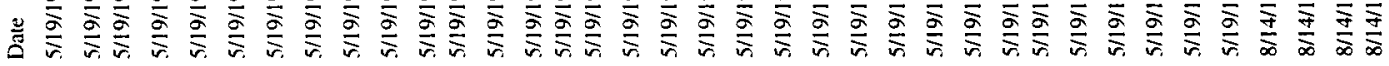

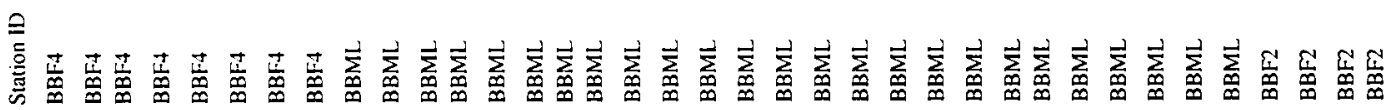




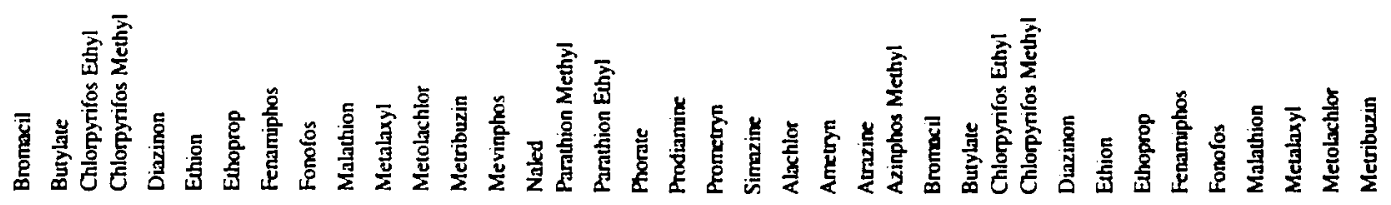

영

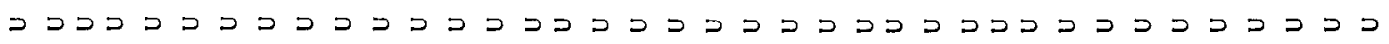

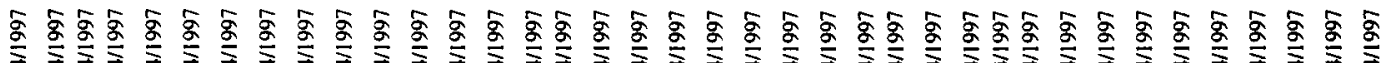

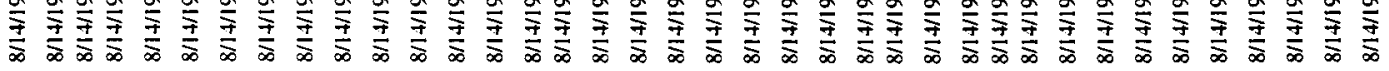

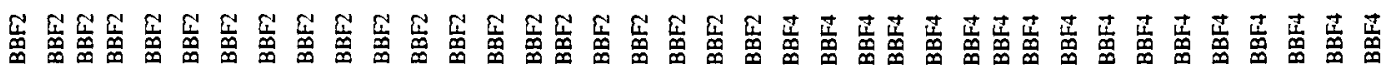

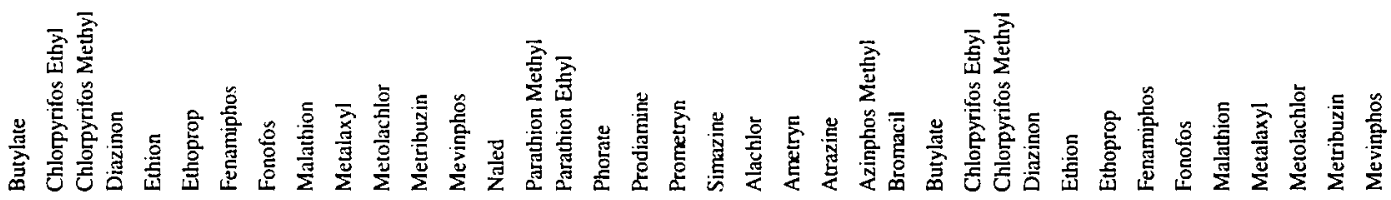

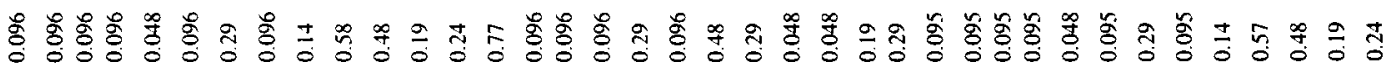

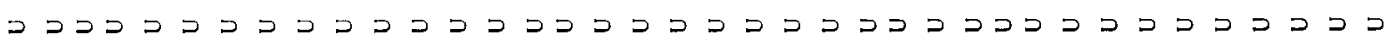

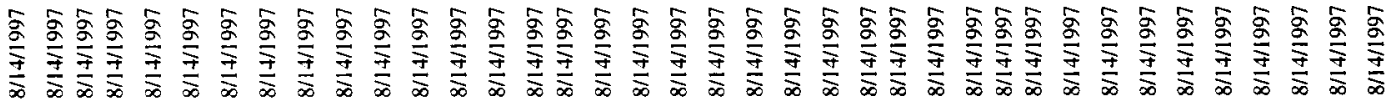

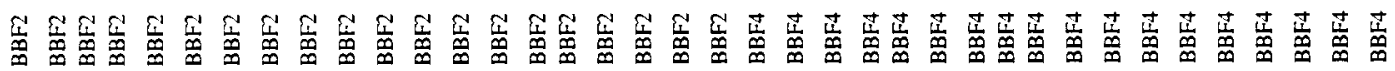




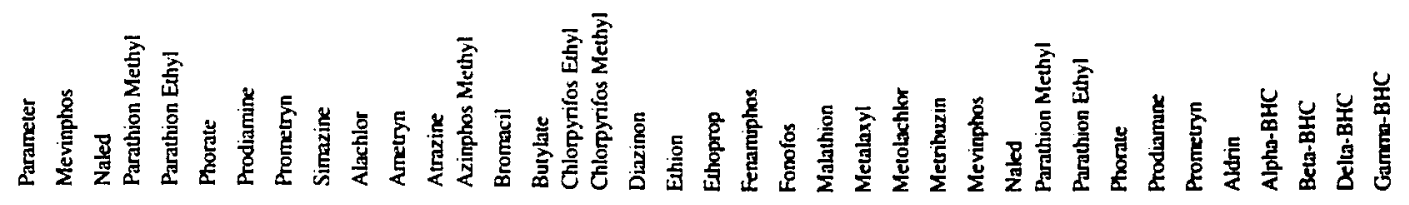

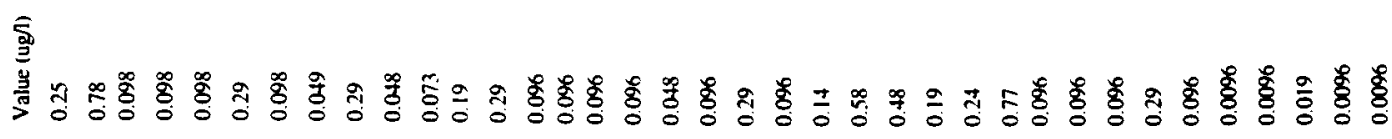

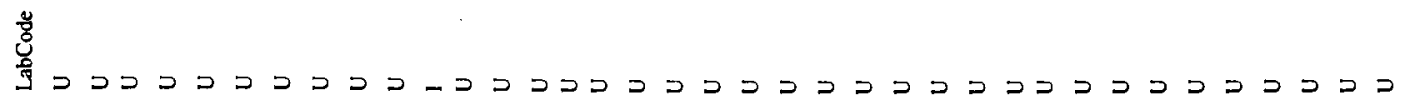

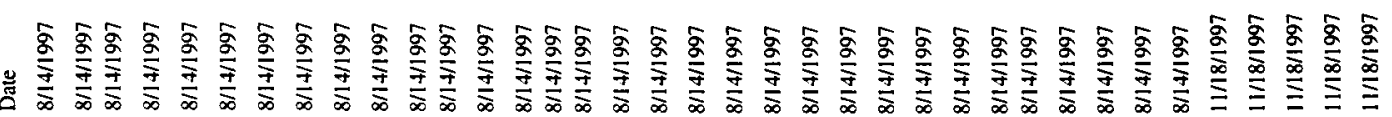

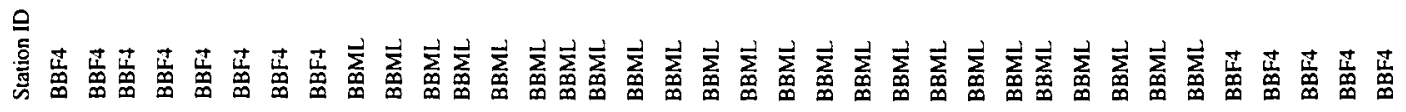

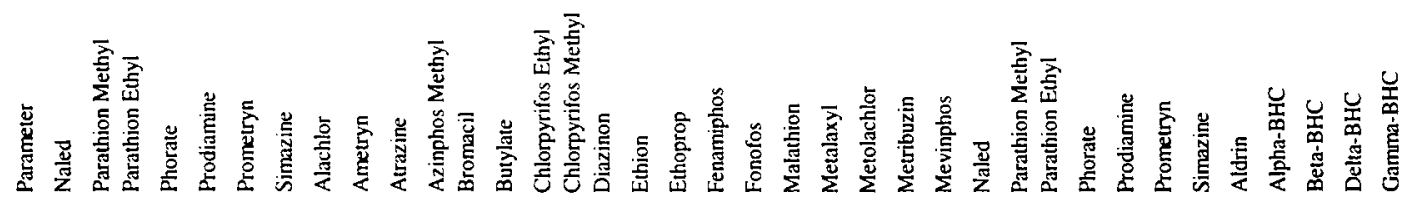

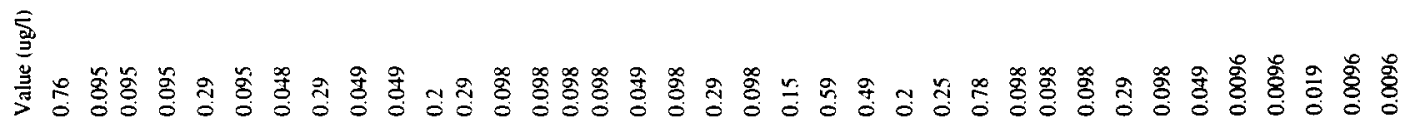

VI.

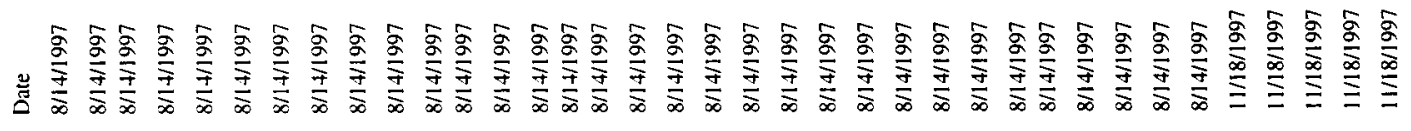

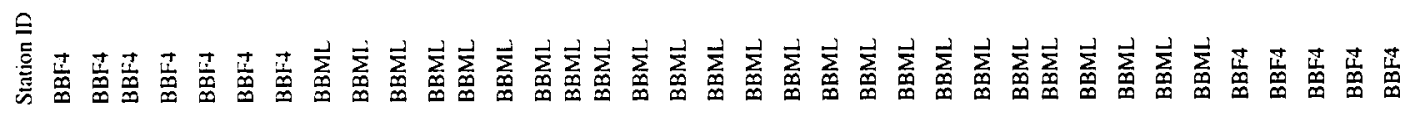




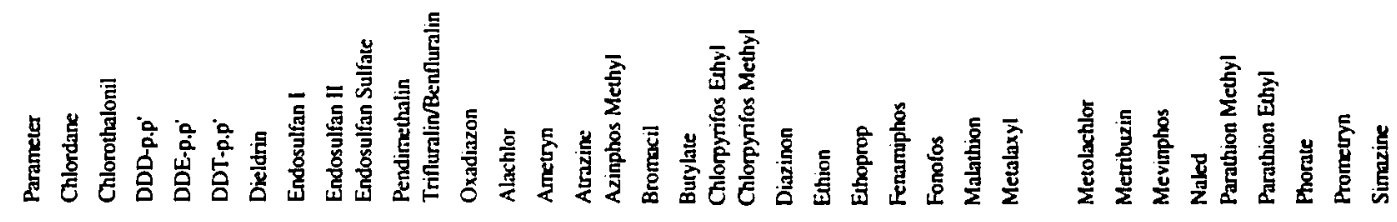

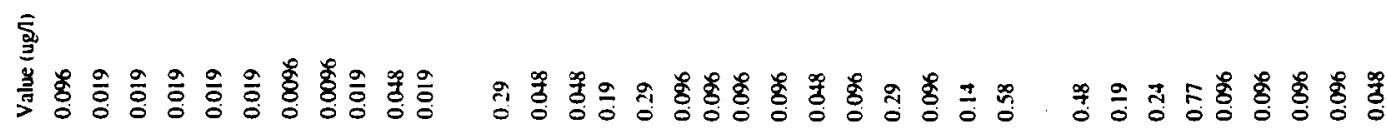
娄

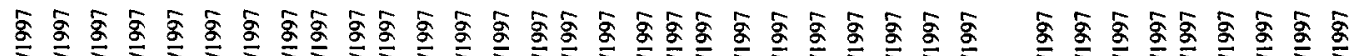

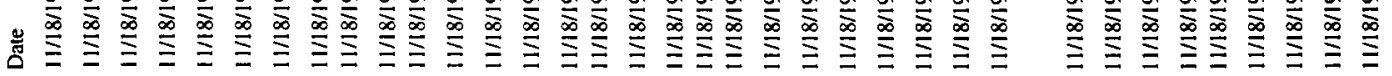

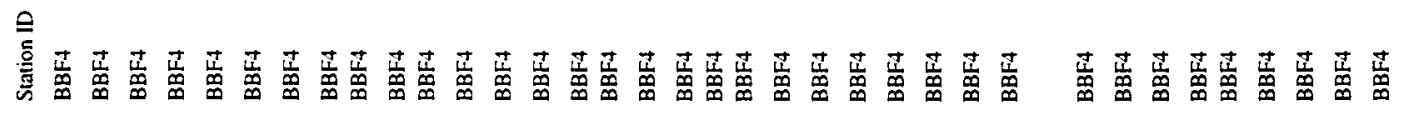

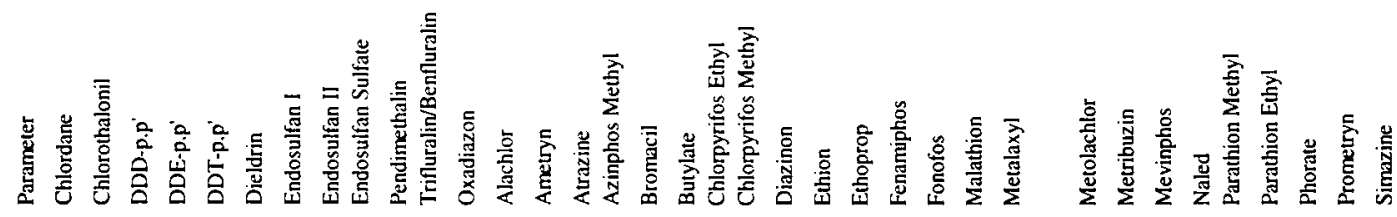

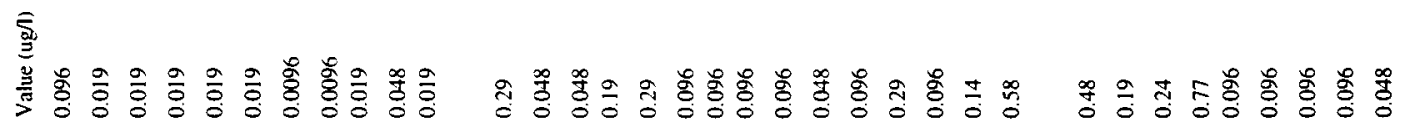

竞 疍

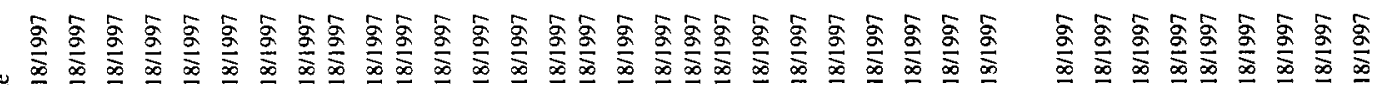

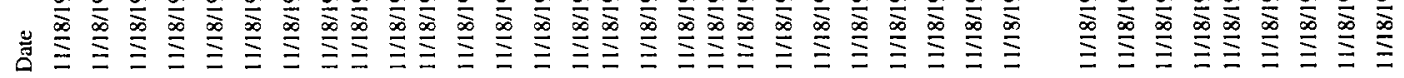

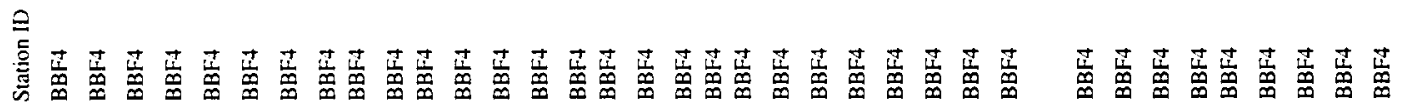




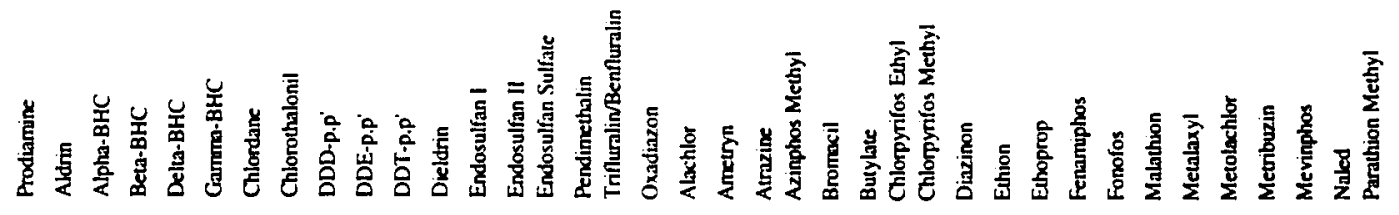

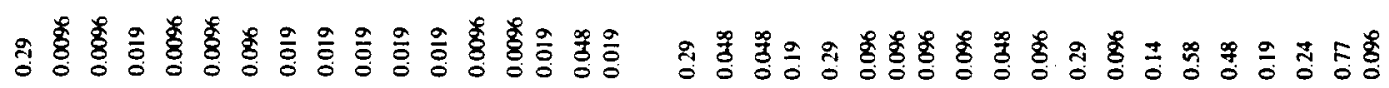

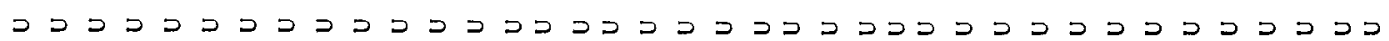

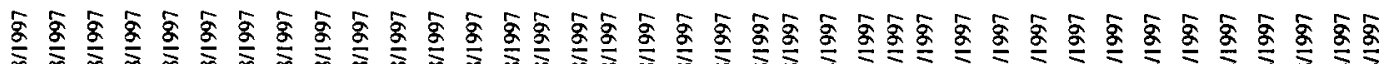

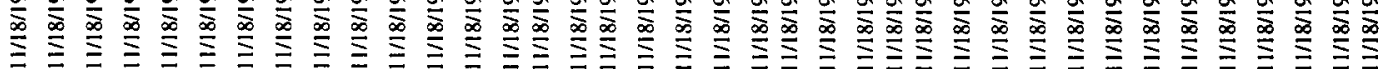

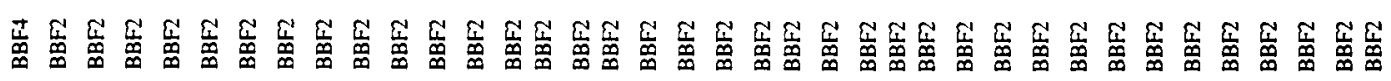

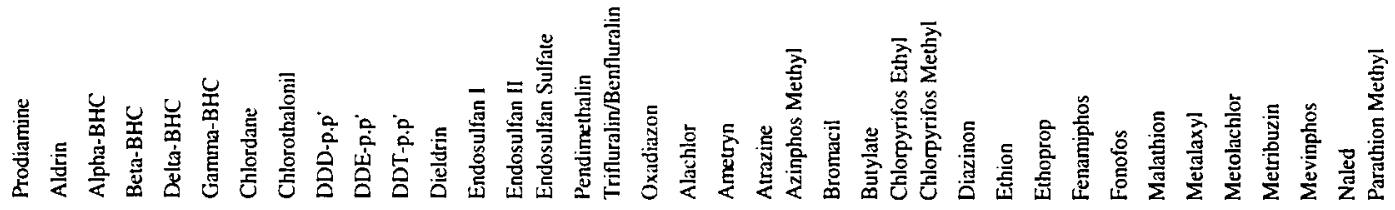

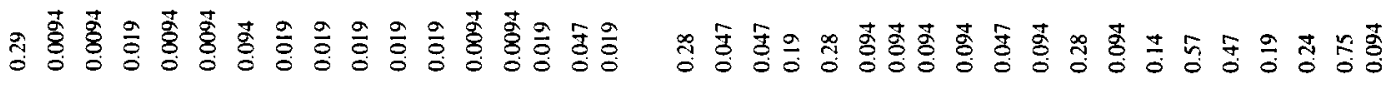

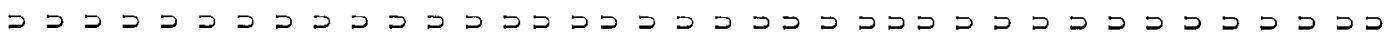

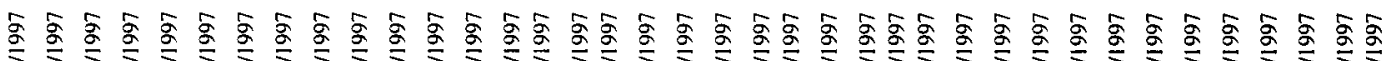

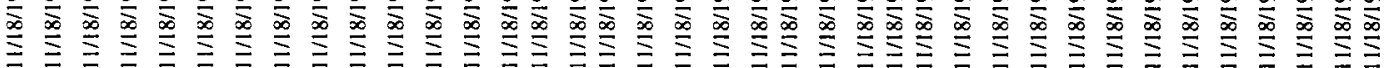

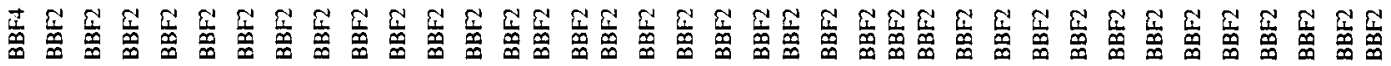




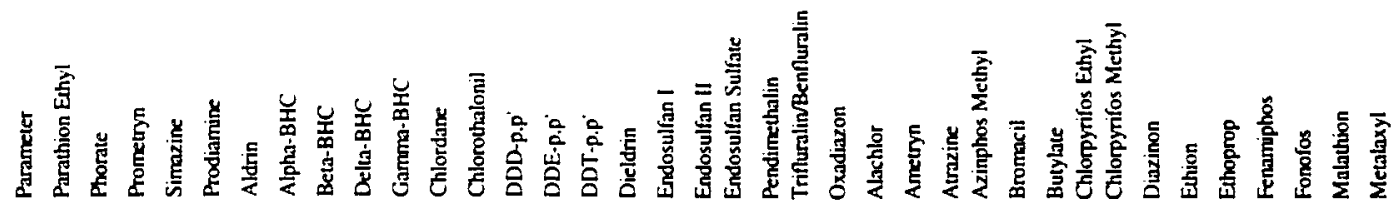

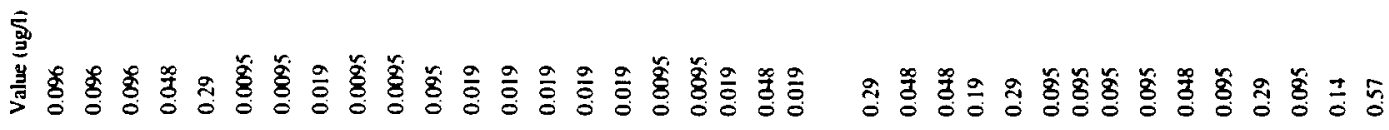

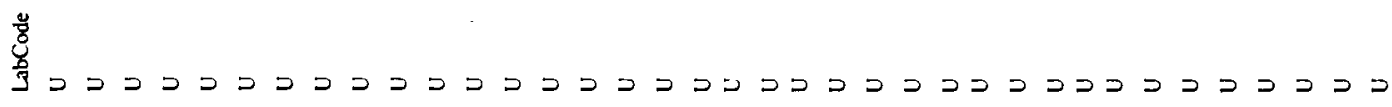

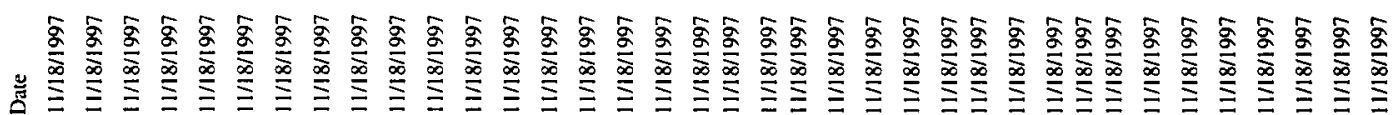

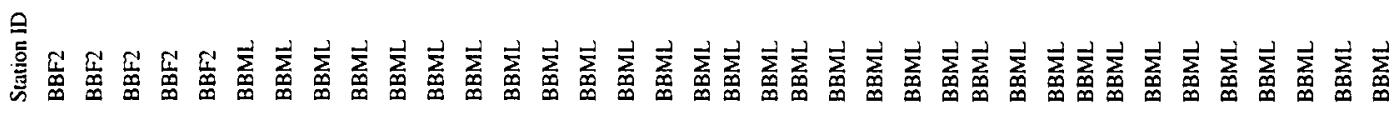

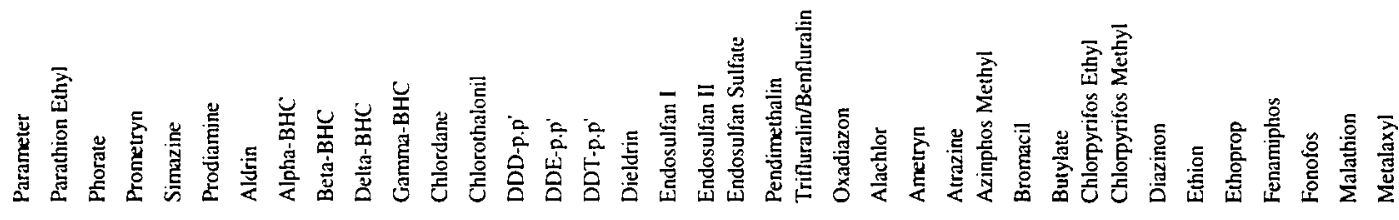
㽰

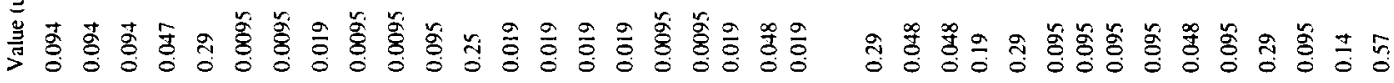

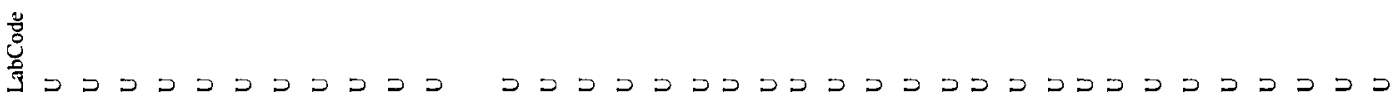

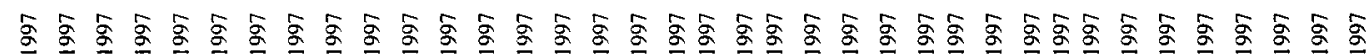

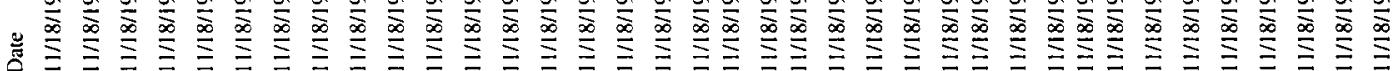

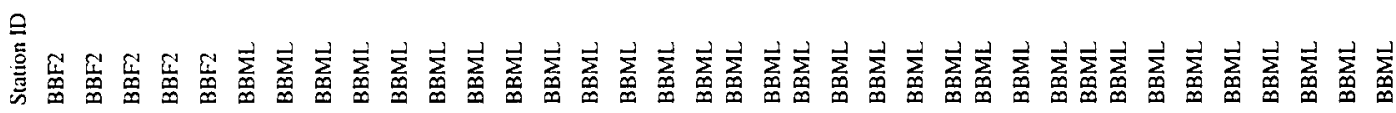




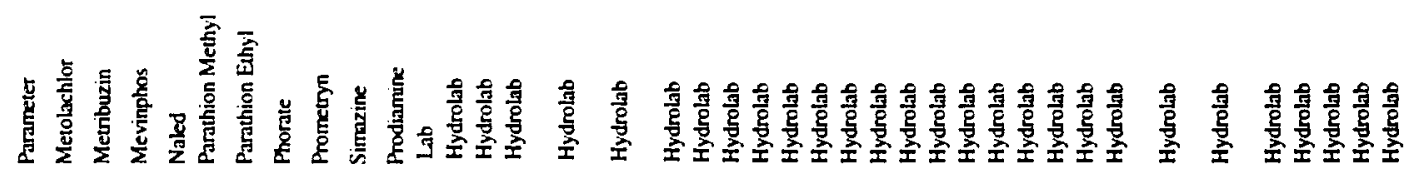

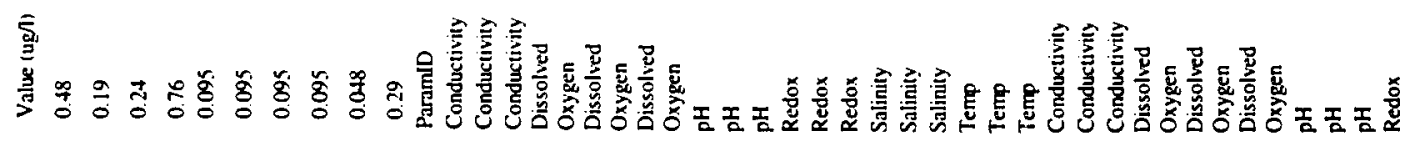

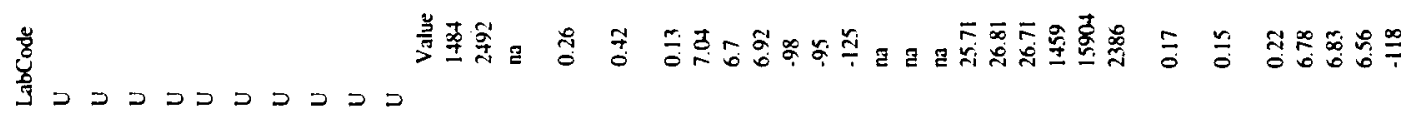

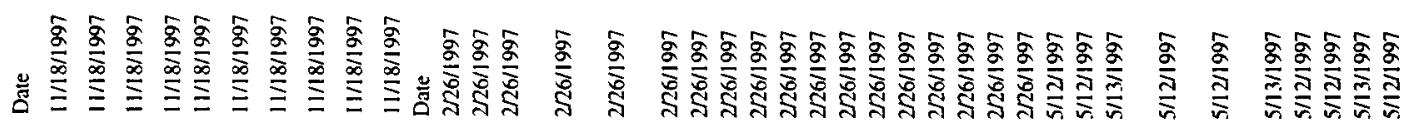

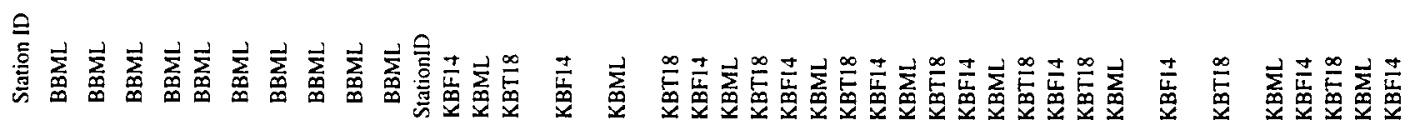

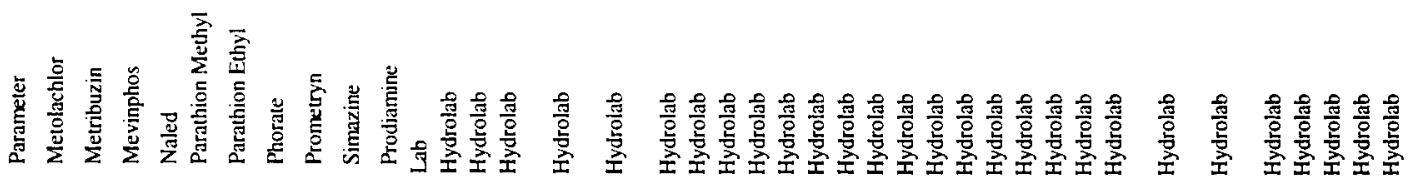

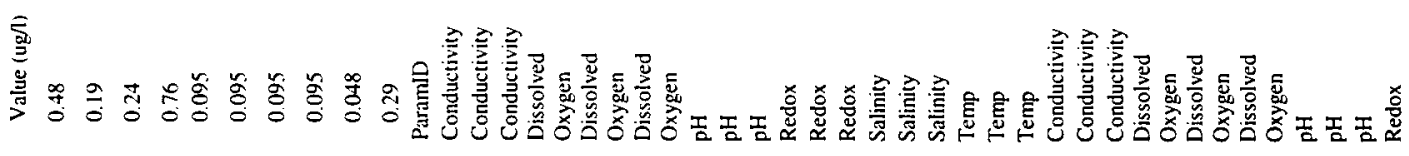
章

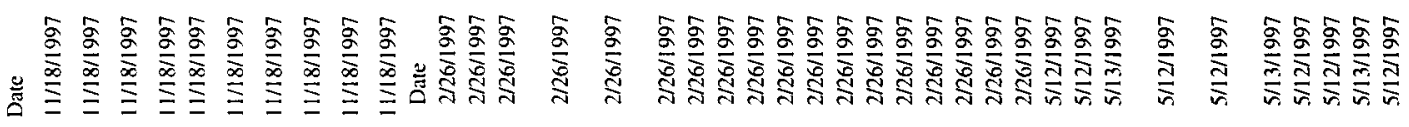

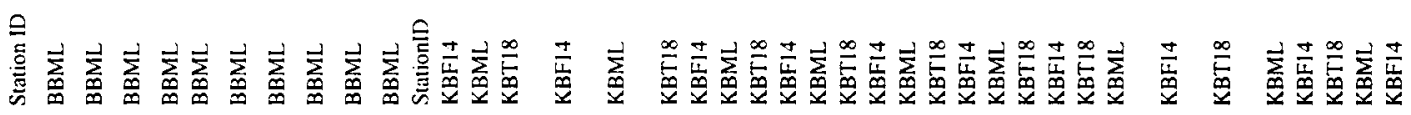




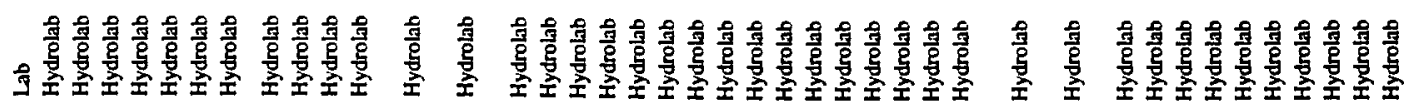

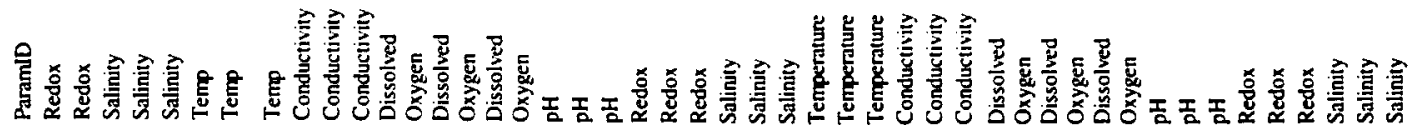

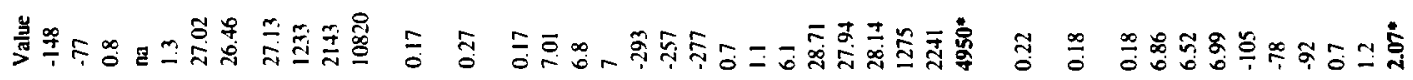

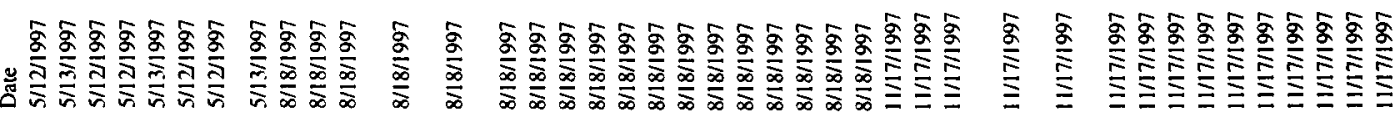

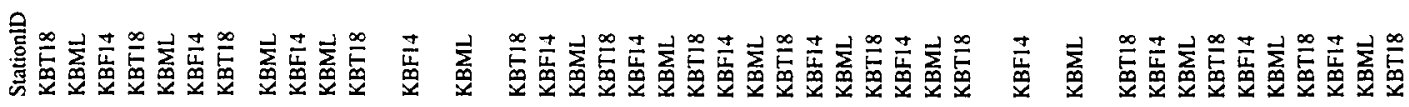

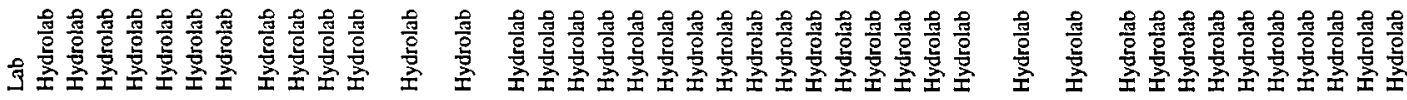

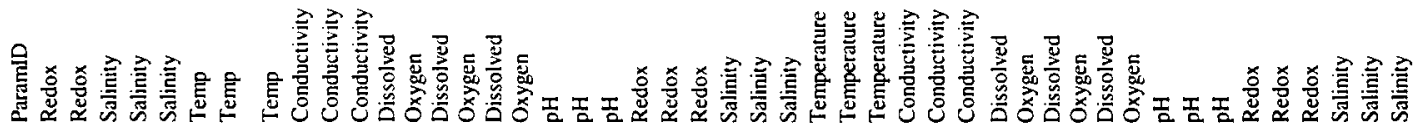

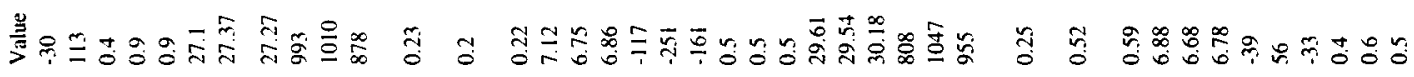

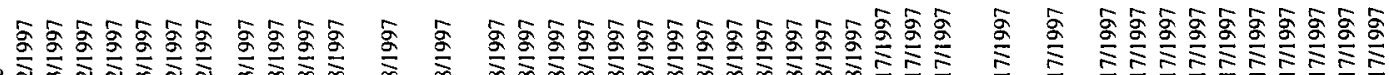

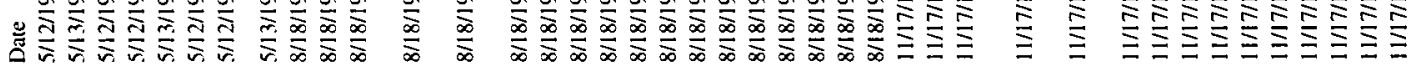

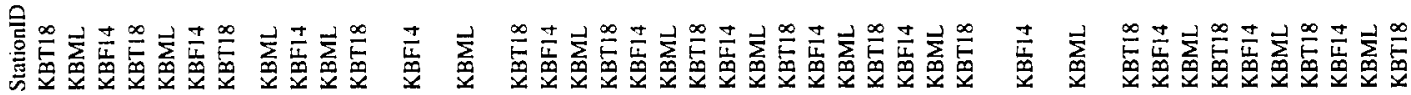




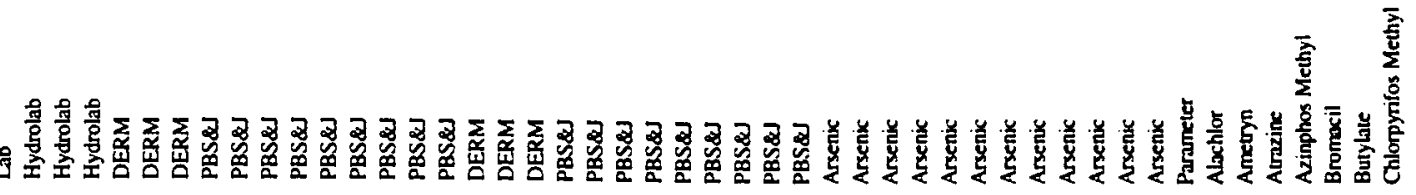

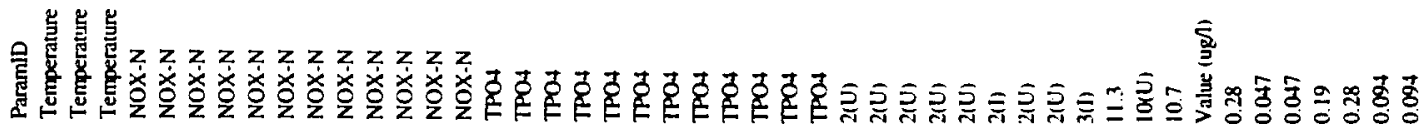

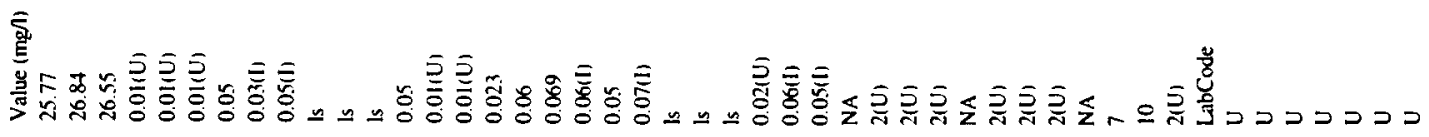

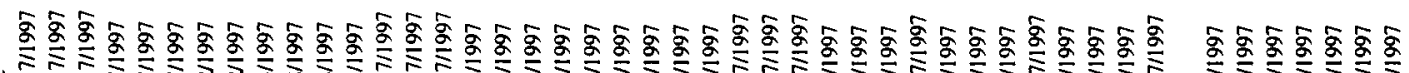

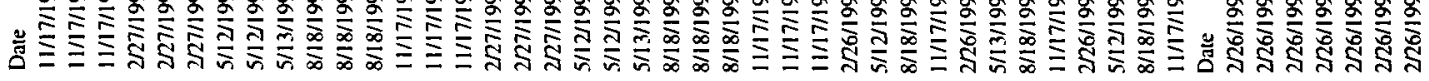

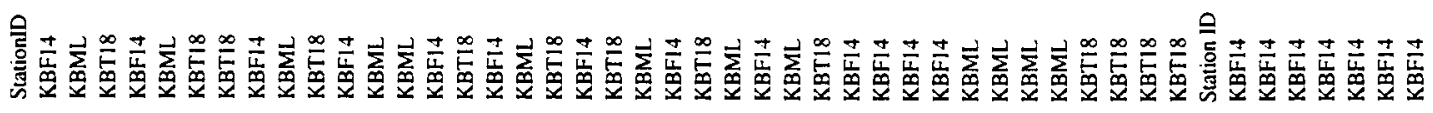

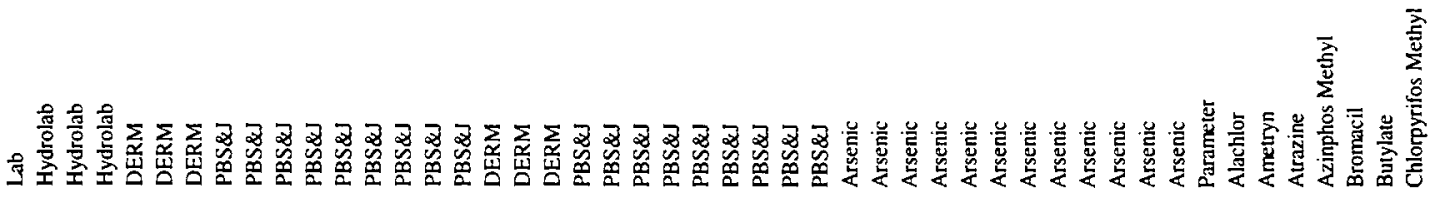

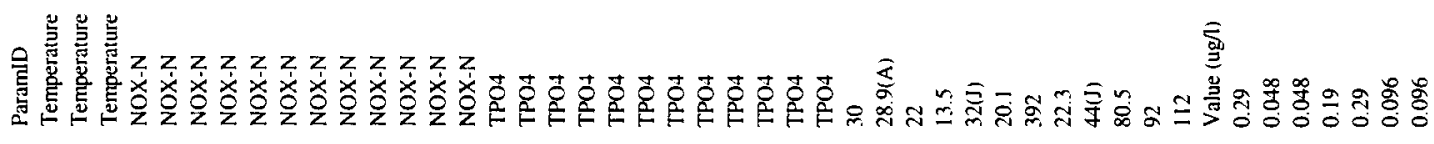
s.

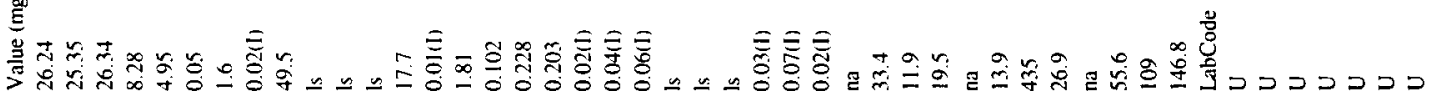

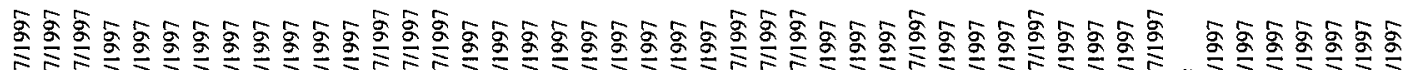

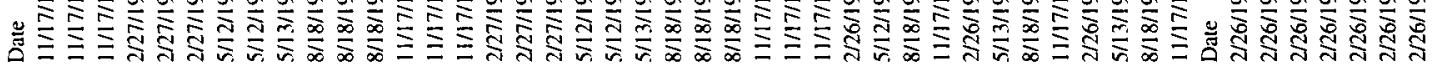

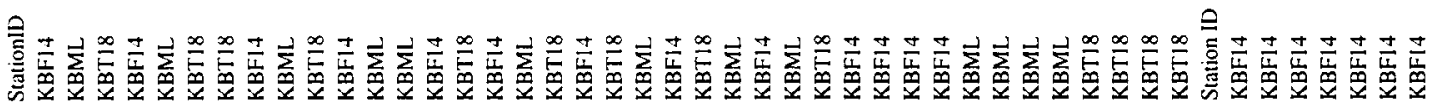




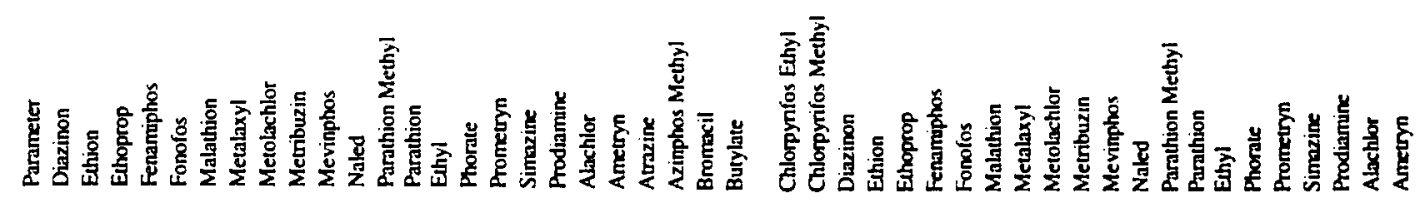
密

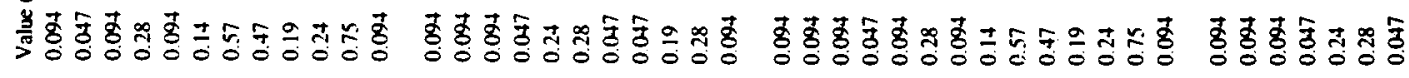

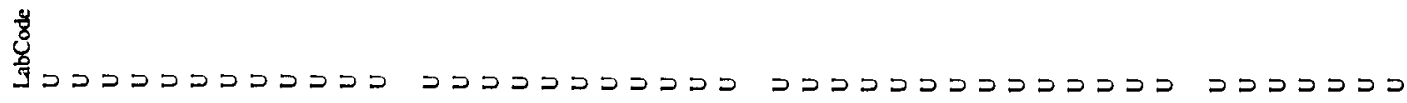

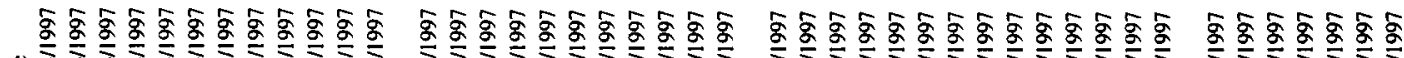

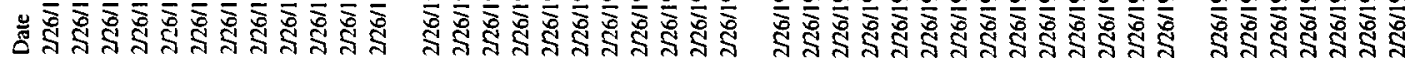

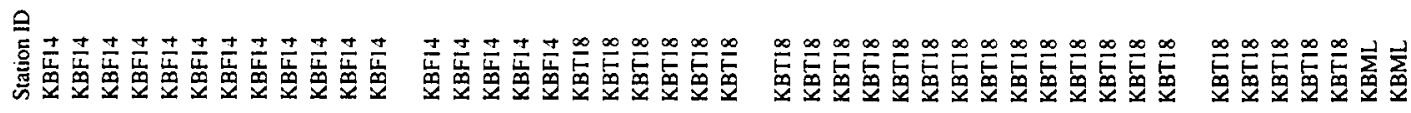

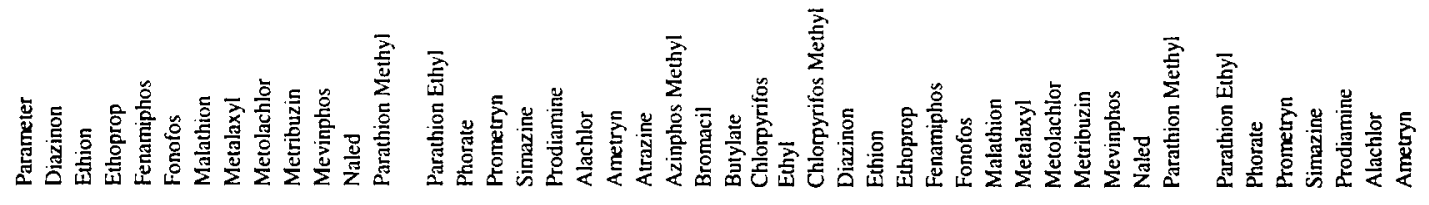

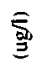

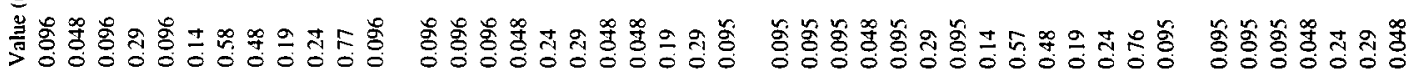
כ

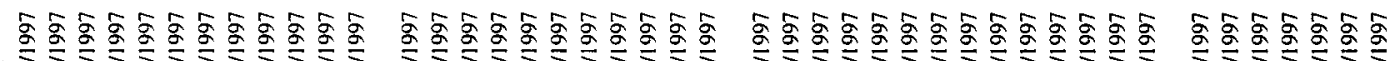

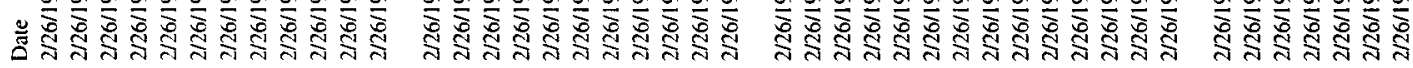

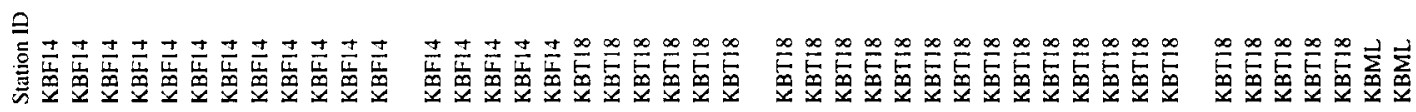




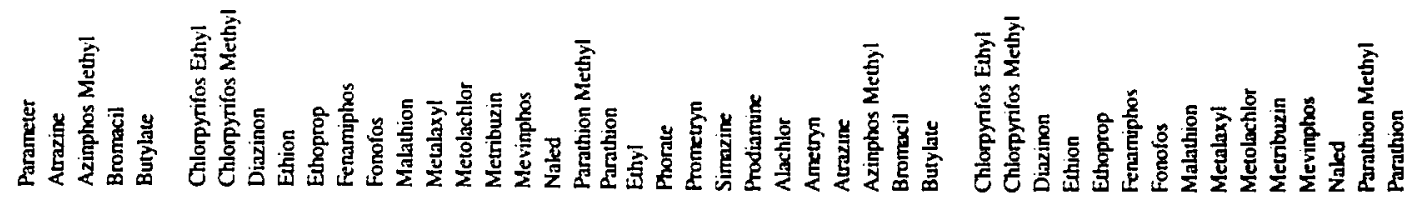

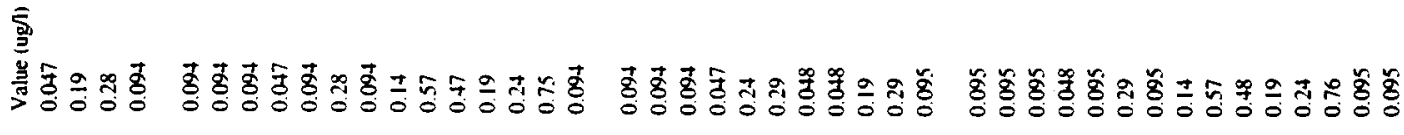

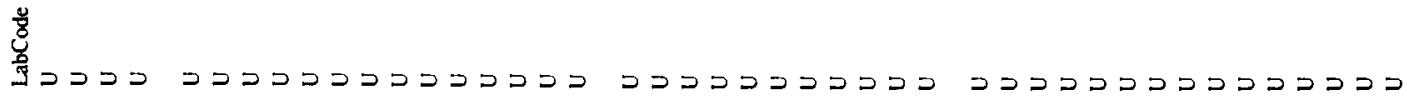

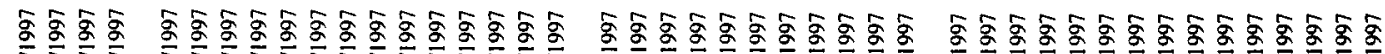

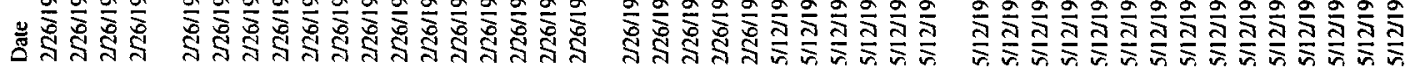

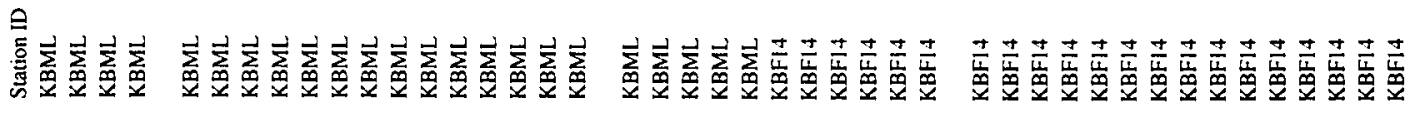

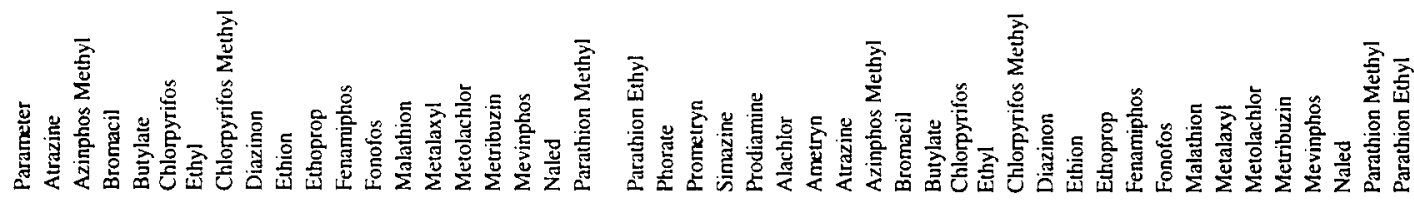
$\widehat{\underline{\mathrm{a}}}$

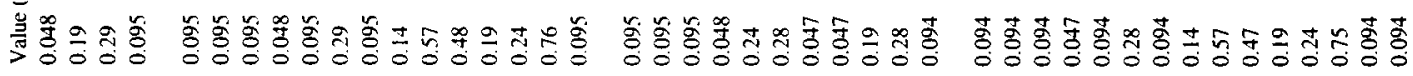
若

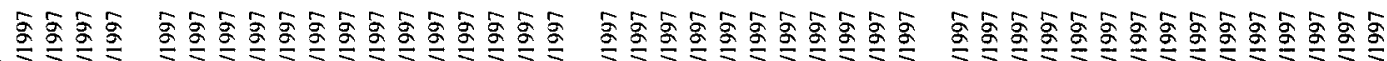

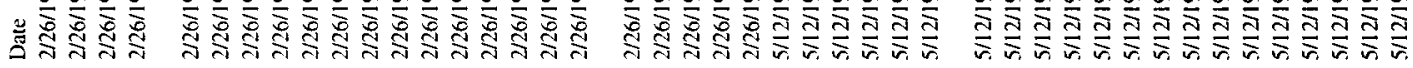

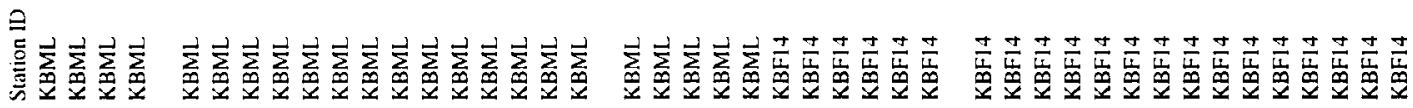




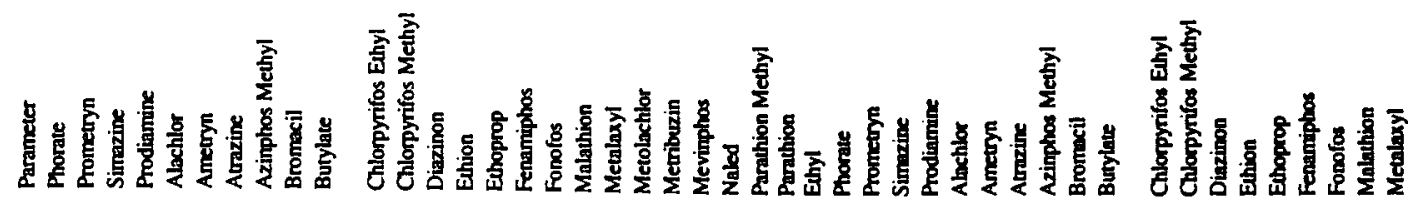
sing

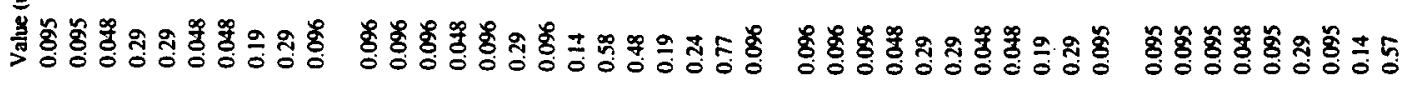

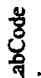
|

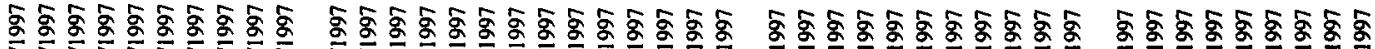

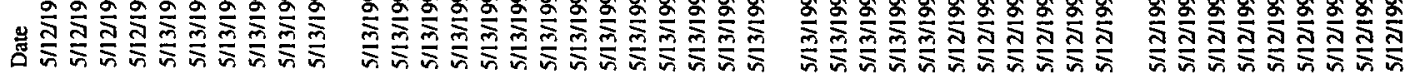

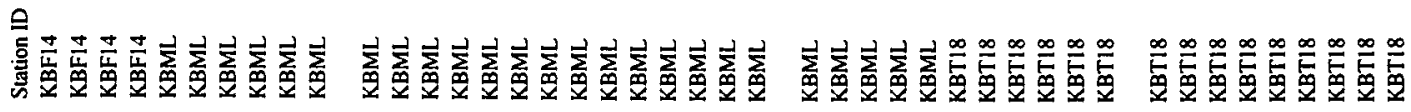

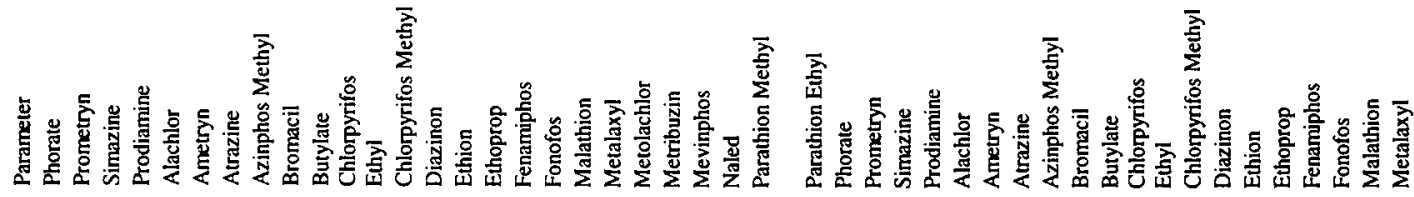
育

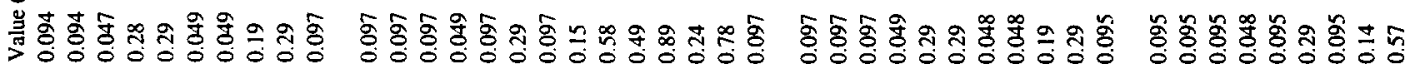
ষั

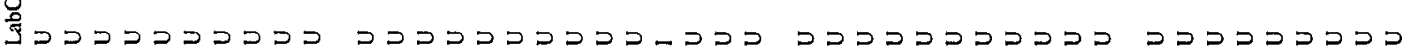

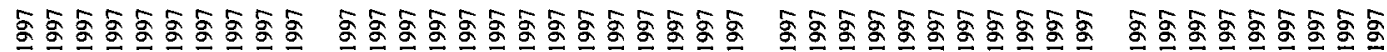

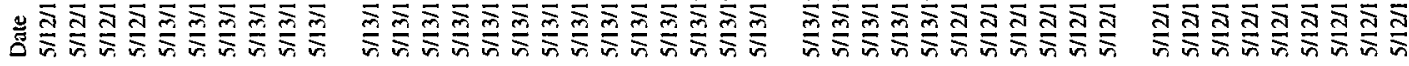

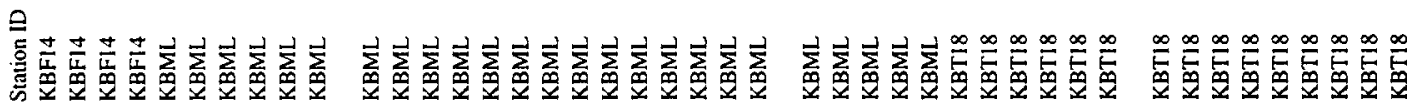




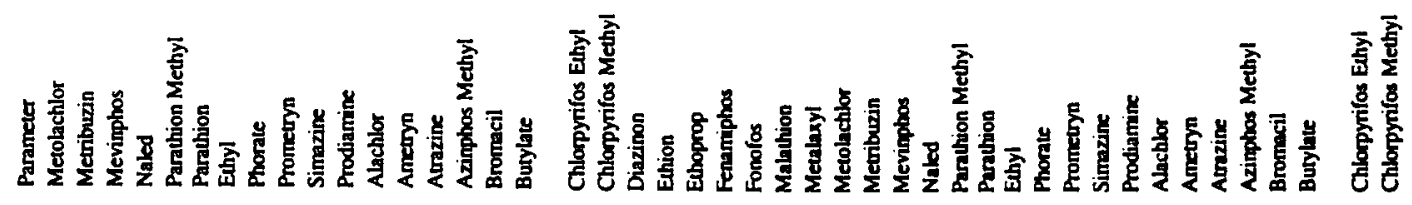

远

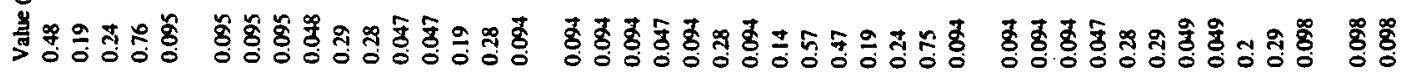

ชั

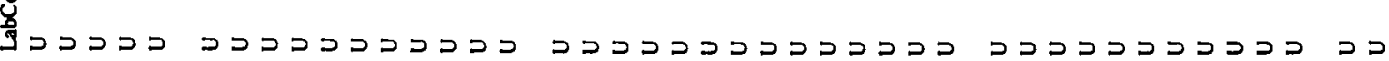

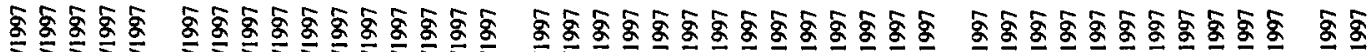

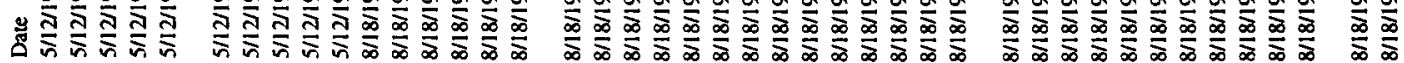

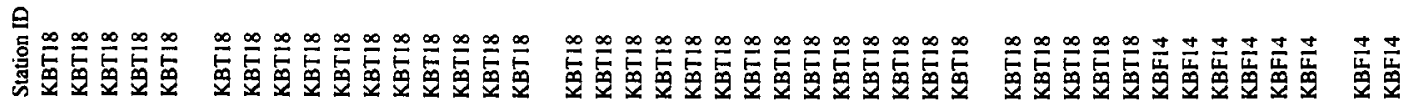

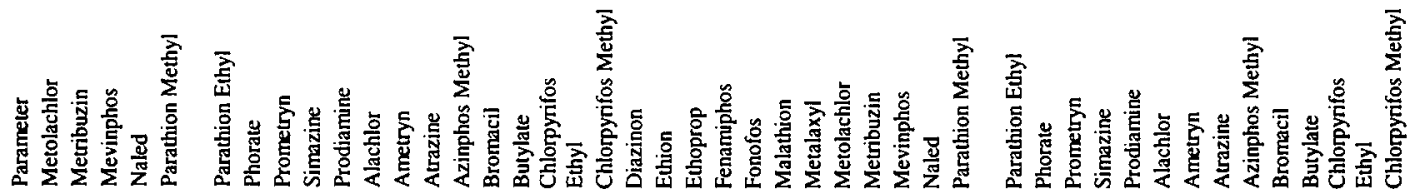

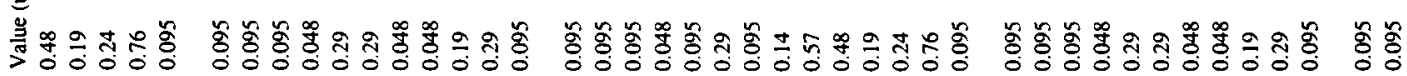

:

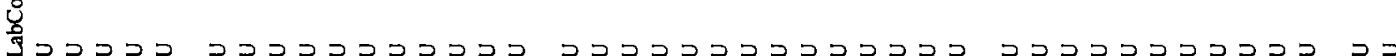

总点金金金

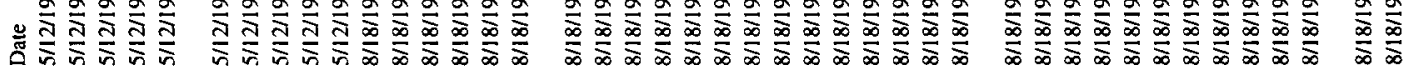

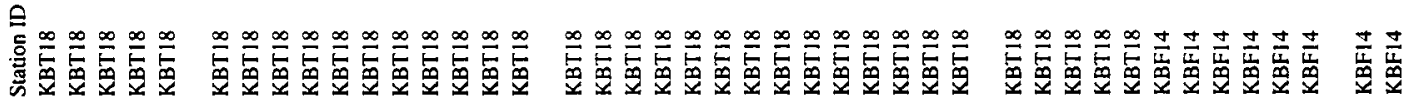




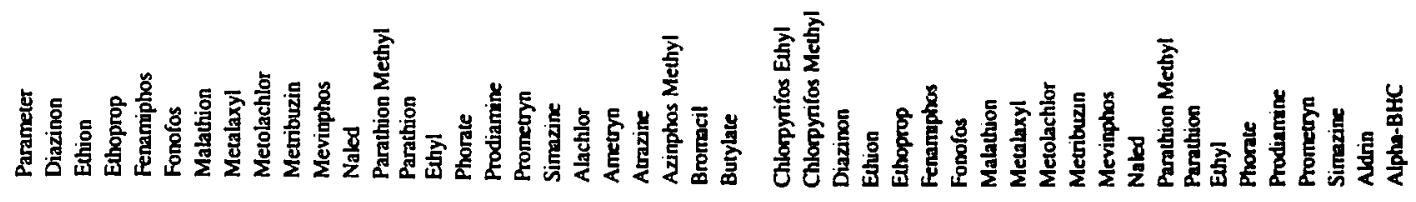

亭

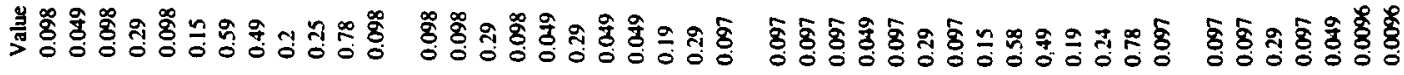

茟

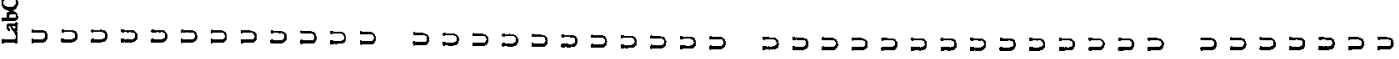

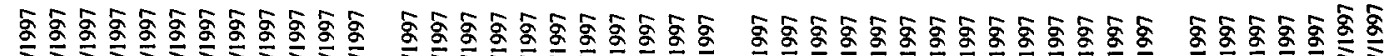

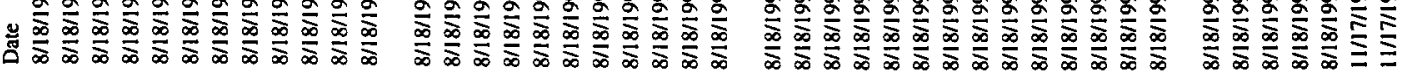

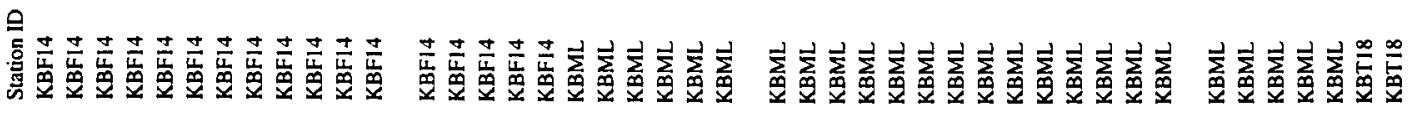

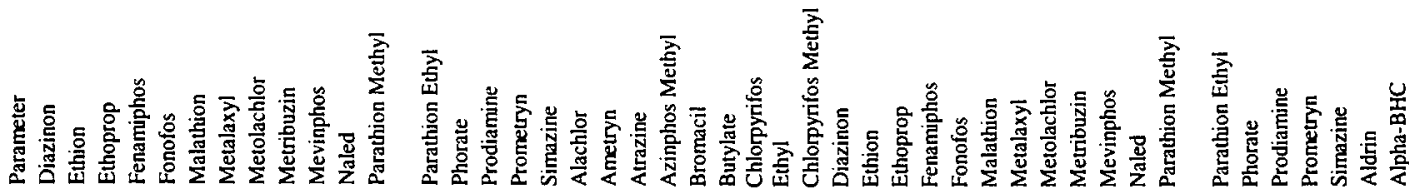
高

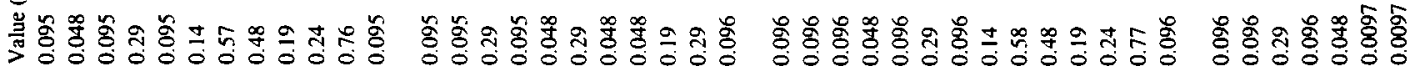

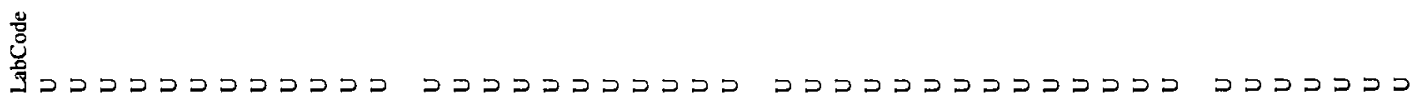

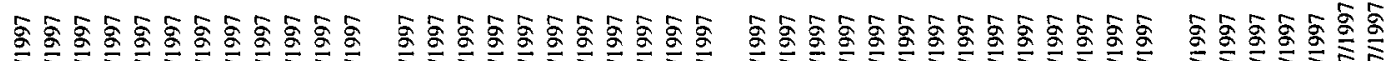

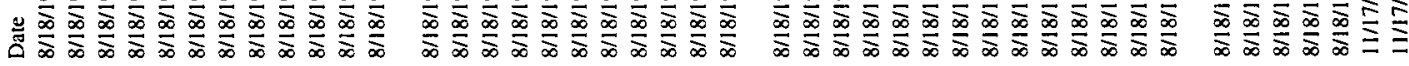

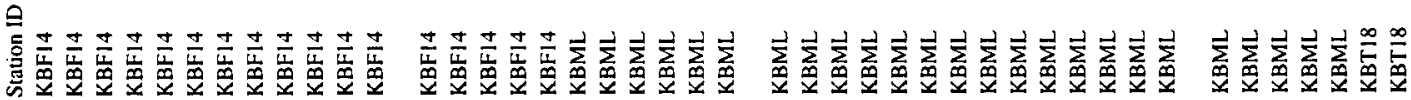




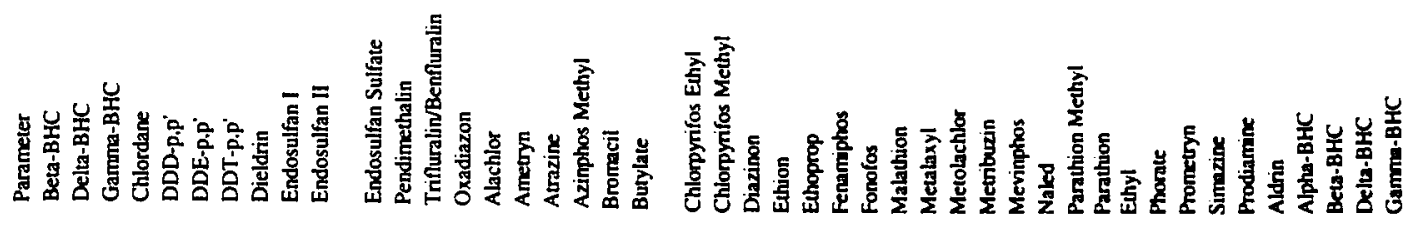

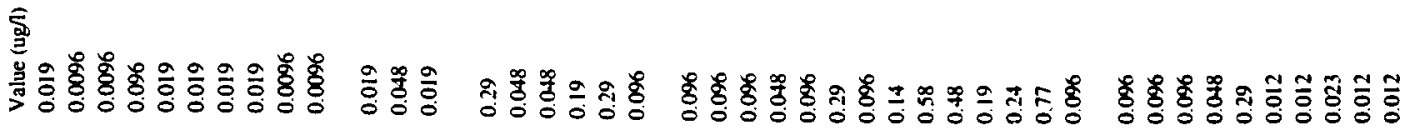

若

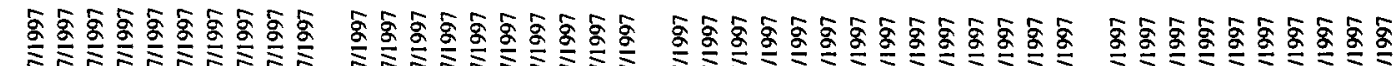

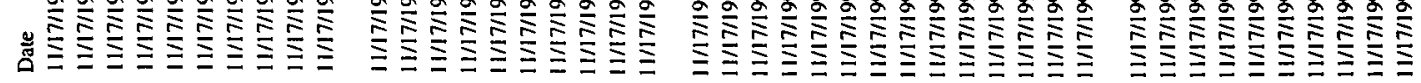

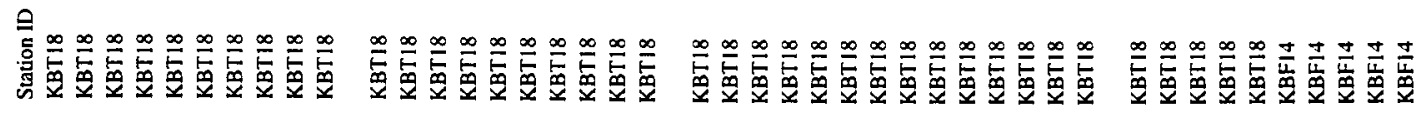

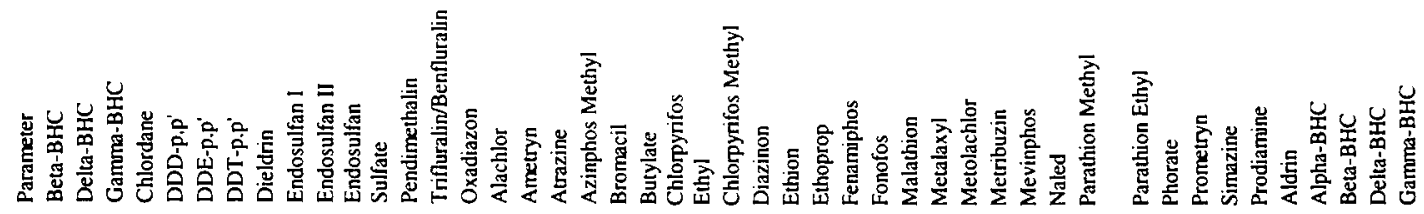
$\widehat{\widehat{\mathrm{d}}}$

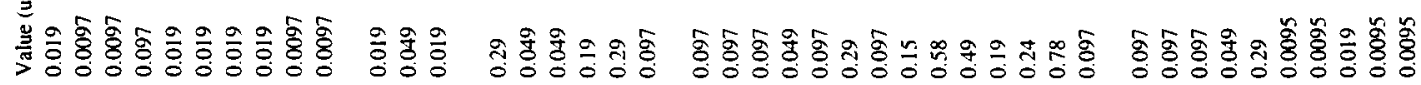

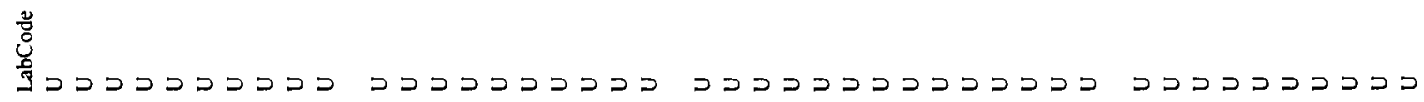

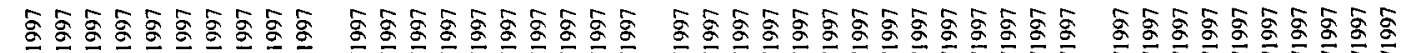

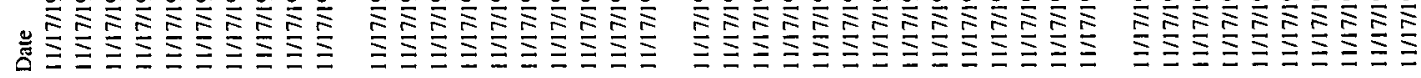

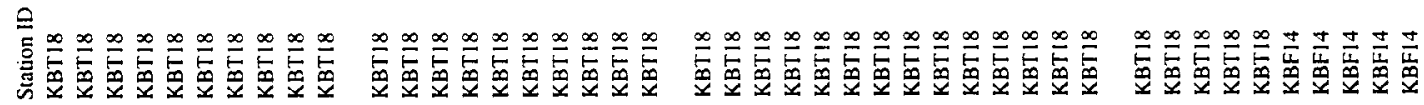




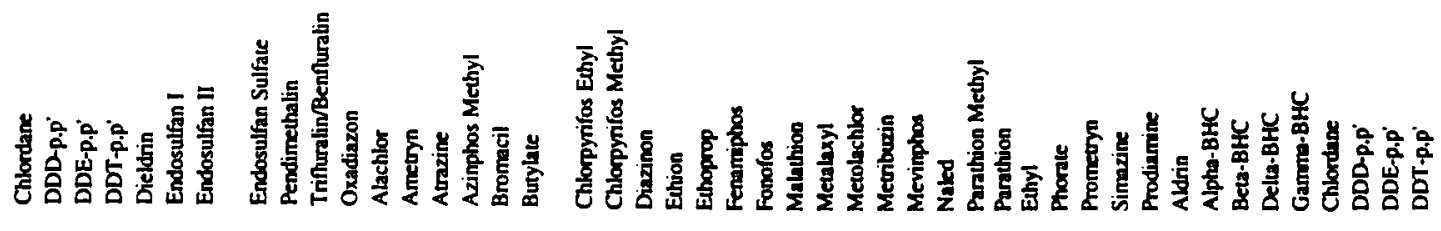

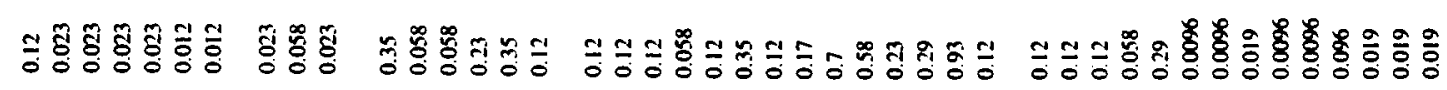

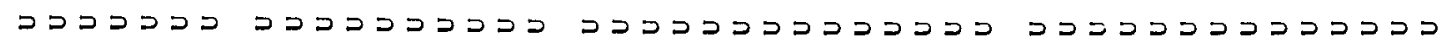

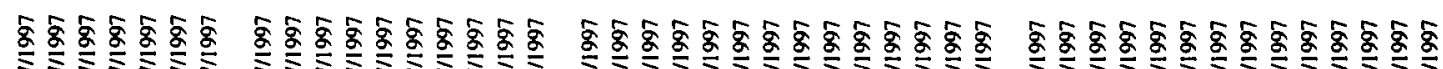

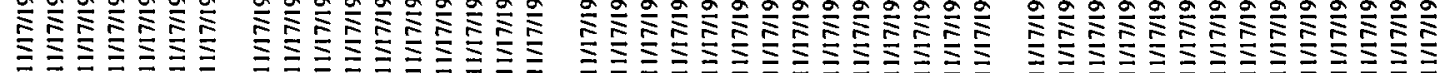

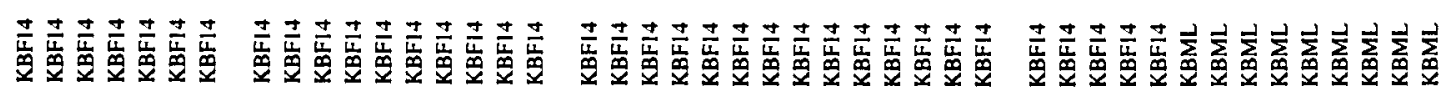

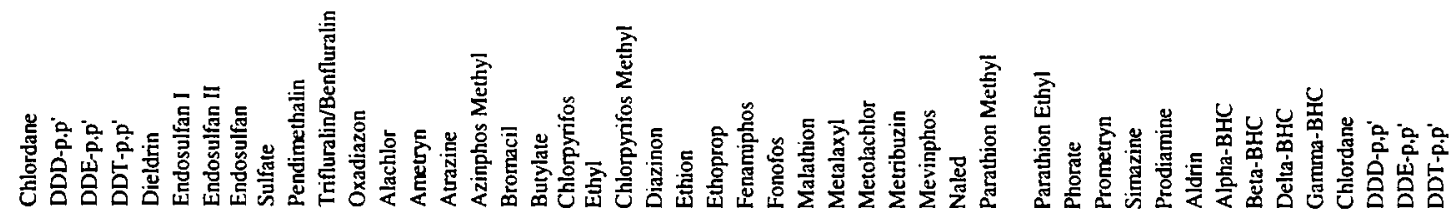

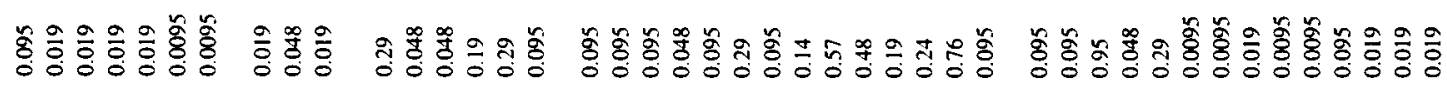

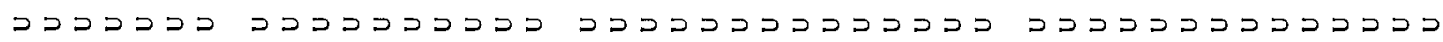

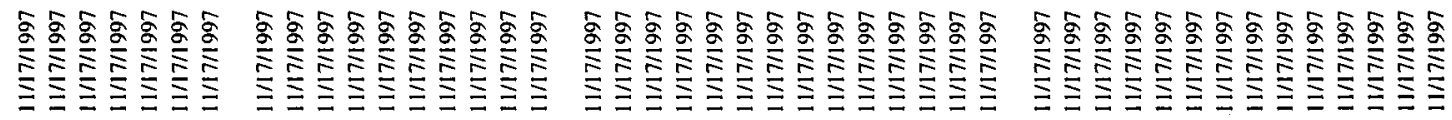

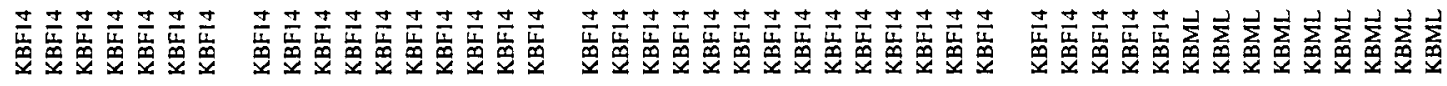


แIMแกแ

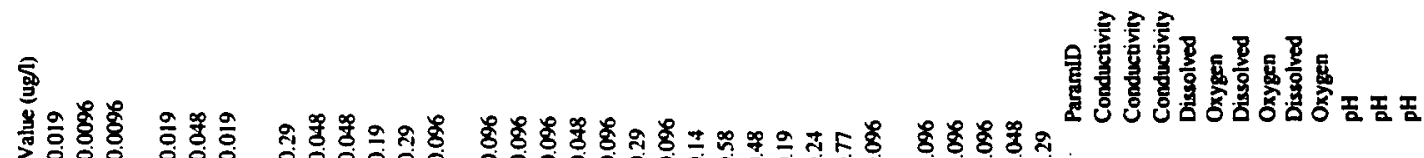

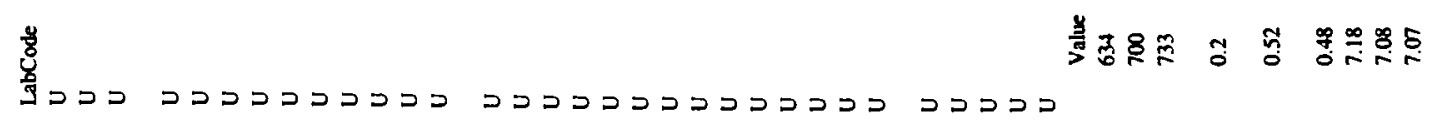

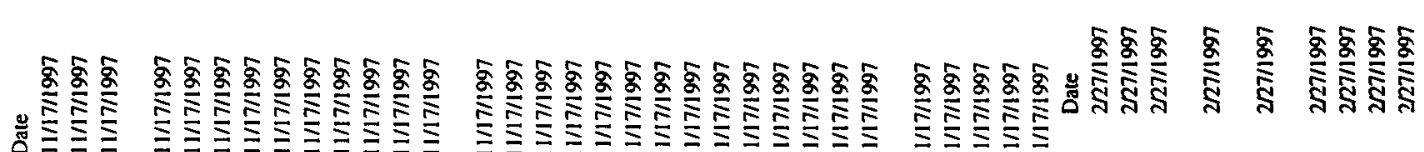

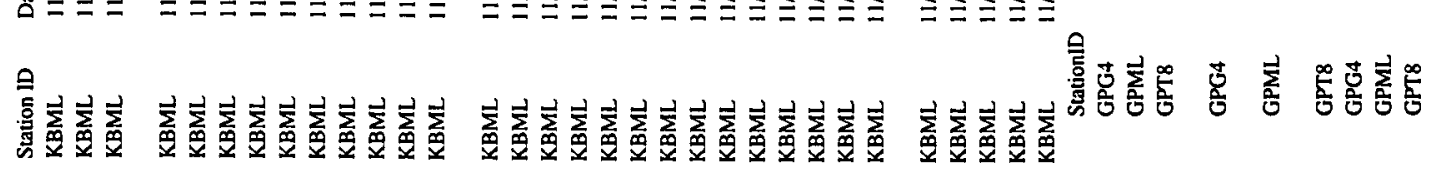

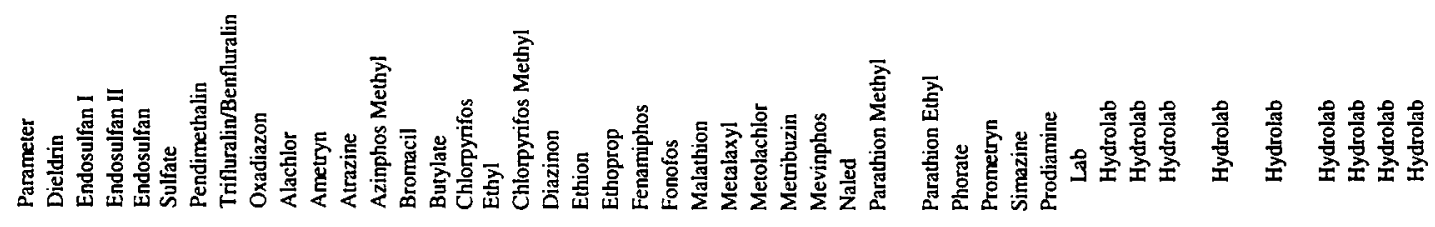

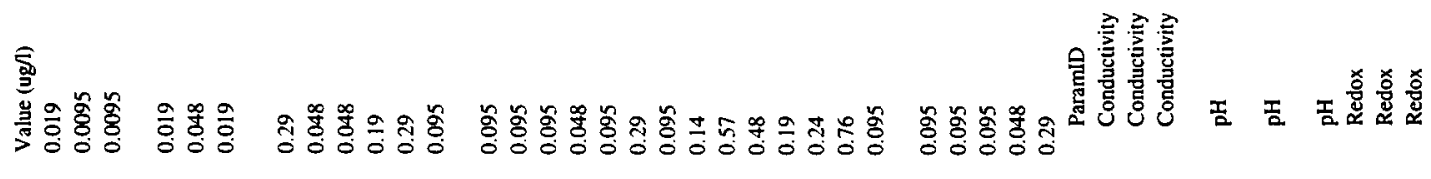

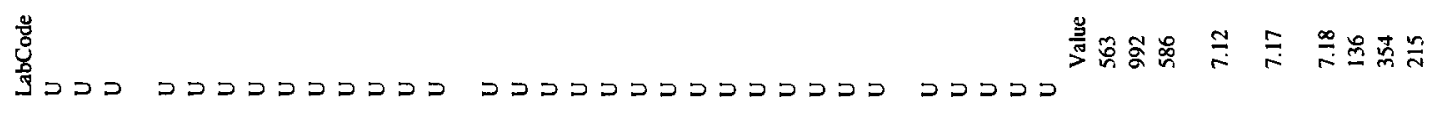
min mum

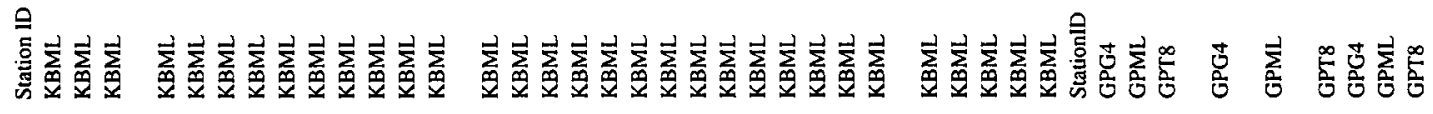




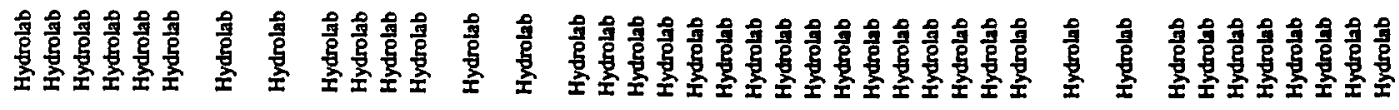

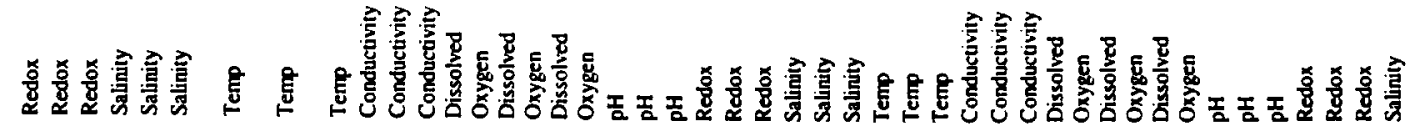

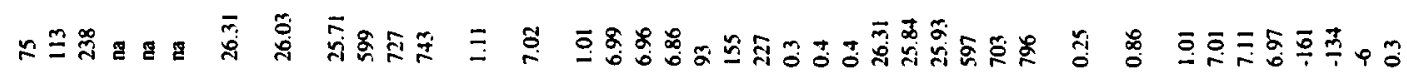

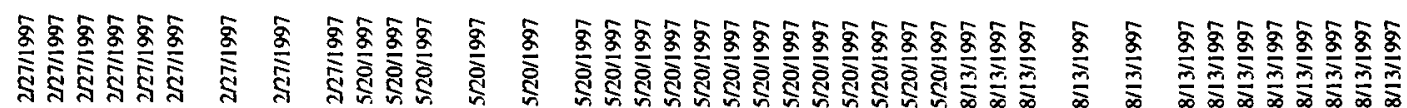

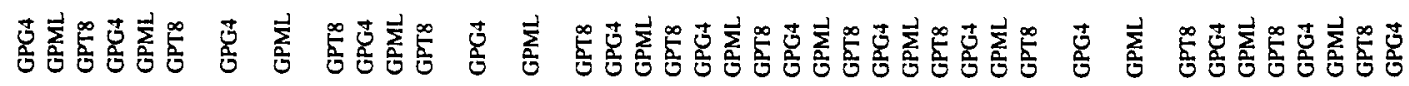

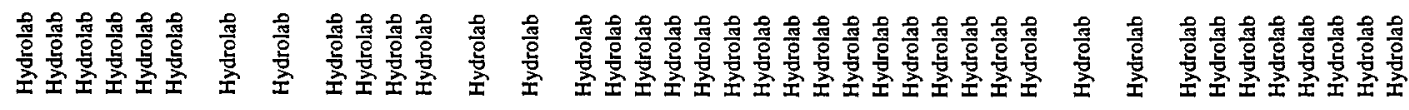

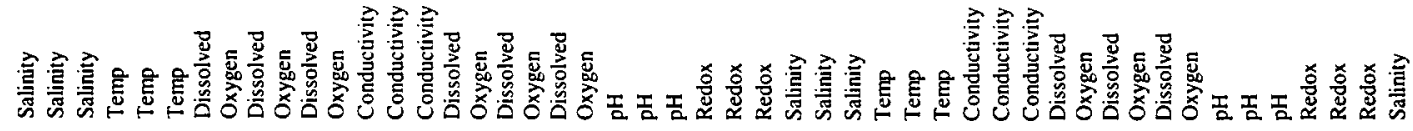

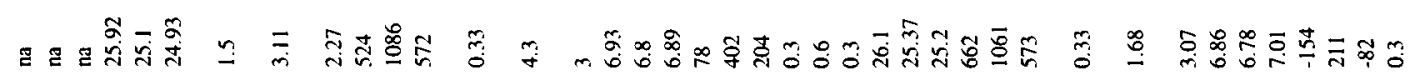

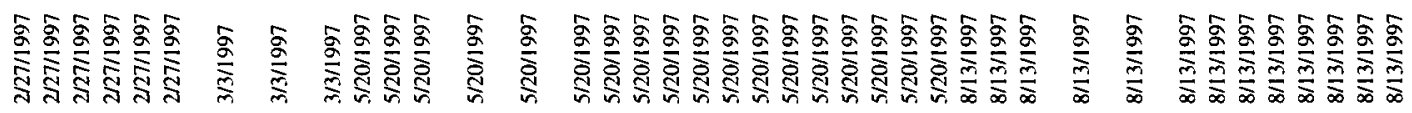

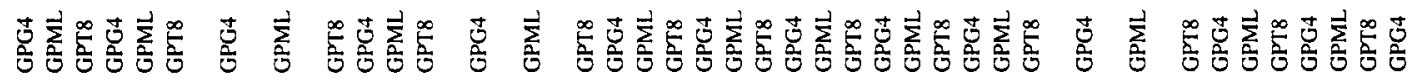




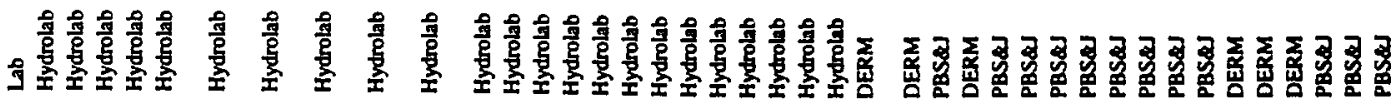

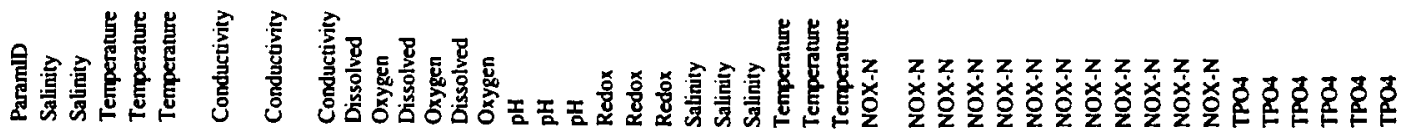

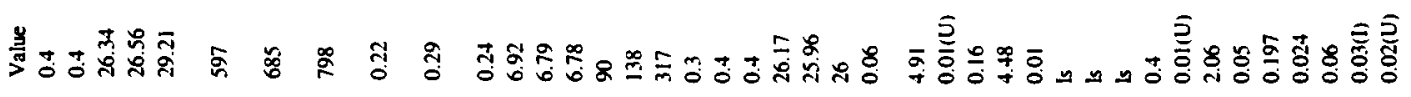

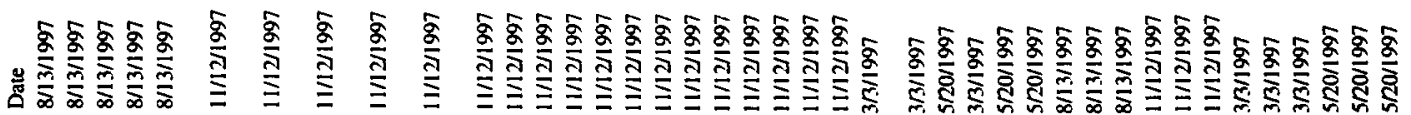

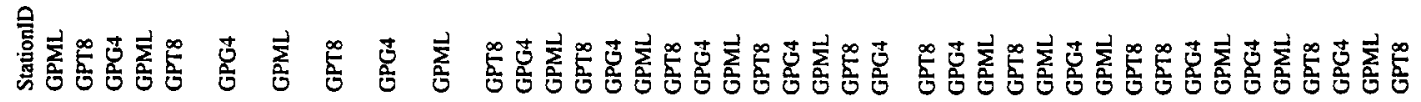

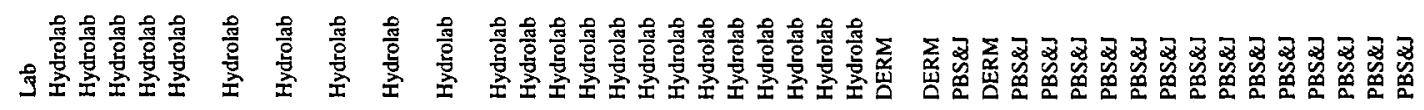

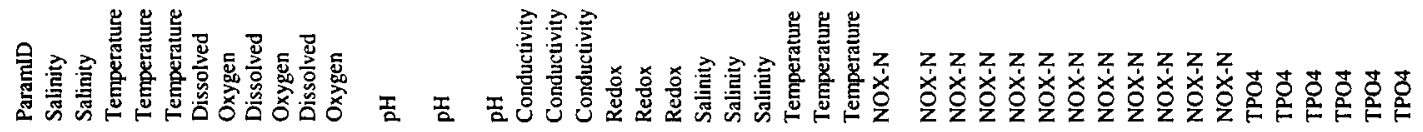

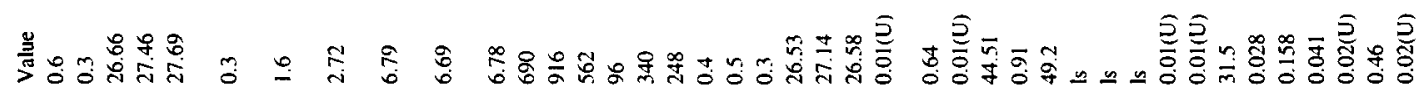

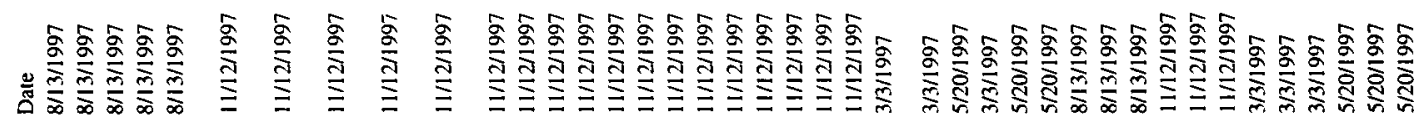

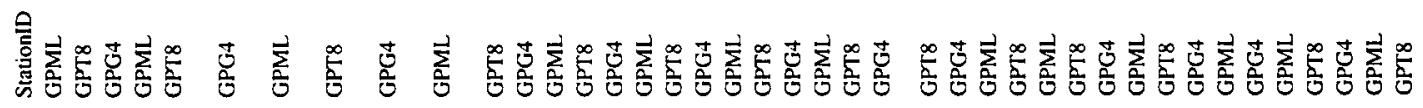




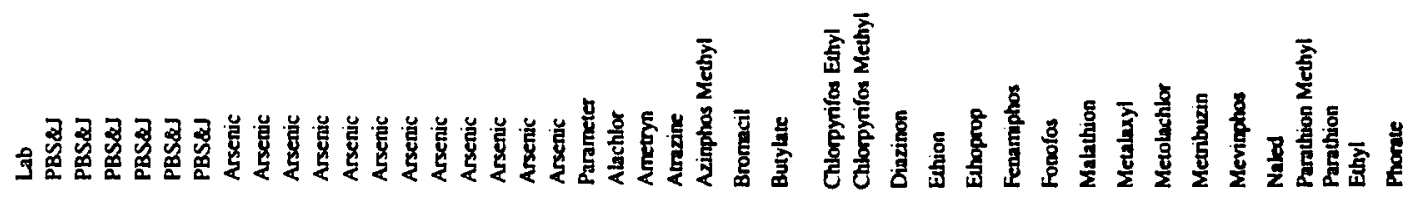

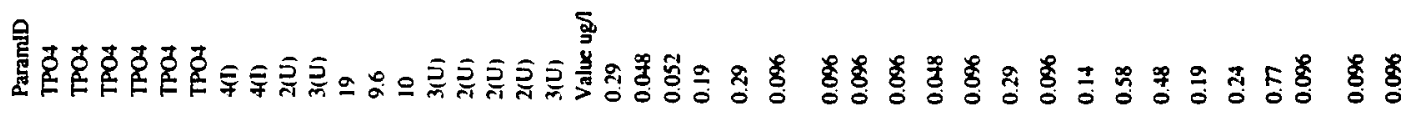

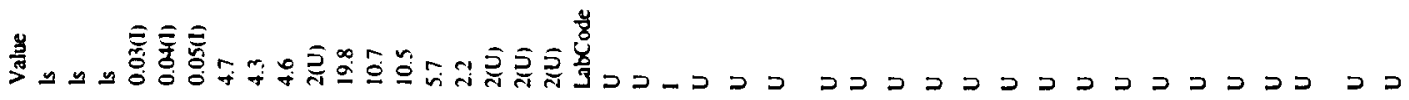

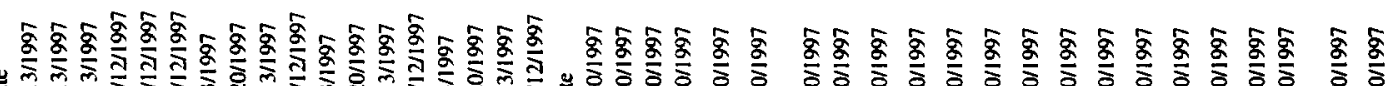

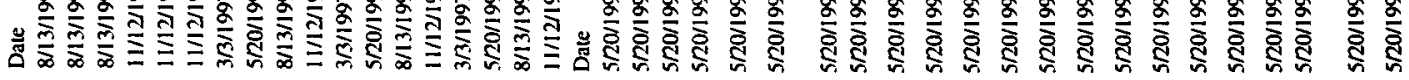

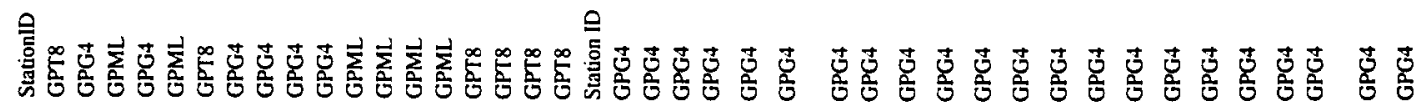

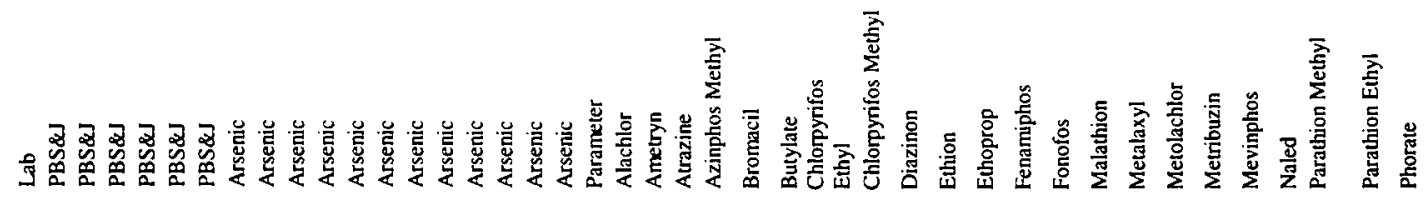

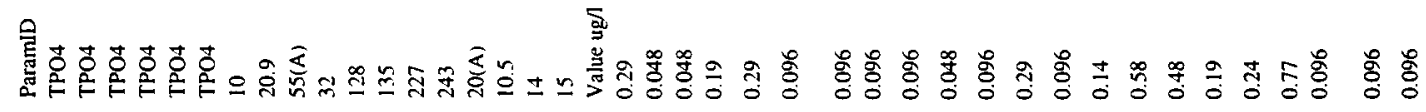

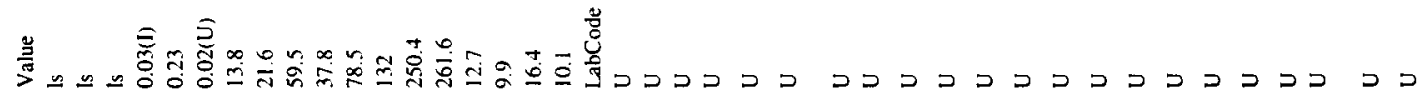

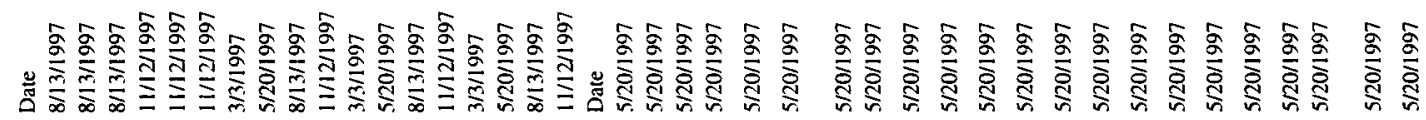

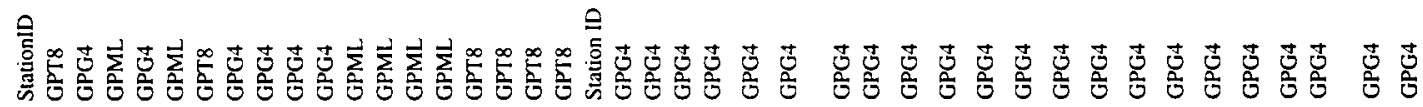




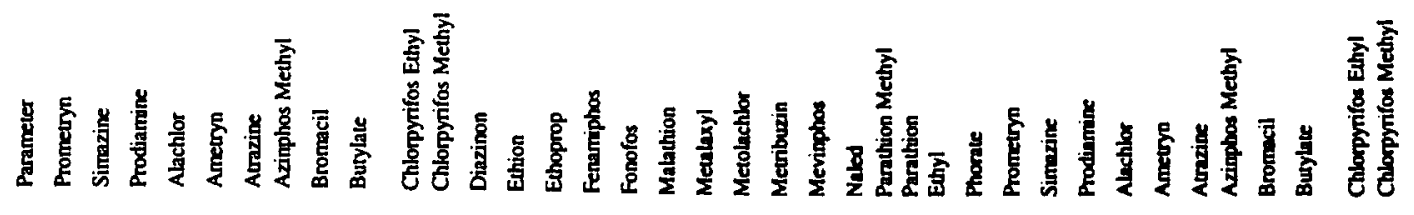

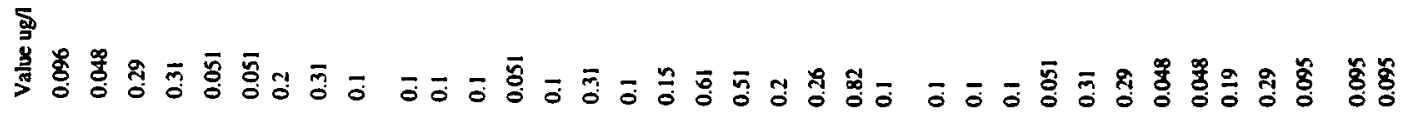

苟

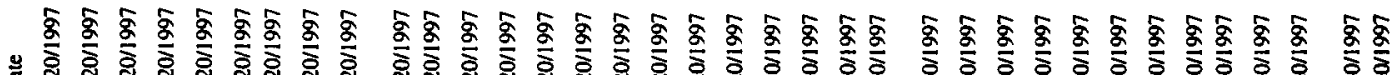

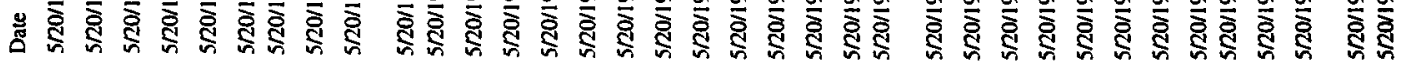

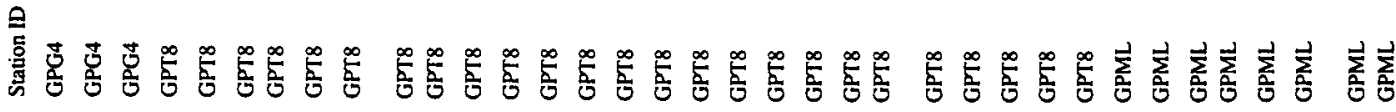

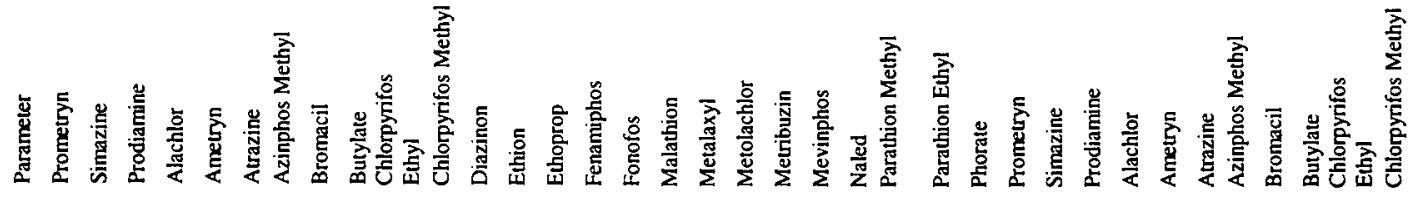

品

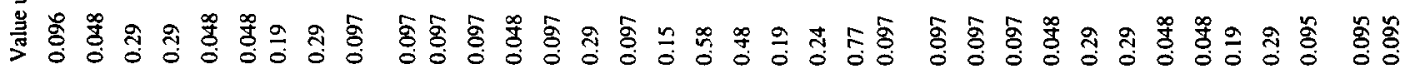

兑

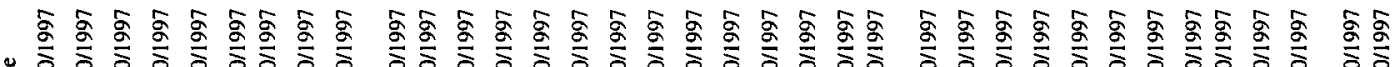

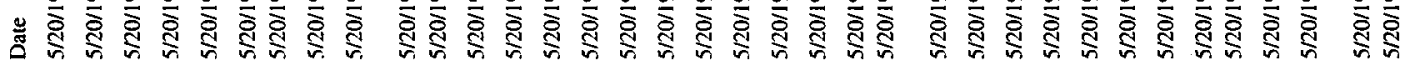

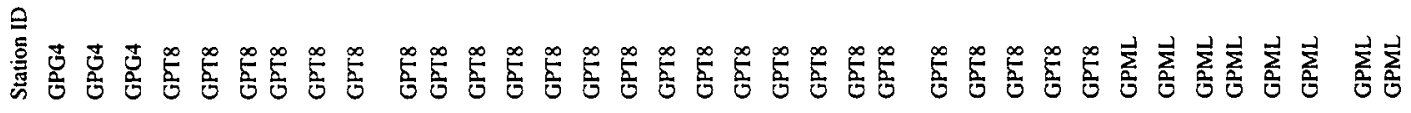




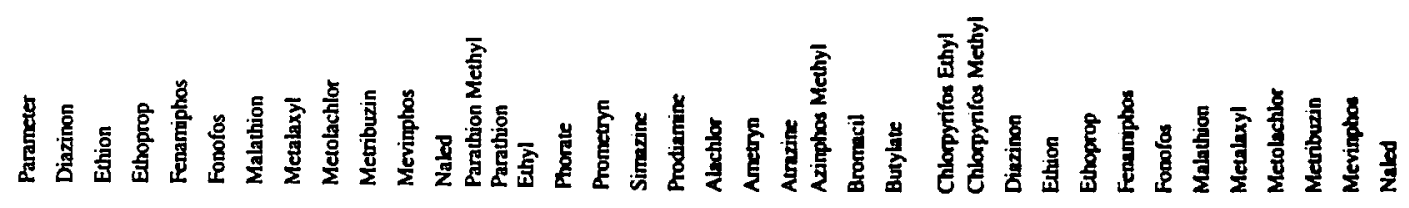

녹ำ V)

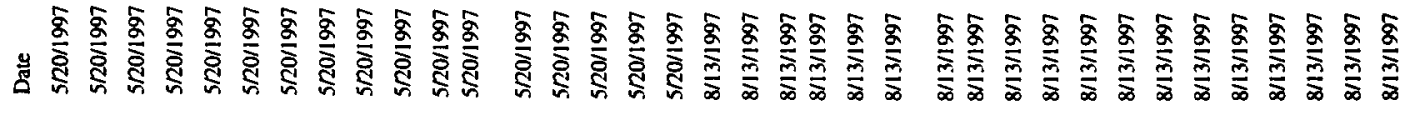

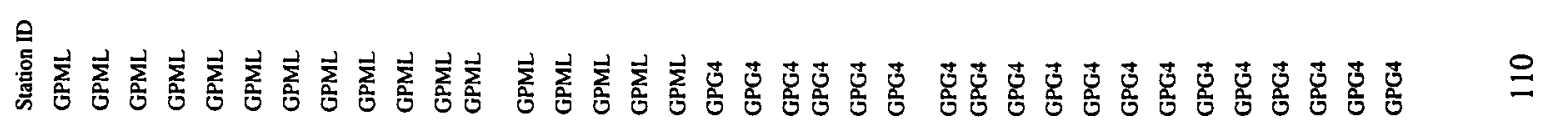

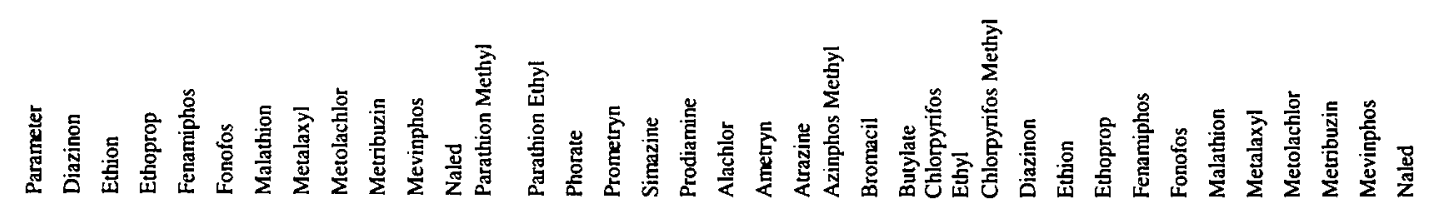

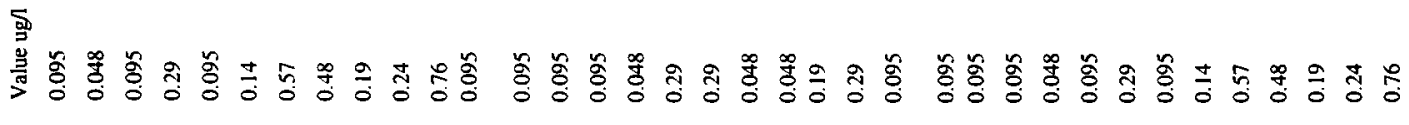

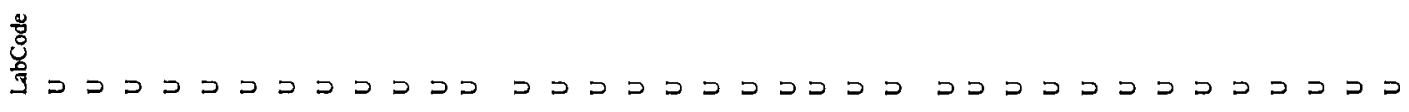

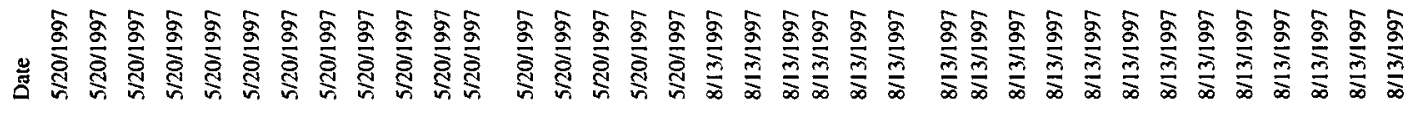

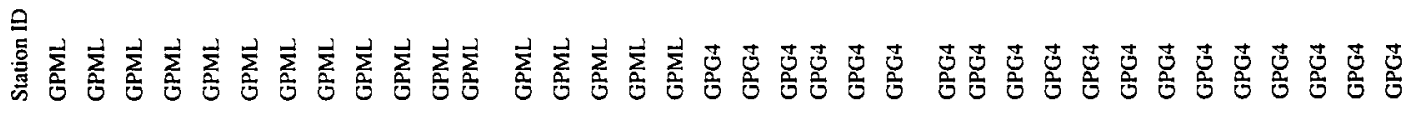




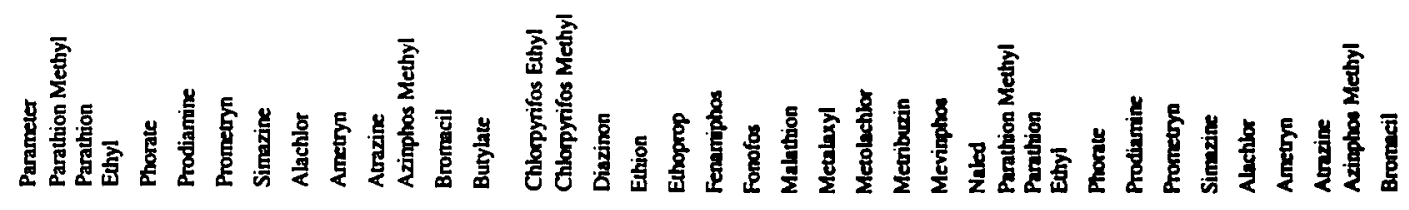

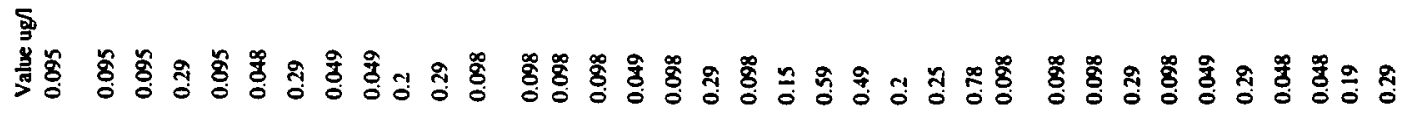

绻

ง

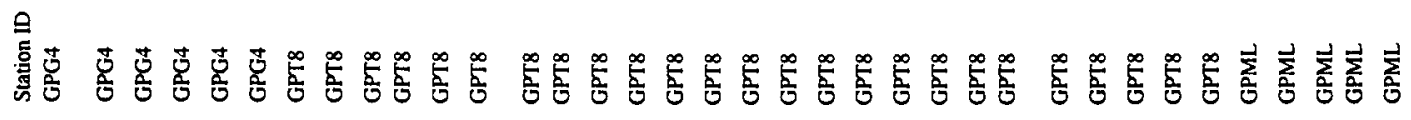

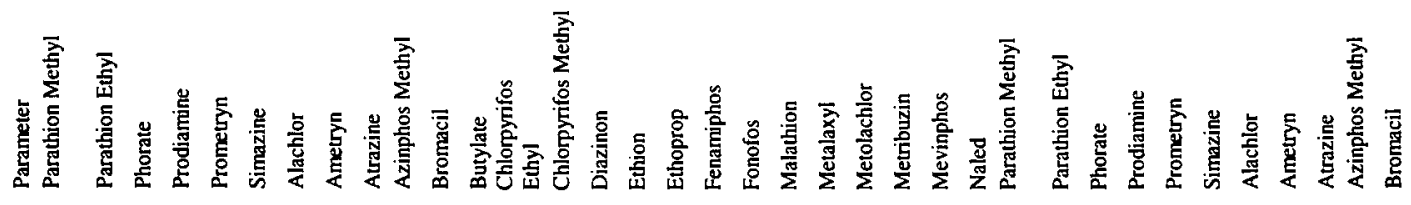

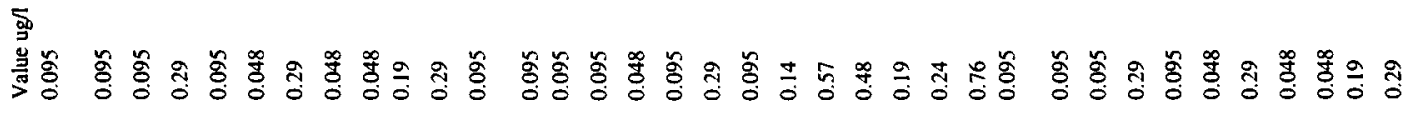

V)

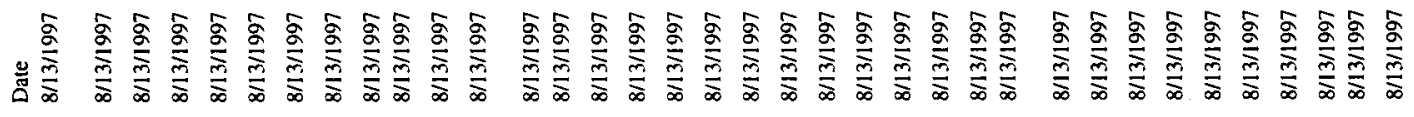

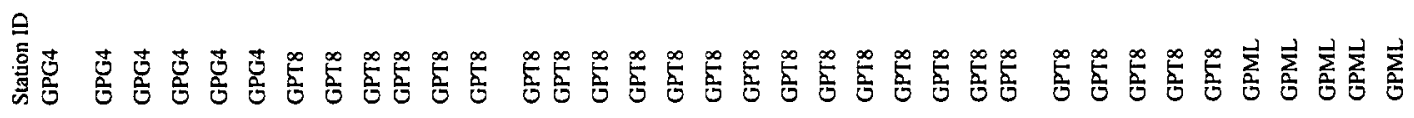




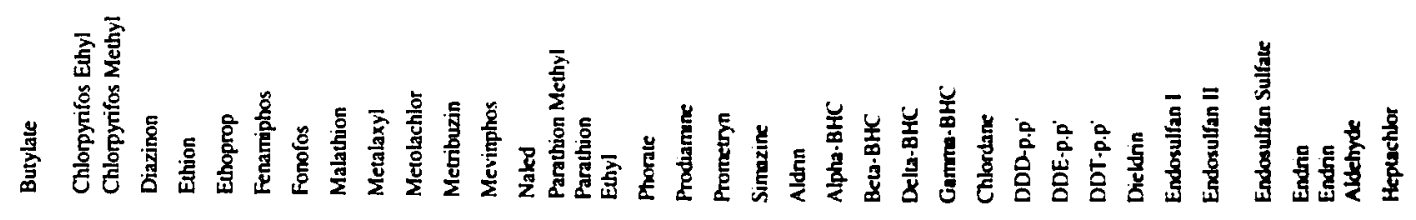

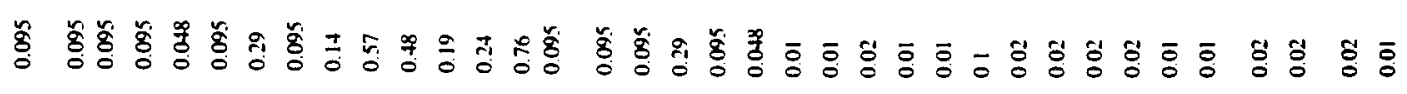

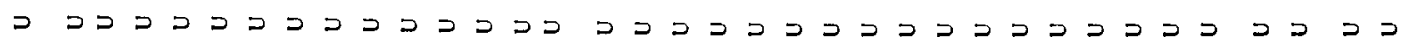

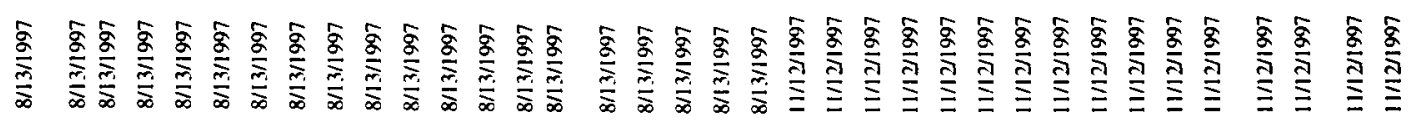

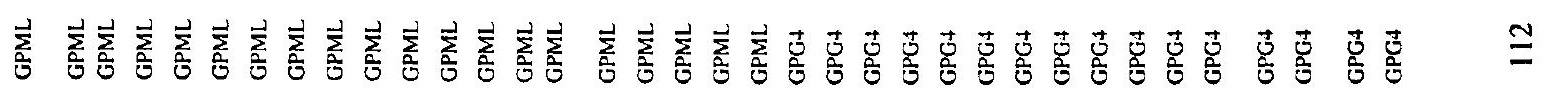

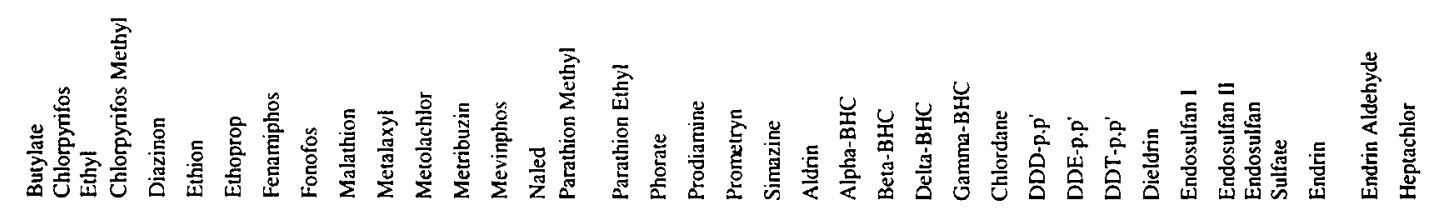

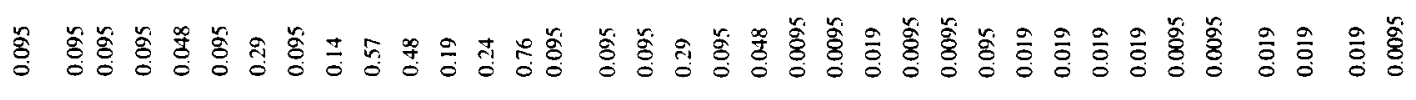

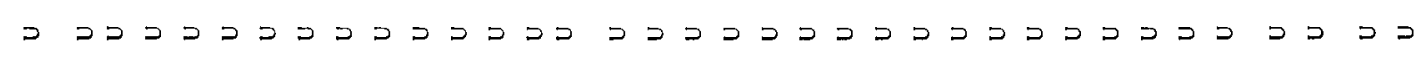

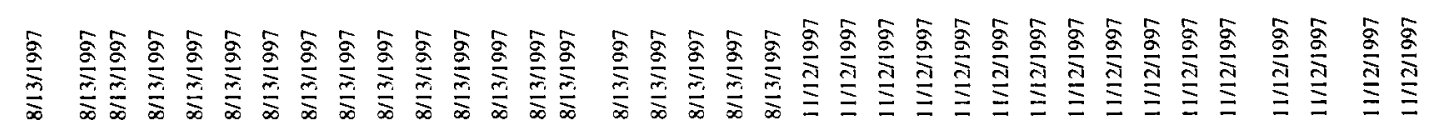

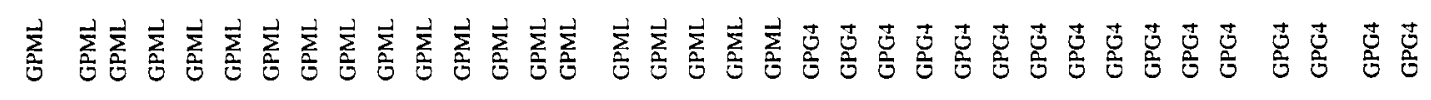




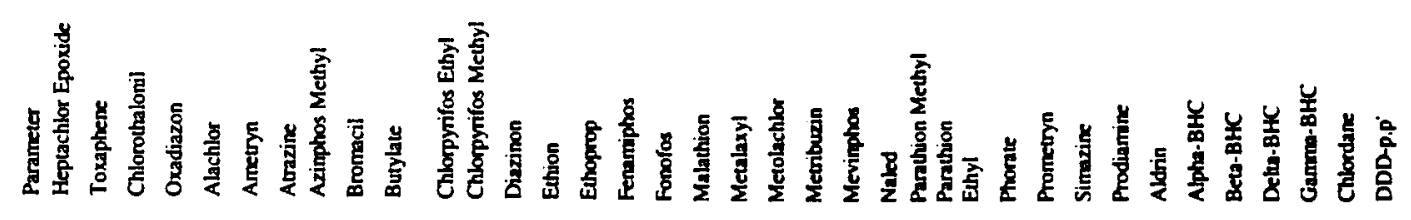

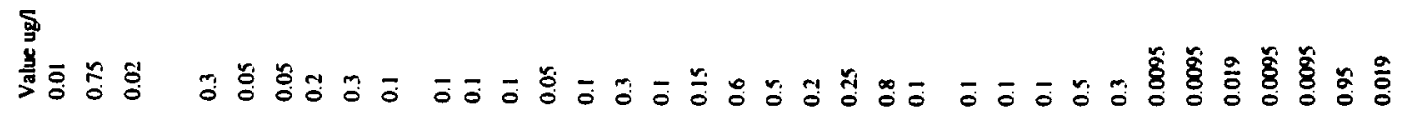
隹

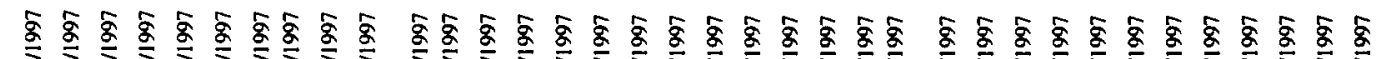

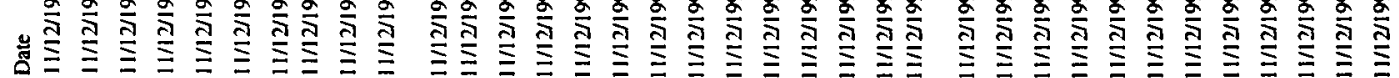

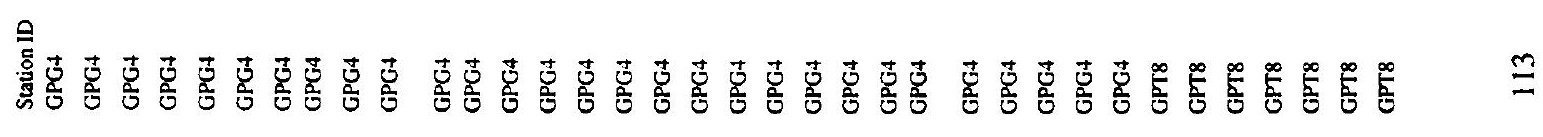

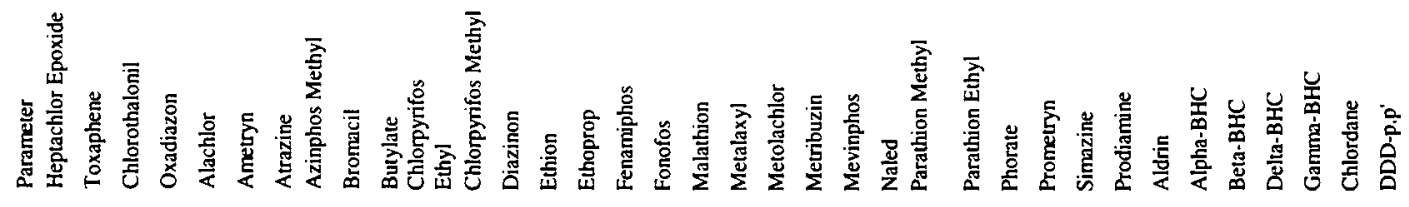

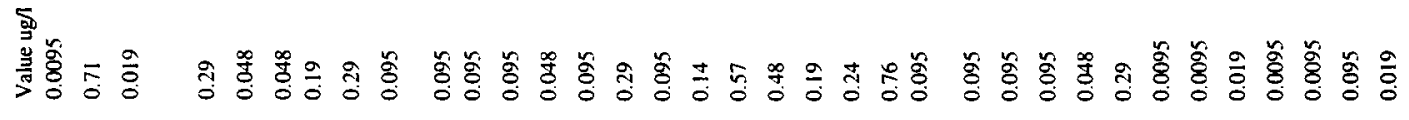

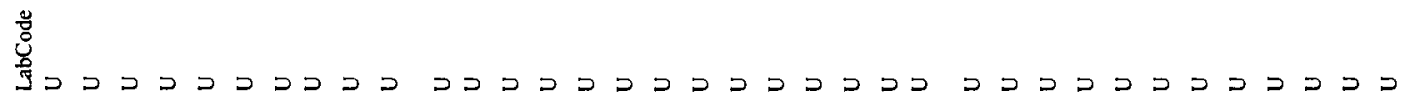

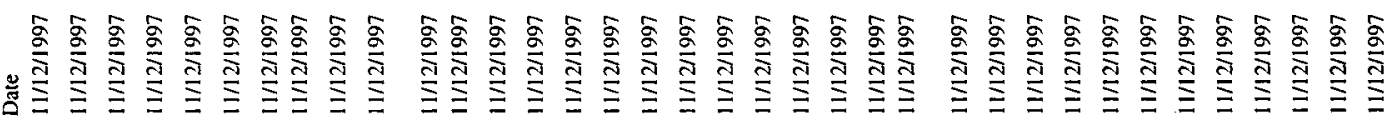

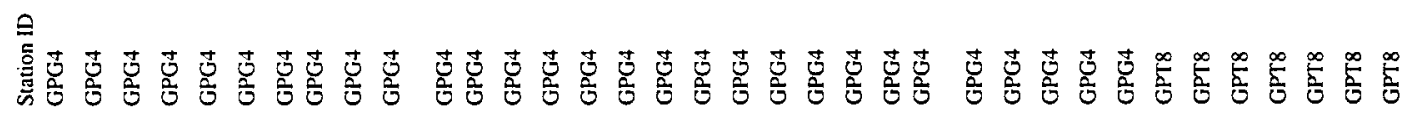




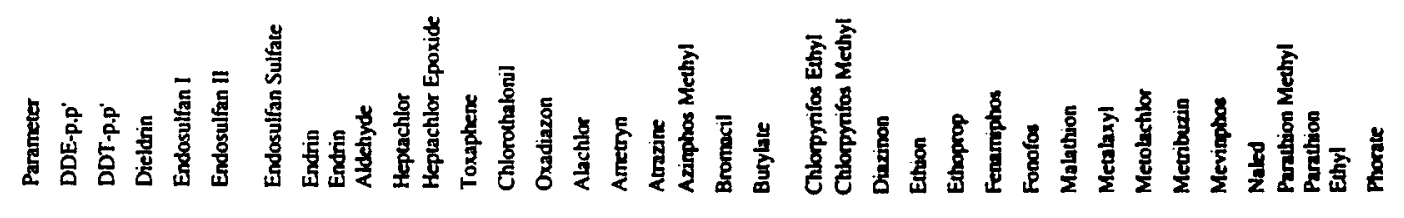

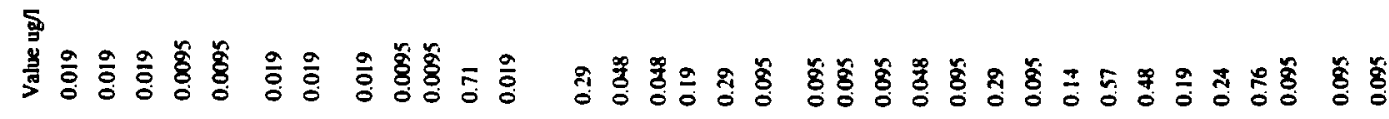

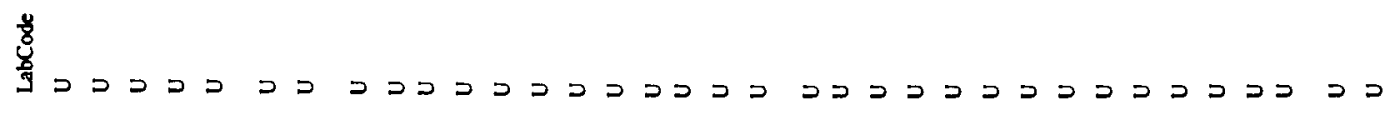

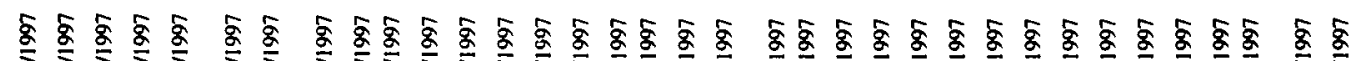

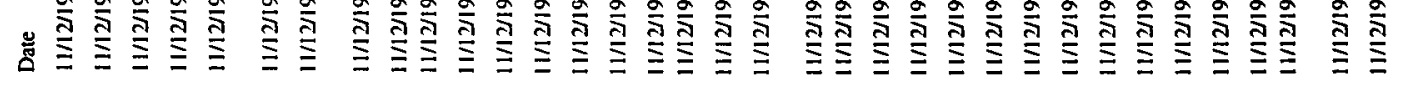

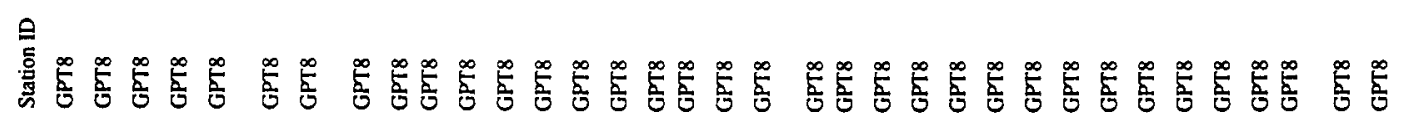

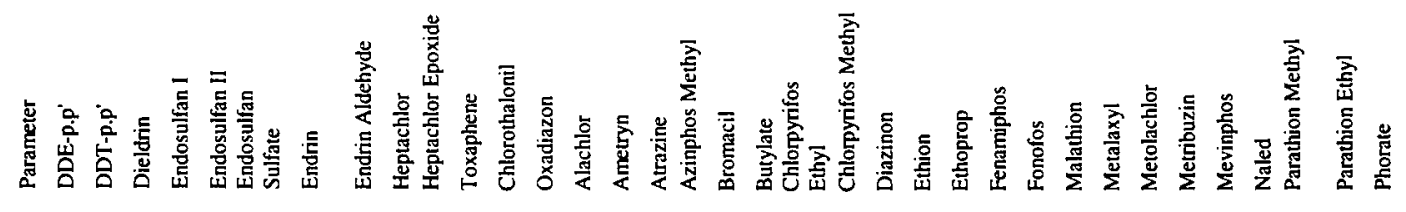

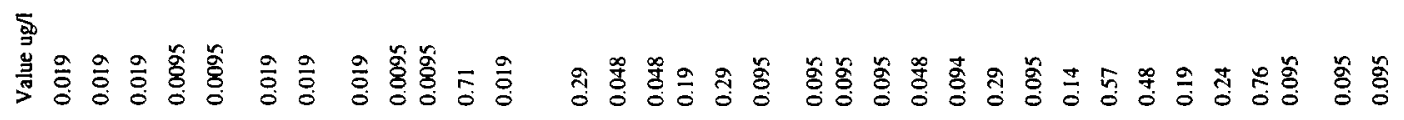

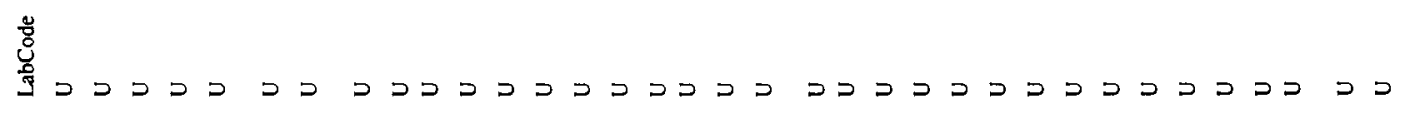

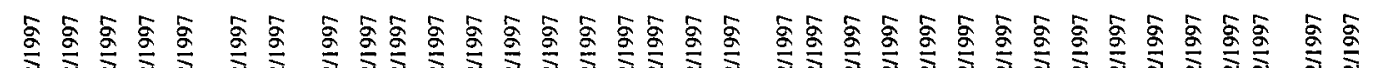

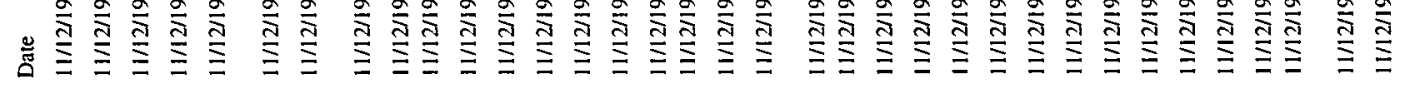

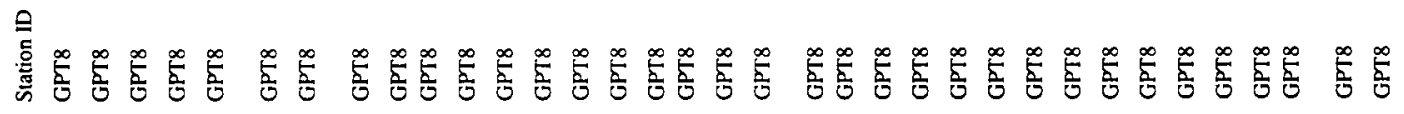




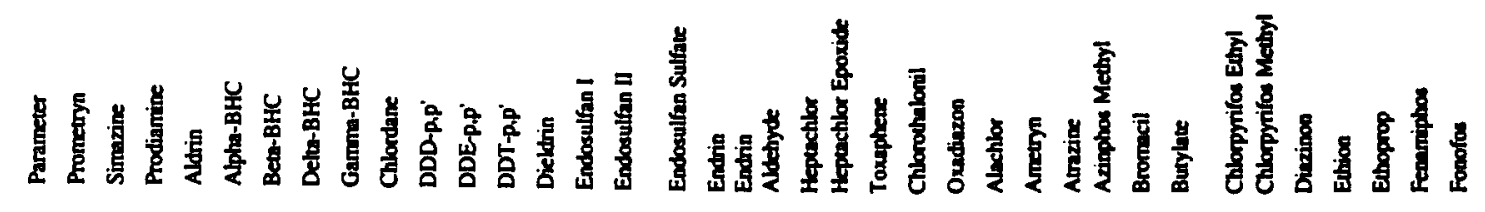

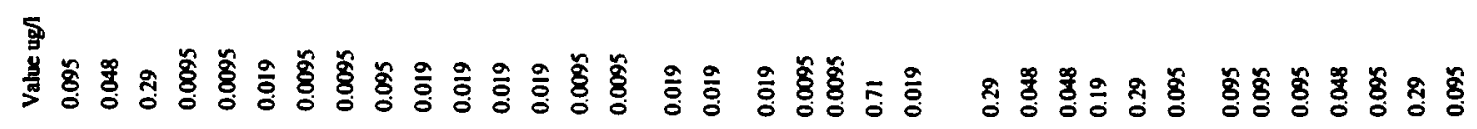

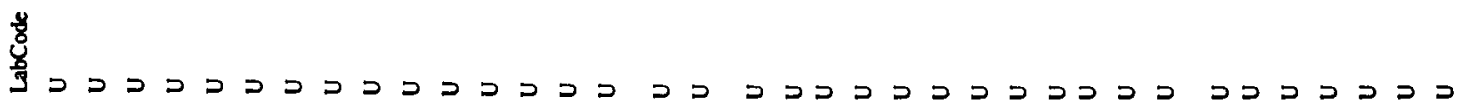

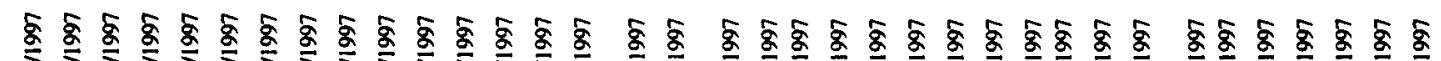

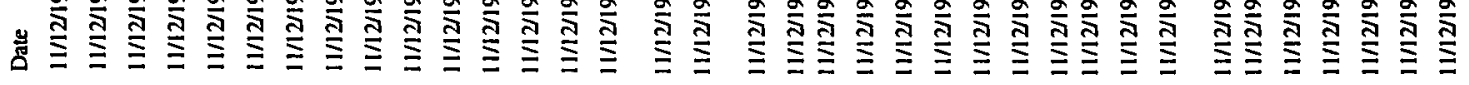

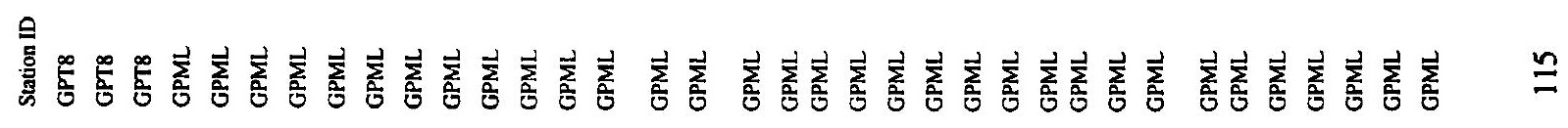

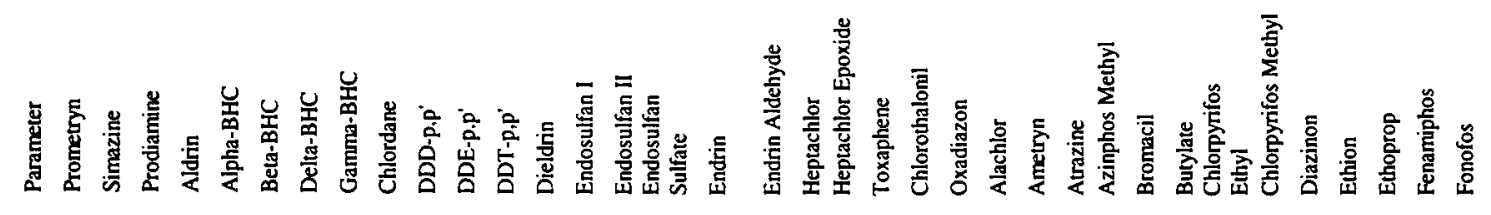

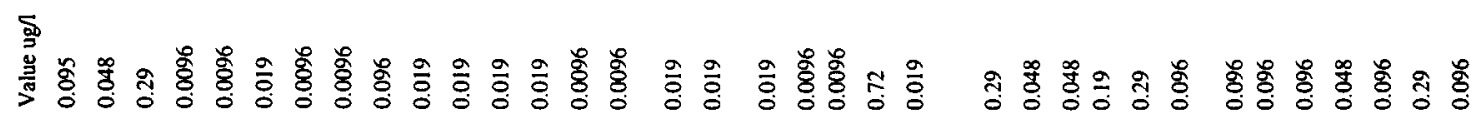
B.

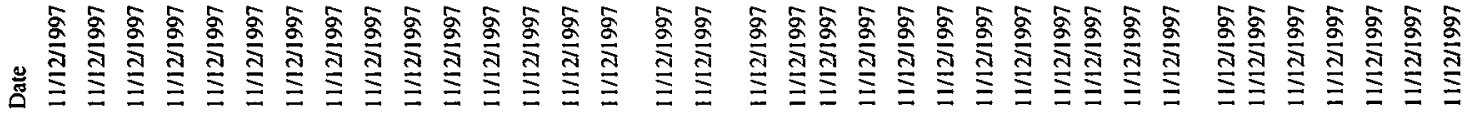

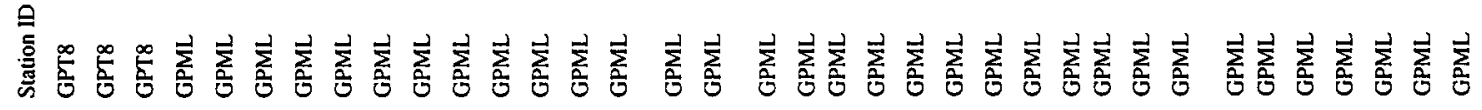


MIn!m!n

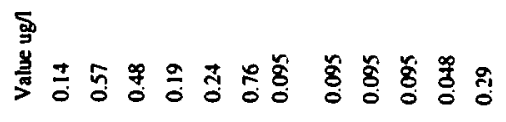

$\frac{y}{8}$
है
$\frac{y}{3}$

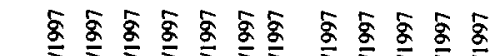

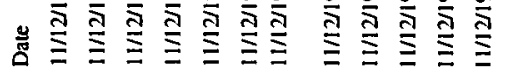

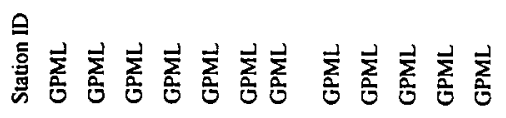

InIIInII

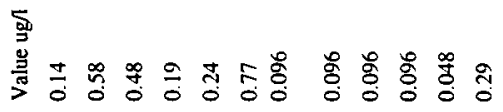

若

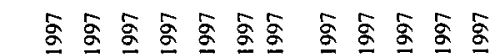

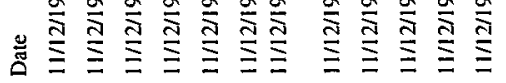

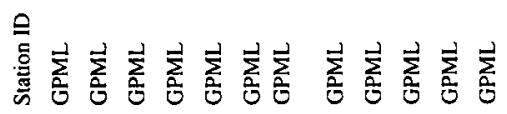




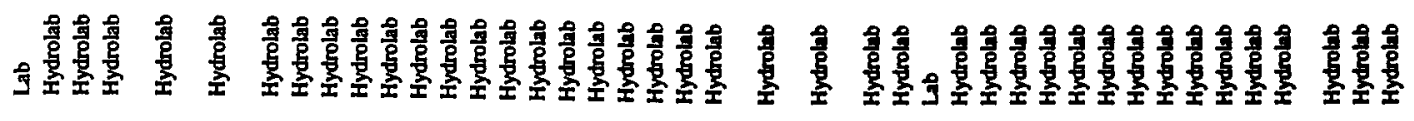

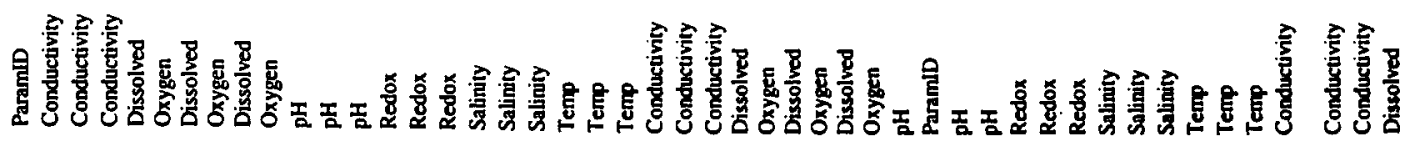

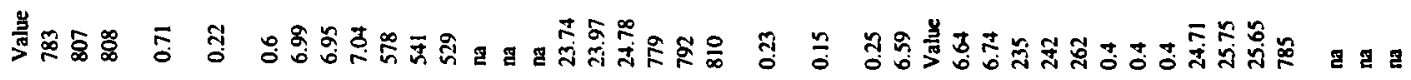

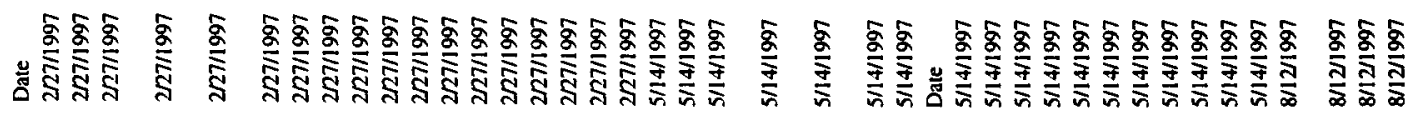

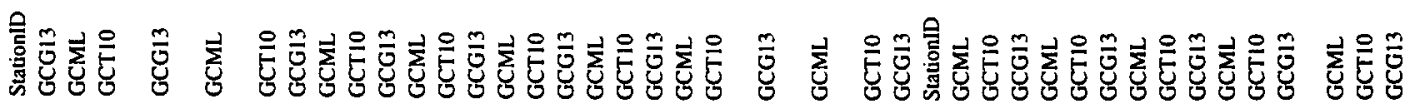

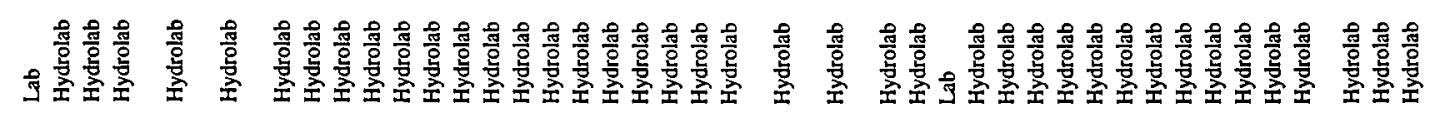

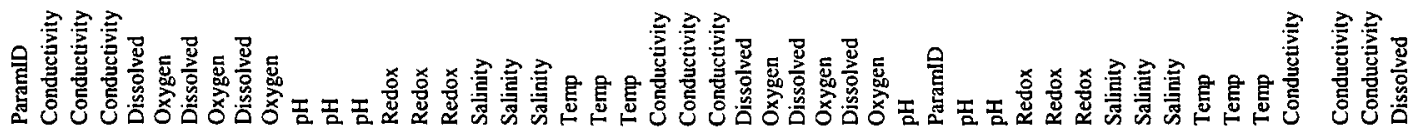

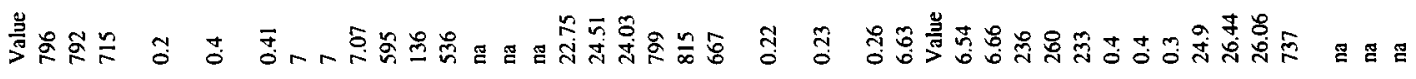

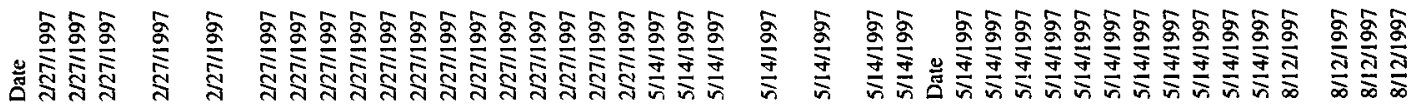

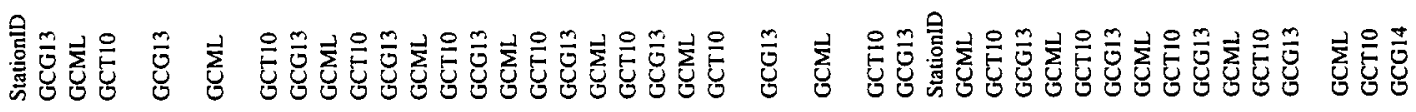




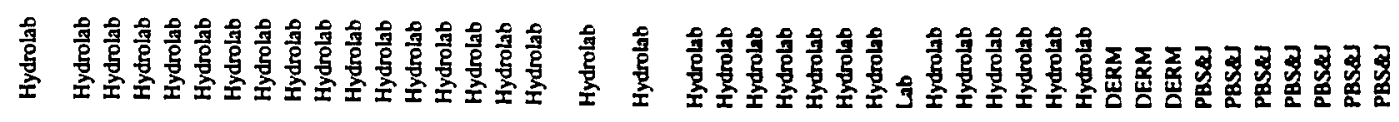

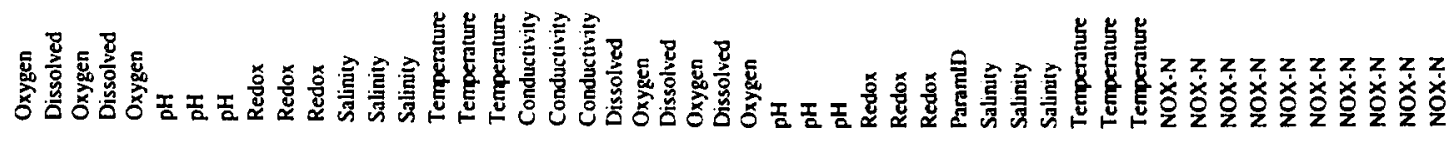

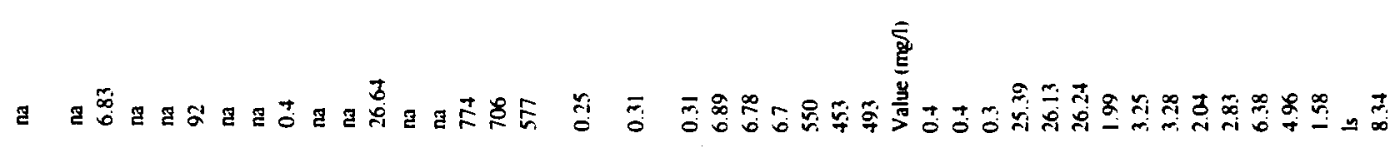

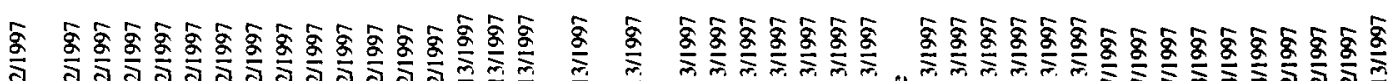

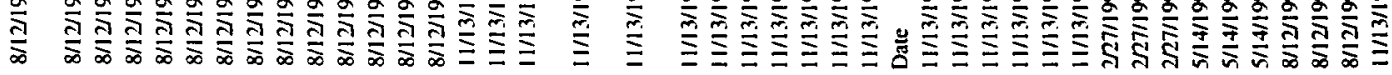

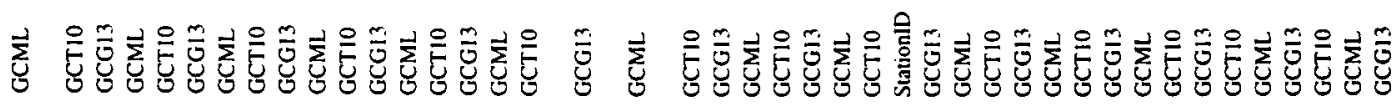

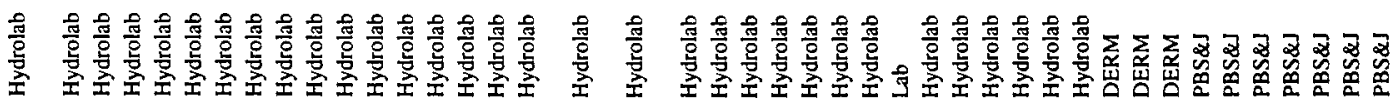

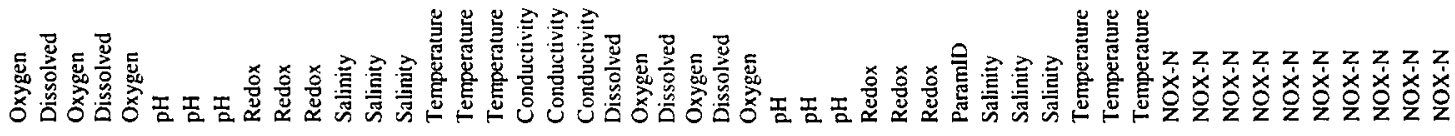

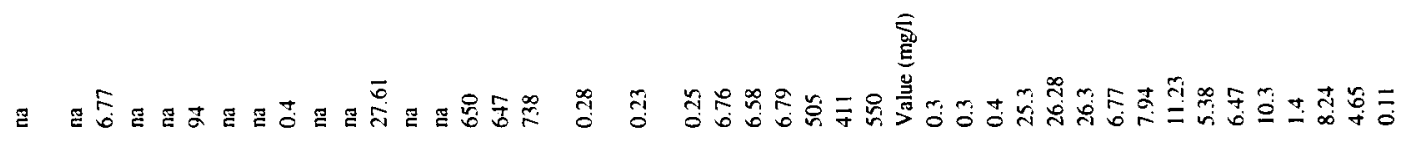

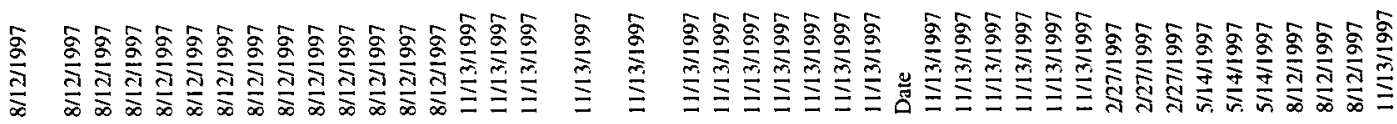

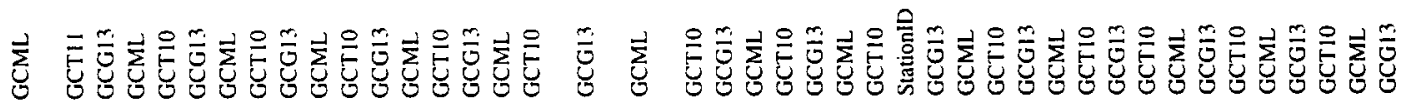




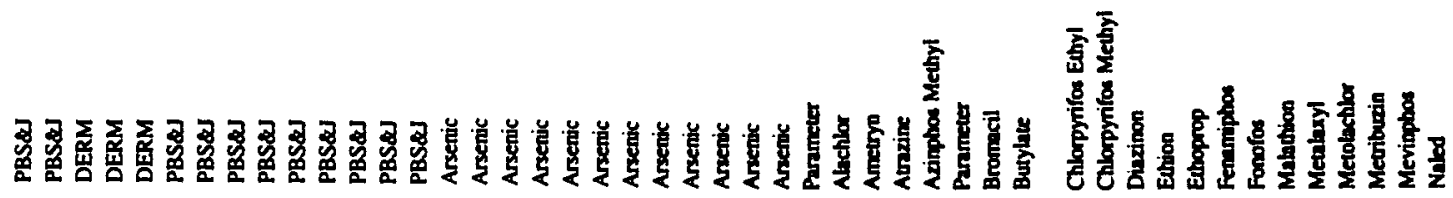

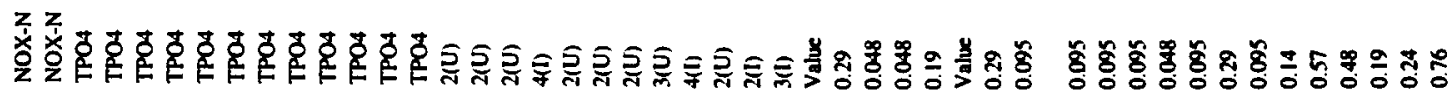

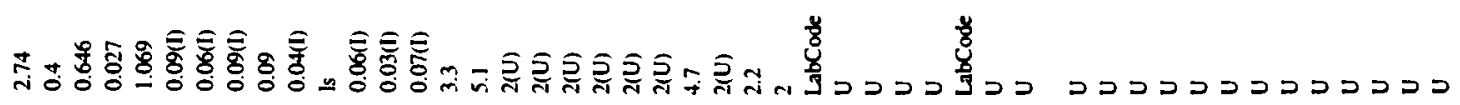

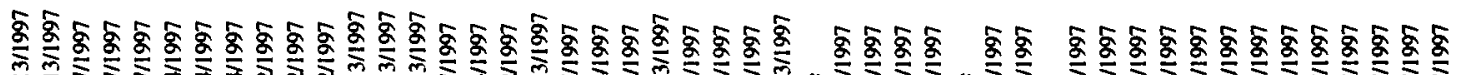

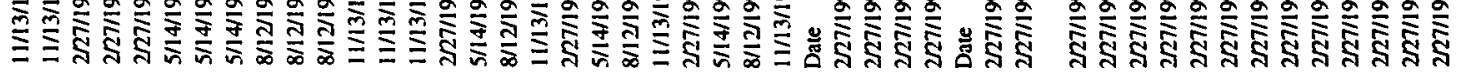

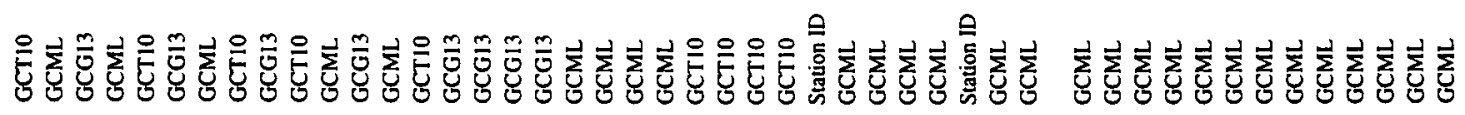

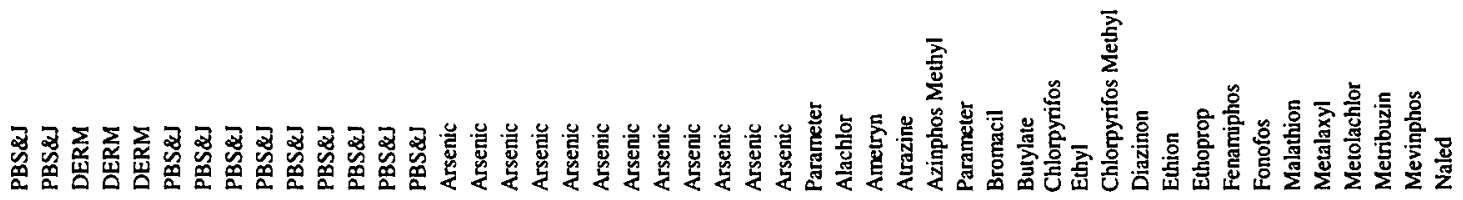

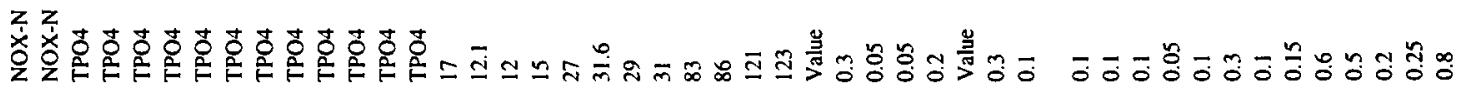

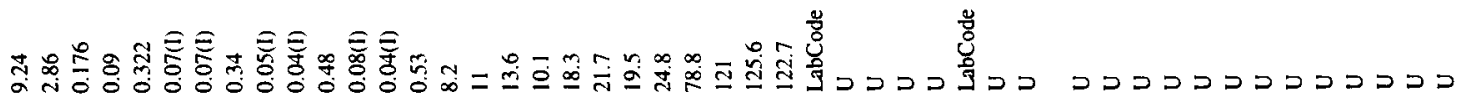

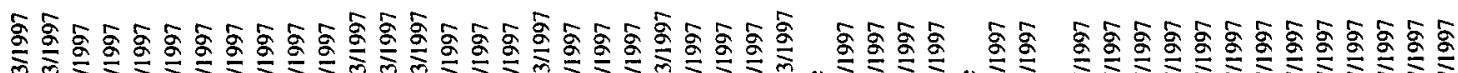

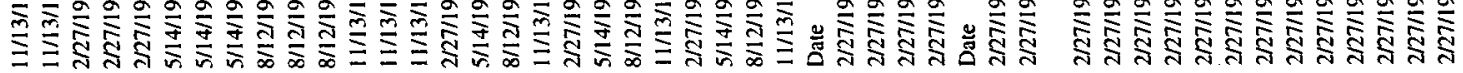

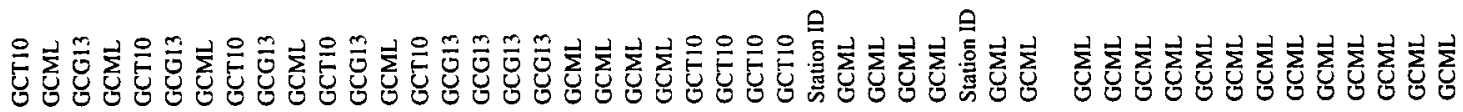




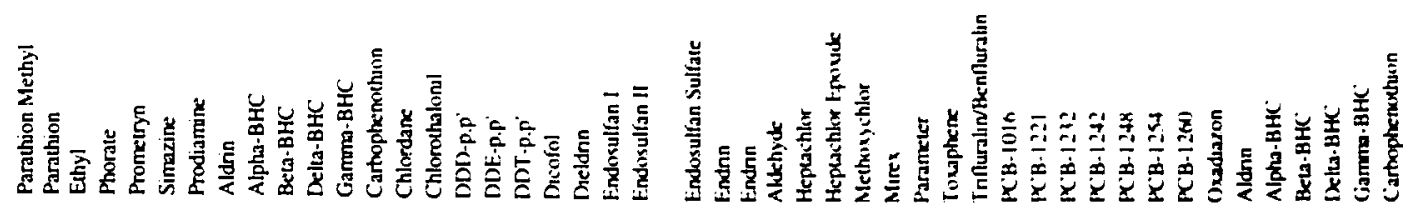

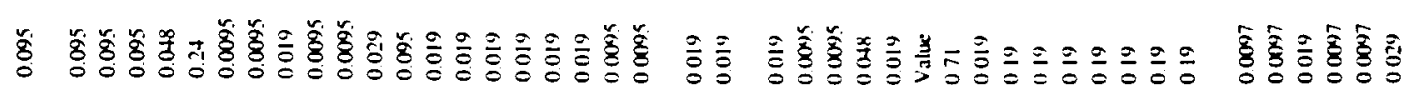

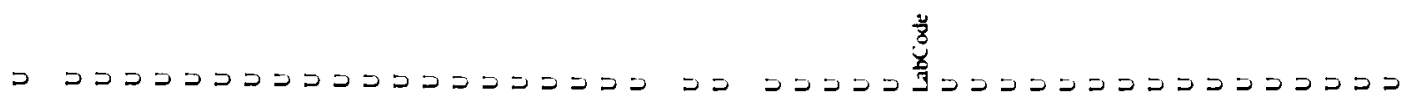

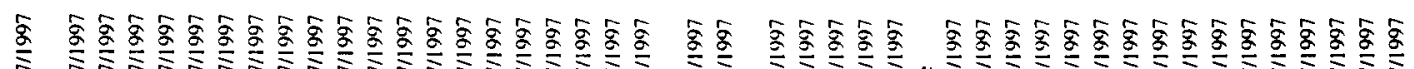

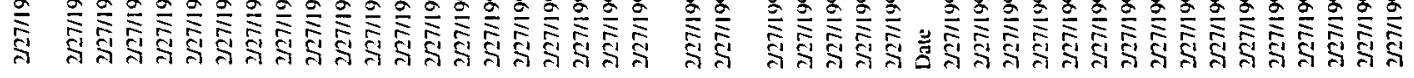

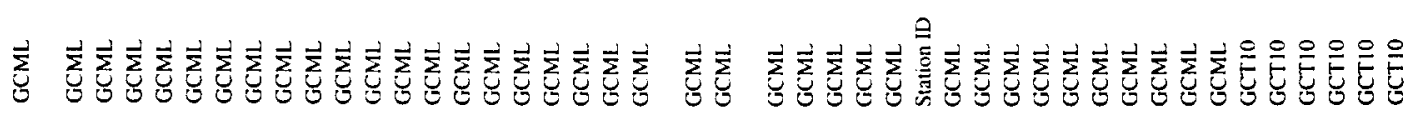

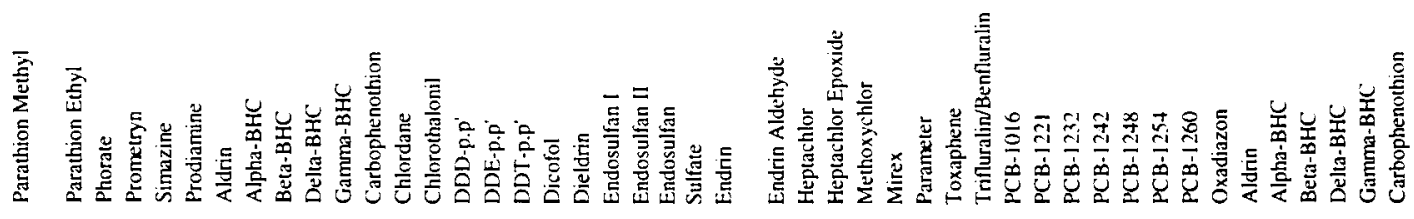

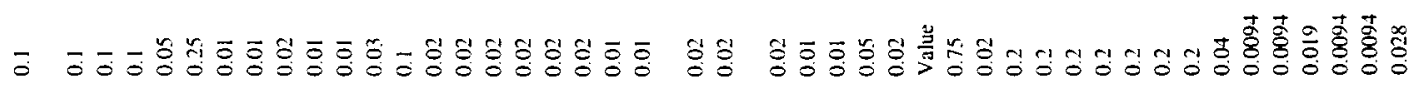

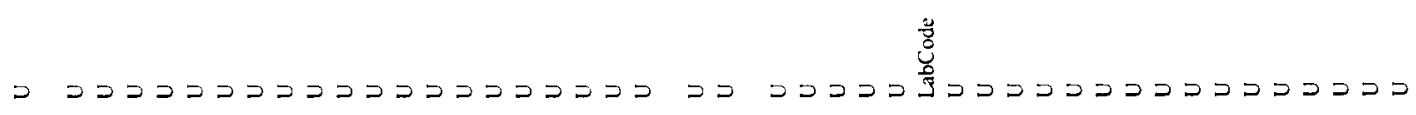

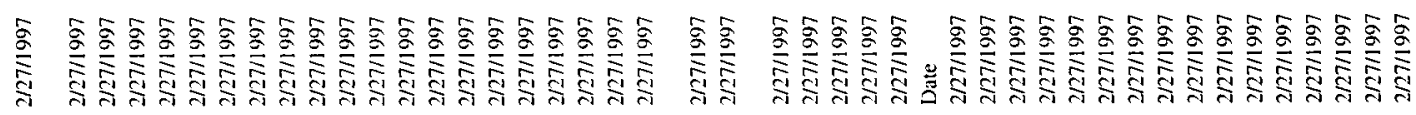

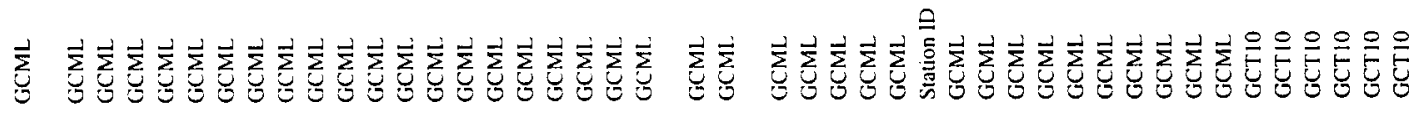




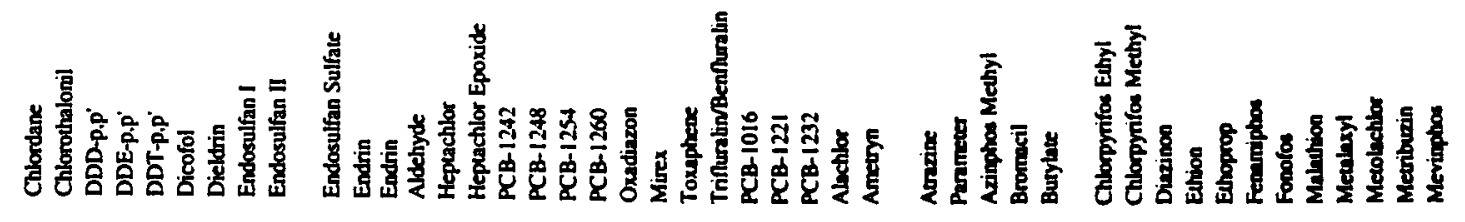

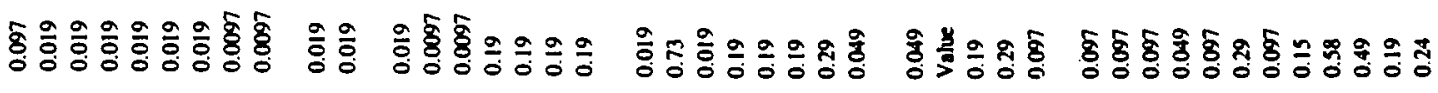

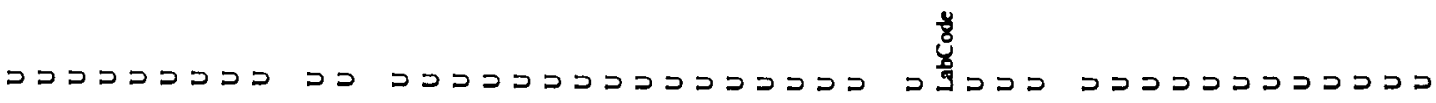

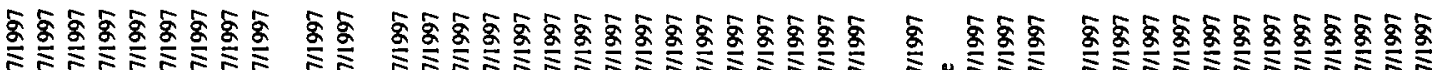

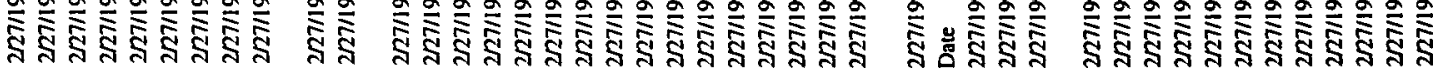

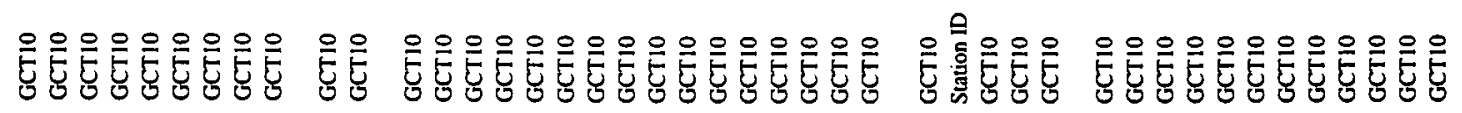

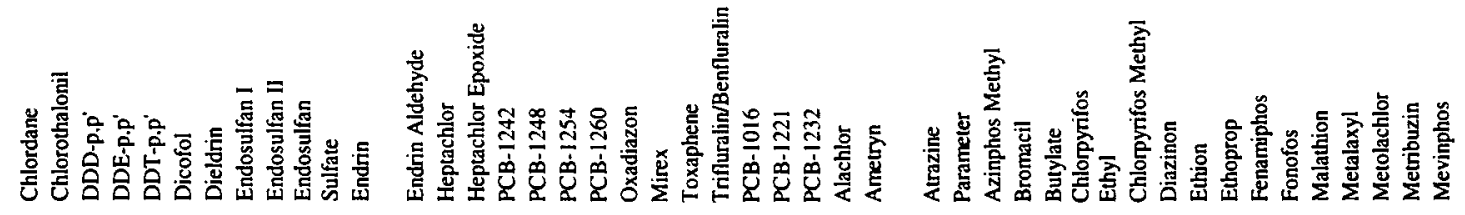

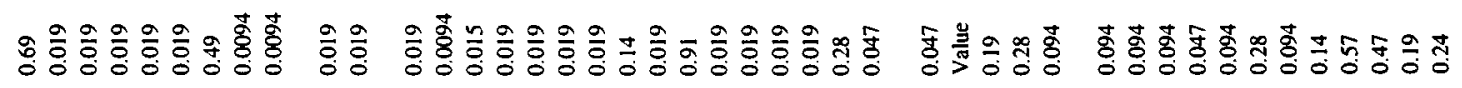

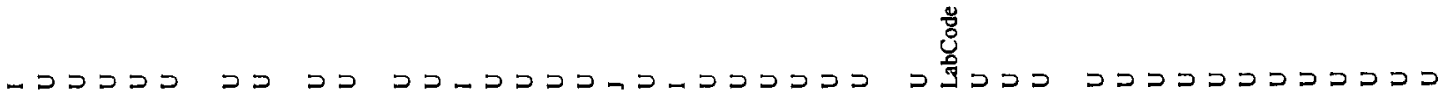

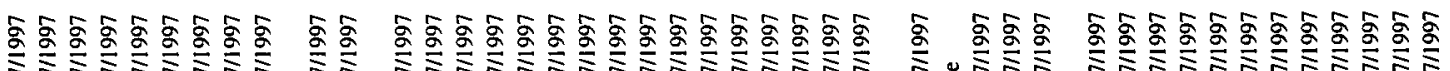

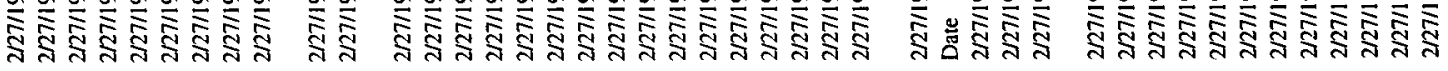

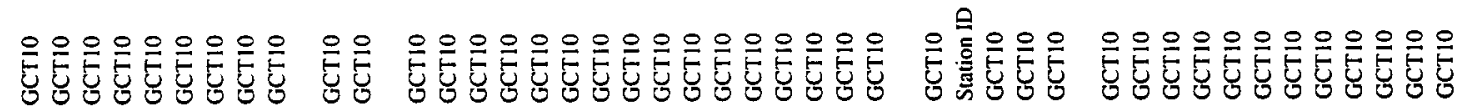




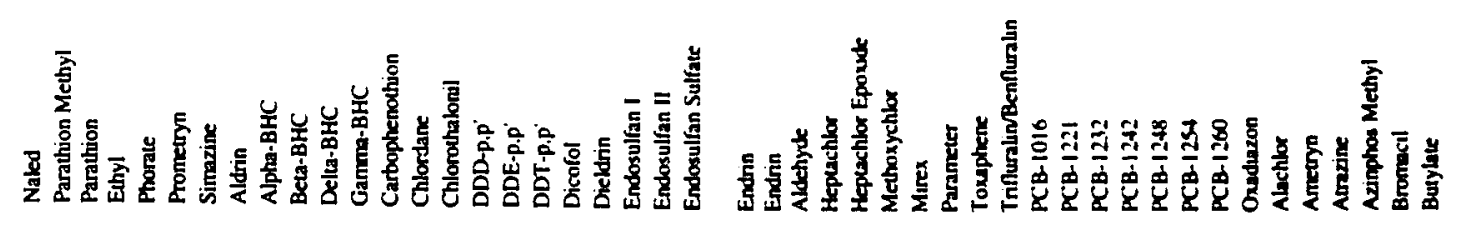

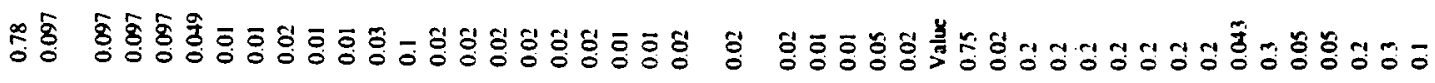

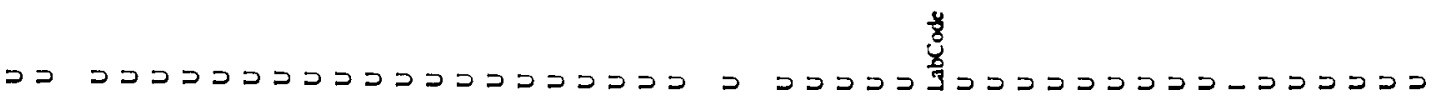

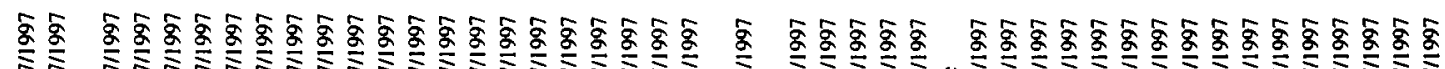

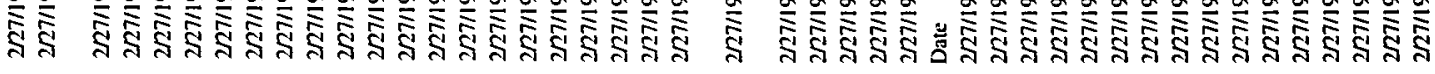

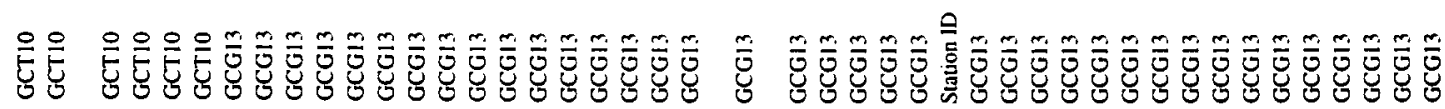

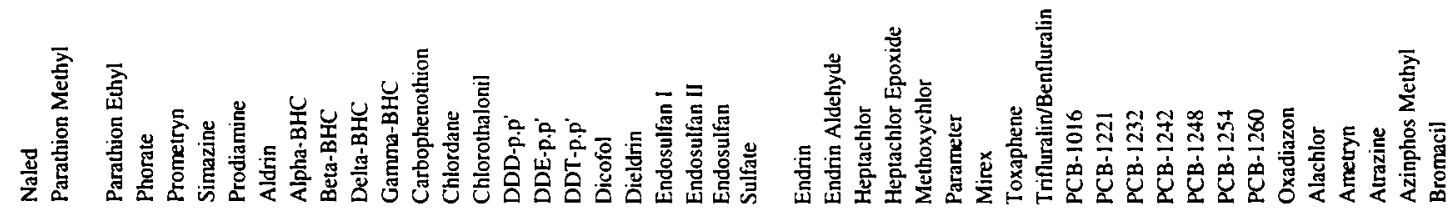

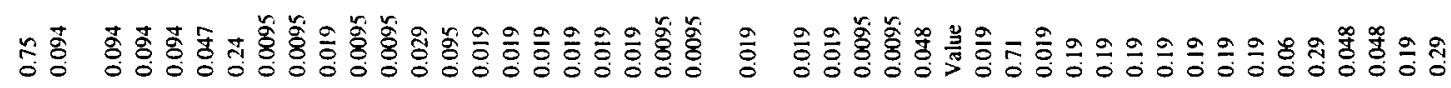

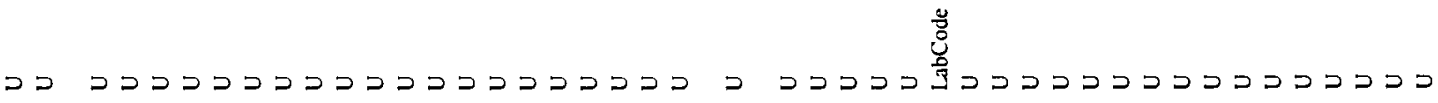

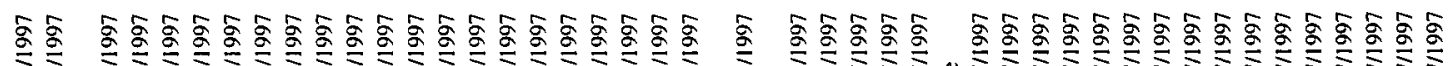

3.

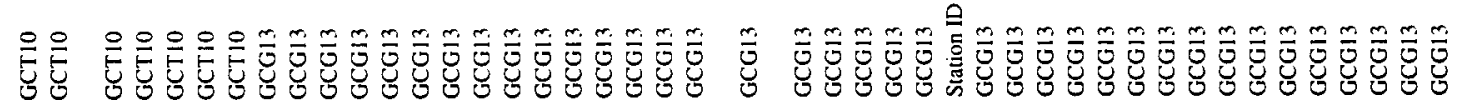




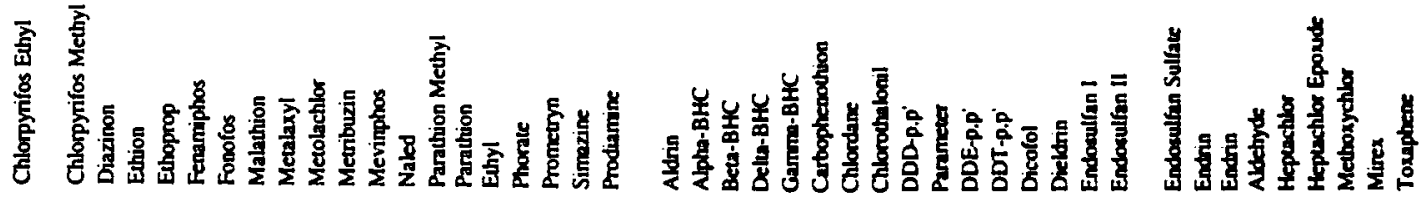

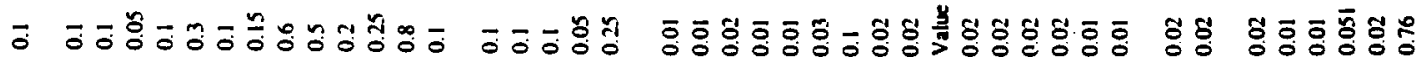

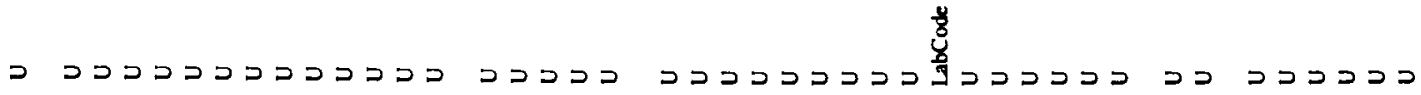

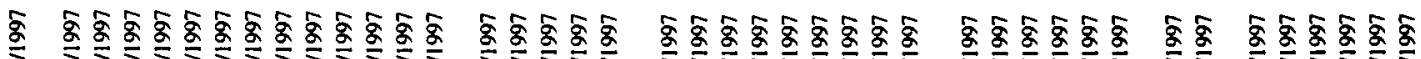
势

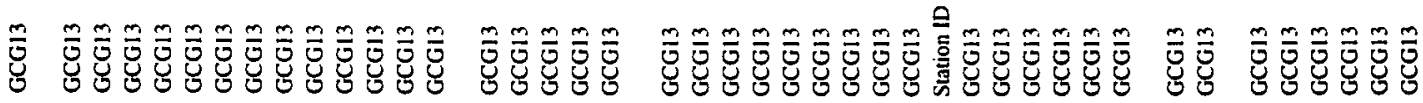

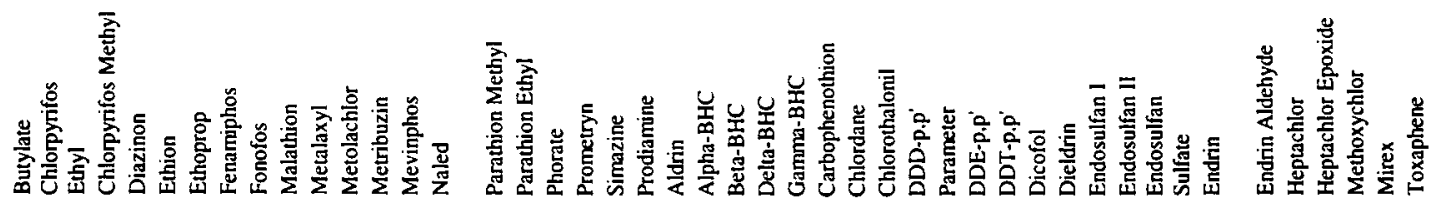

总

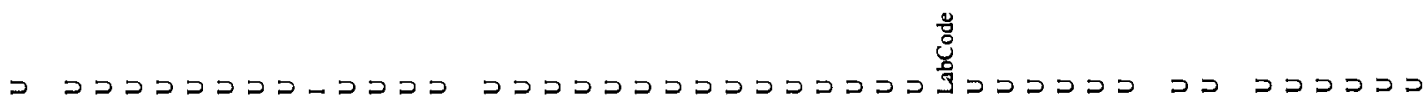

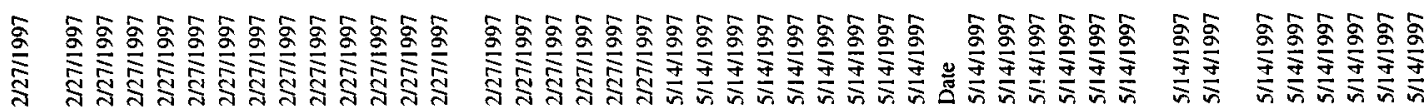

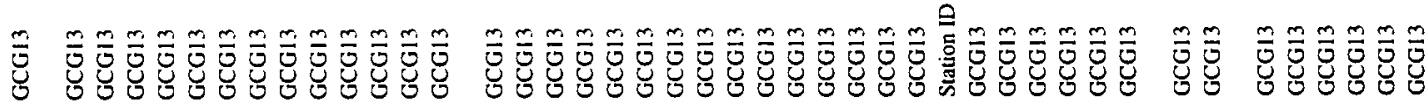




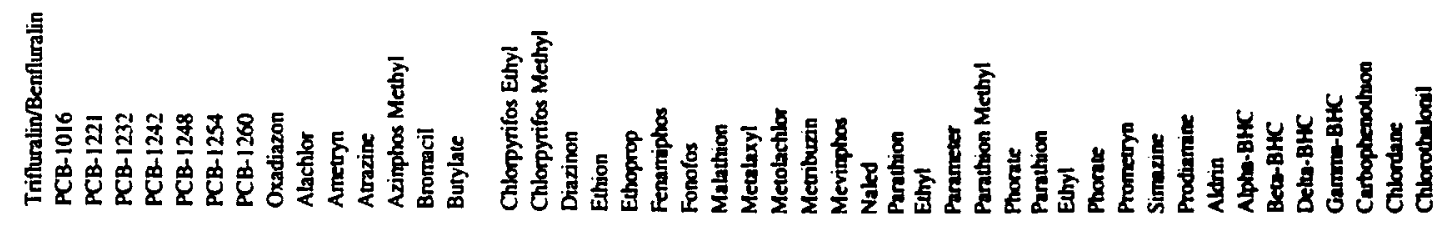

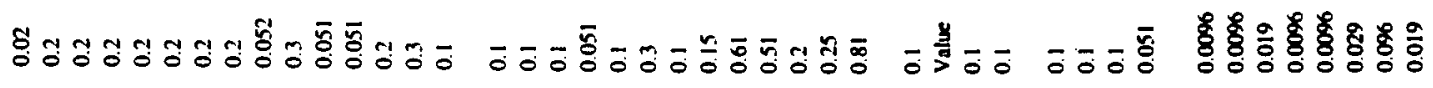

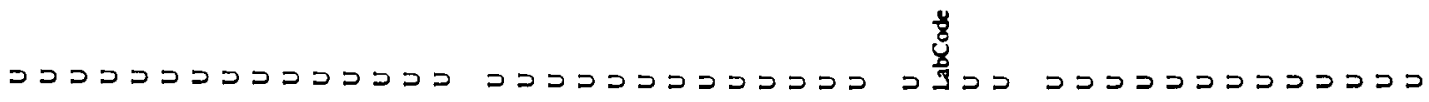

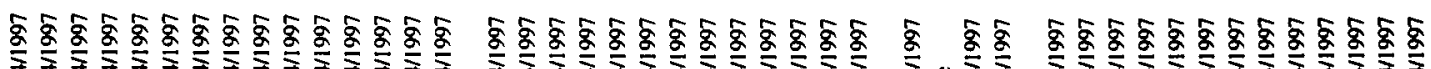

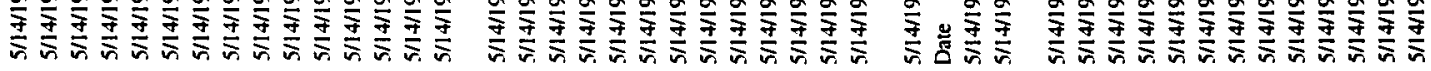

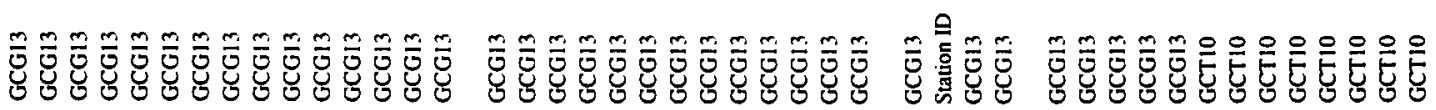

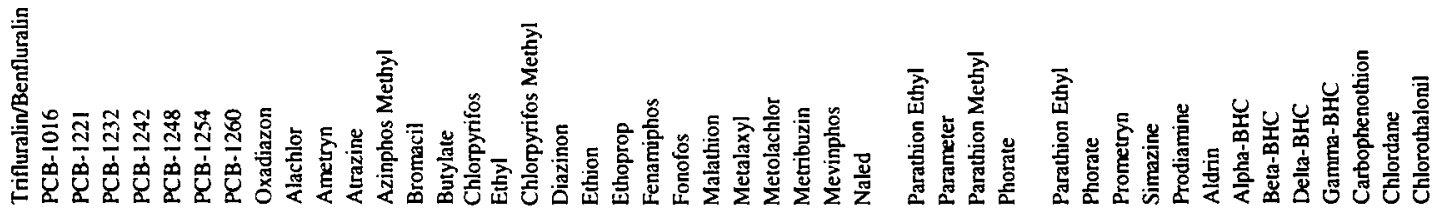

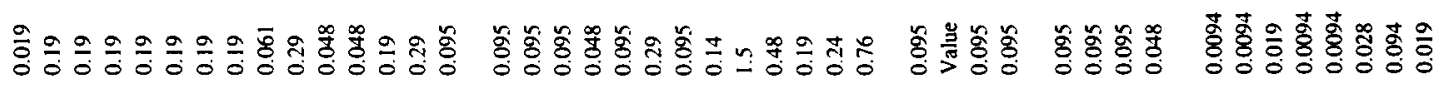

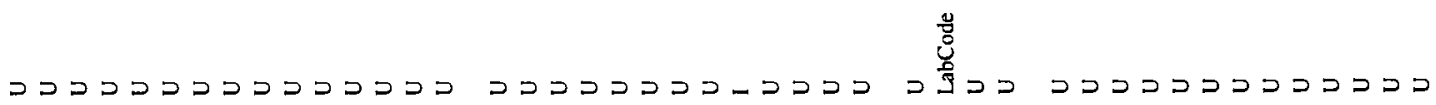

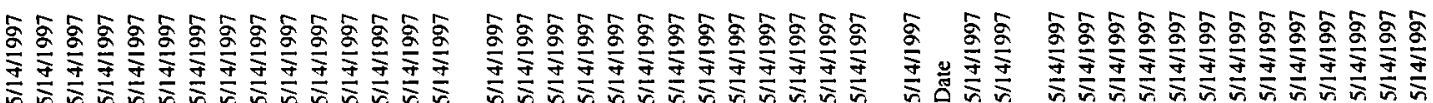

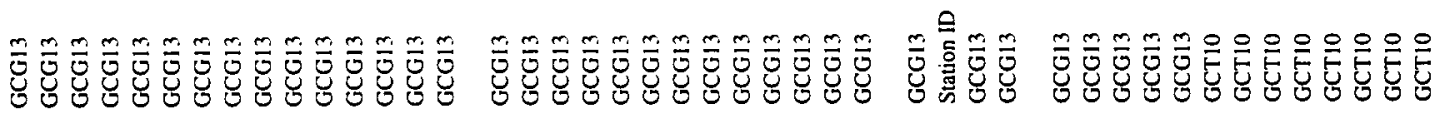




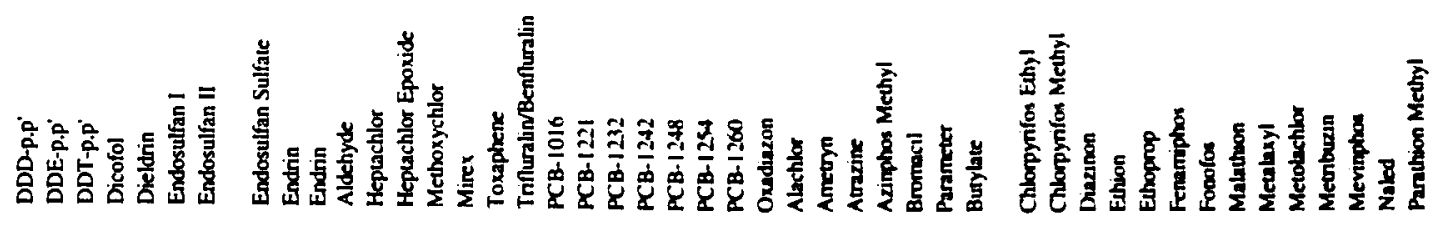

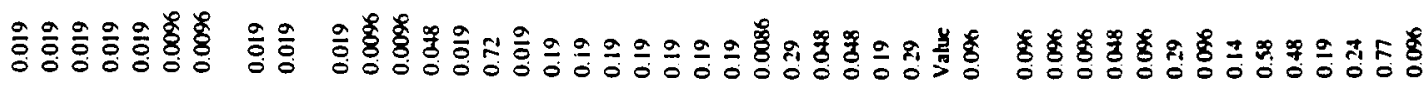

D

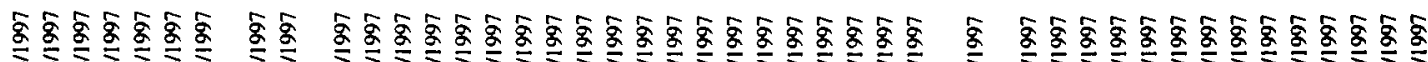

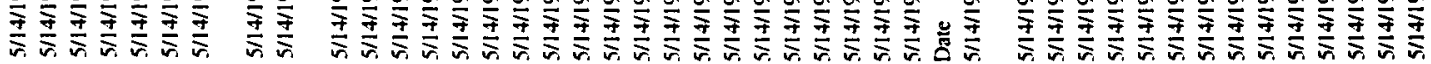

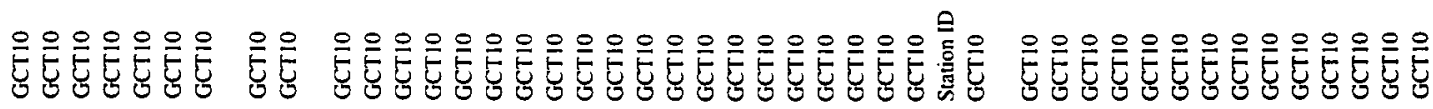

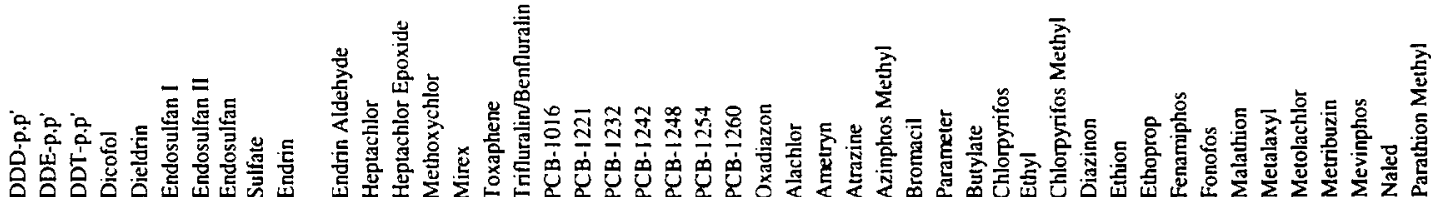

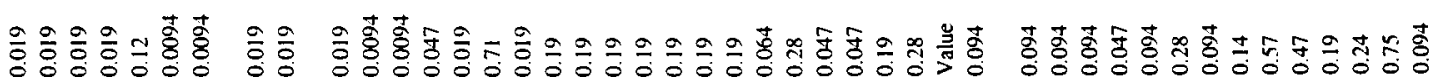

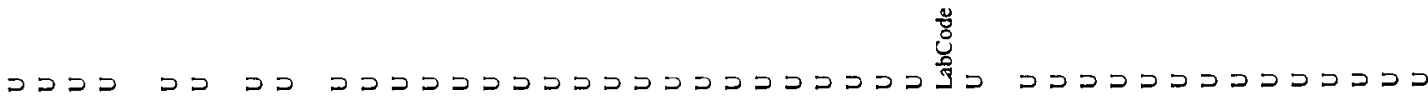

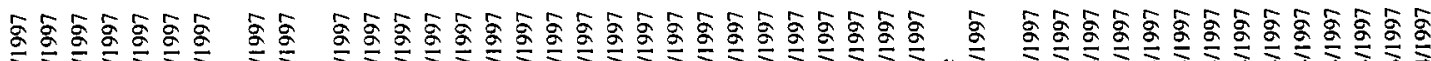

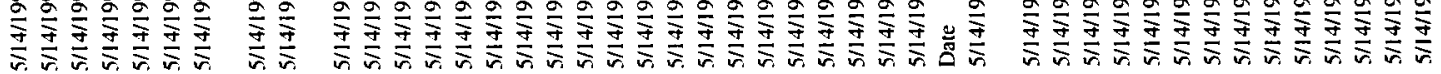

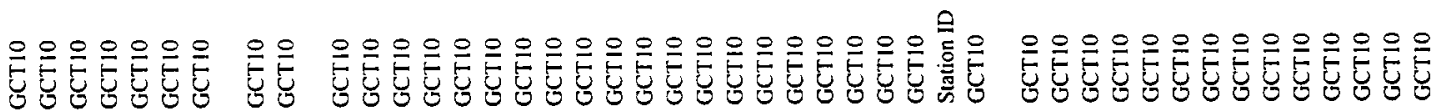




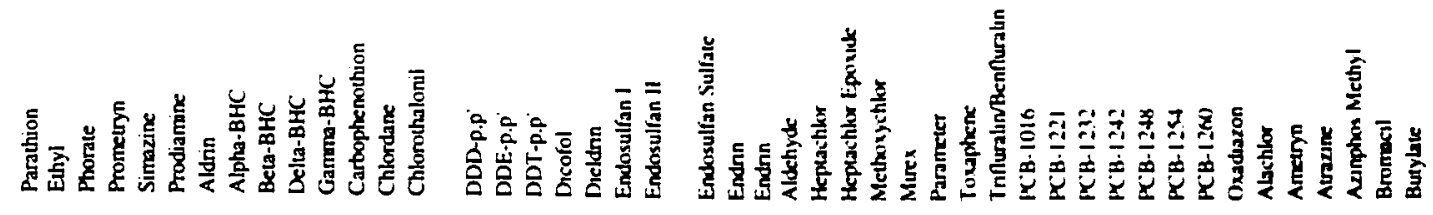

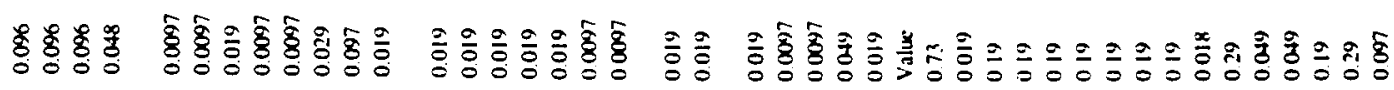

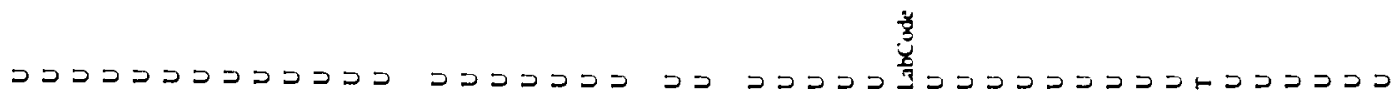

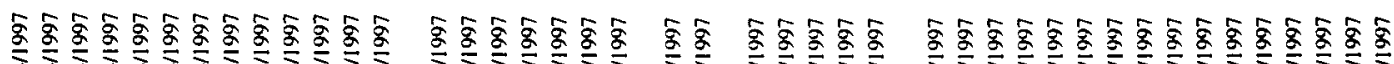

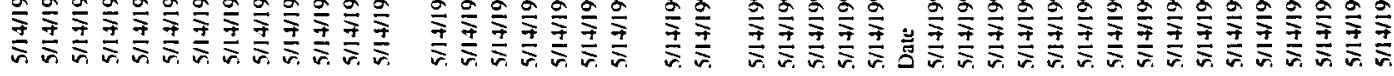

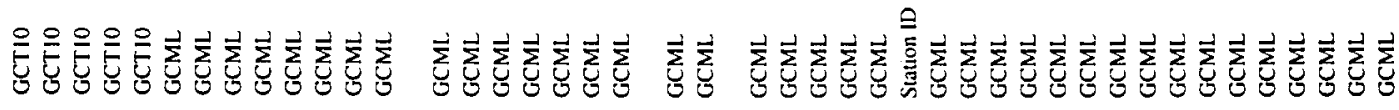

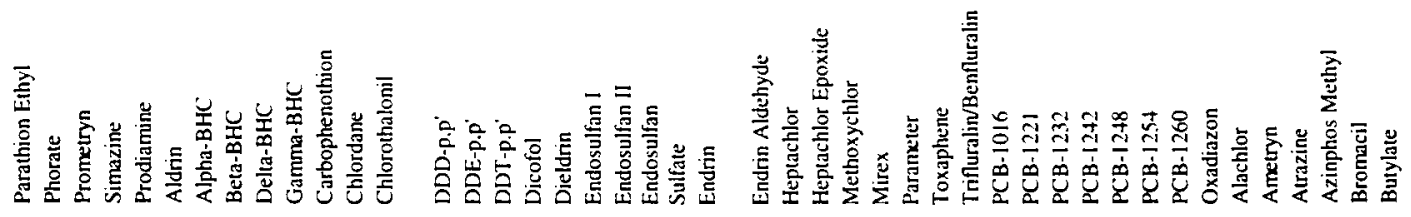

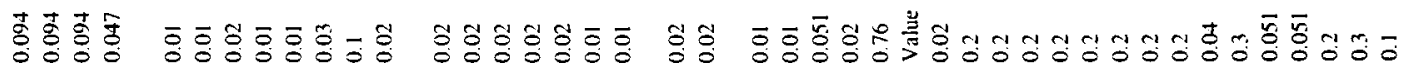

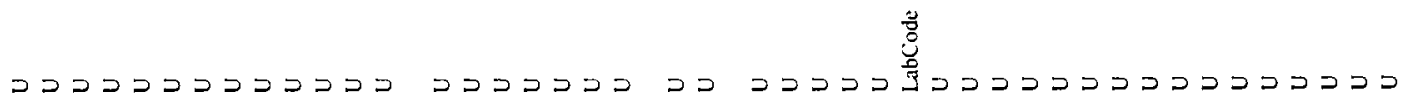

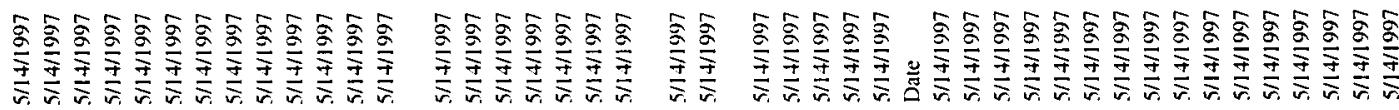

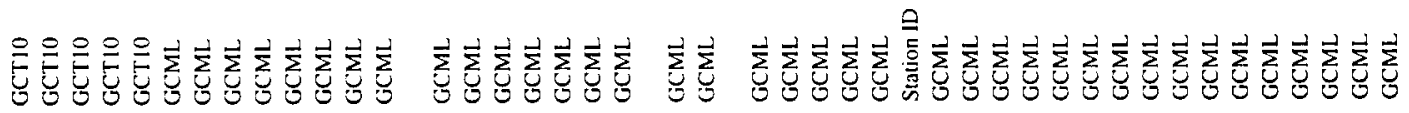




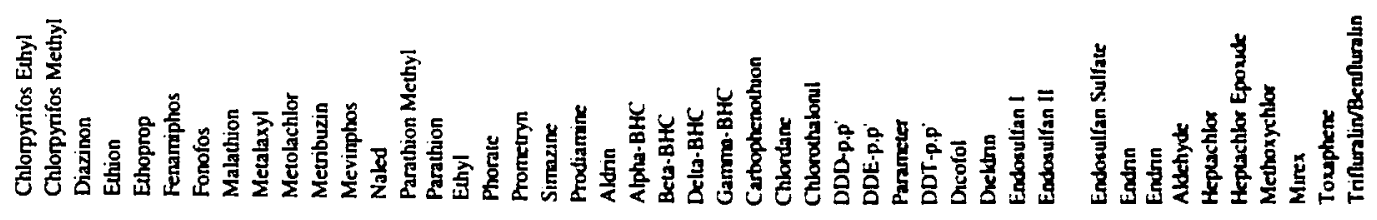

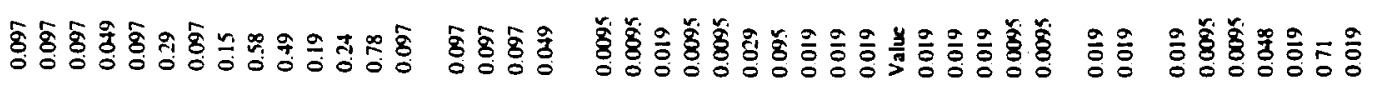

渵

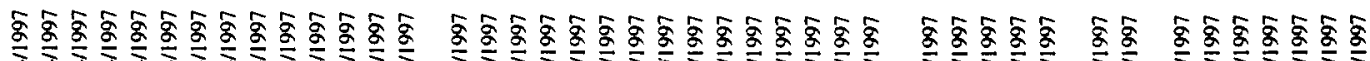

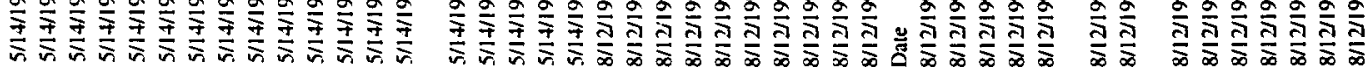

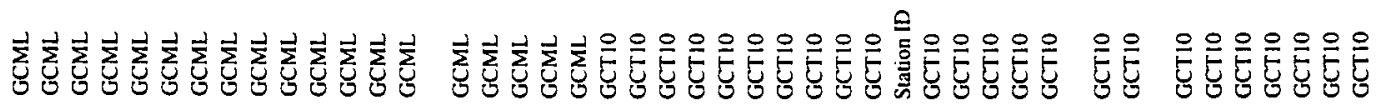

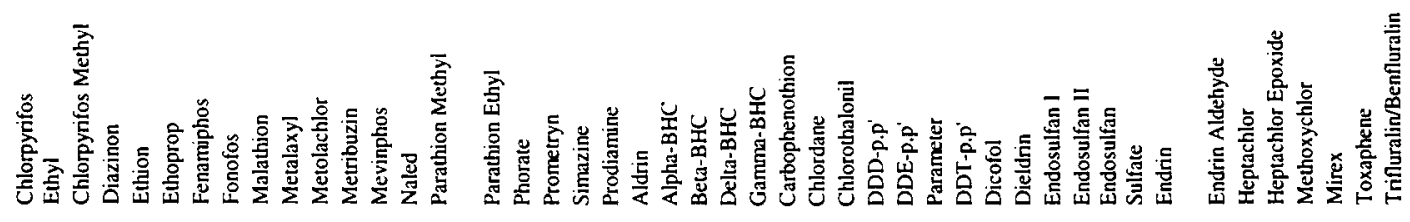

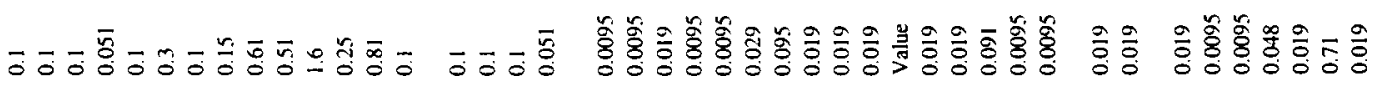

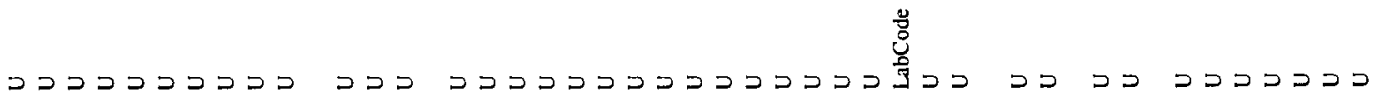

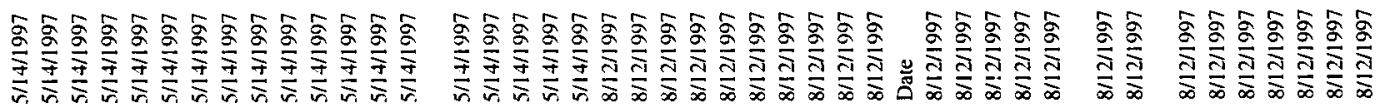

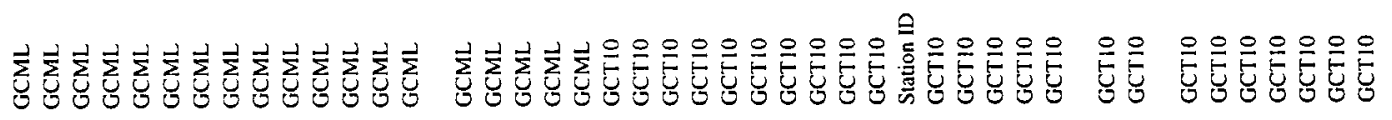




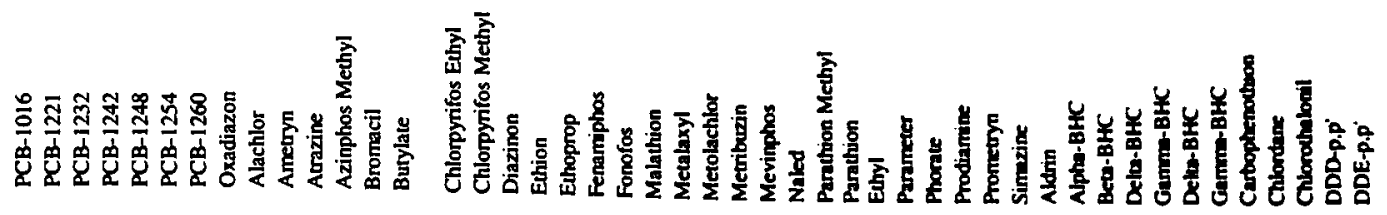

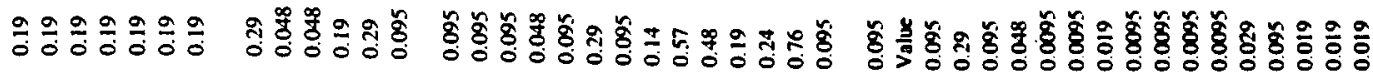

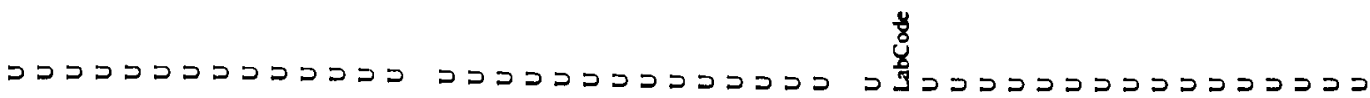

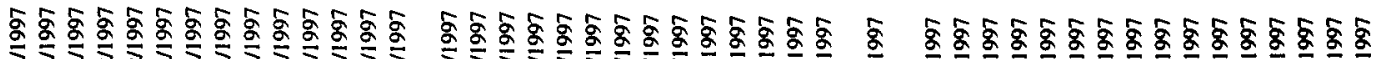

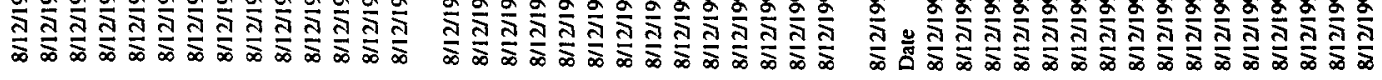

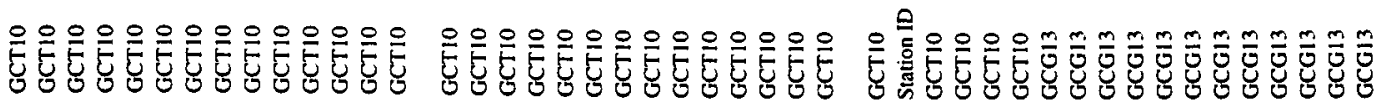

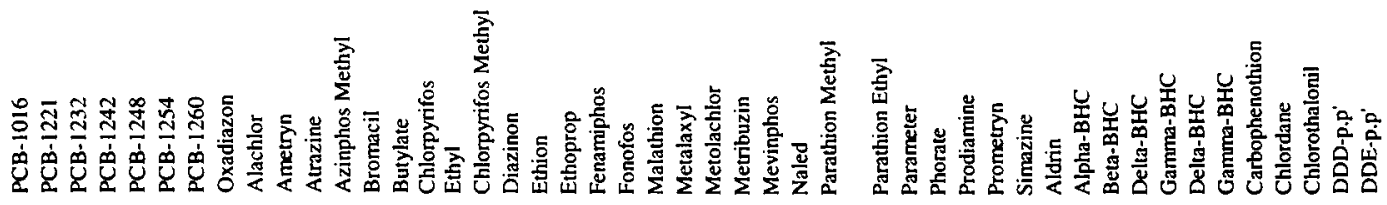

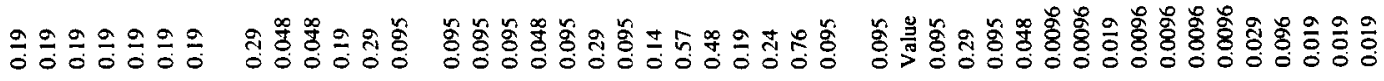

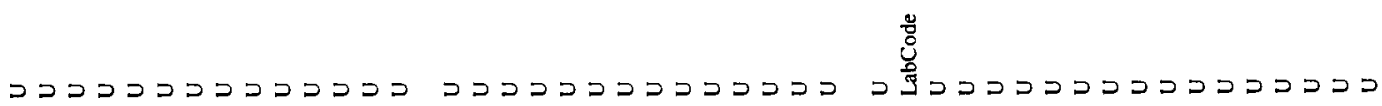

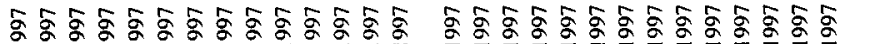
ง

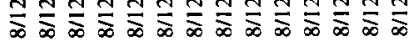

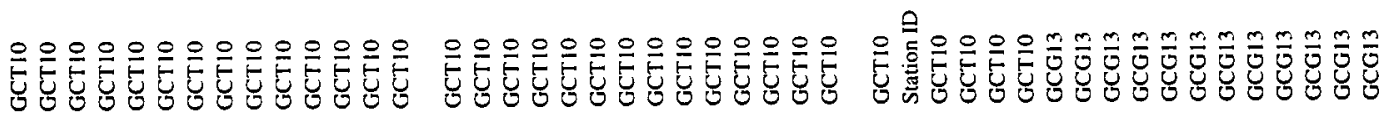




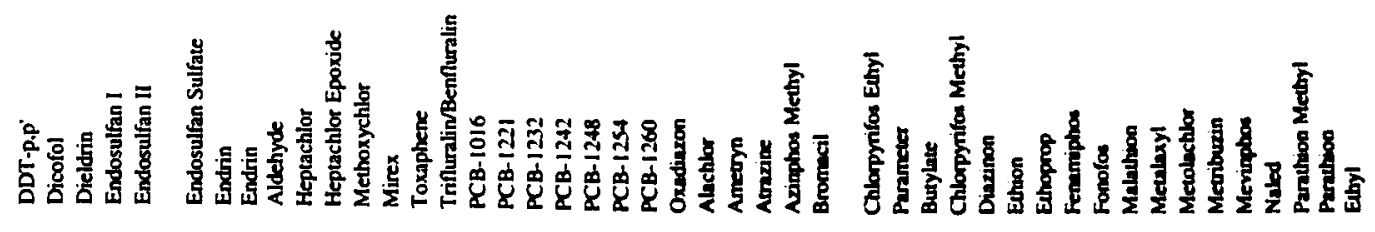

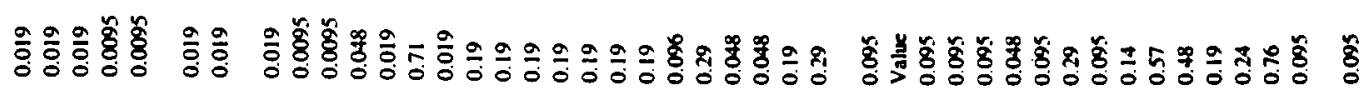

|

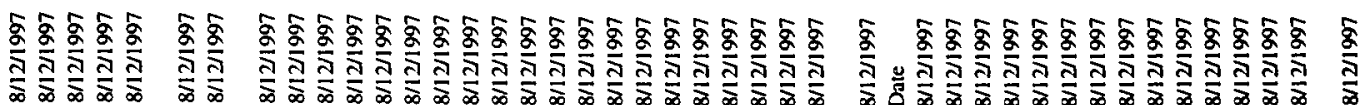

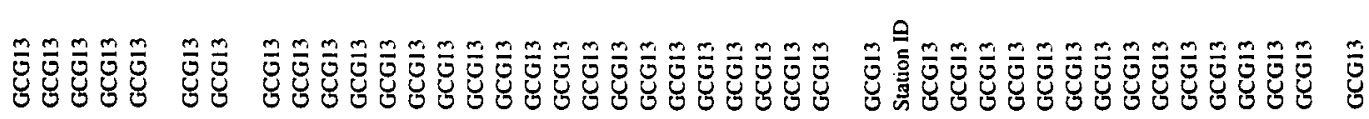

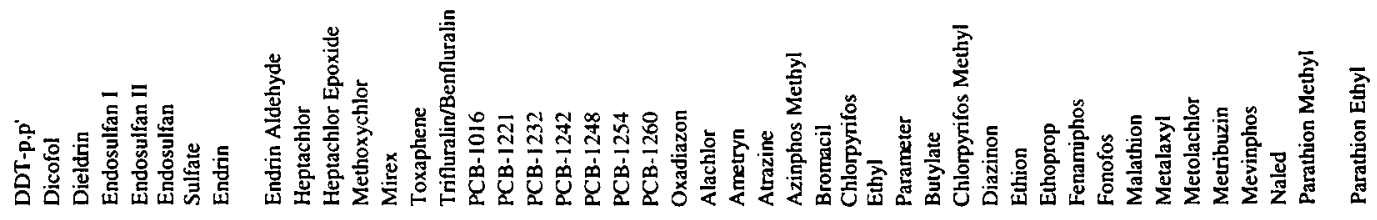

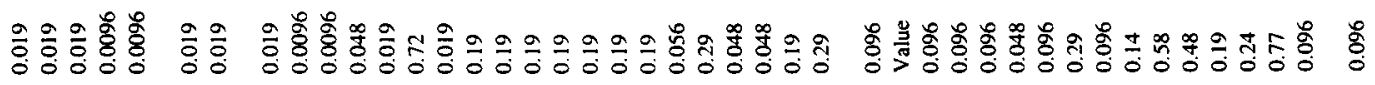

מ

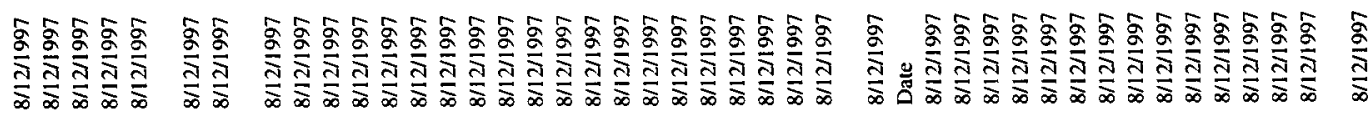

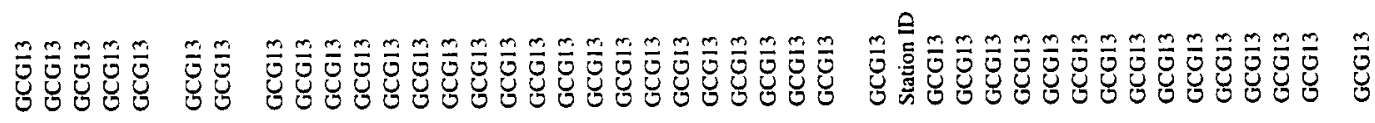




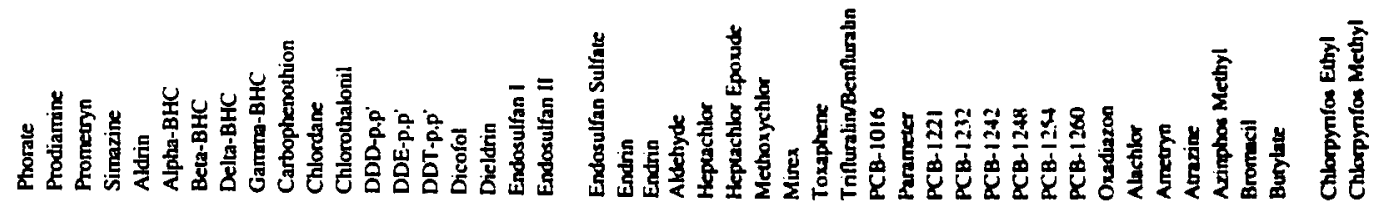

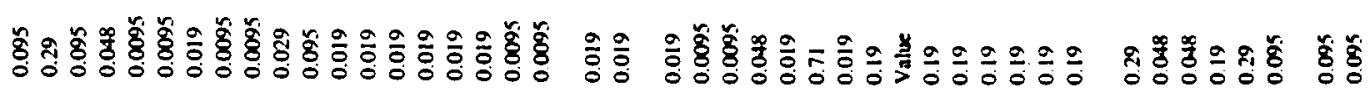

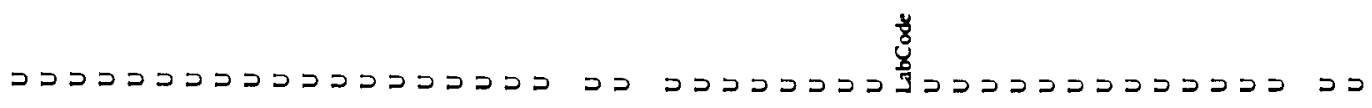

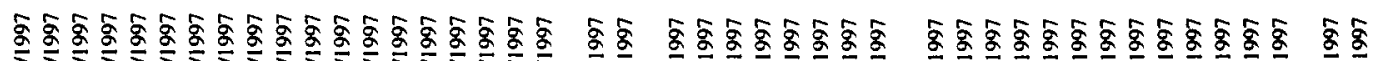

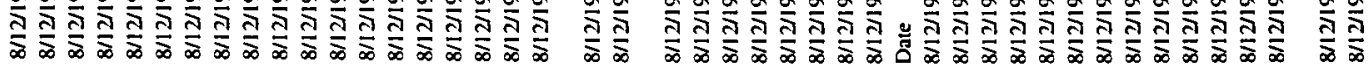

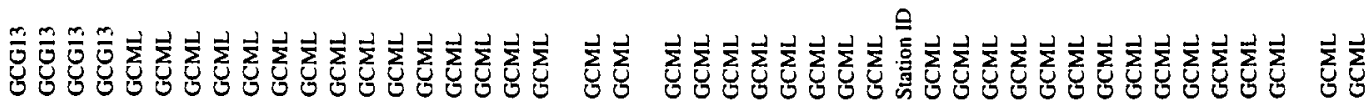

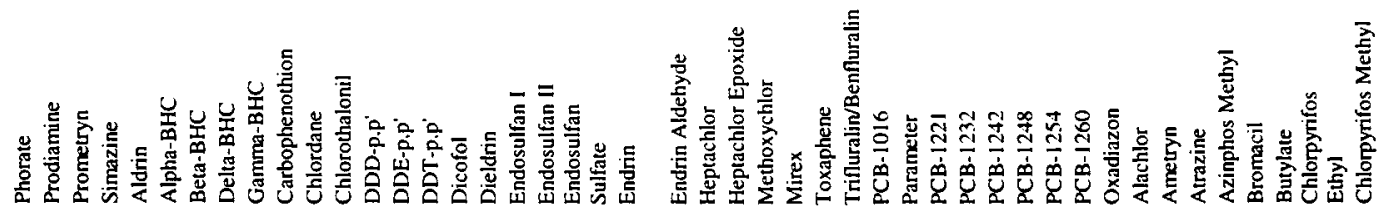

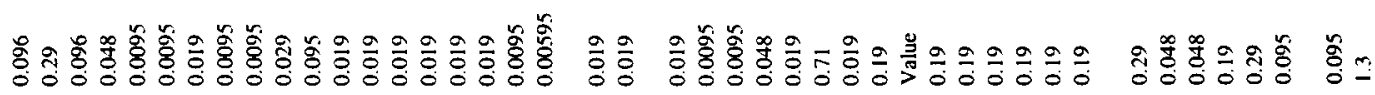

כ

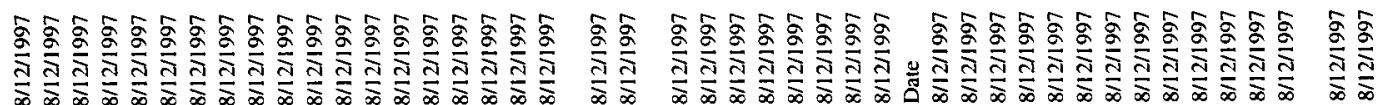

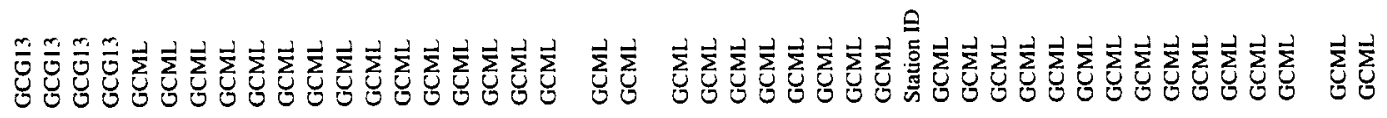




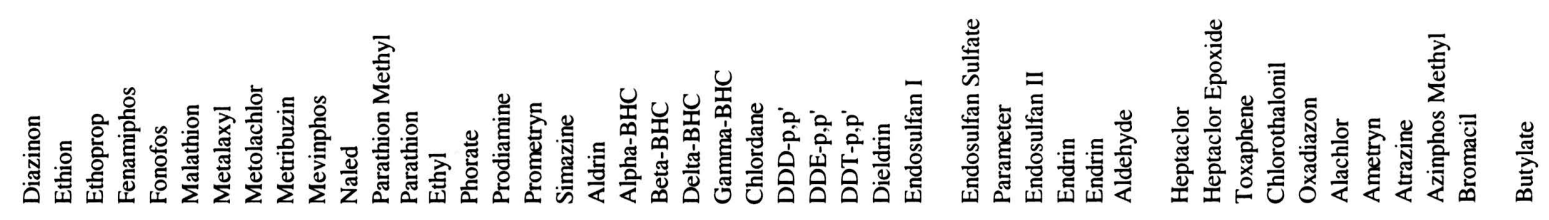

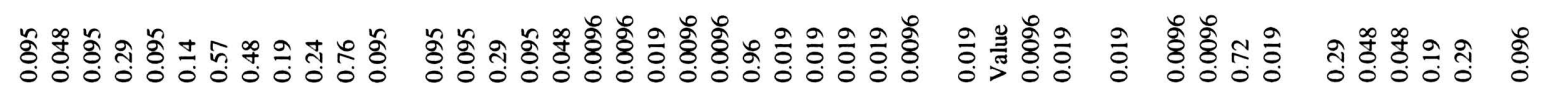

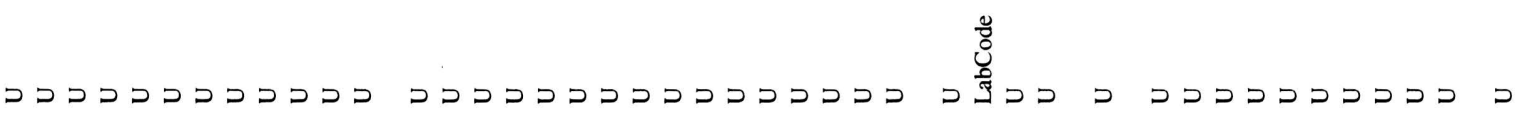

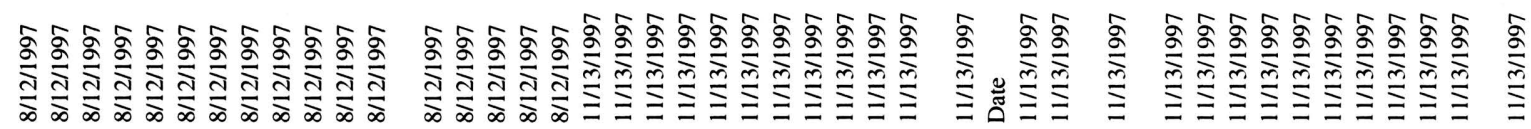

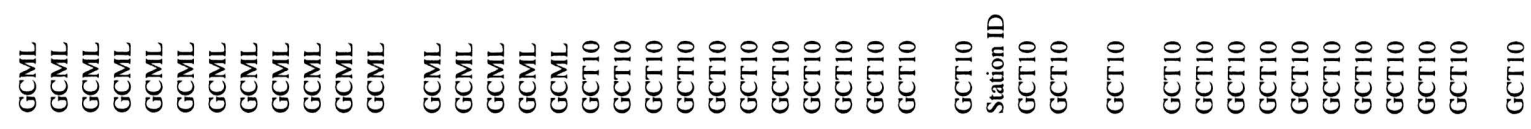

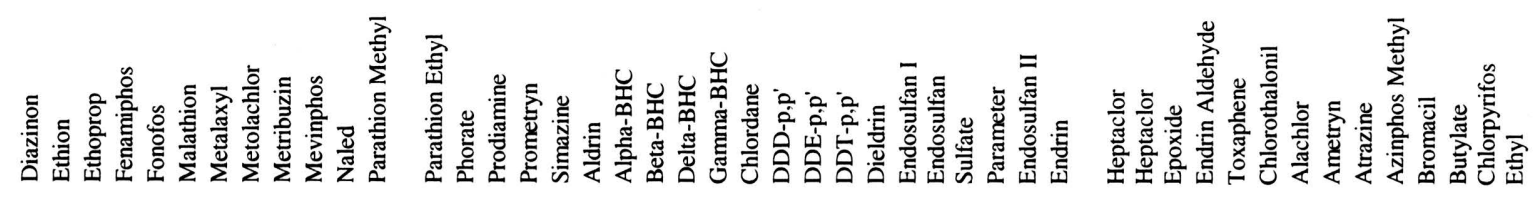

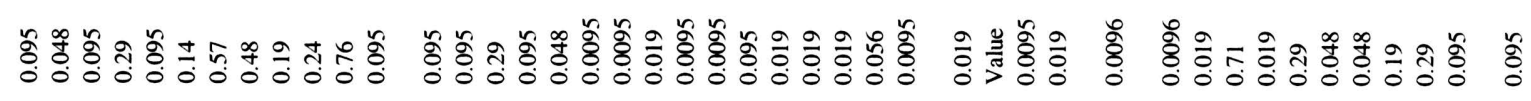

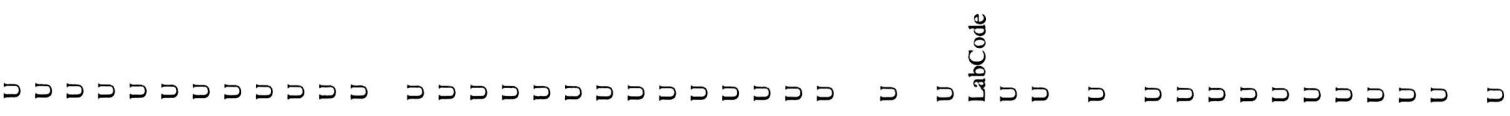

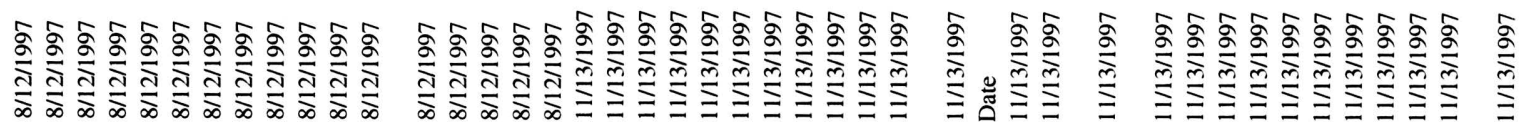

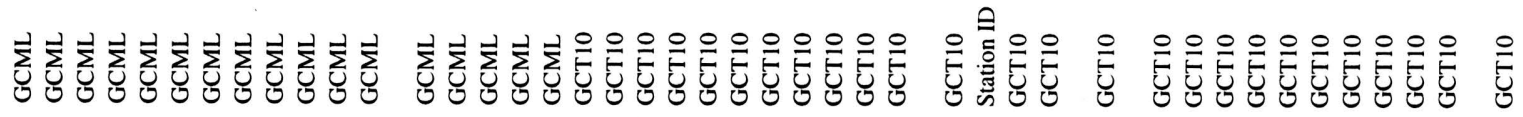




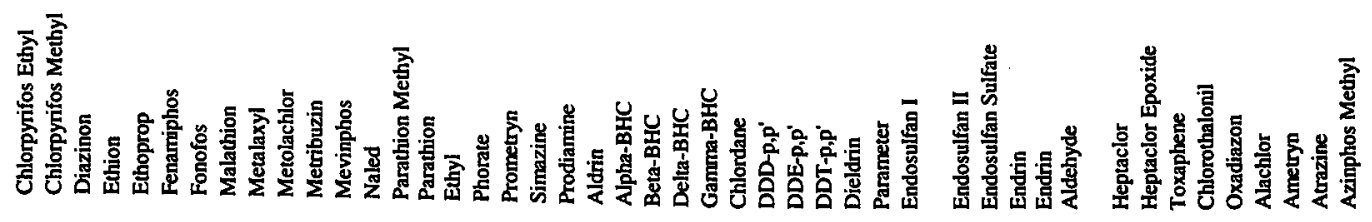

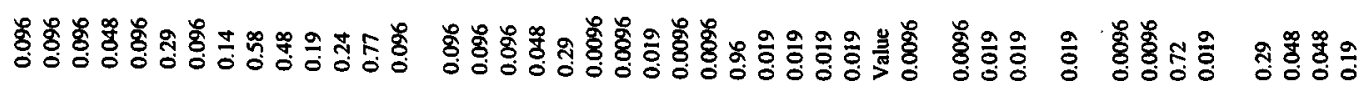

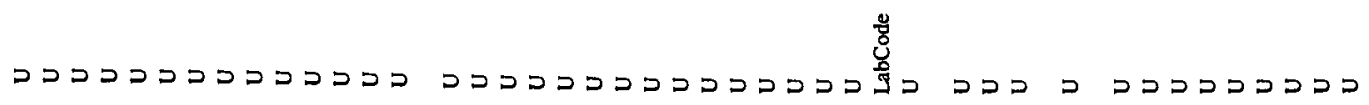

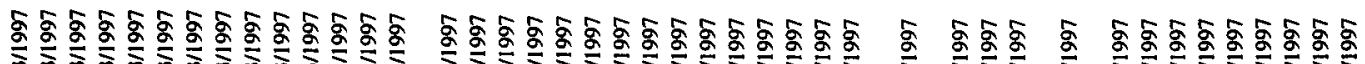

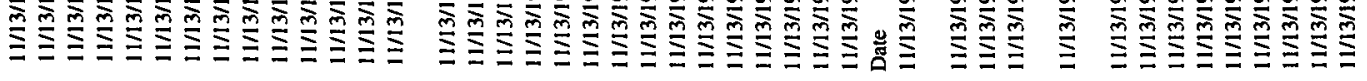

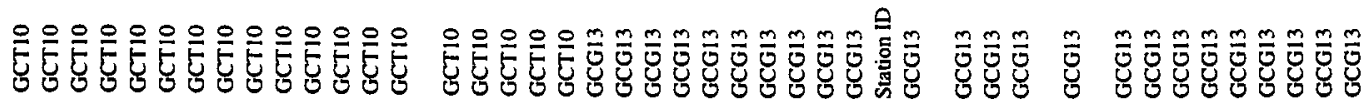

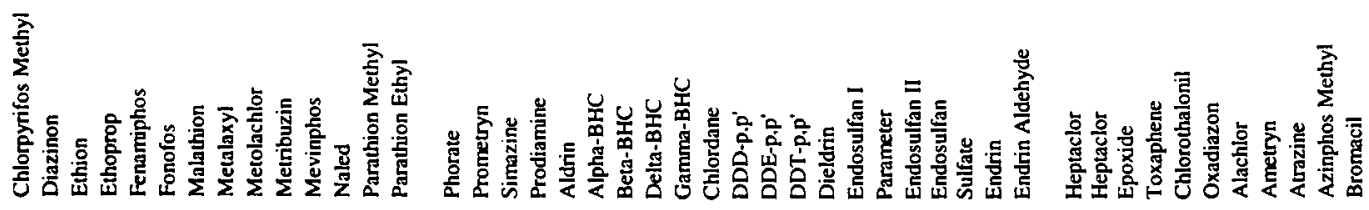

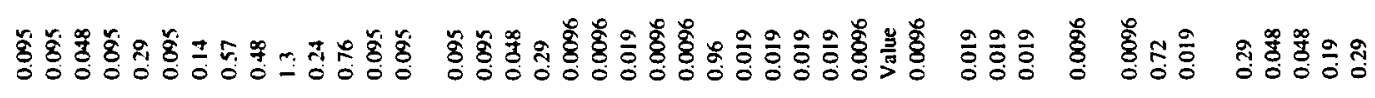

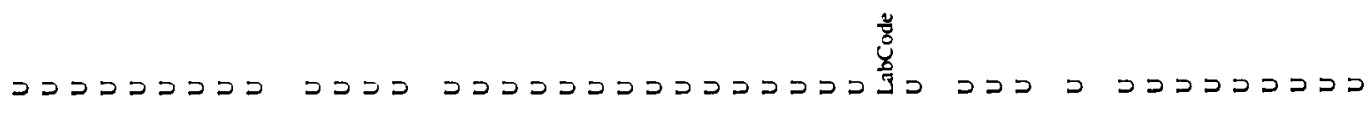

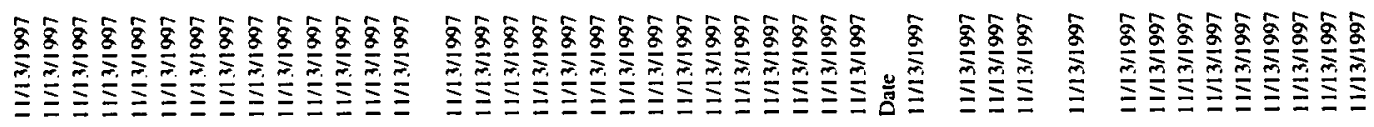

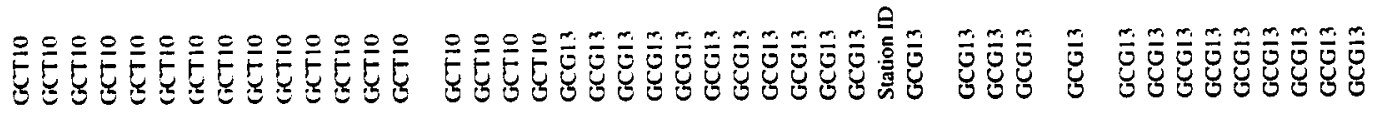




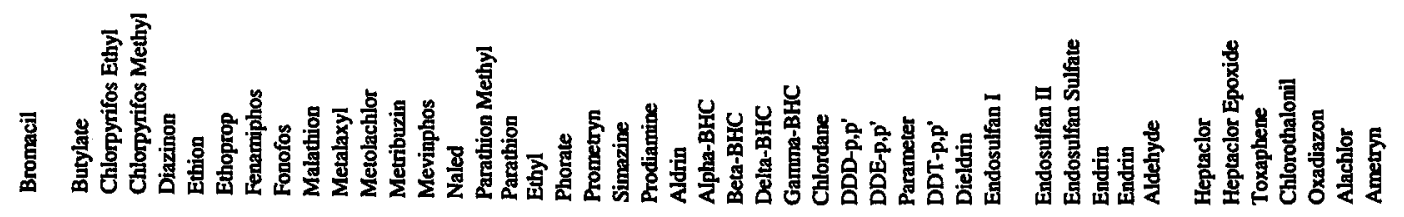

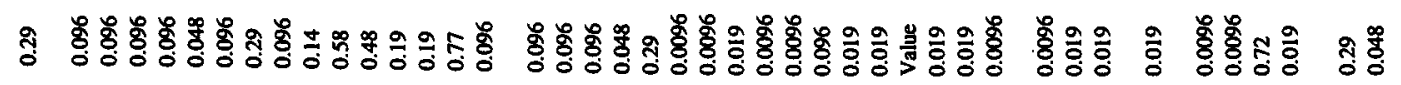

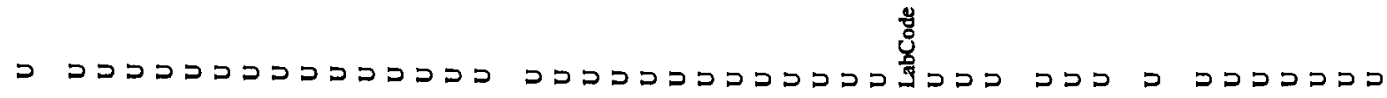

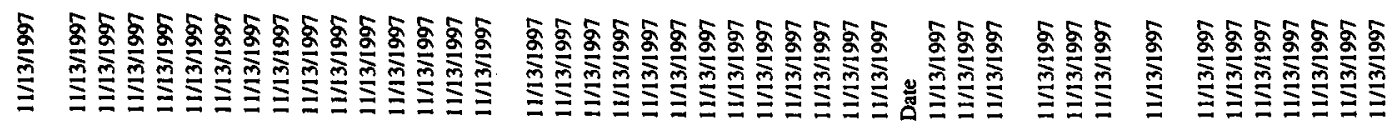

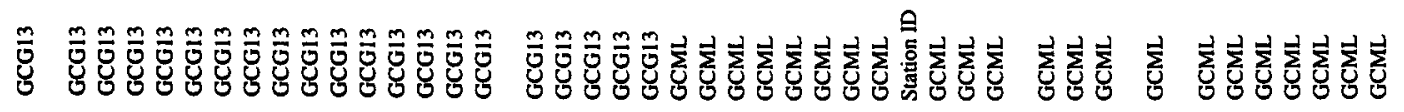

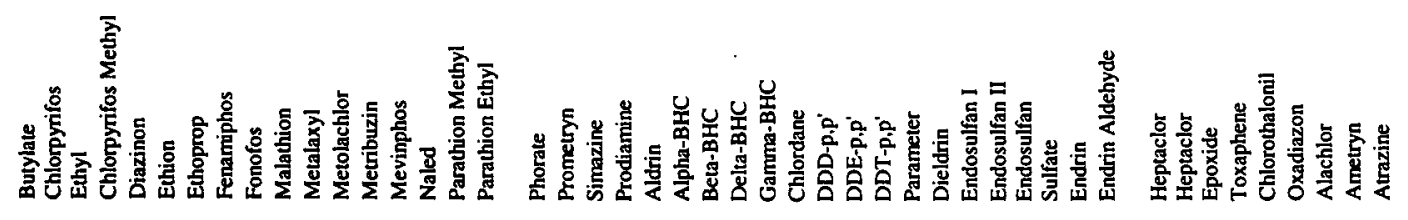

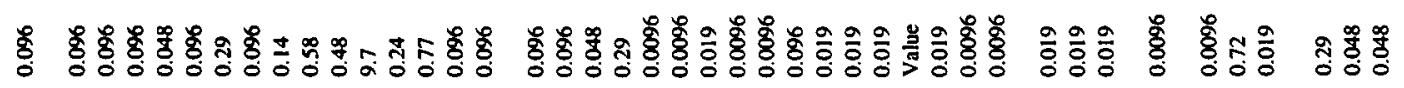

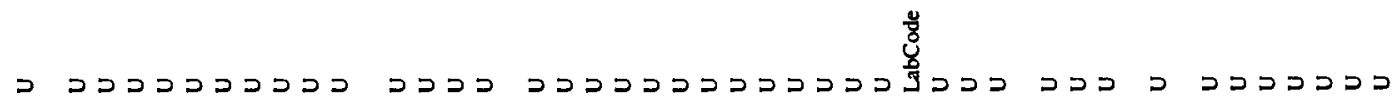

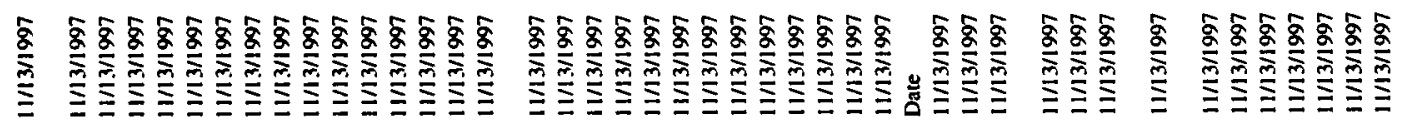

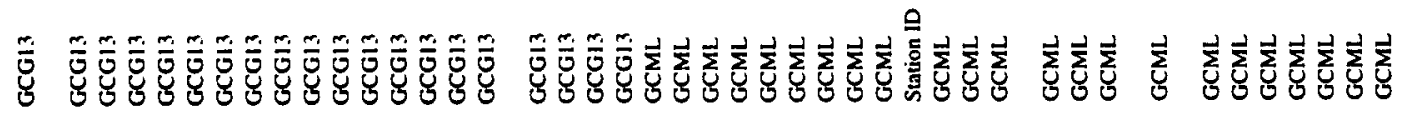




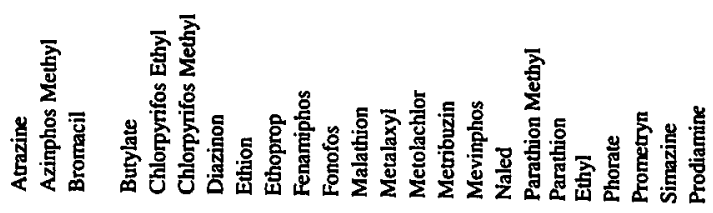

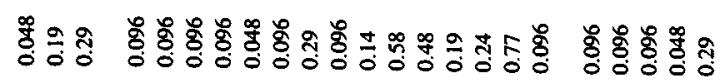

대

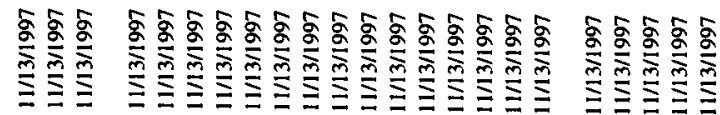

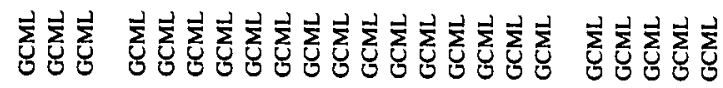

Wuntwinnm

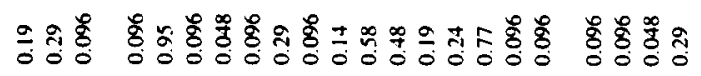

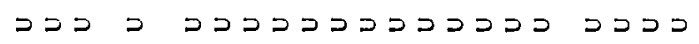

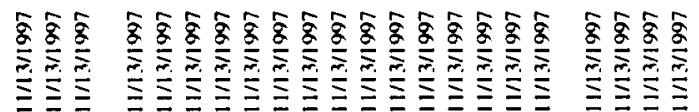

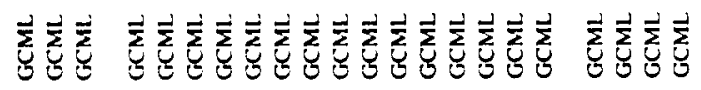




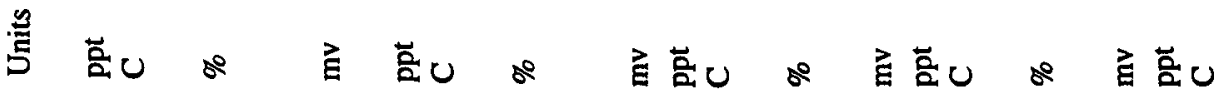

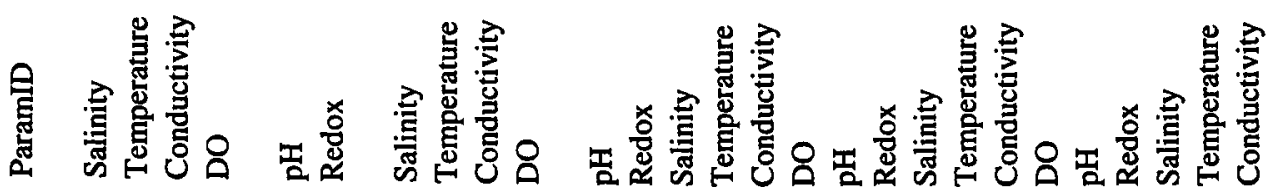

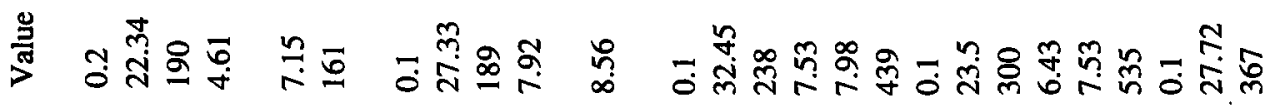

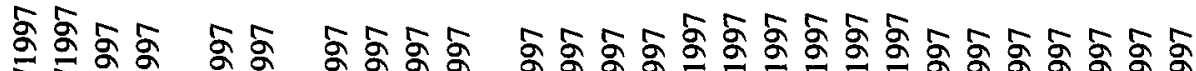
ดั

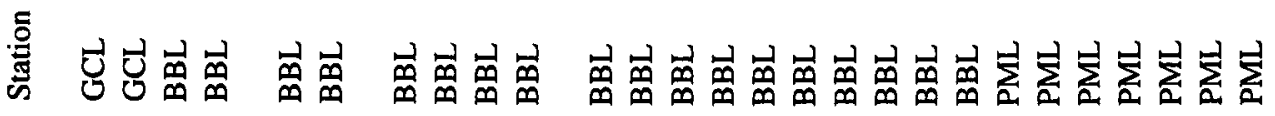

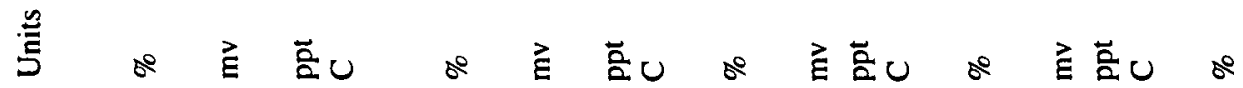

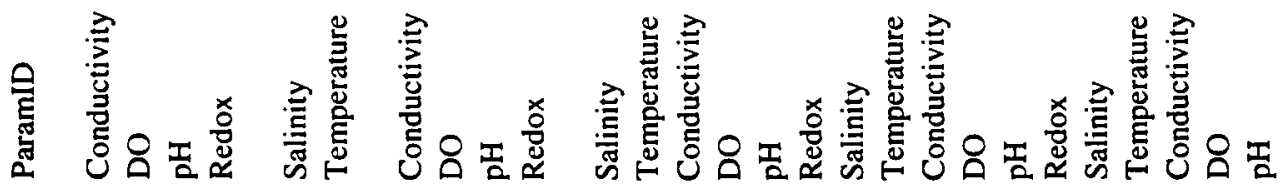

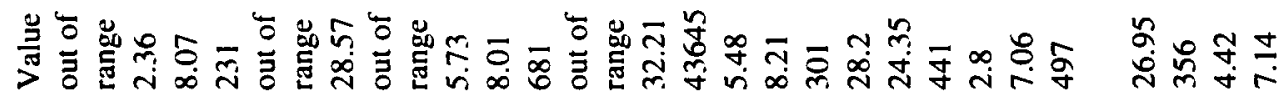

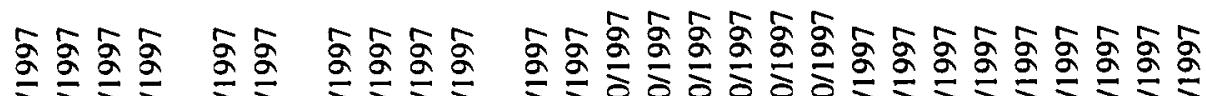

范

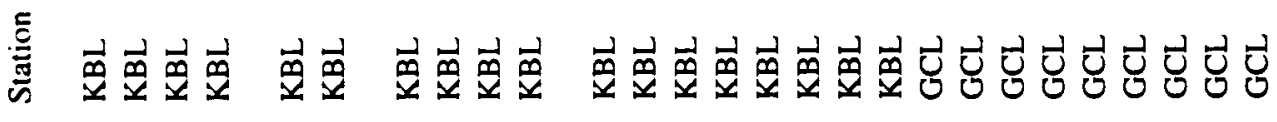




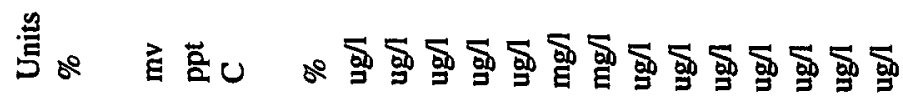

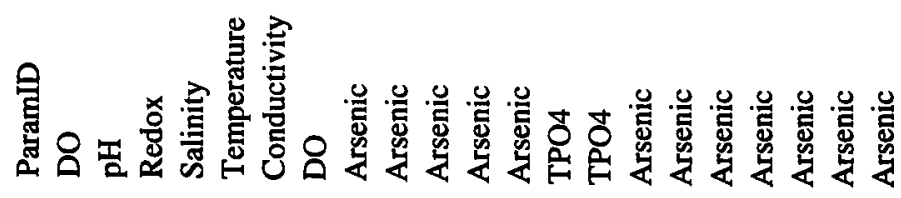

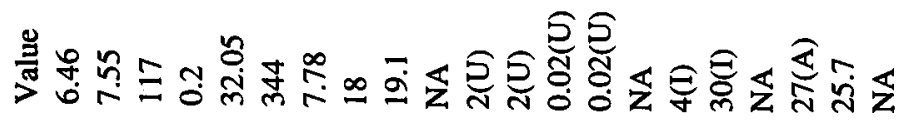

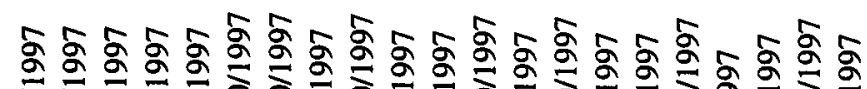

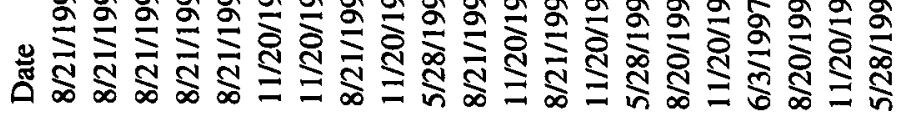

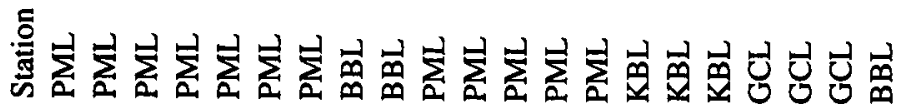

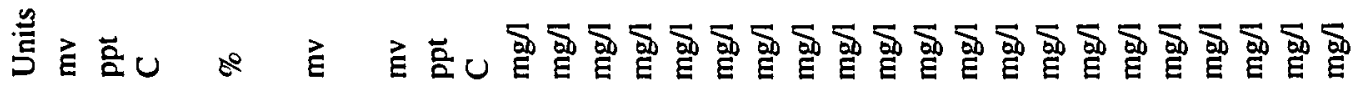

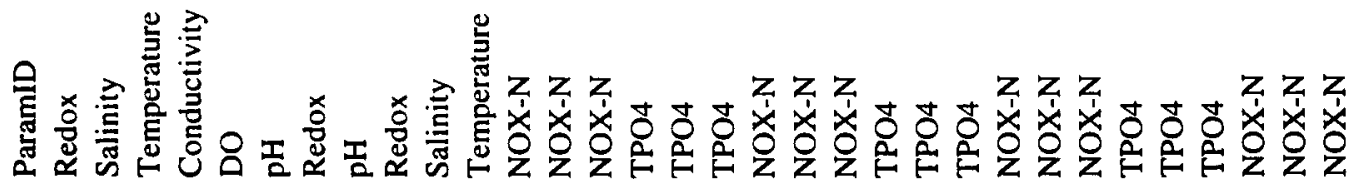

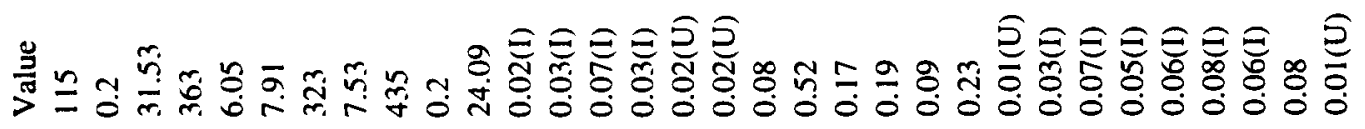

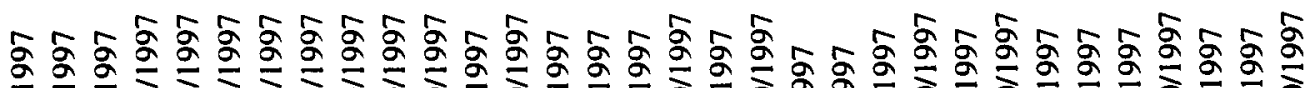

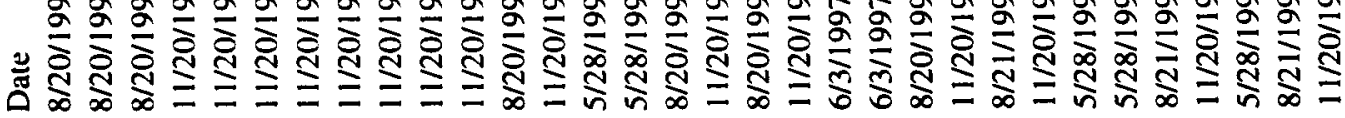

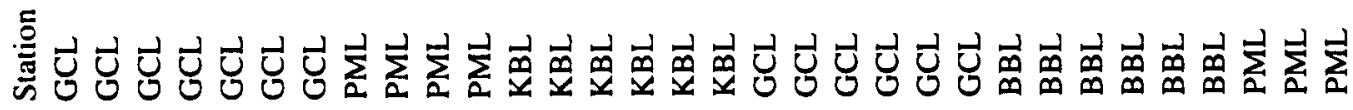




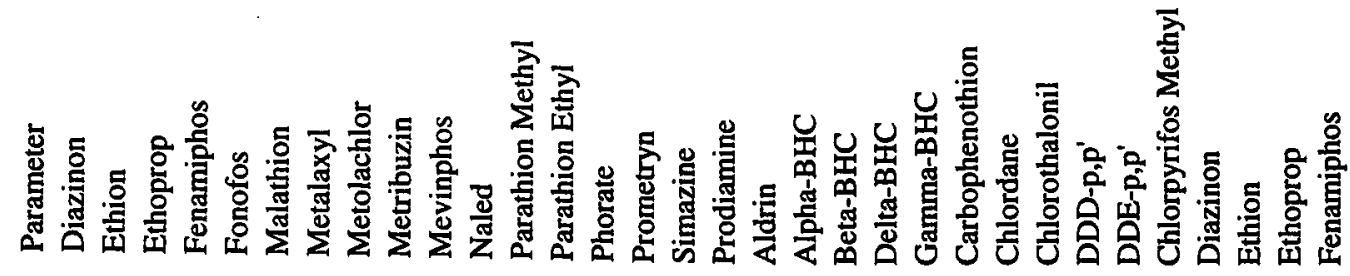

宊

光

8

สิ

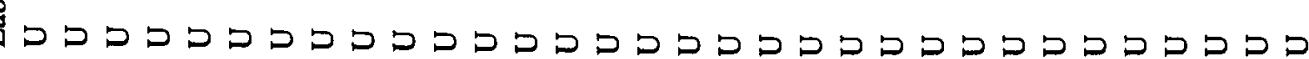

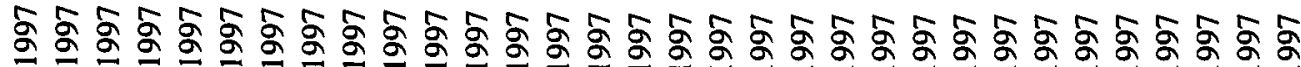

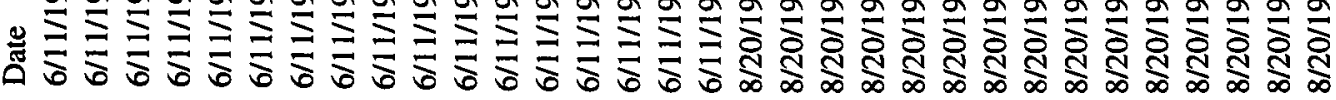

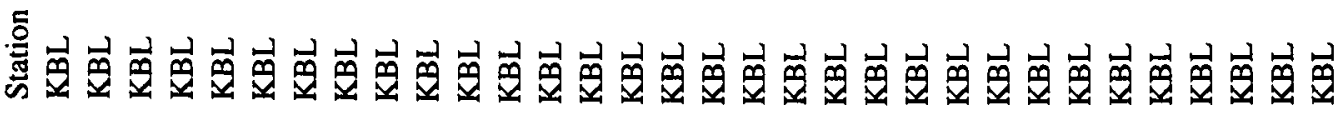

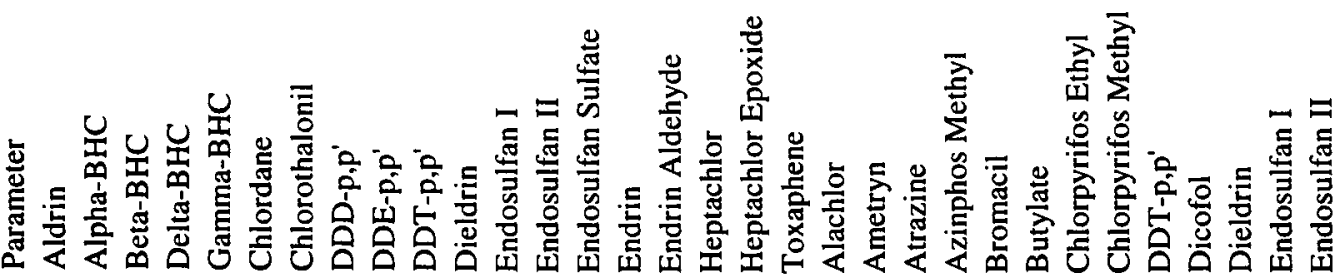

离

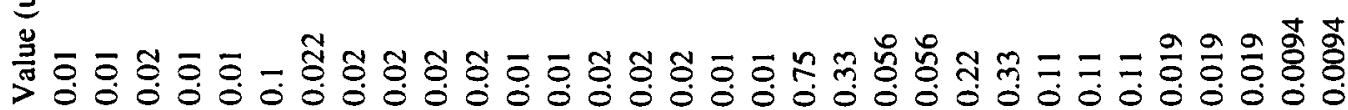

ஜัن

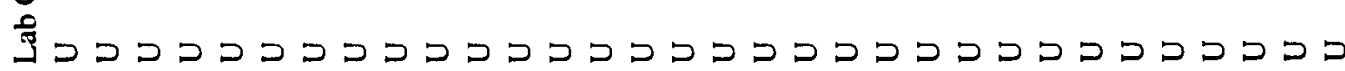

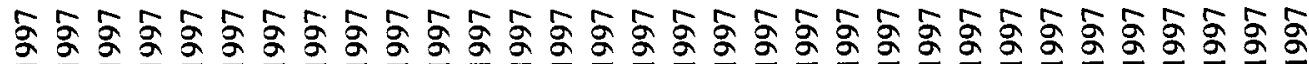

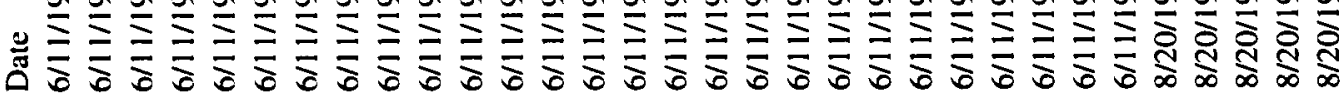

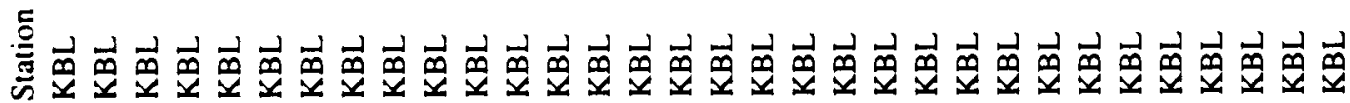




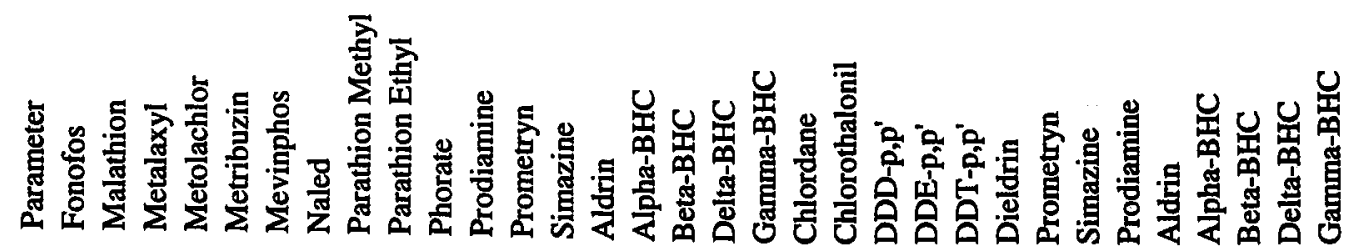

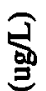

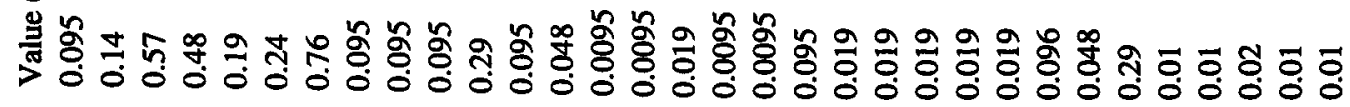

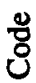

สิ

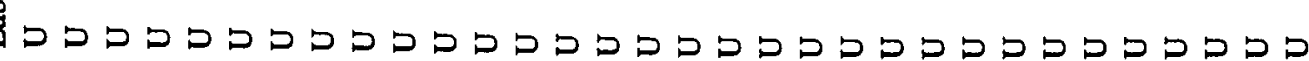

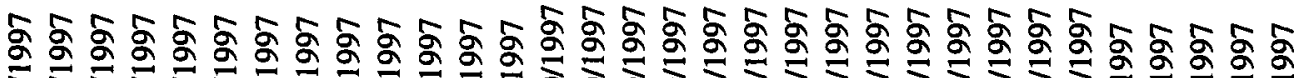

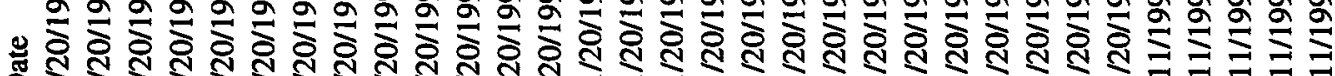
๑

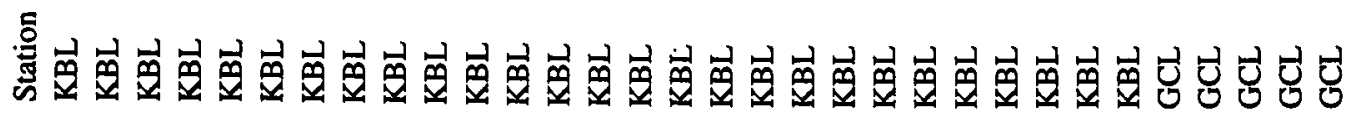

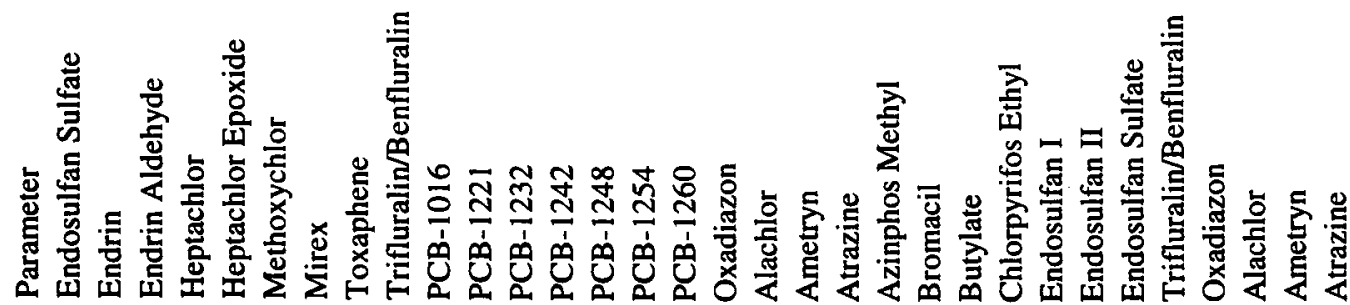
总

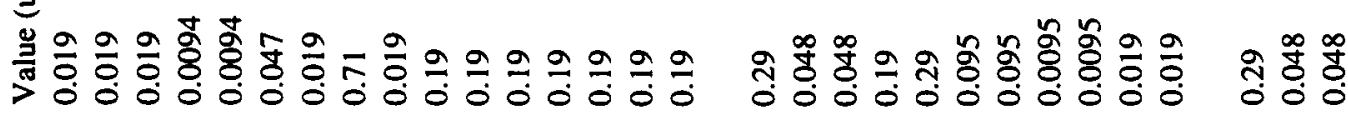
¿ัن

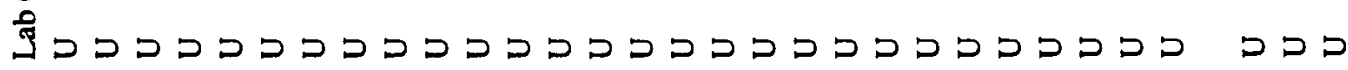
\% 0

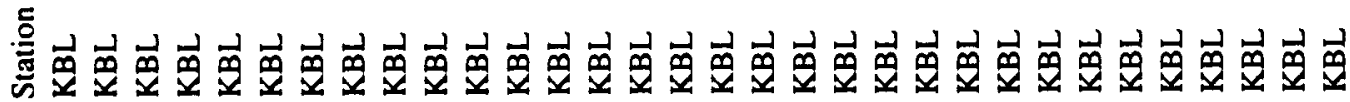




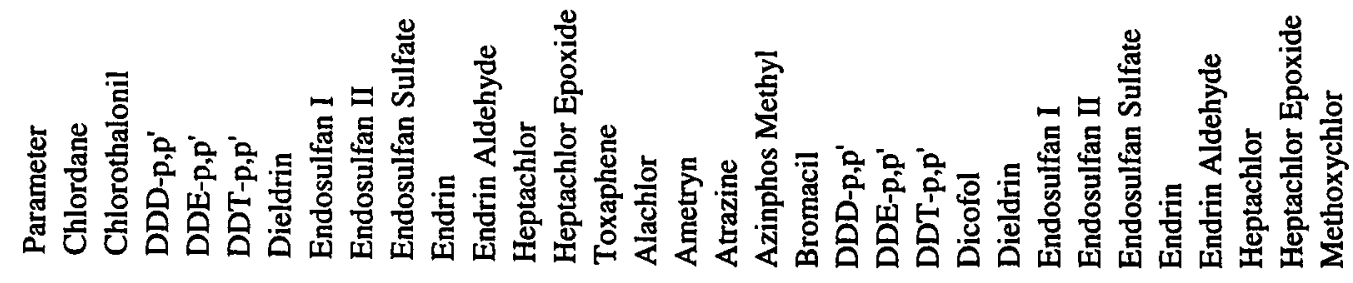

它

尝官

نั

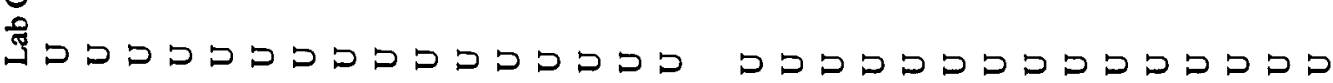

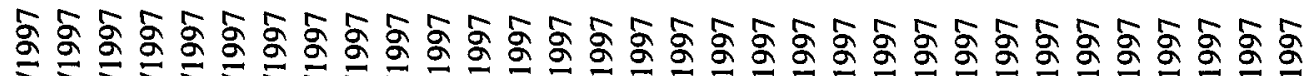

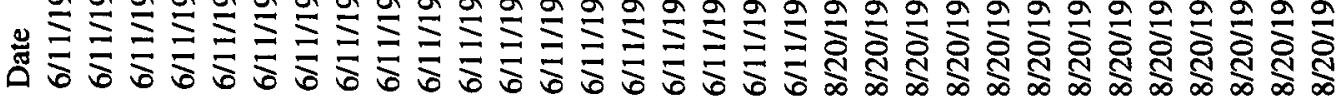

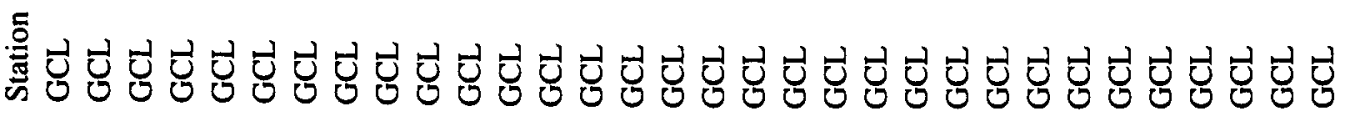

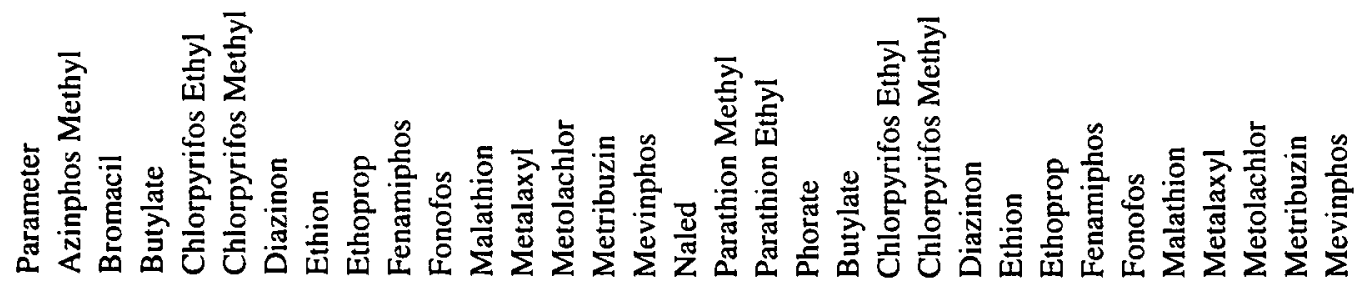

宊

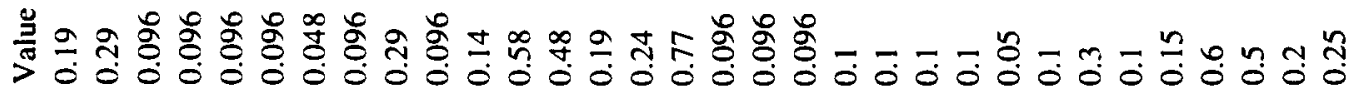

छั

苟 $\supset \supset \supset \supset \supset \supset \supset \supset \supset \supset \supset \supset \supset \supset \supset \supset \supset \supset \supset \supset \supset \supset \supset \supset \supset \supset \supset \supset \supset \supset \supset$

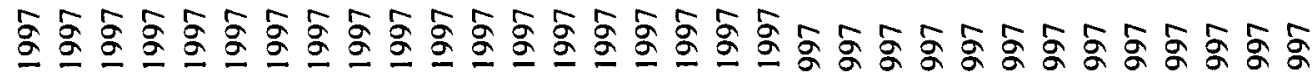

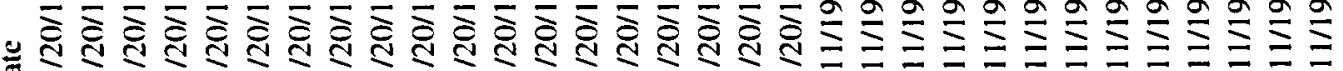

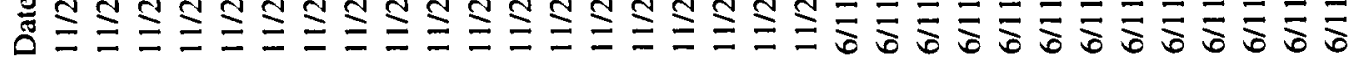

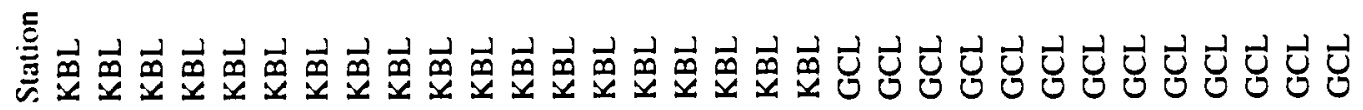




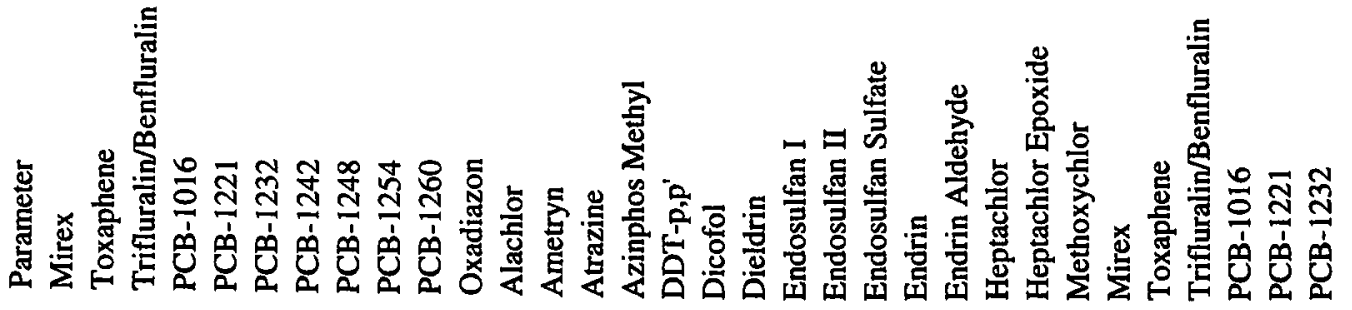

商

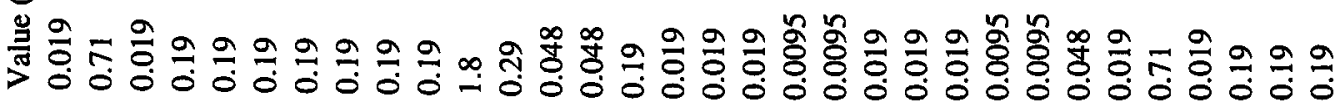

\&ัँ

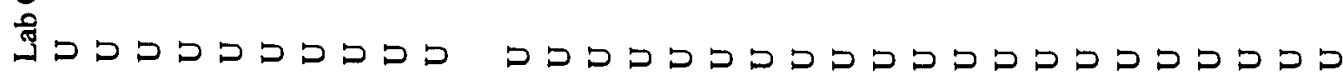

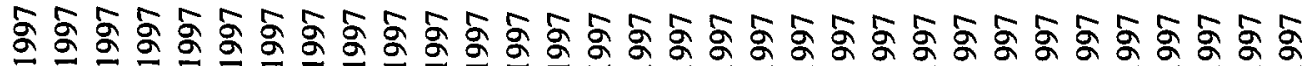

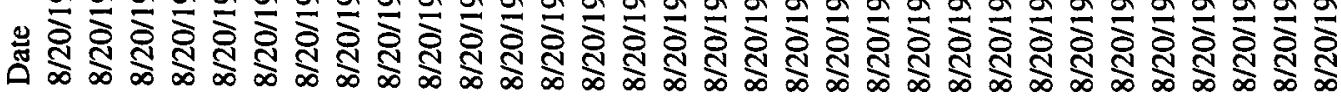

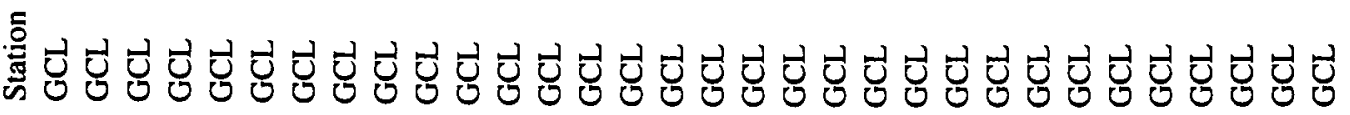

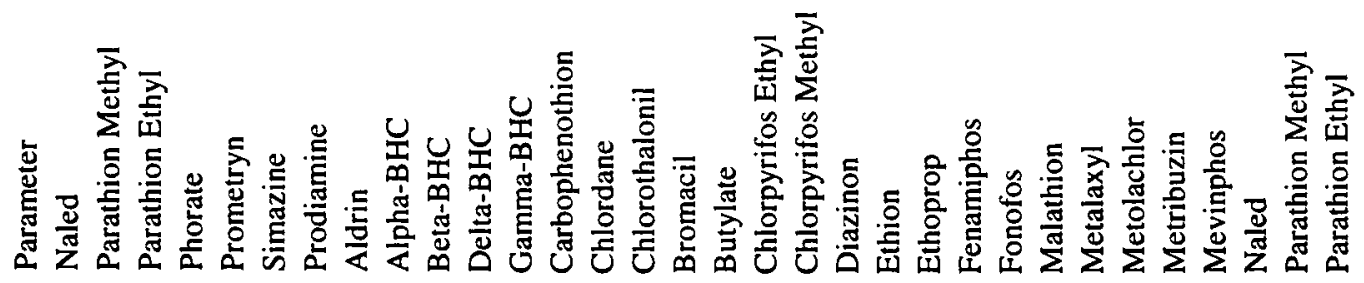

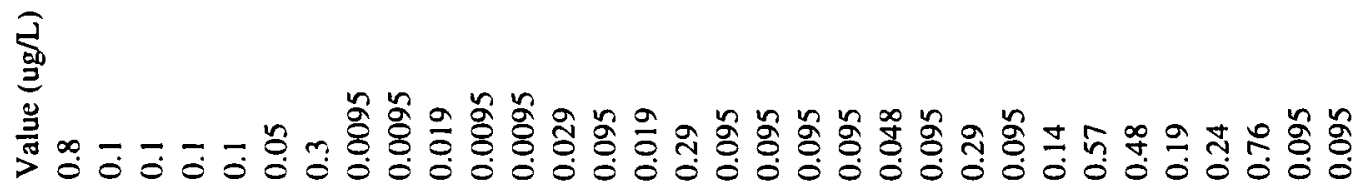

范

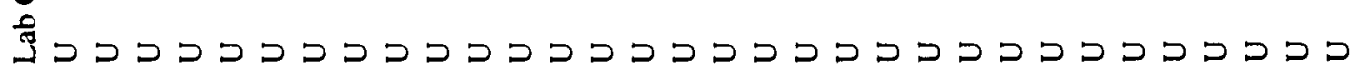

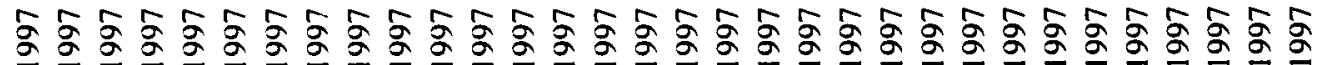

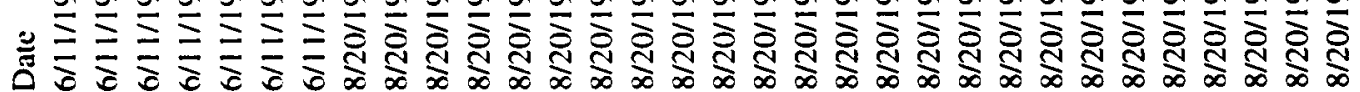

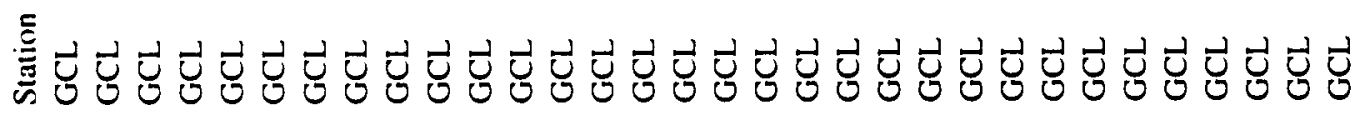




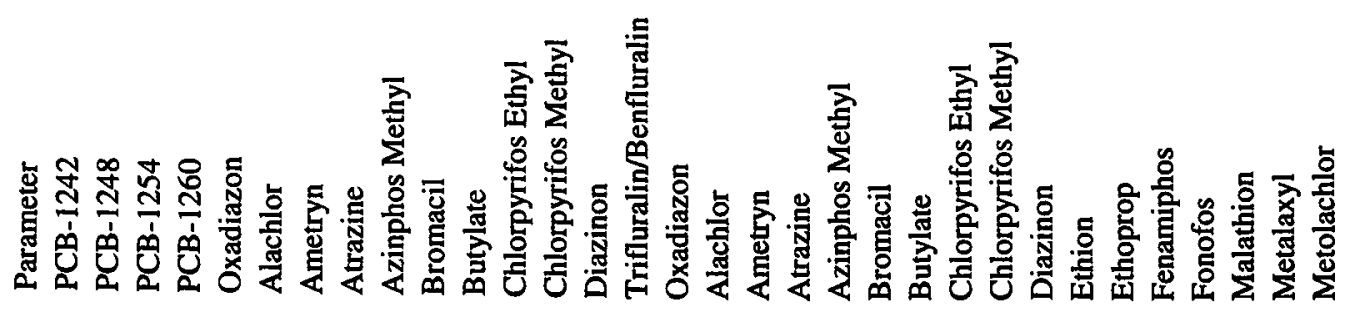

宊

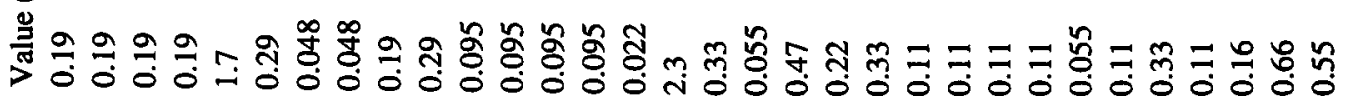

ठั

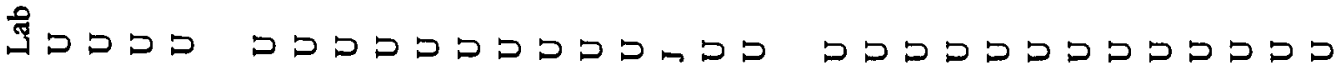

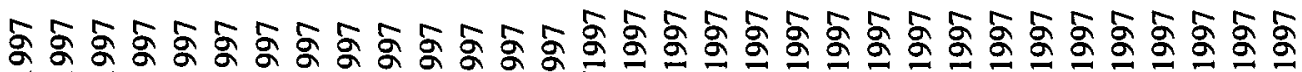

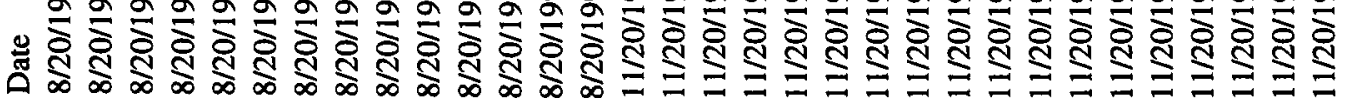

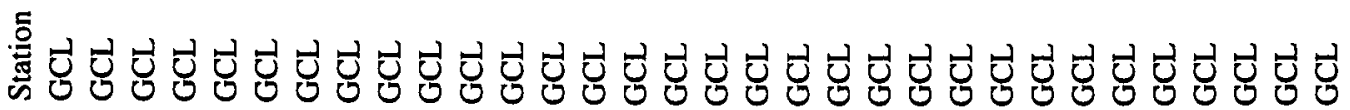

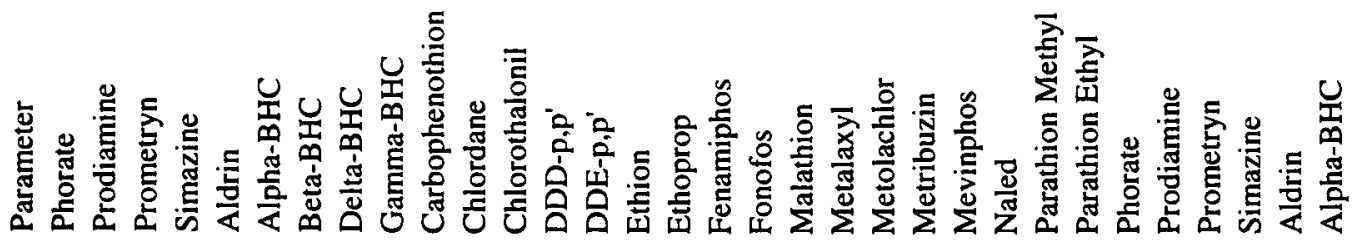

范

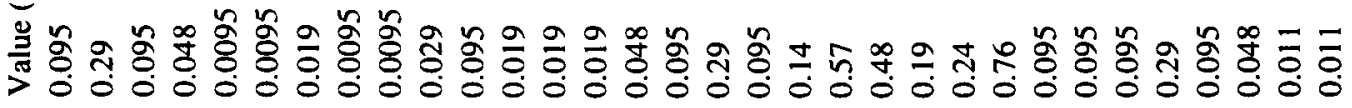

过

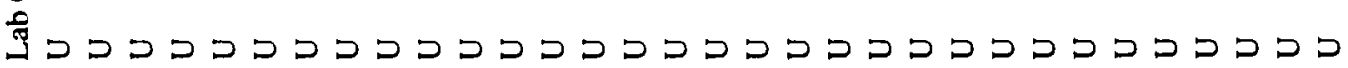

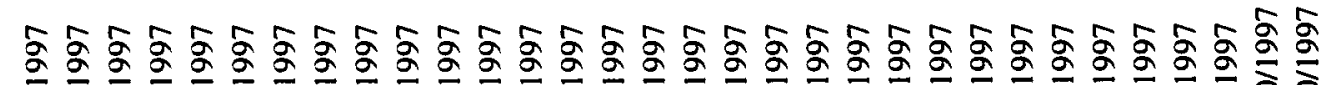

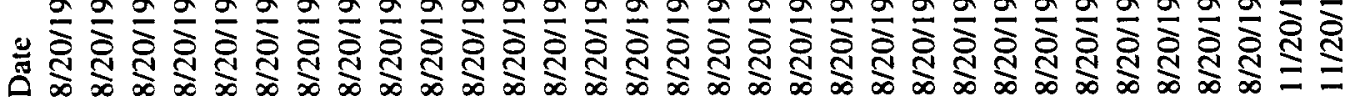

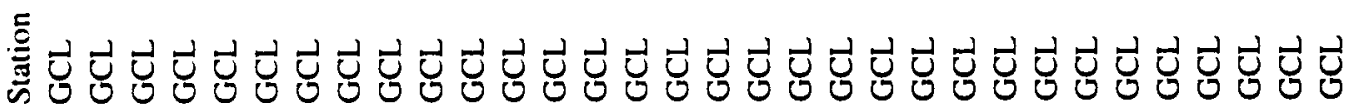




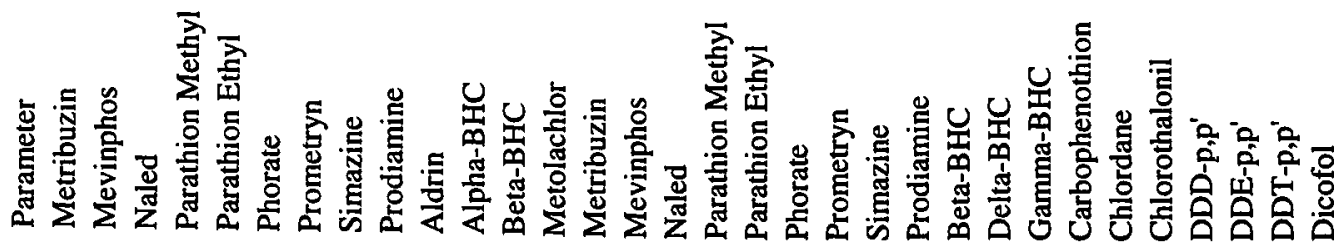

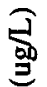

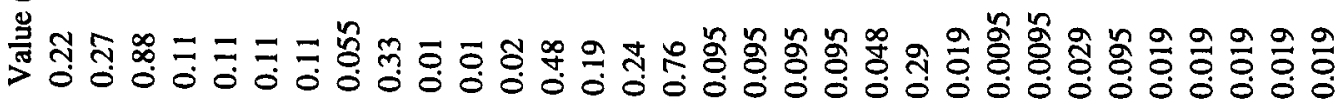

نे

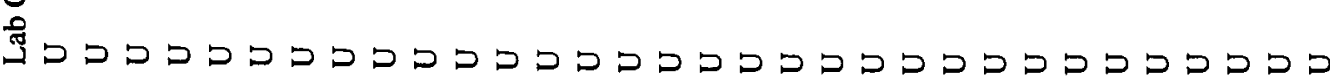

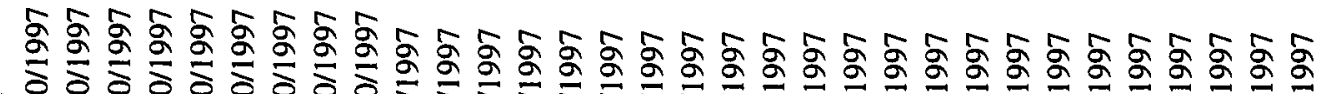

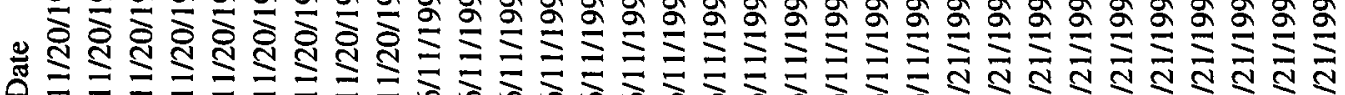

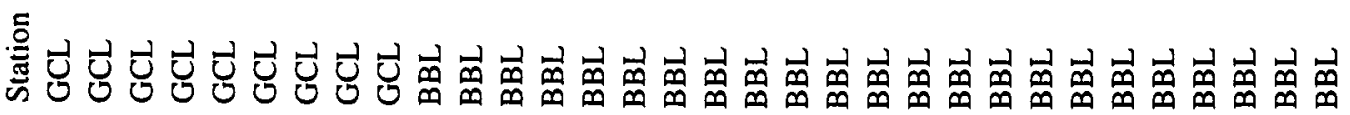

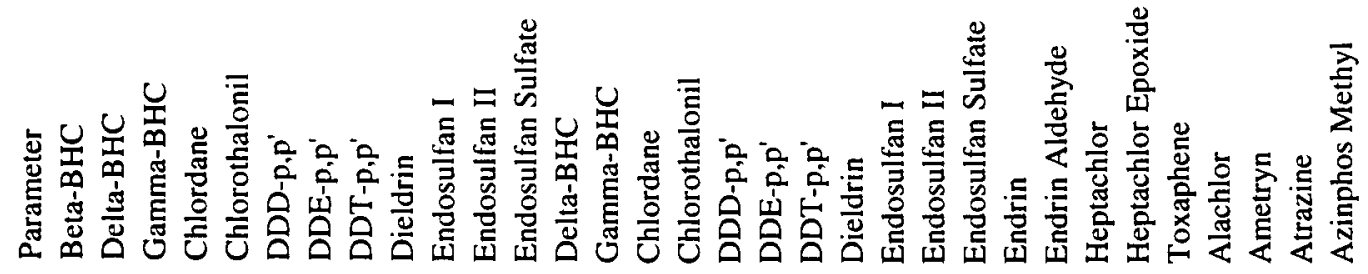

鄫

竞

$\stackrel{乛}{8}$

趈 $\supset \supset \supset \supset \supset \supset \supset \supset \supset \supset \supset \supset \supset \supset \supset \supset \supset \supset \supset \supset \supset \supset \supset \supset \supset \supset \supset \supset \supset \supset \vdash \supset$

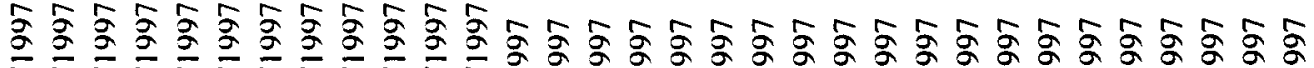

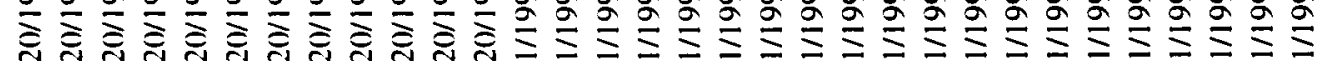

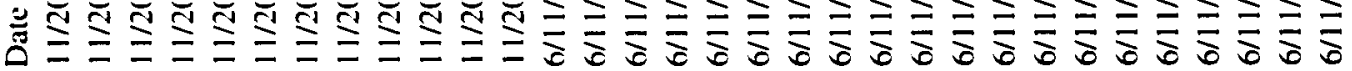

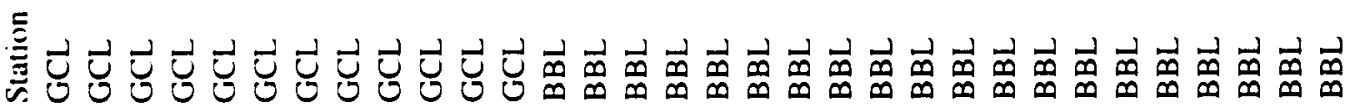




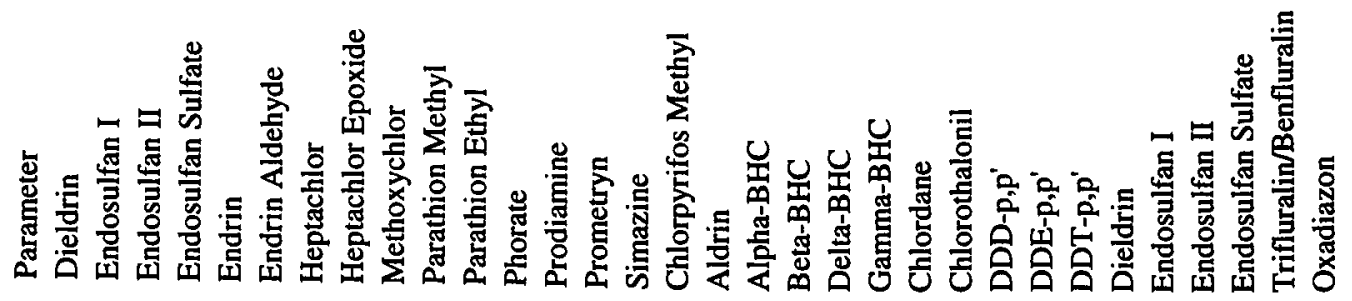

它

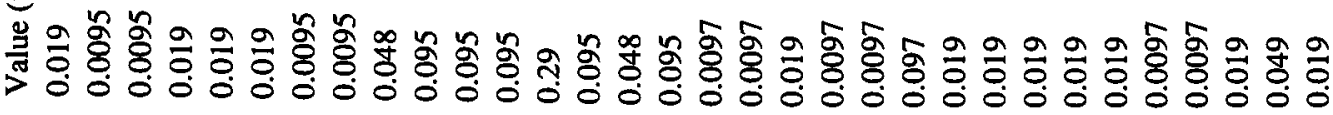

逭

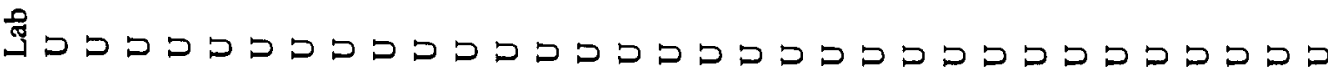

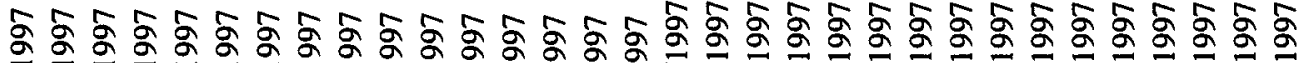

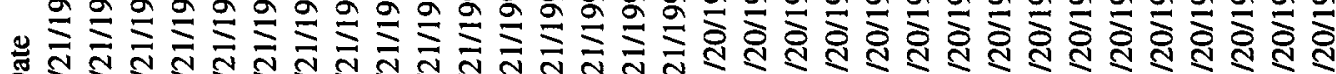
D্ণ

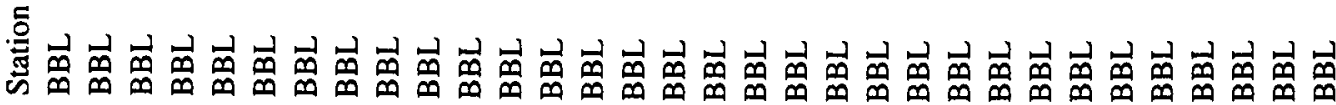

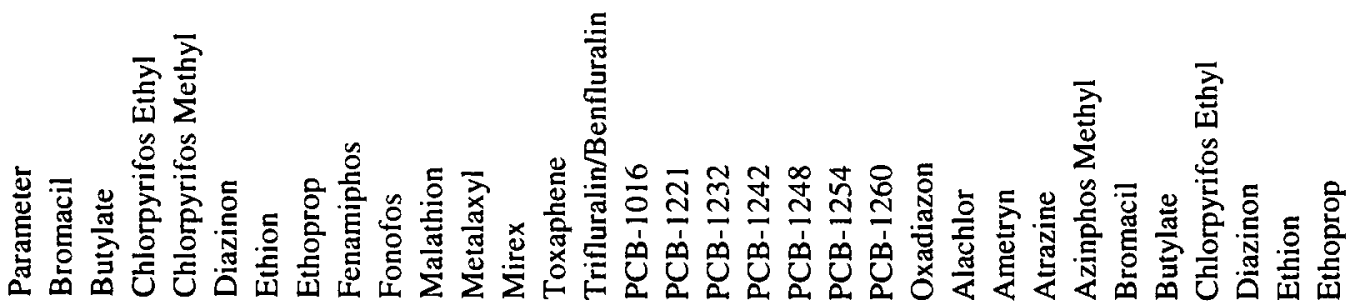

急

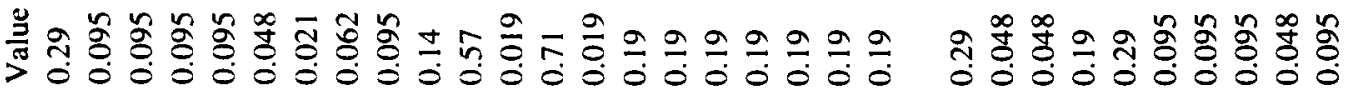

ปั

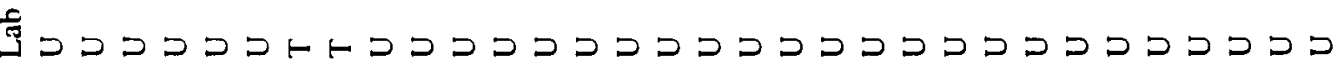

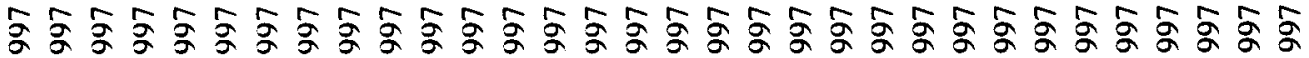
•

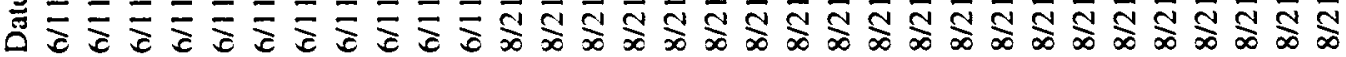

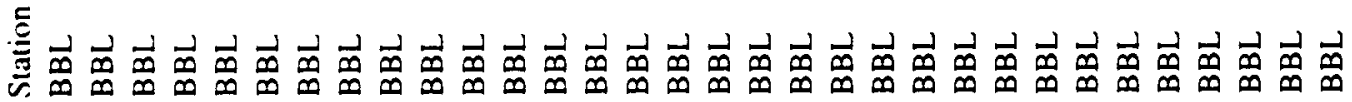




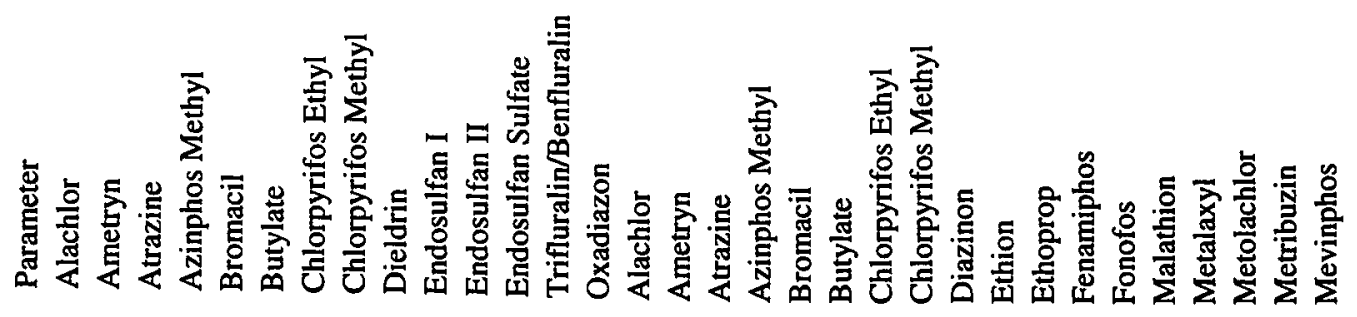

宊

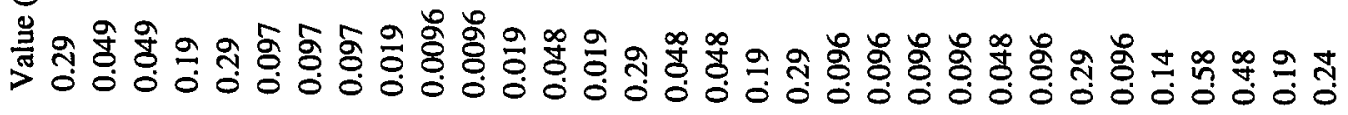

$\ddot{8}$

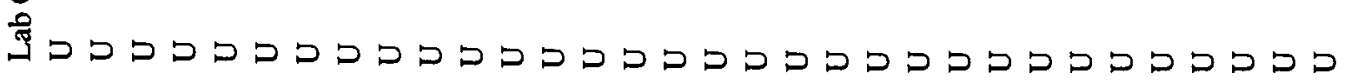

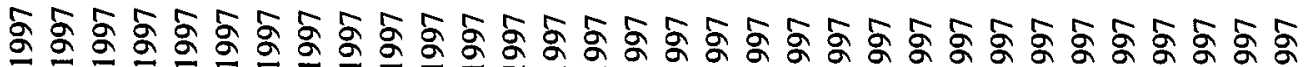
๘

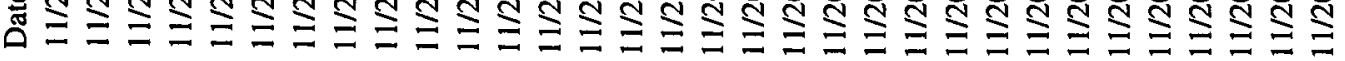

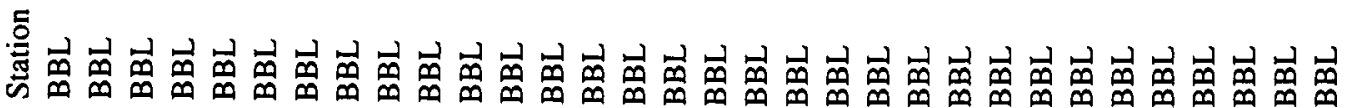

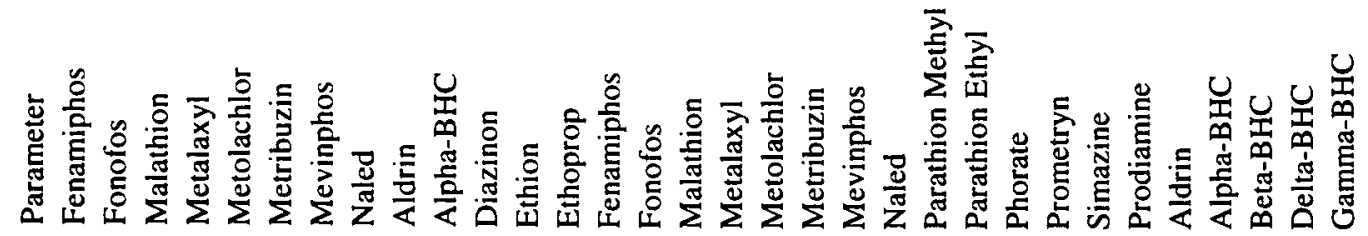

声

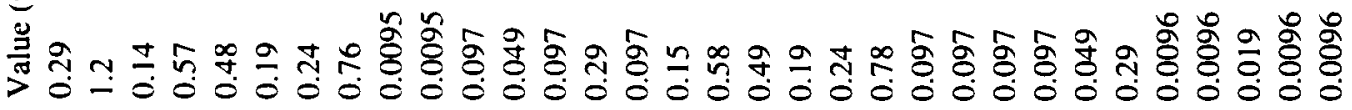

$\ddot{\varepsilon}$

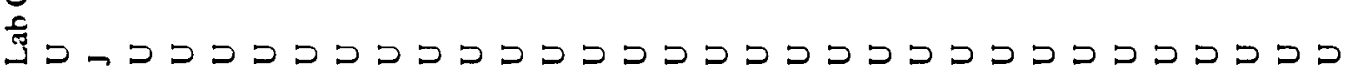

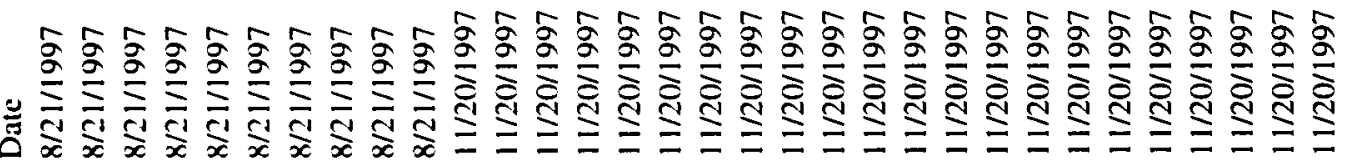

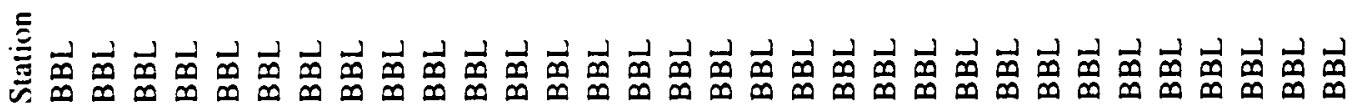




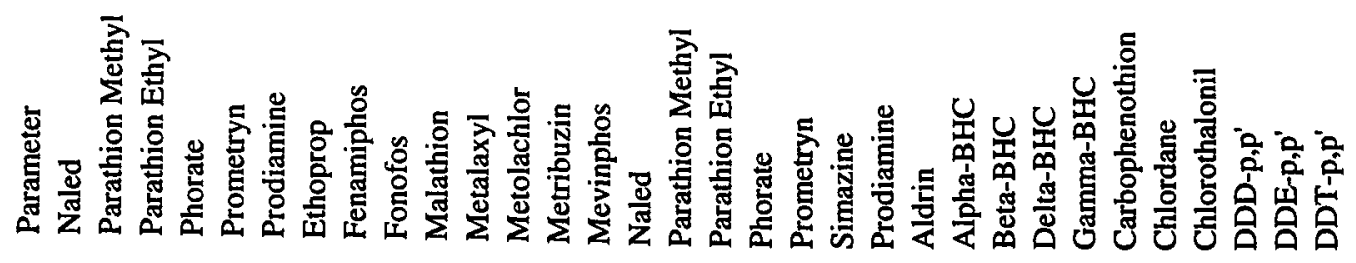

寉

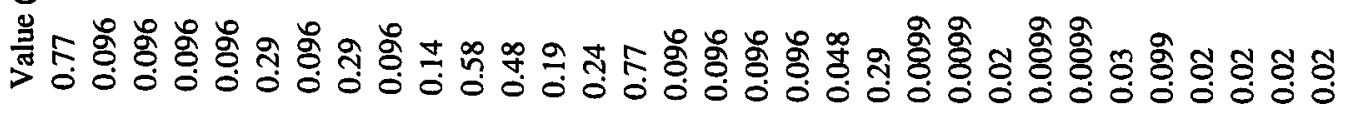

$\ddot{8}$

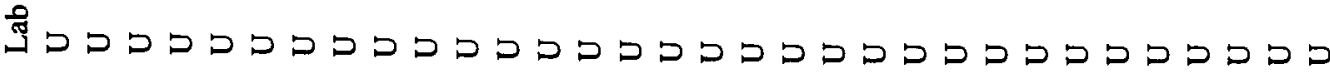

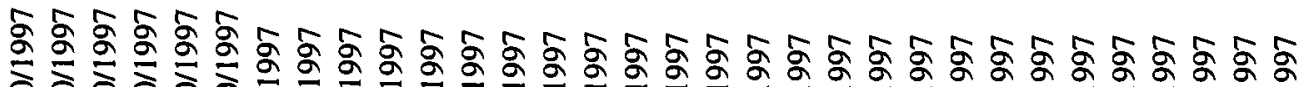

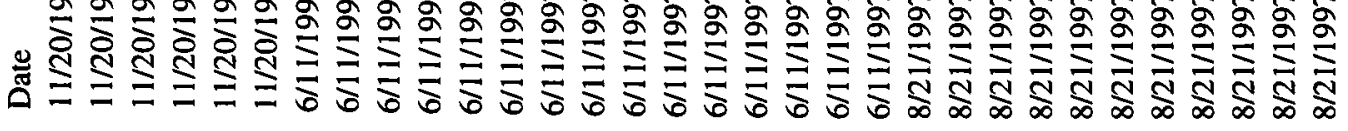

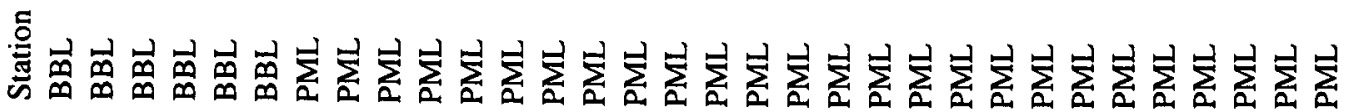

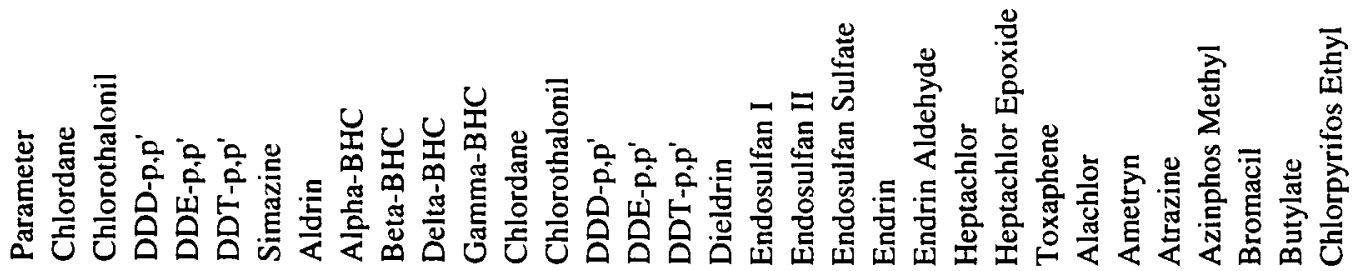

雪

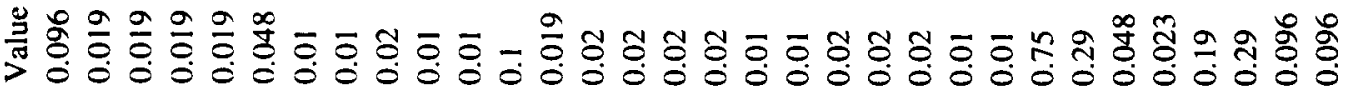

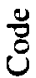

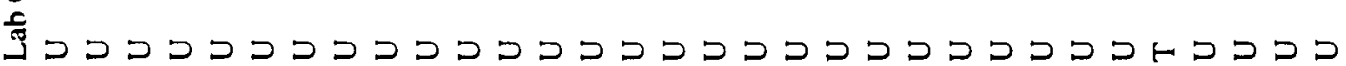

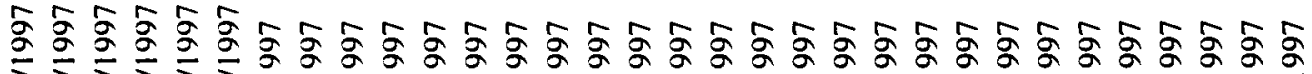

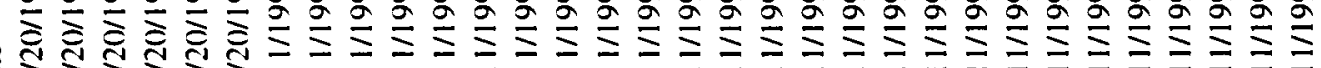

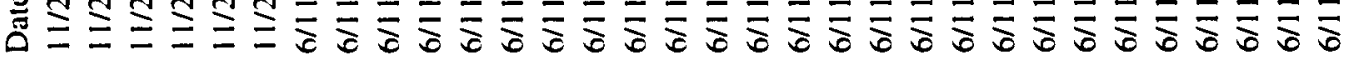

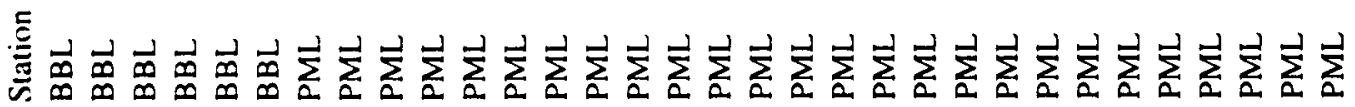




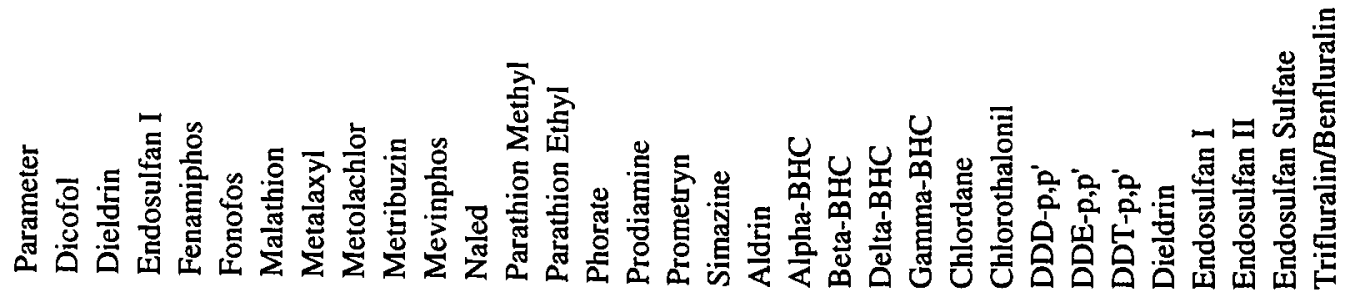

穴

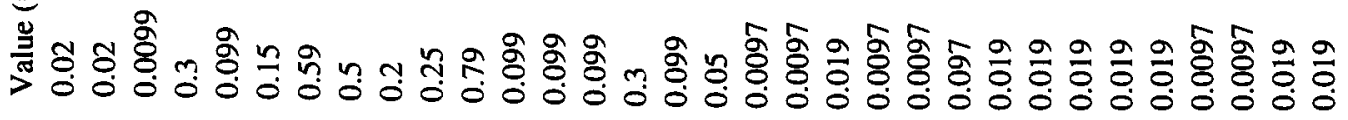

ن

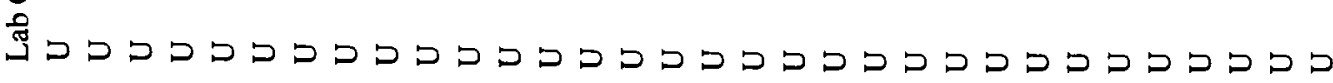

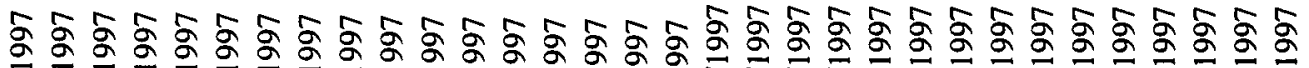
״

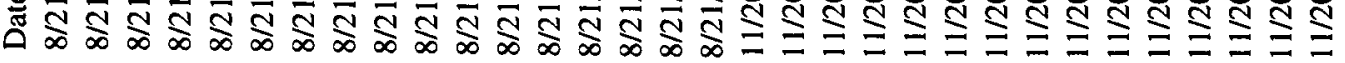

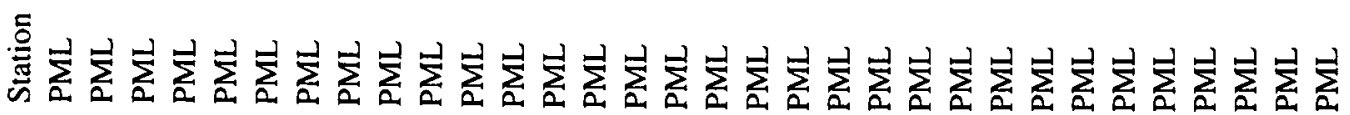

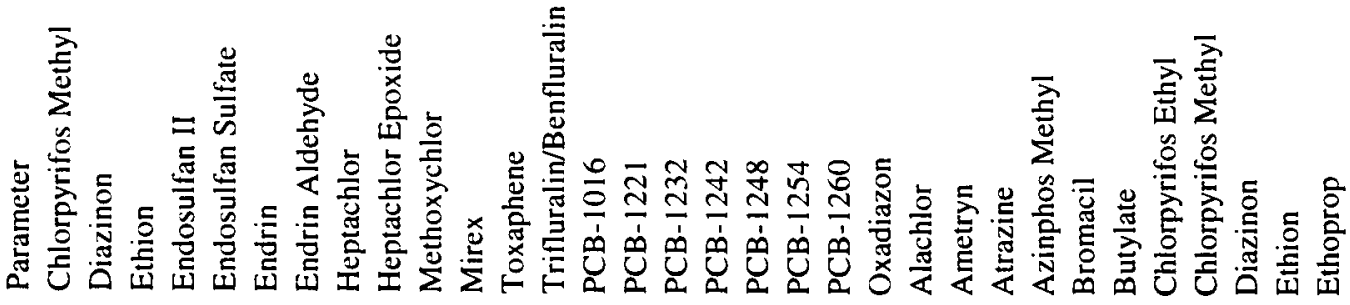

灵

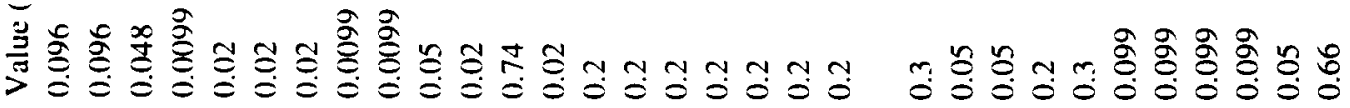

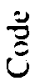

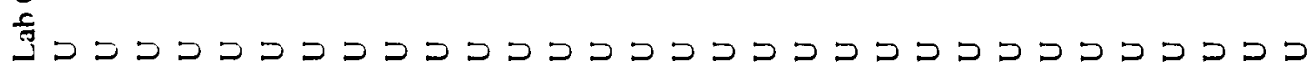

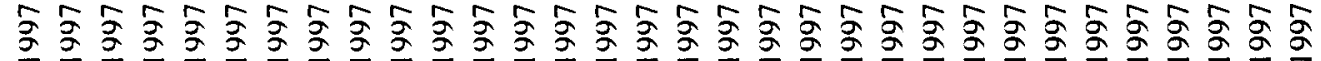

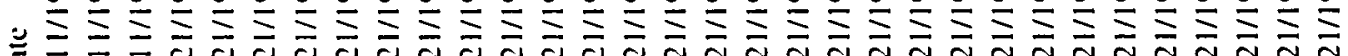

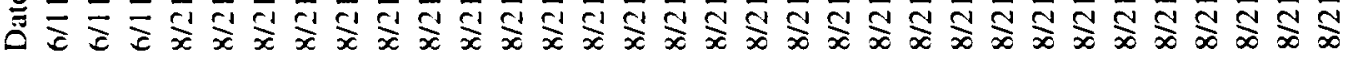

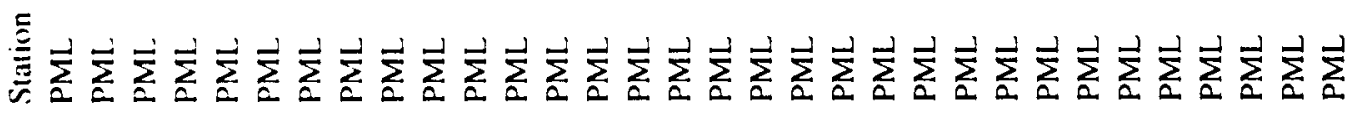




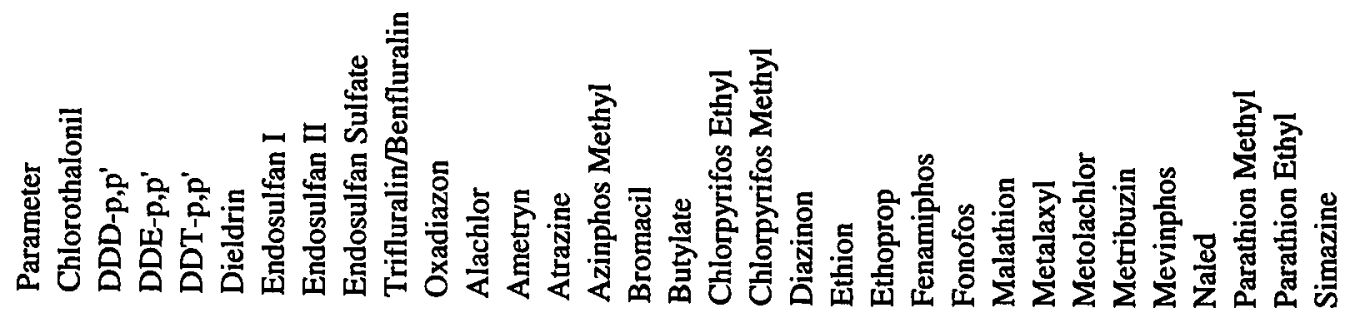

宓

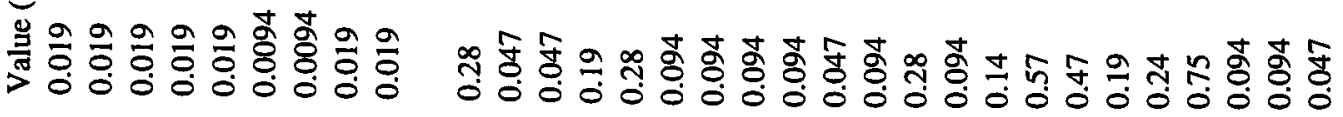

용

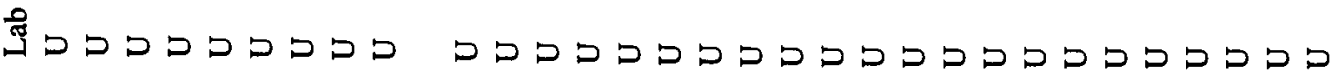

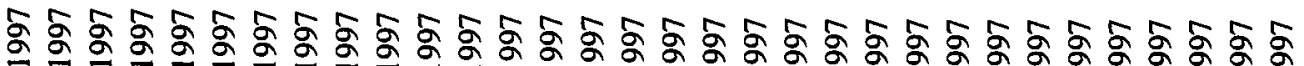
๑

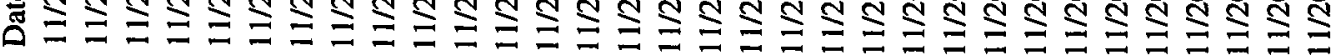

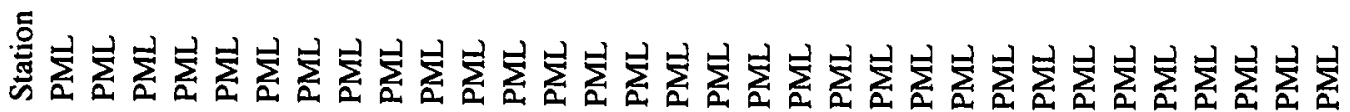

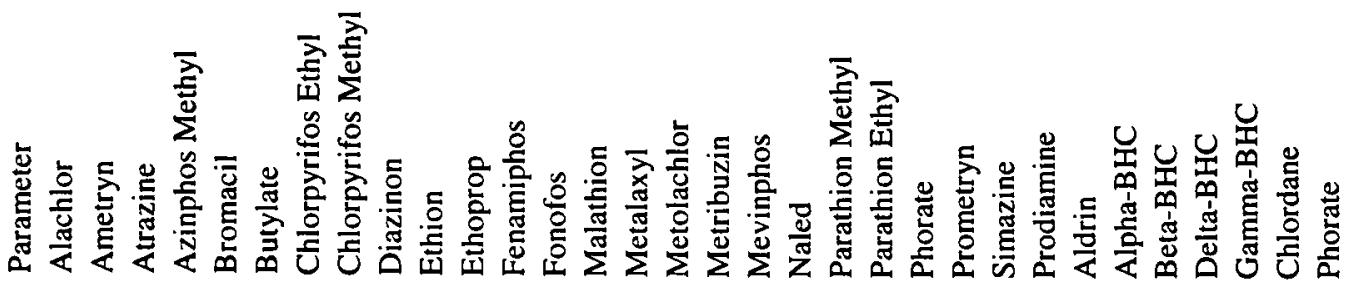

些

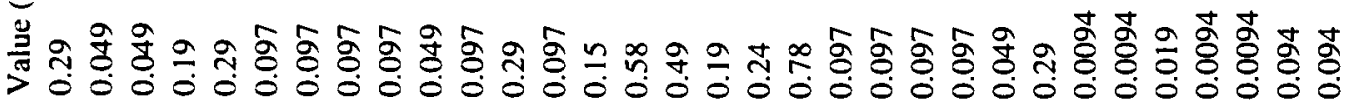

:

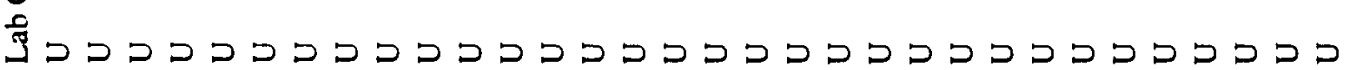

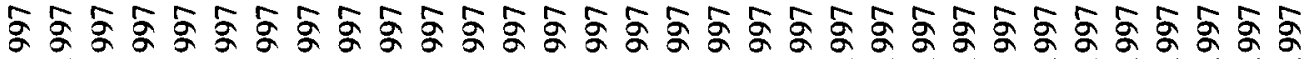

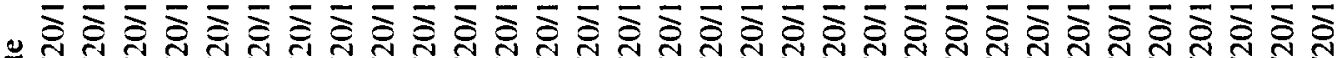

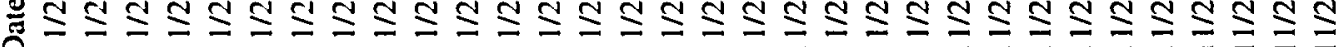

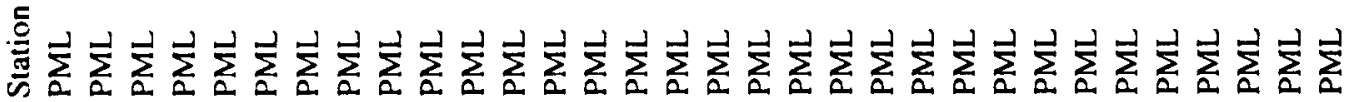




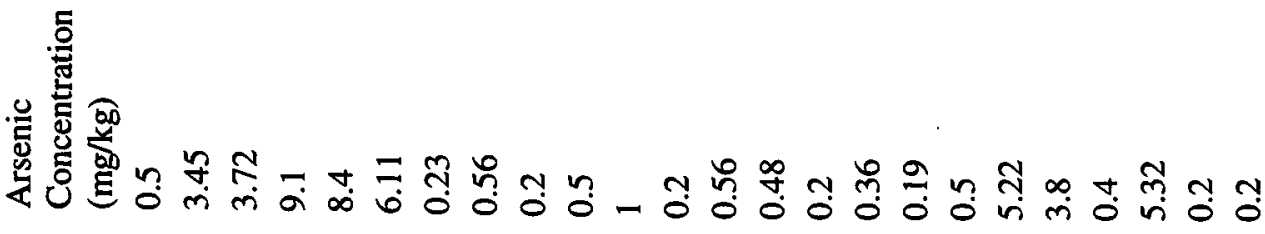

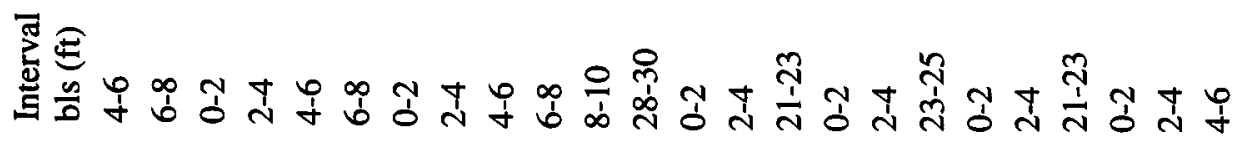

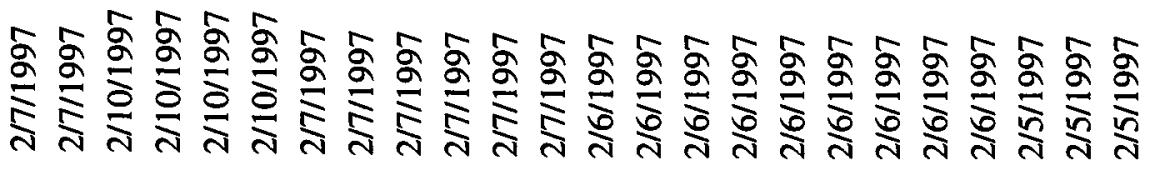

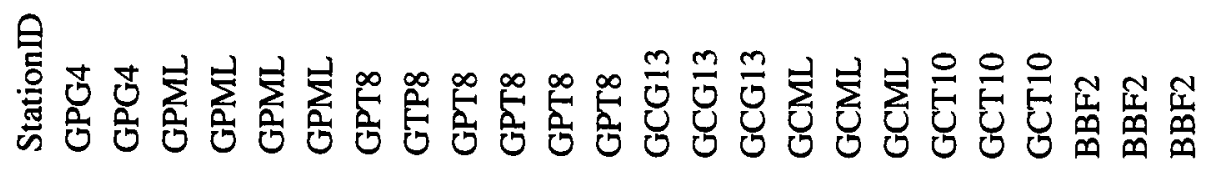

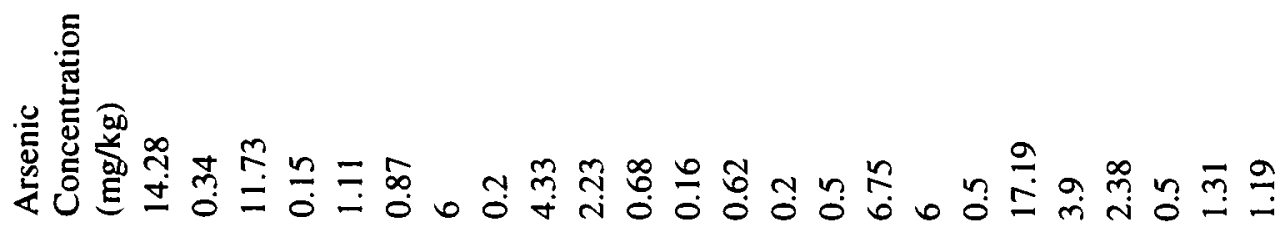

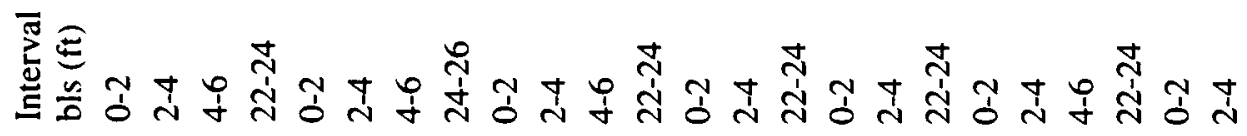

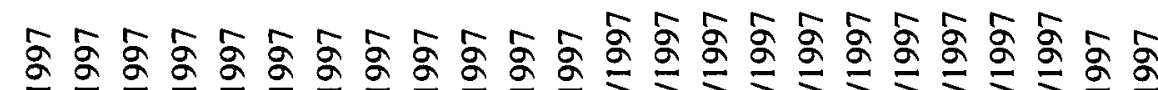

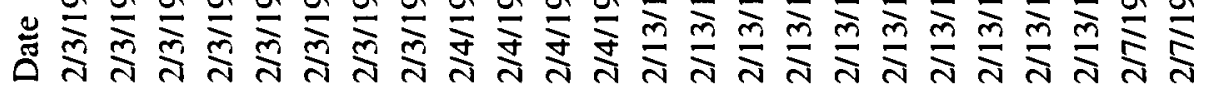

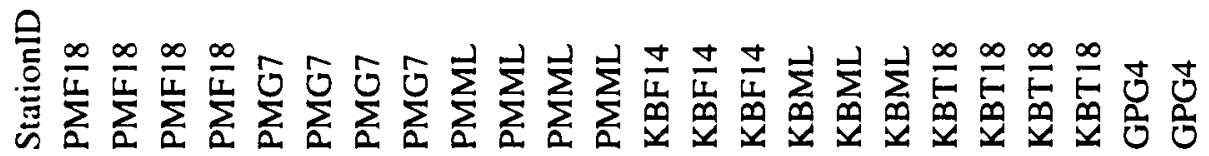




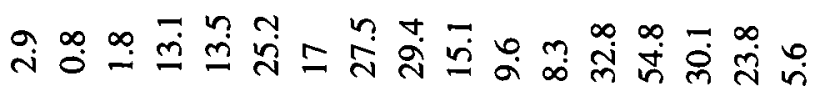

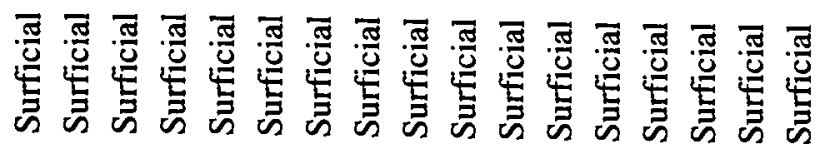

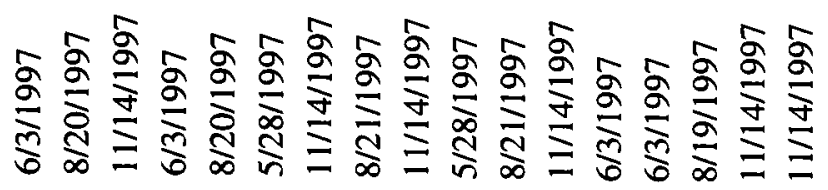

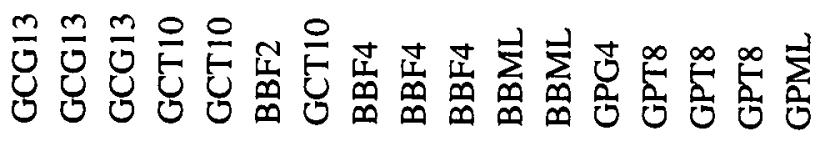

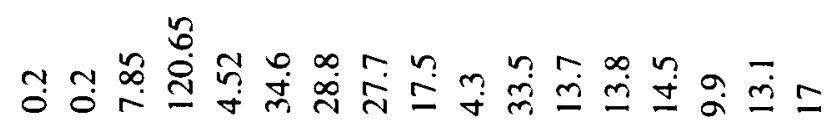

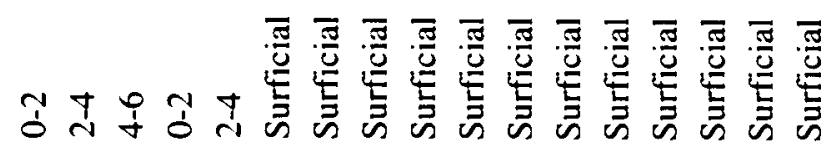

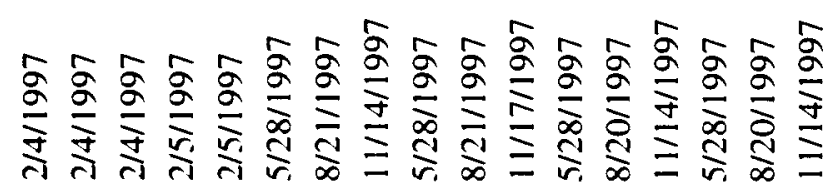

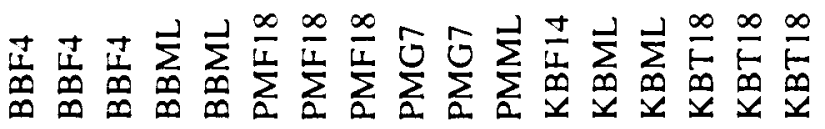

